UNIVERSIDADE DE SÃO PAULO - USP

TEREZA VIRGINIA MOUSINHO REIS

METODOLOGIA PARA ESTIMAR A LINHA DE BASE DE PROJETO MDL CONECTADO A SISTEMA ELÉTRICO: UMA ABORDAGEM PROSPECTIVA 
Tereza Virginia Mousinho Reis

\section{METODOLOGIA PARA ESTIMAR A LINHA DE BASE DE PROJETO MDL CONECTADO A SISTEMA ELÉTRICO: UMA ABORDAGEM PROSPECTIVA}

Tese apresentada à Escola Politécnica da Universidade de São Paulo para a obtenção do título de Doutora em Engenharia Elétrica 
Tereza Virginia Mousinho Reis

\section{METODOLOGIA PARA ESTIMAR A LINHA DE BASE DE PROJETO MDL CONECTADO A SISTEMA ELÉTRICO: UMA ABORDAGEM PROSPECTIVA}

Tese apresentada à Escola Politécnica da Universidade de São Paulo para a obtenção do título de Doutora em Engenharia Elétrica

Área de Concentração: Sistemas de Potência

Orientador:

Prof. Dr. Marco Antonio Saidel 
Este exemplar foi revisado e alterado em relação à versão original, sob responsabilidade única do autor e com a anuência de seu orientador.

São Paulo, de junho de 2009.

Assinatura do autor

Assinatura do orientador

FICHA CATALOGRÁFICA

Reis, Tereza Virginia Mousinho

Metodologia para estimar a linha de base de projeto MDL conectado a sistema elétrico: uma abordagem prospectiva /

T.V.M. Reis -- ed.rev. -- São Paulo, 2009.

$258 \mathrm{p}$.

Tese (Doutorado) - Escola Politécnica da Universidade de São Paulo. Departamento de Engenharia de Energia e Automação Elétricas.

1. Gases (Emissão; Efeitos adversos) 2. Efeito estufa 3. Sistemas elétricos I. Universidade de São Paulo. Escola Politécnica. Departamento de Engenharia de Energia e Automação Elétricãs II. t. 


\section{DEDICATÓRIA}

A meu pai 


\section{AGRADECIMENTOS}

Ao professor Marco Antônio Saidel pela orientação e pelo estímulo pela confiança e pelo privilégio de contar com as suas análises e sugestões transmitidas durante todo o trabalho.

Aos professores Osvaldo Soliano e Fernando Almeida Prado pelas análises críticas e sugestões criativas que foram fundamentais para o aprimoramento desta pesquisa.

Ao professor Adilson de Oliveira pela enorme generosidade e espírito acadêmico que demonstrou ao colocar à disposição deste trabalho parte das pesquisas desenvolvidas sob a sua coordenação relacionadas com a modelagem e simulação do despacho hidrotérmico do sistema interligado nacional (SIN).

Ao querido amigo e colega Felipe cuja participação foi absolutamente fundamental para a adaptação e aplicação do modelo de equilíbrio integrado aos propósitos desta pesquisa.

A Neide e Renata pelo apoio que deram na execução deste trabalho.

A Vivina, querida amiga, cuja coragem e espírito de luta serviram como inspiração e exemplo de superação para a realização desta pesquisa.

A Laura, companheira de tantas batalhas em favor da elevação da participação das fontes alternativas de energia na matriz do setor elétrico nacional.

A Adriana, minha irmã, e a Diego, pelas inúmeras manifestações de carinho e amizade manifestadas que muito ajudaram para a conclusão deste trabalho.

A Cláudia, minha irmã e amiga, por tudo que representa para mim como exemplo de sabedoria, dedicação, inteligência, coragem e solidariedade.

Ao querido companheiro Cláudio e aos meus filhos Mino, Lauro e Cacau, pela força, cuidado e incentivo que passaram ao longo do período de realização deste trabalho. 


\section{RESUMO}

REIS, Tereza Virgínia Mousinho. Metodologia para Estimar o Fator de Substituição de Projeto MDL Conectado a Sistema Elétrico: Uma Abordagem Prospectiva. Tese (Doutorado) Escola Politécnica, Universidade de São Paulo, São Paulo, 2009.

Essa pesquisa tem como objetivo propor um novo referencial metodológico para estimar a linha de base para projetos de MDL a serem conectados ao sistema interligado nacional - SIN, a partir de uma visão do mix futuro das fontes energéticas que serão responsáveis pelas gerações de energia, nos próximos dez anos. Objetiva também aplicar essa nova abordagem para calcular as emissões deslocadas pelas atividades de projetos de MDL, através do cálculo do fator de substituição, medido em $\mathrm{tCO}_{2} / \mathrm{MWh}$. Este fator estima a redução das emissões decorrente da substituição de parte da energia gerada pelas usinas térmicas convencionais, pela entrada no sistema de usinas que geram energia limpa e/ou pela redução da demanda agregada do sistema elétrico pela implementação de programas/medidas de eficiência energética pelo lado da demanda

Para tanto, usando um modelo que simula o equilíbrio entre a oferta elétrica e os requisitos de energia previstos para o horizonte de 10 anos de energia calcula-se, inicialmente, as emissões dos GEE do sistema elétrico sem considerar a entrada do projeto de MDL. Na seqüência, as emissões do sistema elétrico são novamente calculadas, considerando a entrada do projeto MDL.

Atualmente a linha de base do SIN é calculada, mensalmente, com base no Tool to calculate the emission factor for an eletricity system, que é uma ferramenta metodológica aprovada pelo CE do MDL, para determinar o fator de emissão de sistemas elétricos interligados. Essa ferramenta determina o fator 
de emissão de atividades de projetos que substituem eletricidade gerada na rede elétrica.

Sustenta-se nesta pesquisa que é pouco provável, pelo menos no SIN, que as condições observadas em anos recentes e/ou atuais se reproduzam no futuro. Ao contrário do que ocorria até poucos anos atrás, em que a expansão do sistema elétrico era basicamente assentada em empreendimentos hidrelétricos, na atualidade desenha-se uma clara tendência à fossilização da matriz do setor elétrico nacional.

Os resultados do trabalho mostraram que há uma tendência de elevação das emissões do SIN, embora o comportamento do Fator de Substituição, em termos anuais apresente variações importantes, em função das reais necessidades do despacho das térmicas inflexíveis que servem ao SIN a cada ano. No entanto, considerando todo o período estudado, os resultados encontrados são coerentes com o aumento da participação das UTE emissoras dos GEE no mix futuro das fontes energéticas que fornecerão eletricidade ao SIN. Os valores obtidos dos fatores de substituição ( SS $_{\text {SINp }}$ ) para todos os experimentos, entre 2008 e 2017, são significativamente superiores à linha de base do SIN de 2007, calculada com base no Tool to calculate the emission factor for an electricity system.

Palavras - chave: Linha de Base, Mecanismo de Desenvolvimento Limpo, Fator de Substituição, Emissões dos Gases de Efeito Estufa, Geração de Energia 


\section{ABSTRACT}

\section{REIS, Tereza V. M. Methodology to Estimate the Baseline Emissions by a}

Grid Connected CDM Project Activity: a forecasting approach. Thesis (Doctoral) Escola Politécnica, Universidade de São Paulo, São Paulo, 2009.

This research has as a goal propose a new methodological reference to assess the baseline for CDM projects designed to be connected to the national connected system - SIN, coming from a foreseen sight of the energetic sources mix that will be responsible for the energy generation, in the next ten years and apply the news approach to calculate the emissions move to distinct amounts of entry energies of SIN, either by generation of new plants that do not generate emissions of GHE, except concern nuclear plants, or by the reduction of future demand of electrical energy, originated from the implantation of programs/measures of energetic efficiency considering demand. The factor of emission replacement factor of the electrical system measures the energy movement generated by the plants that serve the electrical system by the entrance of new plants that do not generate emissions of GHE.

Thus, using a model that simulates the balance between supply and requirements for electric energy provided to the horizon of 10 years of energy it is estimated, initially, the GHG emissions of the electric system without considering the input of the CDM project. Following the emissions of the electric system are again calculated, considering the entry of the CDM project.

Currently, the SIN baseline is calculated, monthly as a base tool to calculate the emission factor for an electricity system, which is a methodological tool approved by the CDM Executive Board, to determine emission factor of electrical systems.

This thesis sustains that it is unlikely, at last in the SIN that the conditions noticed in recent years and/or conditions, will reproduce in the future. On the contrary of 
what has occurred a few years ago, in which the expansion of the electrical system was basically set up in hydro electrical enterprise, nowadays there is a trend toward fossilization of matrix of national electrical sector.

The results of the study showed that there is a trend of increased emissions of SIN, but behavior of Factor Substitution in the year, vary in important ways, depending on the needs of the order of thermal inflexible to serve the SIN each year. However, considering the whole period studied, the results are consistent with the increased participation of the GHG emission UTEs in future mix of energy sources that will provide electricity to the SIN. The values of the factors of substitution $\left(\mathrm{FS}_{\mathrm{SINp}}\right)$ for all experiments, between 2008 and 2017 are significantly above the baseline of SIN, 2007, calculated on the Tool do calculate the emission factor for an electricity system.

Keywords: Baseline, Clean Development Mechanism, Factor of Emission Replacement, Emissions the Greenhouse Gases, Energy Generation 


\section{LISTA DE ILUSTRAÇÕES}

Figura 1 Principais impactos em função do aumento da temperatura média global.................................................................... 58

Figura 2 Potencial de mitigação por região e por setor ......................... 67

Figura 3 Reduções cumulativas de emissões estimadas por tipo de projeto em quatro modelos

Figura $4 \quad$ Estrutura e Fluxograma do MEl.......................................... 118

Figura $5 \quad$ Mapa do Sistema de Transmissão (2007)........................... 161

Figura 6 Substituição de emissões de $\mathrm{CO}_{2}$ entre um projeto $\mathrm{MDL}$ e o nível do reservatório equivalente. 


\section{LISTA DE GRÁFICOS}

Gráfico 1 Aquecimento global da superfície: média multimodelos e intervalos avaliados

Gráfico 2 Comportamento das emissões dos GEE dos países do Anexo 1, excluindo LULUCEF

Gráfico 3 Projeção das emissões mundiais de $\mathrm{CO}_{2}$ no Cenário de Referência

Gráfico 4 Projeção das emissões mundiais de $\mathrm{CO}_{2}$ no Cenário Alternativo

Gráfico 5 llustração do conceito de adicionalidade.

Gráfico 6 Comportamento da curva de aversão ao risco 2007/2008.....

Gráfico 7 Emissões antropogênicas mundiais dos GEE: Cenários RECE e Pós-RECE.

Gráfico 8a Potencial estimado: Abordagem bottom-up 65

Gráfico 8b Potencial estimado: Abordagem top-down. 65

Gráfico 9 Estimativa da distribuição de CER dos projetos registrados por país

Gráfico 10 CER distribuídas por País. 99

Gráfico 11 Equilíbrio no mercado de energia elétrica............................. 120

Gráfico 12 Distribuição da ENA simulada e observada no SE.................. 122

Gráfico 13 ENA projetada para o Sudeste............................................. 126

Gráfico 14 ENA projetada para o Sul.................................................... 126

Gráfico 15 ENA projetada para o Nordeste.......................................... 126

Gráfico 16 ENA projetada para o Norte........................................... 127

Gráfico 17 Nível do reservatório observado e simulado por região............ 134

Gráfico 18 Preço de curto prazo (spot) observado e simulado da energia elétrica $(\mathrm{R} \$ / \mathrm{MWh})$ 
Gráfico 19 Geração térmica convencional observada e simulada por região (MWmed)

Gráfico 20 Consumo de eletricidade com perdas e eficiência energética (GWh)

Gráfico 21 Comportamento do fator de substituição por aumento de capacidade com energia limpa....

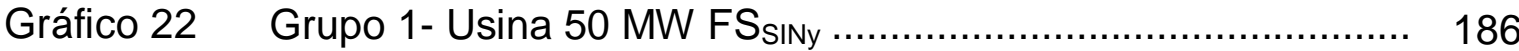

Gráfico 23 Grupo 1 - Usina 500 MW FS

Gráfico 24 Grupo 1 - Usina1000 MW FS

Gráfico 25 Grupo 2 - Usina 50 MW FS

Gráfico 26 Grupo 2 - Usina 500 MW FS

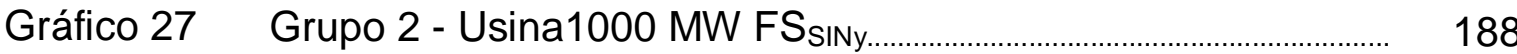

Gráfico 28 Grupo 3 - Usina 50 MW FS

Gráfico 29 Grupo 3 - Usina 500 MW FS

Gráfico 30 Grupo 3 - Usina1000 MW FS 


\section{LISTA DE TABELAS}

Tabela 1 Resultados dos leilões A3 e A5 de energia nova - em MW médios.

Tabela 2 Geração Térmica Convencional 2002-2008 em MW médios

Tabela 3 Geração térmica estimada MW médio mensal.

Tabela 4 Custos macroeconômicos globais estimados para 2030.

Tabela 5 Custos macroeconômicos globais estimados em 2050 para trajetórias de menor custo.

Tabela 6 Distribuição dos projetos registrados no MDL por escopo, reduções CER emitidas e estimativas das CER para 2012........

Tabela 7 Mercado de carbono: volumes e valores em 2005 e 2006

Tabela 8 Estimativa da demanda das unidades de Kyoto em 2010 (MtCO2-eq)

Tabela 9 Estimativa da oferta das unidades de Kyoto em 2010 ( $\mathrm{MtCO}_{2}$-eq/ano)

Tabela 10 Estimativa de preços das unidades de Kyoto em 2010 e 2030

Tabela 11 Distribuição das atividades de projeto no Brasil por tipo de projeto

Tabela 12 Resultados comparados da validação

Tabela 13 Parâmetros utilizados na metodologia

Tabela 14 Fator de emissão dos combustíveis fósseis para geração de eletricidade

Tabela 15 Capacidade Instalada no SIN em 31/12/2007(MW).................. 162

Tabela 16 Empreendimentos em construção........................................... 163

Tabela 17 Carga média de energia SIN - MW médios.............................. 168

Tabela 18 Energia inicial acumulada em MW médio - dez/2007................ 169 
Tabela 19 Geração de térmicas flexíveis no SIN por ano e para todo o período - (TWh) ................................................................ 170

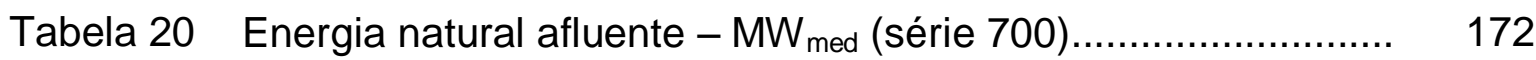

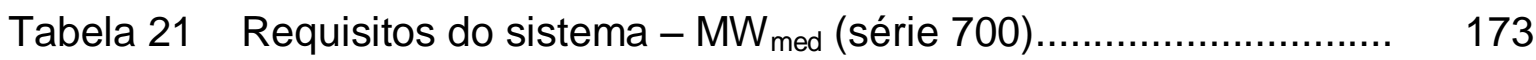

Tabela 22 Custos marginais de operação - $\mathrm{R} \$$ /MWh............................. 173

Tabela 23 Usinas do Sudeste despachadas em 2009, por capacidade, em MW médios (série 700)...

Tabela 24 Emissões por usina conforme o despacho estimado - milhares de $\mathrm{tCO}_{2}$ (série 700)

Tabela $25 \quad \mathrm{CO}_{2}$ evitado por usina de $100 \mathrm{MW}$ médios - milhares de t $\mathrm{CO}_{2}$ (série 700).

Tabela 26 Fator de emissão (tCO $2 / \mathrm{MWh})$ por tipo de combustível............. 177

Tabela 27 Emissões totais no SIN por ano e para todo o período............. 178

Tabela 28 Fatores de emissão no SIN por ano e para todo o período........ 178

Tabela 29 Fator de substituição no período (FS $\mathrm{FSINp})-\mathrm{t} \mathrm{CO}_{2} / \mathrm{MWh}$ Grupo 1

Tabela 30 Fator de substituição anual $\left(\mathrm{FS}_{\mathrm{SINy}}\right) \mathrm{t} \mathrm{CO}_{2} / \mathrm{MWh}$ - mediana Grupo 1

Tabela 31 Fator de substituição período $\left(\mathrm{FS}_{\mathrm{SINp}}\right)-\mathrm{t} \mathrm{CO}_{2} / \mathrm{MWh}$ Grupo 2

Tabela 32 Fator de substituição anual $\left(\mathrm{FS}_{\mathrm{SINy}}\right)$ t $\mathrm{CO}_{2} / \mathrm{MWh}$ - mediana Grupo 2

Tabela 33 Fator de substituição período (FS $\mathrm{SINp})-\mathrm{t} \mathrm{CO}_{2} / \mathrm{MWh}$ Grupo 3

Tabela 34 Fator de substituição anual $\left(\mathrm{FS}_{\mathrm{SINy}}\right) \mathrm{t} \mathrm{CO}_{2} / \mathrm{MWh}$ - mediana Grupo 3

Tabela 35 1a Etapa do exemplo do cálculo do fator emissão calculado pela CIMGC.

Tabela 36 2a Etapa do exemplo do cálculo do fator emissão calculado pela CIMGC.

Tabela 37 3a Etapa do exemplo do cálculo do fator emissão calculado pela CIMGC. 
Tabela $38 \quad 4^{\text {a }}$ Etapa do exemplo do cálculo do fator emissão calculado pela CIMGC.

Tabela 39 Exemplo do cálculo do fator de emissão da margem de construção calculado pela CIMGC

Tabela 40 Fatores de emissão médios anuais do SIN calculados pela CIMGC. 


\section{LISTA DE ABREVIATURAS E SIGLAS}
AAU
Assigned Amount Units
AIE
Agência Internacional de Energia
AJI
Activities Implemented Jointly
AND
Autoridade Nacional Designada
ANEEL Agência Nacional de Energia Elétrica
ARQP Auto-Regressivos Quantílicos de Ordem $p$
BIG Banco de Informação da Geração
BNDES Banco Nacional de Desenvolvimento Econômico e Social
CAR Curva de Aversão ao Risco
CCEE Câmara de Comercialização de Energia Elétrica
CCX Chicago Climate Exchange
CDM Clean Development Mechanism
CE Comitê Executivo
CER Certified Emission Reductions
CGEE Centro de Gestão e Estudos Estratégicos
$\mathrm{CH}_{4} \quad$ Metano
$\mathrm{CO}_{2} \quad$ Dióxido de Carbono
CEPEL Centro de Pesquisa de Energia Elétrica
CIMGC Comissão Interministerial de Mudança Global do Clima
CMSE Comitê de Monitoramento do Setor Elétrico
CNPE Conselho Nacional de Política Energética
COP Conferência das Partes
CQNUMC Convenção - Quadro das Nações Unidas sobre Mudança do Clima
CVU Custo Variável Unitário
EB Executive Board
EIT Economias em Transição
ENA Energias Naturais Afluentes
EOD Entidade Operacional Designada
EPE Empresa de Pesquisa Energética
ERU Emission Reduction Unit
ET Emissions Trade 


\begin{tabular}{ll} 
EU ETS & European Union's Emissions Trading Scheme \\
EUA & Estados Unidos \\
FS & Fator de Substituição \\
FSD & Fator de Substituição Descontado \\
FBMC & Fórum Brasileiro de Mudança Climática \\
GEE & Gases de Efeito Estufa \\
GN & Gás Natural \\
GtCO & Giga tonelada de dióxido de carbono \\
HFCs & Hidrofluorcarbonos \\
IBGE & Instituto Brasileiro de Geografia e Estatística \\
IE & Instituto de Economia \\
IEA & International Energy Agency \\
IETA & State and Trends of the Carbon Market \\
IGES & International Review for Environmental Strategies \\
IP & Incorporação de Perdas \\
IPCC & Painel Intergovernamental sobre Mudança do Clima \\
IPEA & Instituto de Pesquisa Econômica Aplicada \\
JI & Joint Implementation \\
LB & Linha de Base \\
LULUCF & Uso do Solo e Mudança do Uso do Solo e Florestas \\
MCT & Ministério de Ciência e Tecnologia \\
MDL & Mecanismo de Desenvolvimento Limpo \\
ME & Mercado de Emissões \\
MEI & Modelo de Equilíbrio Integrado \\
MMA & Ministério do Meio Ambiente \\
MME & Ministério das Minas e Energia \\
MRE & Ministério das Relações Exteriores \\
NE & Nordeste \\
N & Norte \\
$\mathrm{N}_{2} \mathrm{O}$ & Óxido nitroso \\
NSW & New South Wales Market \\
OCDE & Organização para a Cooperação e Desenvolvimento Econômico \\
OFEE & Oferta Flexível de Energia Elétrica \\
\hline ing &
\end{tabular}




\begin{tabular}{|c|c|}
\hline ONS & Operador Nacional do Sistema \\
\hline $\mathrm{PCH}$ & Pequena Central Hidrelétrica \\
\hline PCT & Pequena Central Termelétrica \\
\hline PDD & Project Design Document \\
\hline PDEE & Plano Decenal de Energia Elétrica \\
\hline PEN & Plano Anual de Operação Energética \\
\hline PFCs & Perfluorcarbonos \\
\hline PIB & Produto Interno Bruto \\
\hline PMO & Programa Mensal de Operação \\
\hline PNMC & Plano Nacional de Mudanças Climáticas \\
\hline PNUD & Programa das Nações Unidas para o Desenvolvimento \\
\hline PoAs & Programas de Atividades \\
\hline ppm & parte por milhão \\
\hline PROINFA & Programa de Incentivo às Fontes Alternativas de Energia \\
\hline RECE & Relatório Especial sobre Cenários de Emissões \\
\hline SAR & Segundo Relatório de Avaliação \\
\hline $\mathrm{SE} / \mathrm{CO}$ & Sudeste - Centro-Oeste \\
\hline SIN & Sistema Interligado Nacional \\
\hline $\mathrm{SF}_{6}$ & Hexafluoreto de enxofre \\
\hline S & Sul \\
\hline $\mathrm{tCO}_{2}$ & Toneladas de dióxido de carbono \\
\hline $\mathrm{tCO}_{2}-\mathrm{eq}$ & Toneladas de dióxido de carbono equivalente \\
\hline TRA & Terceiro Relatório de Avaliação \\
\hline UFRJ & Universidade Federal do Rio de Janeiro \\
\hline UHE & Usina Hidrelétrica \\
\hline UNFCCC & United Nations Framework Convention on Climate Change \\
\hline UTE & Usina Térmica \\
\hline WEO & World Energy Outlook \\
\hline
\end{tabular}




\section{SUMÁRIO}

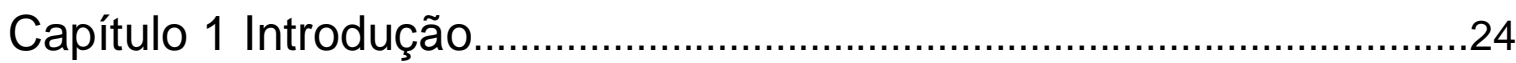

1.1 A constatação das ameaças e o equacionamento político para um Acordo multilateral de longo prazo...............................................24

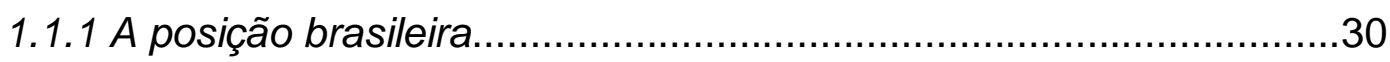

1.1.2 Vulnerabilidades dos países em desenvolvimento e pobres e novas rotas de desenvolvimento......

1.2 Emissões dos GEE, Protocolo de Kyoto e a inserção das economias emergentes por meio do MDL.

1.3 Linha de base de projetos MDL conectados a sistemas elétricos: porque a metodologia aplicada precisa ser repensada.

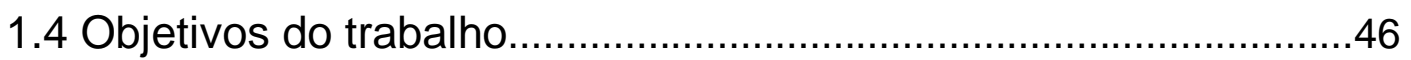

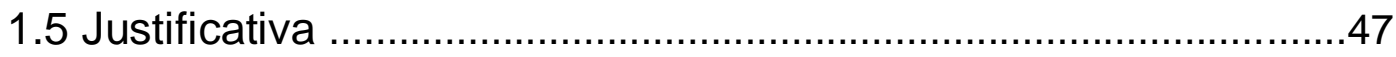

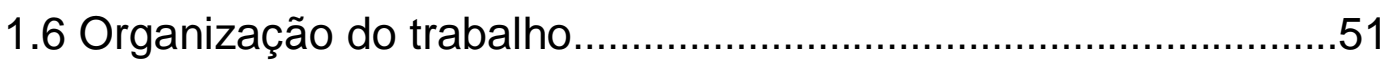

Capítulo 2 Aquecimento global: vulnerabilidades e políticas de mitigação no contexto do pós-2012

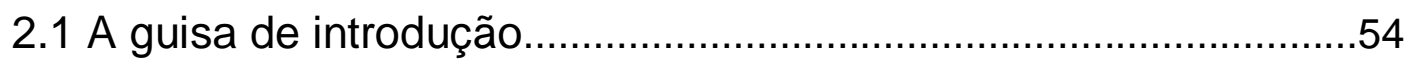

$2.2 \mathrm{O}$ que se sabe sobre os impactos das mudanças

climáticas

2.3 Mitigação e custos da estabilização das concentrações dos GEE na atmosfera

2.4 O efeito mitigador das OPORTUNIDADES sobre os custos da mitigação.

2.50 pós- 2012: Como será? 
Capítulo 3 Protocolo de Kyoto: Mecanismo de Desenvolvimento Limpo e Mercado de Carbono.

3.1 Breve histórico .84

3.2 Mecanismos de Flexibilização: regras e procedimentos .87

3.2.1 O que é e como funciona o MDL?

3.2.2 Conceito e premissas metodológicas da linha de base para sistemas elétricos.

3.3 Protocolo de Kyoto e MDL: Resultados e Mercado de Carbono.

3.4 Balanço do MDL no Brasil. 109

Capítulo 4 Modelo de Equilíbrio Integrado (MEI). .113

4.1 Metodologia do Modelo de Equilíbrio Integrado. 116

4.2 Estrutura e Operacionalidade do MEI .118

4.2.1 Módulo de Previsão dos Requisitos de Carga. 121

4.2.2 Módulo de ENA: Determinação da Oferta Hidrelétrica. 121

4.2.3 Módulo de Vertimento e Perdas. 123

4.3 Modelo Computacional de Equilíbrio Integrado 124

4.4 Validação do MEI 127

4.4.1 Características do modelo NEWAVE versus MEI. 127

4.4.2 Vantagens e Validação do MEI. 130

Capítulo 5 Proposta de metodologia para contabilização de créditos de carbono de projetos de MDL em sistemas elétricos 136

5.1 Considerações Iniciais 136

5.2 Conceito/aplicabilidade. 140 
5.3 Procedimentos para estimar a linha de base de sistema elétrico interligado e calcular o Fator de Substituição do projeto MDL

5.4 Cálculo do Fator de Substituição do período de obtenção de crédito $\left(F S_{\text {SEp }}\right)$ e do Fator de Substituição anual $\left(F_{\text {SEy }}\right)$

5.5 Procedimento de cálculo do fator de emissão dos combustíveis fósseis para a geração de eletricidade.

Capítulo 6 Aplicação da metodologia proposta para estimar o Fator de Substituição para projeto de MDL conectado ao SIN.

6.1 Aspectos Introdutórios

6.2 Aplicação da metodologia para o SIN 158

6.2.1 Identificação do sistema elétrico do projeto. 158

6.2.2 Definição da configuração de base e determinação da energia gerada

6.2.3 Cálculo das Emissões Totais ( $\left.E T_{S I N b}\right)$ e do Fator de Emissão ( $\left.F E_{S I N b}\right)$ : configuração de base.

6.2.4 Cálculo do Fator de Substituição do período ( $\left.F S_{S I N p}\right)$ e anual $\left(F S_{S I N y}\right)$ para os experimentos realizados.

6.3 Apresentação dos Grupos de Experimentos e Resultados.

6.3.1 Descrição dos grupos de experimentos. 182

6.3.2 Resultados Encontrados. 185

6.3.3 Discussão dos Resultados. 190

Capítulo 7 Conclusões, Limitações e Recomendações. 198

7.1 Conclusões 198

7.2 Limitações .204

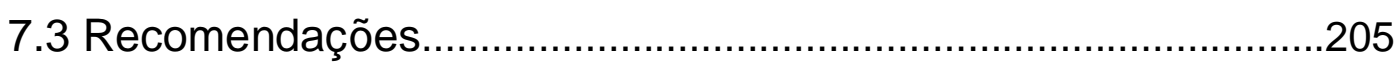

REFERÊNCIAS BIBLIOGRÁFICAS 207 
APÊNDICE A - Descrição da Ferramenta Aprovada pelo CE do MDL para Calcular o Fator de Emissão de Sistema Elétrico

APÊNDICE B - Parque hidrelétrico atual e cenário de expansão das hidrelétricas

APÊNDICE C.1 - Parque termelétrico atual e expansão - Sudeste /

Centro-Oeste 242

APÊNDICE C.2 - Parque termelétrico atual e expansão - Sul. .243

APÊNDICE C.3 - Parque termelétrico atual e expansão -

Nordeste. 244

APÊNDICE C.4 - Parque termelétrico atual e expansão - Norte......245

APÊNDICE D.1: Fator de Emissão ( $\left.\mathrm{tCO}_{2} / \mathrm{MWh}\right)$, Eficiências da Oferta Térmica Convencional do Sudeste. 246

APÊNDICE D.2: Fator de Emissão ( $\mathrm{tCO}_{2} / \mathrm{MWh}$ ) e Eficiências da Oferta Térmica Convencional do Sul

APÊNDICE D.3: Fator de Emissão ( $\left.\mathrm{tCO}_{2} / \mathrm{MWh}\right)$ e Eficiências da Oferta Térmica Convencional do Nordeste.

APÊNDICE D.4: Fator de Emissão ( $\left.\mathrm{tCO}_{2} / \mathrm{MWh}\right)$ e Eficiências da Oferta Térmica Convencional do Norte.

ANEXO A - Quadro SPF 1 250

ANEXO B - Nota de Esclarecimento da CIMGC 251

ANEXO C - Resolução de nํㅛ, de 26 de maio de 200 257 


\section{Capítulo 1 Introdução}

\subsection{A constatação das ameaças e o equacionamento político para um Acordo multilateral de longo prazo}

Ao longo das últimas duas décadas três questões orientaram os inúmeros e polêmicos debates que o tema do aquecimento global provocou entre cientistas, políticos, países, ambientalistas e grupos sociais, de diferentes tamanhos e feitios, de alguma forma interessados no assunto. Em primeiro lugar, a discussão sobre a responsabilidade das atividades humanas para o aquecimento global, segundo, se os efeitos das mudanças climáticas sobre o planeta são iminentes e, finalmente, o que fazer para impedir o agravamento do problema.

Apesar de todas as incertezas e complexidade envolvidas nessas questões, as pesquisas científicas convergiram para o entendimento de que nenhuma causa natural poderia explicar elevações tão repentinas da temperatura média global da Terra.

O Quarto Relatório de Avaliação (AR4, sigla em inglês) do Grupo de Trabalho I (GT I) ${ }^{1}$ do Painel Intergovernamental sobre Mudança do Clima (IPCC, 2007a), que sintetizou a base científica das mudanças climáticas, reduziu significativamente a incerteza quanto à contribuição das ações humanas para elevação da temperatura do planeta, apontando como muito provável², que sejam as atividades humanas relacionadas com a produção de energia e o uso da terra,

\footnotetext{
1. O GT I é responsável pela consolidação no âmbito do Painel Intergovernamental sobre a Mudança do Clima (IPCC, sigla em inglês) de todo conhecimento científico acumulado sobre o clima e sobre as causas naturais e humanas responsáveis pelas mudanças climáticas. Além disso, com base em novos dados e análises faz estimativas sobre a mudança do clima e desenvolve novos modelos que simulam as mudanças e os processos climáticos no futuro. Desse grupo participam diretamente como autores-redatores ou como autores-redatores colaboradores 52 cientistas de todo o mundo.

2 - De acordo com a classificação adotada pelo IPCC é considerado como muito provável aquele evento cuja chance de ocorrer seja maior que $90 \%$
} 
os principais responsáveis pelas elevações das concentrações atmosféricas dos gases de efeito estufa ${ }^{3}$ (GEE) e pelo aquecimento global.

Uma importante novidade do Quarto Relatório de Avaliação relacionada com a segunda questão e que avança em relação aos relatórios anteriores foi identificar que as mudanças climáticas já estão ocorrendo. Exemplos dessas mudanças são as freqüências de ocorrências de temperaturas inesperadas, furacões, tempestades, ciclones tropicais. Ou seja, as mudanças climáticas não são apenas aquelas cujas conseqüências são catastróficas e não reversíveis, que certamente ocorrerão, em prazos mais longos, entre 50 e 100 anos, se as emissões não forem drasticamente reduzidas.

$\mathrm{Na}$ atualidade, os debates se concentram no aperfeiçoamento dos acordos existentes, a exemplo do Protocolo de Kyoto, no estabelecimento de novos acordos globais e no desenvolvimento de programas nacionais por meio dos quais seja possível garantir níveis de concentrações atmosféricas dos gases de efeito estufa, minimamente compatíveis com o equilíbrio energético do sistema climático da Terra.

Os resultados apresentados pelo GT I do IPCC, não deixam dúvidas quanto às ameaças ao sistema climático que representam a continuidade dos padrões de produção e consumo nas próximas décadas, para qualquer cenário de emissões considerado. As projeções dos aquecimentos médios globais da superfície para o final do século XXI (2090-2099) na comparação com aqueles observados entre 1980-1999 foram elaboradas a partir dos cenários de emissões do Relatório Especial sobre Cenários de Emissões (RECE) ${ }^{4}$ do IPCC.

\footnotetext{
3 - Principais gases de efeito estufa: dióxido de carbono $\left(\mathrm{CO}_{2}\right)$, metano $\left(\mathrm{CH}_{4}\right)$, óxido nitroso $\left(\mathrm{N}_{2} \mathrm{O}\right)$, hidrofluorcarbonos (HFCs), perfluorcarbonos (PFCs), hexafluoreto de enxofre $\left(\mathrm{SF}_{6}\right)$

4- As famílias de cenários e casos ilustrativos do RECE são sintetizados no Quadro SFP 1 que se encontra no Anexo $A$ do presente trabalho. Destaque-se que os referidos cenários não consideram iniciativas de mitigação adicionais. Os cenários B1, A1T, B2, A1B, A2 e A1FI estão associados a concentrações atmosféricas de todos os GEE de 600, 700, 800, 850, 1250 e 1550 ppm, respectivamente
} 
De acordo com esses estudos evidenciou-se que

mesmo se todos os agentes do forçamento radiativo se mantivessem constantes nos níveis do ano 2000, uma tendência de aquecimento adicional ocorreria nas próximas duas décadas a uma taxa de cerca de $0,1^{\circ} \mathrm{C}$ por década, em razão principalmente da lenta resposta dos oceanos. Seria esperado cerca do dobro do aquecimento $\left(0,2^{\circ} \mathrm{C}\right.$ por década) se as emissões ficassem na faixa dos cenários do RECE. (IPCC, 2007a, p. 12, tradução nossa).

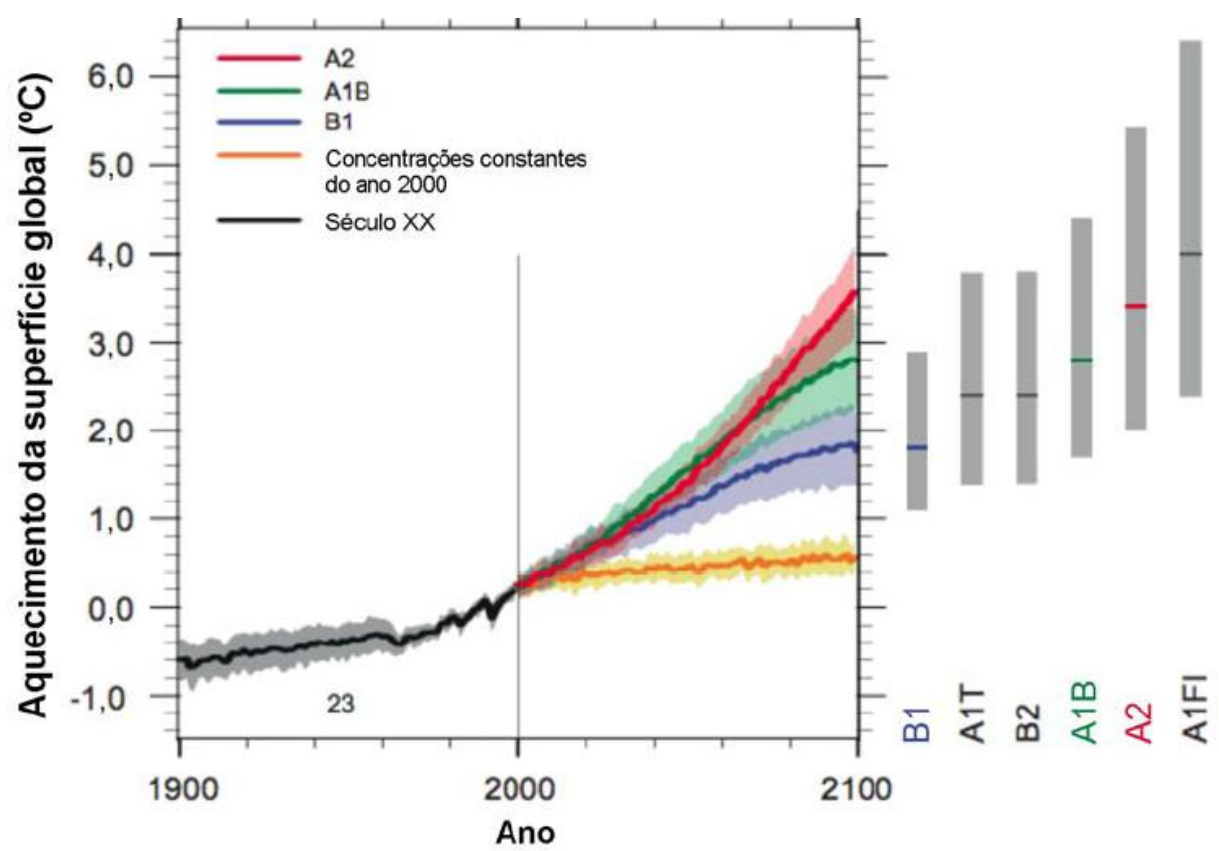

Gráfico 1 - Aquecimento global da superfície: média multimodelos e intervalos avaliados Fonte: IPCC, 2007a, p.20

As linhas contínuas do Gráfico 1 representam as médias globais do aquecimento da superfície produzidas por vários modelos relativas a 1980-1999 para os cenários $A 2$, A1B e B1, mostradas como continuações das simulações do século $\mathrm{XX}$. A linha alaranjada representa o experimento em que as concentrações foram mantidas constantes nos valores do ano 2000. As linhas contínuas dentro de cada coluna cinza à direita indicam a melhor estimativa e a faixa provável avaliada para os seis cenários do RECE.

O Quarto Relatório de Avaliação do IPCC observa ainda que o acoplamento clima-ciclo de carbono acrescentará dióxido de carbono à atmosfera. Porém, como magnitude dessa retroalimentação é incerta, as trajetórias das emissões de 
dióxido de carbono não podem ser traçadas como precisão. No entanto, os modelos sugerem que para estabilizar em 450 ppm de dióxido de carbono, que é o nível considerado aceitável para que a humanidade possa evitar os efeitos mais trágicos do aquecimento global, seria necessário que as emissões cumulativas desse gás, ao longo do século $X X I$, fossem reduzidas de uma média anual de $2.460 \mathrm{GtCO}_{2}$ para $1.800 \mathrm{GtCO}_{2}$ (Ibid., p. 23).

Estima-se que se o fluxo anual de emissões dos GEE continuar a crescer com o mesmo padrão atual, as concentrações atmosféricas ao nível de 550 ppm de $\mathrm{CO}_{2}$-eq será atingido em torno de 2035, o que poderá acarretar numa elevação da temperatura acima de $2^{\circ} \mathrm{C}$ (STERN, 2008). Ou ainda, conforme constata Arroyo (2007), as emissões são crescentes e os impactos decorrentes desse crescimento estão ocorrendo muito antes do que se pensava.

Além disso, devido ao vigoroso crescimento econômico experimentado nos últimos anos, a China e a Índia serão responsáveis por mais da metade do incremento mundial da demanda de energia primária, entre 2006 e 2030 (IEA ${ }^{5}$, 2008). Com efeito, ainda de acordo com a IEA, o conjunto dos países que não pertencem a Organização para a Cooperação e Desenvolvimento Econômico (OCDE) representa $87 \%$ do incremento mundial de energia primária, elevando a participação desses países de $51 \%$ para $62 \%$.

Por essa razão, além dos países desenvolvidos, listados no Anexo $1^{6}$ da Convenção-Quadro das Nações Unidas sobre Mudança do Clima (CQNUMC, 1992), países como a China, Índia, México, África do Sul, alguns países do Oriente Médio e o Brasil, que atualmente não têm obrigações de reduzir suas emissões dos gases de efeito estufa, teriam que aceitar limite de emissões, com possíveis repercussões sobre as atuais estratégias de crescimento econômico dessas nações.

\footnotetext{
5 - Dados publicados no World Energy Outlook (WEO)

${ }^{6}$ - Países do Anexo 1 são as nações industrializados que pertencem a OCDE e os países do leste europeu e da antiga República Soviética designados, genericamente, como Economias em Transição (EIT)
} 
Portanto, o foco das discussões pós-Kyoto e o desafio a ser enfrentado é, simultaneamente, limitar o volume das emissões mundiais, novas rotas tecnológicas de baixas emissões serem desenvolvidas para sustentar 0 crescimento dos países em desenvolvimento e reduzir, significativamente, as atuais emissões dos países desenvolvidos, com o estabelecimento de metas de reduções bem mais ambiciosas do que aquelas fixadas no Protocolo de Kyoto para o primeiro período de compromisso, entre 2008-2012.

Um grande obstáculo que envolve um acordo multilateral como o Protocolo de Kyoto, é que muitos países em desenvolvimento se recusam a trabalhar com metas quantificadas de emissões, sinalizando para uma alternativa de implementação de programas voluntários de reduções das suas emissões, na expectativa de que as nações industrializadas assumam as suas responsabilidades e cumpram com as suas obrigações, conforme estabelece a Convenção sobre a Mudança do Clima.

Outra enorme dificuldade a ser enfrentada, que é, certamente, mais importante para que o pós-2012 não seja um fracasso, é a posição que os Estados Unidos (EUA) assumirão na próxima Conferência das Partes (COP15), a ser realizada em fins de 2009, em Copenhague.

Embora não se aposte numa adesão dos EUA ao Protocolo de Kyoto que implique no compromisso com metas quantificadas, no âmbito de um acordo multilateral, a expectativa é que as respostas e a inserção daquele país no esforço global para redução das emissões dos GEE representem uma clara mudança, que sinalize de forma inequívoca para o mundo o compromisso e o esforço dos EUA para reverter uma tendência de elevação das emissões ao longo do século XXI.

A Conferência das Partes realizada em Bali na Indonésia (COP13) iniciou esse processo de negociação para um Acordo que substitua e/ou aprofunde o Protocolo de Kyoto após 2012. O problema é como viabilizar um acordo a altura 
desse desafio. Para muitos analistas e participantes da COP $14^{7}$, os resultados dessa última conferência foram pífios, ainda que, de acordo com o UNFCCC ${ }^{8}$, a expectativa seja de que uma ação cooperativa, ambiciosa e de longo prazo sobre a mudança climática seja negociada em Copenhagen, em fins de 2009.

Nesse sentido destacam-se, segundo algumas avaliações, os avanços registrados em Poznan (Polônia) com o acordo sobre o estabelecimento do Fundo de Adaptação, com o objetivo de ajudar os países mais pobres a enfrentarem os efeitos mais perigosos das mudanças climáticas e o acordo inicial sobre um mecanismo com vistas a recompensar os países pela redução de emissões decorrentes do desmatamento (Charlton, 2008) ${ }^{9}$.

Apesar das incertezas em relação ao sucesso das negociações em torno de um acordo que seja realmente eficaz para reduzir drasticamente as emissões dos gases de efeito estufa nas próximas décadas, o fato é que o aquecimento global precisa ser combatido sem tréguas, e deve envolver não apenas os EUA, mas também países como o Brasil, a China e a Índia ${ }^{10}$. As sinalizações da comunidade científica internacional indicam que a humanidade tem poucos anos para evitar mais desastres climáticos, cujos efeitos altamente negativos atingiram milhões de pessoas em todo o planeta.

A 15르 COP será a grande oportunidade para que as nações negociem um novo acordo de longo prazo que seja capaz de combinar a garantia do fornecimento da energia com a necessária aceleração do processo de transição para um sistema energético de baixo padrão de emissões dos GEE.

\footnotetext{
7 - A COP14 foi realizada em Poznan na Polônia, entre os dias 1 e 12 de dezembro de 2008

8 - United Nations Framework Convention on Climate Change

9 - Alan Charlton é embaixador do Reino Unido no Brasil.

10. Esses países serão os maiores responsáveis pelas elevações das emissões dos GEE nas próximas quatro décadas, embora em termos per capita as suas emissões continuarão sendo substancialmente menores do que a dos países desenvolvidos.
} 


\subsubsection{A posição brasileira}

A posição do governo brasileiro sobre como deverá ser o acordo multilateral pós2012 é, no mínimo, dúbia. Em Poznan, na COP14, o Brasil, aparentemente, defendeu duas posições. Por um lado, a diplomacia brasileira, através do Ministério das Relações Exteriores (MRE), se posicionava contra o estabelecimento de metas quantificadas de redução das emissões para países em desenvolvimento. Por outro lado, o Ministério do Meio Ambiente (MMA), lançava o Plano Nacional de Mudança do Clima (MMA, 2008), comprometendose em reduzir o desmatamento até $2010 \mathrm{em} \mathrm{40 \%} \mathrm{em} \mathrm{relação} \mathrm{à} \mathrm{média} \mathrm{do} \mathrm{período}$ entre 1996-2005, e 30\% a mais a cada quadriênio seguinte em relação aos quadriênios anteriores ${ }^{11}$. Se essa meta for cumprida haverá, segundo o plano, uma redução das emissões da ordem de $4,8 \mathrm{GtCO}_{2}$ no período entre 2006 $2017^{12}$.

Além dessa meta específica de redução do desmatamento, o plano declara a intenção de agir em outras seis áreas, visando reduzir as emissões, fixando para cada uma dessas áreas as ações e metas a serem cumpridas, sem, contudo, definir como e quais os recursos que contará para implementá-las.

Portanto, a menos que ao longo desse ano e até a realização da COP15 em Copenhagen, o governo brasileiro anuncie sua posição quanto ao nível de compromisso que espera seja possível, em termos da participação dos países em desenvolvimento, no âmbito de um Acordo multilateral e de longo prazo, o que até agora se produziu de concreto foi uma extensa lista de intenções, cujo necessário detalhamento e revisões ainda estão por serem feitos.

Além disso, o PNMC, embora não condicione a implementação das metas/ações para reduzir as emissões dos GEE à ajuda e cooperação internacional, ao declarar que o objetivo do PNMC é "incentivar o desenvolvimento das ações do

\footnotetext{
11 - Vale destacar que essa meta está sendo revista, nos seguintes termos: o período passa a ser qüinqüenal com redução de 40 \% para todos os qüinqüênios até 2020 e não até 2017.

12 - O PNMC, 2008 considerou 100 tC/ha para calcular as emissões evitadas com a redução do crescimento das áreas desmatadas.
} 
Brasil colaborativas ao esforço mundial de combate ao problema e criar as condições internas para o enfrentamento de suas conseqüências" (MMA, 2008, p. 5) deixa claro, de antemão, que a implementação das ações estabelecidas ao longo do plano podem não ser implementadas na sua totalidade.

Esse posicionamento aparece de forma mais clara quando, ao responder a uma questão formulada sobre o que o Brasil pretende para o futuro próximo, referindose aos compromissos em relação às ações para evitar a emissão dos GEE, opta por remeter essa questão para a sociedade, apontando que "as escolhas são feitas à medida que a sociedade reconhece o problema, compreende a dinâmica das múltiplas forças que o provocam, define-se como parte da solução e se vê como beneficiária das decisões tomadas" (Ibid., p. 7).

Ou seja, mesmo reconhecendo que a mudança climática é estratégica para o desenvolvimento futuro do país, observa que o modo como o Brasil irá contribuir para reduzir as emissões mundiais dos GEE levará em conta aspectos de curto prazo da economia brasileira, para avaliar os impactos das ações de mitigação sobre a competitividade da economia e dos produtos brasileiros no âmbito do comércio internacional (MMA, 2008).

Como não define como a "sociedade" se manifestará, nem são estabelecidos os prazos para que isso ocorra, o mais provável é que o Brasil chegue a COP15 com um posicionamento contrário ao estabelecimento de metas quantificadas de redução das emissões para os países em desenvolvimento, negociando a adoção de um programa voluntário, em nível nacional, de redução das emissões, nos moldes atualmente propostos no PNMC.

Especificamente em relação ao setor elétrico, o PNMC é omisso, sobretudo considerando, o forte crescimento das fontes fósseis na matriz elétrica nacional. Limita-se a incorporar ao plano propostas há muito anunciadas no planejamento decenal de expansão do setor elétrico, a exemplo da entrada, até 2010, de 7000 MW de fontes limpas, não emissoras, dois programas envolvendo eficiência energética e co-geração com bagaço de cana, com objetivos fixados para 2030, meta de redução de $10 \%$ anuais das perdas não-técnicas na distribuição de 
energia elétrica e da agregação ao sistema de $34.460 \mathrm{MW}$, provenientes de novas hidrelétricas, de acordo com a programação de obras do Plano Decenal de Energia Elétrica - PDEE, 2007-2016 (MME, 2007).

Ademais, ao mencionar os estudos realizados que apontam para importantes vulnerabilidades às mudanças climáticas da Bacia Amazônica e da Bacia do Paraná, não internaliza essas preocupações ao discurso do plano, nem propõe ações de diversificação da matriz do setor elétrico.

A vulnerabilidade da Bacia Amazônica em relação à geração de energia elétrica é particularmente relevante pelo fato de que mais de $50 \%$ do potencial hidrelétrico não explorado pertencem a ela. Como a expectativa, considerando os cenários projetados em escala regional, é de que haja redução de precipitações, impactando o ciclo hidrológico dessa bacia, espera-se também uma redução da capacidade de geração de energia elétrica a partir dos recursos hídricos ali localizados, durante o século XXI (FREITAS; SOITO, 2008).

Destaque-se que se essa redução de fato ocorrer, mesmo na presença de uma elevação das precipitações na Bacia do Paraná, como projetam os modelos, as repercussões negativas se espalharão sobre todo o Sistema Interligado Nacional $(\mathrm{SIN})$, e, muito provavelmente, com impactos diretos sobre a quantidade de energia firme ofertada pelo sistema (Ibid.).

Em recente artigo publicado na Revista FBMC, Sampa e Nobre mostraram que os resultados encontrados por Ambrizzi et al. $(2007)^{13}$, utilizando três modelos que foram integrados para a América do Sul, a partir de dados obtidos do modelo climático global do Centro de Pesquisa Britânico Hadley Centre para o período entre 2071-2100 na comparação com o período entre 1961-1990, indicam "o maior aquecimento ocorrerá na Amazônia, com aquecimento de 4-8\% para o

\footnotetext{
13 - Ambrizzi. T.; Rocha, R.,; Marengo, J.; Pisnitchenko, A.I.; Alves, L.; Fernandez, J.P.. 2007: Cenários regionalizados de clima no Brasil para o século XXI: projeções de clima usando três modelos regionais. Relatório 3, Ministério do meio Ambiente, Secretaria de Biodiversidade e Florestas, Brasília, fev. 2007
} 
cenário A2 de emissões dos gases de efeito estufa e de 3-5\% para o cenário B2" ${ }^{14}$ (AMBRIZZI et al., 2007 apud SAMPA e NOBRE, 2008).

Esses modelos estimaram também reduções das precipitações no norte e em parte do leste da Amazônia, no cenário B2 e no norte, leste e parte central da Amazônia, no cenário A2. Nesse sentido, os autores destacam os cenários de mudança climática do $\mathrm{HadCM}^{15}$ para o Quarto Relatório de Avaliação do IPCC, prevendo que a duração da estação da seca poderia aumentar em dois meses ou mais na maior parte da Amazônia, com repercussões sobre a climatologia da chuva e a elevação do risco de ocorrência de queimadas.

É evidente que problemas envolvendo custos, continuidade do fornecimento, modicidade tarifária, barreiras tecnológicas, barreiras culturais e gastos adicionais com incentivos financeiros e/ou tributários relacionados com as opções de gerações de energia elétrica a partir de fontes renováveis e não emissoras dos GEE, não são pequenos e nem de simples resolução. Isso dificulta as ações voltadas para a intensificação do uso dessas fontes, sobretudo, quando comparadas com escolhas menos exigentes, como o uso de tecnologias convencionais de geração dominadas e tradicionais, a exemplo da geração hidrelétrica e da geração de eletricidade a partir de fontes fósseis.

No entanto, o problema do aquecimento global e a necessidade de que um Acordo multilateral de longo prazo seja viabilizado e promova reduções significativas das emissões dos GEE, em nível global, não prescinde da participação dos países em desenvolvimento e, em particular, da China, da Índia e do Brasil que serão os maiores responsáveis pela elevação das emissões dos GEE ao longo do século XXI.

Nesse sentido, o Brasil poderá dar uma importante contribuição, mobilizando proativamente recursos naturais e de mercado para ampliar a sua matriz energética renovável, recuperar com reflorestamento áreas degradadas, criar e

\footnotetext{
14 - Conforme descritos no Quadro SFP 1 reproduzido no Anexo A do presente trabalho.

15 - Abreviatura para o Hadley Centre Coupled Model, versão 3, que é acoplado ao Modelo de Circulação Geral Atmosfera- Oceano (AOGCM, na sigla em inglês) desenvolvido pelo Hadley Centre do Reino Unido.
} 
estimular um amplo mercado sustentável de produtos florestais, incentivar a produção agrícola social e ambientalmente sustentável e apoiar a implementação de mecanismos de compensação da "floresta em pé" (MOUTINHO; MARTINS, 2008, p. 22) ${ }^{16}$.

1.1.2 Vulnerabilidades dos países em desenvolvimento e pobres e novas rotas de desenvolvimento

Destaca-se, inicialmente, que embora compreensível que alguns países emergentes se contraponham à adoção de metas quantificadas de emissões, esse posicionamento, se inflexível, reverte-se contra os próprios países em desenvolvimento e/ou pobres, que são os maiores prejudicados com as mudanças climáticas em curso.

Sobre essa questão é muito importante o argumento de Goldemberg (2008), colocando a necessidade de que os países em desenvolvimento revejam profundamente as suas estratégias de crescimento baseadas "em trajetórias de desenvolvimento poluentes e predatórias", e apontando como solução a adoção de "uma trajetória que incorpore ao processo de desenvolvimento as tecnologias mais modernas e menos poluentes que não existiam no passado, mas que existem hoje" (GOLDEMBERG, 2008) ${ }^{17}$.

É notório que os desastres climáticos atingem fortemente não apenas os países pobres, mas também parcelas importantes das populações dos países em desenvolvimento. Com efeito, segundo o Relatório de Desenvolvimento Humano, 2007/2008 do PNUD, entre 2000 e 2004, 250 milhões de habitantes de países emergentes e pobres foram afetados em conseqüência de desastres climáticos hidrometereológicos, contra 5 milhões dos países desenvolvidos.

\footnotetext{
16 - Revista FBMC, № 0, Ano 1, dezembro 2008.

17 - Artigo publicado no jornal O Estado de São Paulo, em 24/05/2008.
} 
Ou seja, independentemente das escolhas políticas que façam os países emergentes em relação ao esforço mundial para reduzir drasticamente o fluxo das emissões dos GEE, o fato é que são eles e os países pobres os mais prejudicados com a permanência das atuais rotas de desenvolvimento baseadas em tecnologias altamente emissoras.

Para qualquer risco de desastre climático a desigualdade também é gritante: enquanto nos países desenvolvidos a proporção é de aproximadamente 60 pessoas para cada 100.000 habitantes, entre 2000-2004, nos países em desenvolvimento, esse número é superior a 5.000 para cada 100.000 pessoas (lbid.).

Note-se, ademais, que ao longo do tempo, eleva-se, consideravelmente, essa desigualdade. Com efeito, 1980-1984 essa proporção era de 2.450 para cada 100.000 e de 50 para cada 100.000 , respectivamente (lbid.).

\subsection{Protocolo de Kyoto e a inserção das economias emergentes por meio do MDL}

O crescimento das emissões dos países desenvolvidos listados no Anexo 1, sem considerar os países com economias em transição (EITs) ${ }^{18}$, corrobora a necessidade de que novos e mais eficazes esforços sejam implementados. Como se pode observar no Gráfico 1, esse crescimento só não foi muito mais elevado devido as reduções das emissões verificadas nos países EITs, que caíram, entre 1990 e 2006, de forma bastante significativa. Sem considerar os EITs, as emissões dos países do Anexo 1 cresceram ao longo de todo o período,

18 - Países EITs: Bulgária, Croácia, Rep. Tcheca, Estônia, Latvia, Hungria, Polônia, Romênia, Rússia, Eslovênia, Eslováquia, Ucrânia. Como esses países tiveram seus PIBs (produto interno bruto) significativamente reduzidos em razão das transformações econômicas que experimentaram nas últimas décadas, as reduções das emissões dos GEE verificadas não podem ser atribuídas a um esforço deliberado e consistente para reduzi-las, mas sim com resultado natural das substanciais quedas observadas nas atividades econômicas desses países, cujas matrizes energéticas eram predominantemente estruturadas à base de carvão mineral. 
atingindo elevações de 10,9\% e 9,9\%, respectivamente, em 2005 e 2006 em relação a 1990.

Com efeito, exceto entre 1990 e 1991, em todos os demais anos observaram-se elevações na taxa de crescimento das emissões, com destaque para o período entre 1995 e 2006, no qual a taxa de crescimento quase triplicou, passando dos $3,3 \%$ registrados entre 1995/1990 para 9,9\% entre 2006/2004.

Além disso, verifica-se que, após atingir uma queda de $41,3 \%$ no volume de emissões, entre 2000/1990, os países EITs do Anexo 1, desaceleram esse movimento de queda, reduzindo esse ritmo em 4,3\%, entre 2006 e 2000.

O comportamento combinado dos países do Anexo 1, incluindo os EITs, reflete exatamente esses movimentos. Assim, depois de atingir reduções nas taxas de crescimento das emissões em 6,9\%, entre 2000/1990, não sustenta esse desempenho e volta a exibir maiores emissões a partir de 2001.

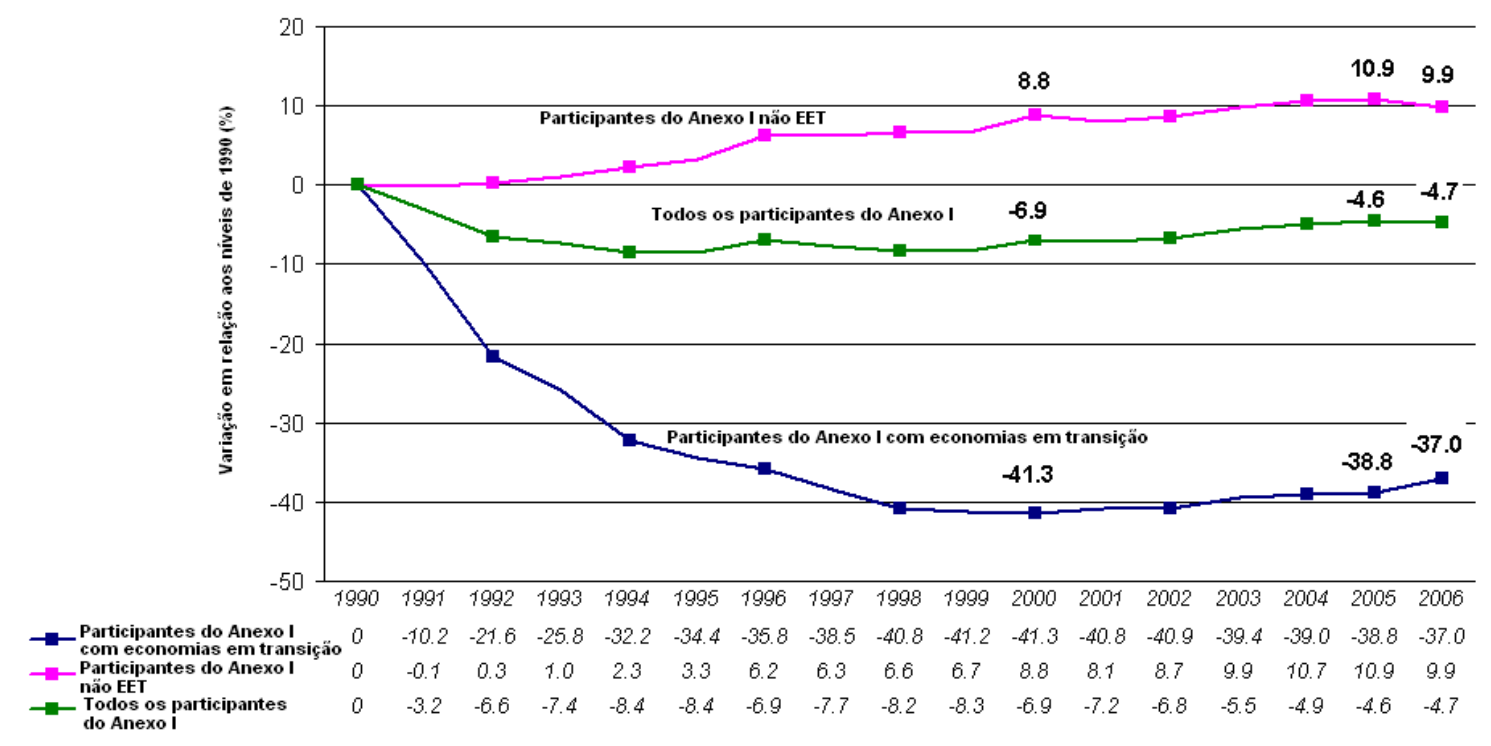

Gráfico 2 - Comportamento das Emissões dos GEE dos países do Anexo 1, excluindo LULUCEF ${ }^{19}$ (tradução nossa)

Fonte: UNFCCC, 2009. Disponível em

http://unfccc.int/files/inc/graphics/image/gif/trends_including_2008.gif (tradução nossa)

19 - Uso do Solo e Mudança do Uso do Solo e Florestas. 
Evidenciam-se, portanto, as insuficiências das iniciativas adotadas pelos países desenvolvidos listados no Anexo 1, não incluindo os países EITs, para reduzirem as suas emissões dos gases de efeito estufa. Além disso, o problema é agravado, como já mencionado, pelo crescimento das emissões em países emergentes, como a China, Índia e Brasil, países que atualmente não possuem metas quantificadas para reduzirem suas emissões e que resistem em aceitar fixá-las após 2012, e pelo posicionamento dos Estados Unidos que não ratificou o Protocolo de Kyoto.

As expectativas para as próximas décadas não são menos preocupantes. De acordo com as projeções da Agência Internacional de Energia (AIE ou IEA, sigla em inglês), publicadas no WEO (2007), se os governos em todo o mundo mantiverem suas atuais políticas, as necessidades energéticas em 2030 serão $50 \%$ superiores às atualmente verificadas, com os combustíveis fósseis dominando o padrão do consumo energético mundial e o inevitável aumento das emissões do dióxido de carbono $\left(\mathrm{CO}_{2}\right)$.

Ainda com base nessas análises, no cenário de referência ${ }^{20}$, a demanda mundial por energia primária aumentará significativamente até 2030 , com acréscimo de aproximadamente 6 bilhões de tep, entre 2005 e 2030. As emissões mundiais de $\mathrm{CO}_{2}$, que em 2005 registraram $27 \mathrm{Gt}$, crescerão 57\%, entre 2005 e 2030, atingindo nesse último ano 42 Gt. O Gráfico 3 ilustra esse comportamento ascendente das estimativas das emissões de dióxido de carbono, considerando o cenário de referência.

${ }^{20}$ - Cenário de referência pressupõe a manutenção das atuais políticas governamentais em relação à produção e uso da energia no mundo. 


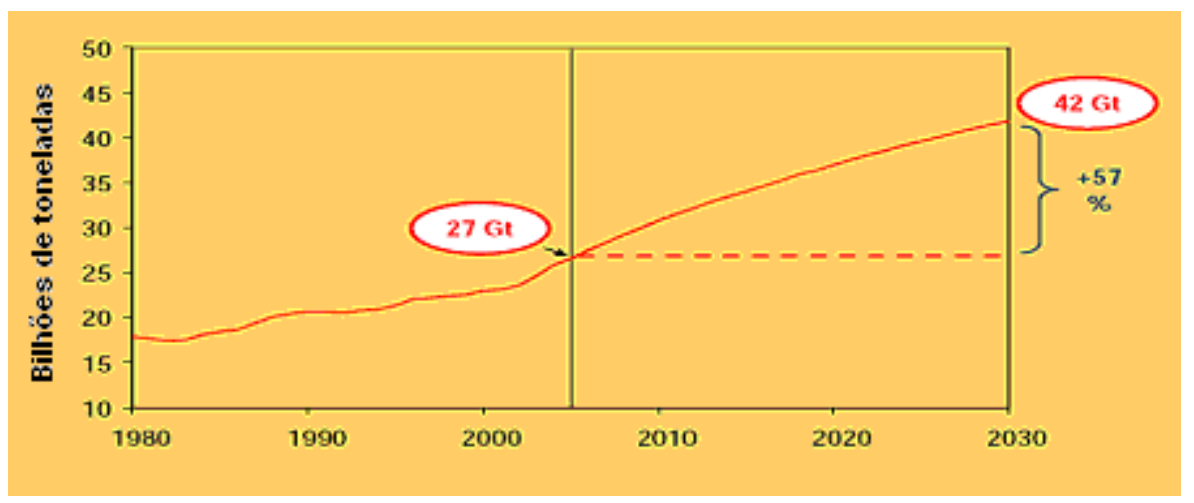

Gráfico 3 - Projeção das Emissões Mundiais de $\mathrm{CO}_{2}$ no Cenário de Referência Fonte: IEA, $2007^{21}$ (tradução nossa)

No cenário alternativo ${ }^{22}$, que prevê crescimento menor das necessidades energéticas mundiais, as emissões mundiais de $\mathrm{CO}_{2}$ seriam inferiores àquelas estimadas para o cenário de referência. $O$ Gráfico 4 mostra que no cenário alternativo as emissões mundiais atingiriam $34 \mathrm{GtCO}_{2}$ em 2030, ou seja, $19 \%$ abaixo das projeções associadas ao cenário de referência.

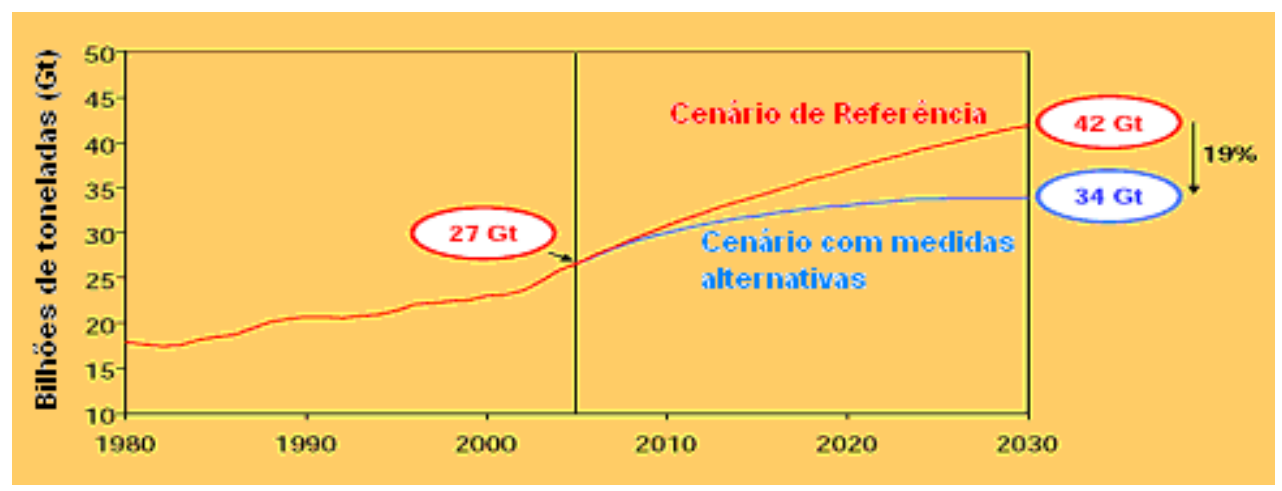

Gráfico 4 - Projeção das Emissões Mundiais de $\mathrm{CO}_{2}$ no Cenário Alternativo Fonte: IEA, $2007^{23}$ (tradução nossa).

Ainda com base nas informações da IEA (2007), na hipótese do cenário alternativo continuar sendo implementado após 2030, as concentrações dos GEE se estabilizariam em 550 partes por milhão $(\mathrm{ppm})$, com aumento médio de $3^{\circ} \mathrm{C}$ em relação aos níveis pré-industriais. Para que a estabilização desses níveis seja

\footnotetext{
${ }^{21}$ - Key Strategic Challenges

22 - No Cenário Alternativo (IEA, 2007) as políticas governamentais seriam redesenhadas com ênfase na substituição das fontes fósseis de energia por fontes alternativas e na implementação de medidas de eficiência e conservação energética.

23 - Key Strategic Challenges
} 
de 450 ppm em 2030, que corresponderia a uma elevação média da temperatura de $2,4^{\circ} \mathrm{C}$, as emissões de $\mathrm{CO}_{2}$ deveriam atingir o teto em 2012 , reduzindo-se consistentemente até 2030 até atingir $23 \mathrm{GtCO}_{2}$ em nível mundial. Não é uma tarefa fácil.

A inserção dos países em desenvolvimento por meio do MDL

Apesar do reconhecimento internacional de que as metas estabelecidas no Protocolo de Kyoto não são suficientes para garantir as reduções de emissões dos GEE nas quantidades necessárias para que o processo de aquecimento do planeta não represente uma séria ameaça para a humanidade, alguns países listados no Anexo 1, cumpriram ou mesmo superaram essas metas, demonstrando que esse é um caminho viável e, portanto, deve ser aprofundado, após 2012.

Nesse sentido, um sumário das avaliações de diversos especialistas em nível mundial, apresentado por Shimada (2004), mostra que todos eles acreditam que o Protocolo de Kyoto é um importante passo e tem transformado de fato o regime da mudança do clima, nacional e internacionalmente. Chama a atenção para o papel que representa, para o cumprimento das metas estabelecidas no Protocolo, o estabelecimento do European Union's Emissions Trading Scheme (EU ETS) o Mecanismo de Desenvolvimento Limpo (MDL), que se firmaram antes mesmo de o Protocolo entrar em vigor.

Parte das metas de reduções das emissões foi alcançada com a ajuda dos mecanismos de flexibilização ${ }^{24}$ previstos no Protocolo de Kyoto (UNFCCC, 1997). Esses mecanismos foram criados para ajudar, em caráter complementar, os países listados no Anexo 1 a cumprirem suas metas quantificadas de reduções

24 - Os mecanismos são: Implementação Conjunta (Joint Implementation - Jl); Comércio de Emissões (Emissions Trade - ET) e o Mecanismo de Desenvolvimento Limpo - MDL (Clean Development Mechanism - CDM). 
das emissões dos GEE. Os dois primeiros mecanismos só podem ser utilizados e executados entre os países do Anexo I.

Os países que não fazem parte do Anexo 1 participam apenas do Mecanismo de Desenvolvimento Limpo (MDL), que tem como objetivo contribuir para a redução das emissões dos gases de efeito estufa em países em desenvolvimento, ou não Anexo 1, a partir dos investimentos em tecnologias limpas, da busca de maior eficiência energética e do uso de fontes alternativas de energia. (Ibid.)

Por meio do MDL, as atividades de projetos que resultem em redução de emissão, valerão créditos, que poderão ser transacionados no mercado internacional de carbono. Os países em desenvolvimento que atualmente não têm obrigações de redução de suas emissões podem hospedar atividades de projetos que reduzam as emissões dos gases de efeito estufa e contribuam para o desenvolvimento sustentável (Ibid.).

Por sua vez, os países desenvolvidos, que têm obrigações de redução das suas emissões, poderão utilizar os Certificados de Emissões Reduzidas (CER) resultantes das atividades de projetos, para cumprir, parcialmente, seus compromissos quantificados de limitação e redução das emissões desde que certificadas por Entidades Operacionais Designadas (EOD) pelo Comitê Executivo (CE) do MDL (Ibid.)

Observe-se que o MDL ao associar as atividades do projeto à contribuição que possam dar para o desenvolvimento sustentável do país hospedeiro, embutiu a necessidade de que sejam definidos critérios de elegibilidade, por meio dos quais poderão ser identificados os projetos elegíveis como MDL.

Além disso, determinou que as reduções das emissões decorrentes das atividades dos projetos sejam adicionais àquelas que ocorreriam na ausência do projeto. Assim, para que um projeto seja elegível como MDL é necessário que se enquadre nos critérios de elegibilidade definidos pelo país hospedeiro e, simultaneamente, deve demonstrar que é capaz de gerar adicionalidade, entendida como o volume de gases de efeito estufa que o projeto é capaz de 
reduzir ou deslocar, tomando-se como referência uma determinada Linha de Base ou Cenário de Referência.

O conceito de adicionalidade é um elemento chave para o desenvolvimento de projetos no âmbito do MDL. De acordo com o parágrafo 43 do Anexo, Modalidades e Procedimentos para um Mecanismo de Desenvolvimento Limpo: "uma atividade de projeto de MDL é adicional se reduzir emissões antrópicas de gases de efeito estufa por fontes para níveis inferiores aos que teriam ocorrido na ausência da atividade de projeto de MDL registrada". (UNFCCC, 2001, p.38) ${ }^{25}$

Ou ainda, conforme definição adotada no Manual de Capacitação Mudança Climática e Projetos de Mecanismo de Desenvolvimento Limpo: um projeto será considerado adicional quando puder comprovar ou demonstrar que não teria sido implementado na ausência dos incentivos relacionados ao MDL, seja eles de cunho econômico ou tecnológico. (CGEE ${ }^{26}, 2008$, p. 60)

O Gráfico 5 ilustra esse conceito.

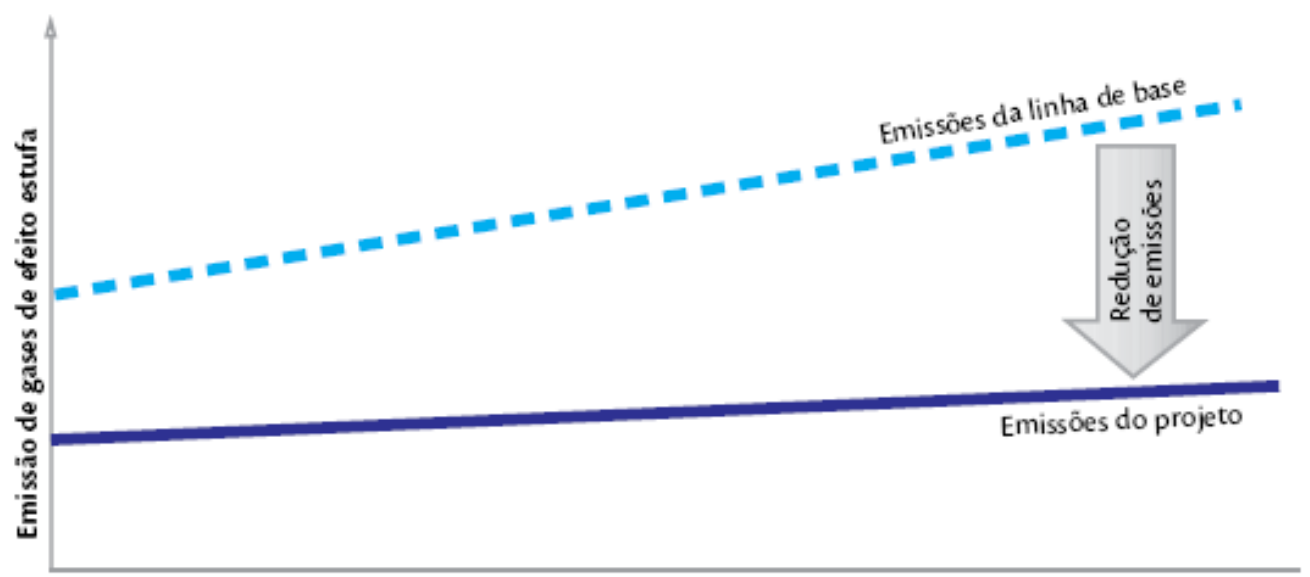

Gráfico 5 - llustração do conceito de adicionalidade Fonte: CGEE, 2008, p. 61

\footnotetext{
25 - Anexo da Decisão 17/CP7.

26- Centro de Gestão e Estudos Estratégicos. Disponível em:

$<$ http://www.cgee.org.br/publicacoes/mar cost php>
} 
Um requerimento básico para os projetos candidatos ao MDL é demonstrar que eles são adicionais, ou seja, suas atividades efetivamente reduzem as emissões dos GEE e os volumes dessas reduções podem ser quantificados, considerando um cenário de referência ou uma linha de base. Assim, nos termos do Anexo 1 sobre modalidades e procedimentos para um desenvolvimento limpo,

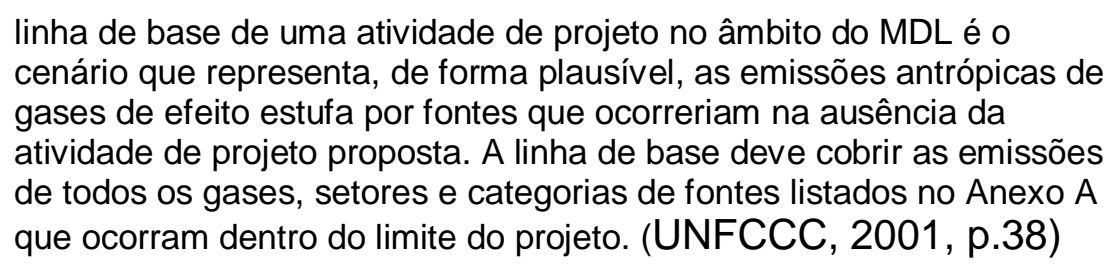

O nível de complexidade para a determinação da linha de base de um projeto candidato ao MDL varia em função de algumas de suas características além de outros aspectos como abrangência, delimitação de fronteiras, confiabilidade dos dados disponíveis e dos cenários projetados, entre outras. Quando se trata de projeto que substituirá um empreendimento apenas planejado, a definição da linha de base não é uma tarefa simples, exigindo cuidados especiais para a sua determinação.

Sistemas elétricos hidrotérmicos interligados, predominantemente hídricos, apresentam maior nível de dificuldade, em função das incertezas associadas ao despacho das usinas térmicas convencionais. Tentando responder e superar essas dificuldades o Comitê Executivo (CE) do MDL aprovou, ao longo dos últimos quatro anos, metodologias com o objetivo de mensurar essas emissões.

Os dados mais recentes publicados pelo UNFCCC, $2009^{27}$ mostram que os mais de 4.200 projetos candidatos ao MDL apresentados, possam gerar até 2012, 2,9 bilhões de CER. Os 1.462 projetos registrados geraram quase 1,5 bilhão de CER, sendo que desse total a China participa com $56 \%$, a Índia com $12 \%$ e o Brasil com $7 \%$.

Atualmente 157 metodologias já foram aprovadas pelo CE do MDL para estimar a linha de base, envolvendo 1.462 projetos registrados e 55 com registro sendo

27 - Disponível em: <http://cdm.unfccc.int/Statistics/index.html>, Acesso em: 18/03/2009 
requerido. As metodologias relacionadas com projetos da indústria de energia (fontes renováveis e não renováveis) perfazem $27 \%$ do total, seguidas das metodologias para projetos de indústrias, com $15 \%$ e das metodologias de florestamento e reflorestamento e de manejo e uso do lixo que representam 10\% e 9\%, respectivamente, do total (UNFCCC, 2009). Ressalte-se que uma metodologia pode estar associada a mais de um escopo.

\subsection{Linha de base de projetos MDL conectados a sistemas elétricos: porque a metodologia aplicada precisa ser repensada}

Com base em oito metodologias, que foram previamente submetidas e aprovadas, o Comitê Executivo do MDL consolidou, em setembro de 2004, a metodologia $\mathrm{ACM}^{28} 0002$, a ser aplicada em projetos de geração de energia elétrica que utilizam fontes renováveis de energia a serem conectados a sistemas elétricos.

Entre setembro de 2004 e setembro de 2007, a ACM 0002 passou por diversas revisões e em outubro de 2007 ela foi parcialmente modificada, no que se refere ao cálculo da linha de base de projeto de geração de eletricidade a ser conectado a sistema elétrico. Por meio dessa alteração, independentemente do tipo e escopo do projeto candidato ao MDL, se as atividades do projeto deslocam eletricidade gerada por centrais do sistema elétrico, então, para determinar a linha de base do projeto, deverá ser usado a Tool to calculate the emission factor for an electrity system ${ }^{29}$, aprovado pelo Comitê Executivo do MDL (UNFCCC/CDM, 2007).

Esta ferramenta metodológica determina o fator de emissão do sistema elétrico ou a linha de base que representa quanto da eletricidade gerada pelas usinas do sistema, medido em $\mathrm{tCO}_{2} / \mathrm{MWh}$, será deslocada com a entrada do projeto supostamente mitigador das emissões de gases de efeito estufa. Portanto, ela

\footnotetext{
${ }^{28}$ - Approved Consolidated Methodology

29 - Aprovado na 35ㄹ reunião do Comitê Executivo do MDL, EB 35 Report, Annex 12, v. 01
} 
determina a linha de base (ou o fator de emissão) das atividades de projetos que substituem eletricidade gerada na rede elétrica.

De acordo com essa ferramenta metodológica, o fator de emissão do sistema elétrico, que mede o deslocamento da energia gerada pelas usinas que servem ao sistema elétrico pela entrada do projeto $\mathrm{MDL}$, é calculado com base nos conceitos da margem operacional, da margem de construção e da margem combinada (lbid.).

A margem operacional é definida pelo conjunto de usinas existentes, cujas gerações podem ser afetadas com as atividades do projeto de MDL. Essa medida é dada pelo fator de emissão da margem operacional, calculado com base nas energias geradas pelas usinas que estão operando na margem do sistema elétrico e nos seus respectivos fatores de emissão que refletem, em última instância, o montante de emissões por unidade de energia que poderá ser deslocado com a entrada do projeto de MDL(lbid.).

A margem de construção se refere aos empreendimentos cujas construções mais recentes poderão ser afetadas com a implementação das atividades do projeto MDL. O fator de emissão da margem de construção é calculado com base num provável deslocamento das emissões por unidade de energia gerada associado às emissões do conjunto de capacidade adicional ao sistema elétrico que compreende $20 \%$ da geração do sistema, recentemente instalada no sistema elétrico (lbid).

A margem combinada reflete o fator de emissão do sistema elétrico, sendo calculada pela média ponderada dos fatores da margem operacional e da margem de construção. Os fatores de ponderação sugeridos na ferramenta são variáveis em função das tecnologias de geração do projeto de MDL e do período de obtenção de créditos. Os proponentes também podem propor alternativas dos pesos para consideração do CE do MDL.

Para calcular o fator da margem operacional são sugeridos quatro métodos. Qualquer um deles poderá ser adotado de acordo com as características 
específicas do projeto e do grau de informações confiáveis disponíveis em nível do sistema elétrico.

No Brasil o método $c$ da Tool to calculate the emission factor for an eletricity system foi adotado pela Comissão Interministerial de Mudança Global do Clima (CIMGC) para calcular a linha de base do Sistema Interligado Nacional (SIN). No entanto, ainda subsistem muitos problemas, sobretudo porque tais métodos não levam em conta os cenários projetados das fontes energéticas, em termos do perfil e participação, que no futuro fornecerão a energia elétrica requerida pelo mercado.

Observe-se que os dois parâmetros, acima mencionados, referem-se às usinas que já estão operando na margem ou foram recentemente construídas. Essa abordagem, embora seja bastante acurada, não sinaliza para o comportamento futuro, em termos dos volumes que serão gerados pelo conjunto das usinas que formam a margem operacional e a margem de construção.

No Apêndice $A$ do presente trabalho encontra-se uma descrição detalhada da aplicação dessa ferramenta metodológica pela CIMGC para calcular o fator de emissão do SIN, entre 2006 e 2008.

\subsection{Objetivos do trabalho}

Essa pesquisa tem como primeiro objetivo discutir e propor um novo referencial metodológico para estimar a linha de base para projetos de MDL a serem conectados a sistema elétrico interligado, a partir de uma visão do mix futuro das fontes energéticas que serão responsáveis pelas gerações de energia, nos próximos dez anos. 
Objetiva também aplicar essa nova abordagem para calcular as emissões deslocadas pelas atividades de projetos de MDL, supostamente mitigador dos GEE, através do cálculo do Fator de Substituição, medido em tCO $/ 2 / \mathrm{MWh}$.

O Fator de Substituição estima a redução das emissões do sistema elétrico decorrente do deslocamento de parte da energia gerada pelas usinas térmicas convencionais, pela entrada no sistema de usinas que geram energia limpa e/ou pela redução da demanda agregada do sistema elétrico pela implementação de programas/medidas de eficiência energética pelo lado da demanda.

Para tanto, usando um modelo que simula o equilíbrio entre a oferta elétrica e os requisitos de energia previstos para o horizonte de 10 anos de energia calcula-se, inicialmente, as emissões dos GEE do sistema elétrico sem considerar a entrada do projeto de MDL. Na seqüência, as emissões do sistema elétrico são novamente calculadas, considerando a entrada do projeto MDL.

O Fator de Substituição é então estimado pela diferença entre as emissões do sistema elétrico sem o projeto e as emissões apuradas após a entrada do projeto MDL dividida pela energia ofertada e/ou reduzida pelas atividades do projeto mitigador dos GEE.

\subsection{Justificativa}

Sustenta-se nessa tese que é pouco provável, pelo menos em relação ao SIN, que as condições observadas em anos recentes ou atuais se reproduzam no futuro. Ao contrário do que ocorria até poucos anos atrás, em que a expansão do sistema elétrico era basicamente assentada em empreendimentos hidrelétricos, na atualidade desenha-se uma clara tendência à fossilização da matriz do setor elétrico nacional. 
A expressão mais contundente dessa tendência se verifica nos resultados dos leilões para o fornecimento de energia nova, onde $60 \%$ da oferta adicional serão realizados por usinas térmicas convencionais (gás natural, carvão, óleo combustível e diesel), contra $38 \%$ da oferta adicional provenientes de fonte hídrica e, apenas $2 \%$ de fonte renovável não convencional (biomassa e eólica), considerando o horizonte de planejamento até 2017.

É importante ressaltar que até 2013, de um total de 14.962 MW médios adicionais, 10.211 MW médios serão gerados pelas usinas térmicas convencionais, representando $68 \%$ da expansão do parque elétrico nacional.

Na Tabela 1 são apresentados os resultados dos leilões acima mencionados.

Tabela 1 - Resultados dos leilões A3 e A5 energia nova em MW médios ${ }^{30}$

\begin{tabular}{rrrrrrrr}
\hline & Hidro & \multicolumn{1}{c}{$\begin{array}{l}\text { Termo } \\
\text { Conv. }\end{array}$} & Biomassa & $\begin{array}{c}\text { Energia } \\
\text { Renovável }\end{array}$ & $\begin{array}{c}\text { Santo } \\
\text { Antônio }\end{array}$ & Jirau & Total \\
\hline 2008 & 71 & 530 & 31 & - & - & - & 632 \\
2009 & 1074 & 1399 & 110 & - & - & - & 2583 \\
2010 & 889 & 2166 & - & 186 & - & - & 3241 \\
2011 & 569 & 1550 & 61 & - & - & - & 2180 \\
2012 & 715 & 1597 & - & - & 52 & - & 2364 \\
2013 & 121 & 2969 & 35 & - & 392 & 445 & 3963 \\
2014 & - & - & - & - & 607 & 386 & 993 \\
2015 & - & - & - & - & 499 & 332 & 832 \\
2016 & - & - & - & - & 58 & 219 & 277 \\
\hline Total & 3439 & 10211 & 237 & 186 & 1609 & 1383 & 17065 \\
\hline
\end{tabular}

Cabe destacar ainda o crescimento da geração térmica convencional observada em 2008, cuja quantidade produzida foi mais de duas vezes superior àquela realizada em 2007. Quando comparada a 2004, ano em que foi registrado o segundo maior volume de geração das térmicas convencionais, a geração em

\footnotetext{
${ }^{30}$ - Tabela elaborada a partir das informações disponibilizadas pela Câmara de Comercialização de Energia Elétrica (CCEE), em outubro de 2008.
} 
2008 foi $23 \%$ superior. A Tabela 2 apresenta a geração das térmicas convencionais entre 2002 e 2008.

Tabela 2 - Geração Térmica Convencional 2002-2008 MW médios ${ }^{31}$

\begin{tabular}{llllllll}
\hline & 2008 & 2007 & 2006 & 2005 & 2004 & 2003 & 2002 \\
\hline SIN & 4158 & 2126 & 2298 & 2325 & 3779 & 1750 & 1991 \\
\hline
\end{tabular}

$\mathrm{Na}$ Tabela 3 encontram-se os resultados das simulações realizadas pelo modelo de equilíbrio utilizado nesse trabalho, que confirmam essa tendência de alta, indicando que os requisitos médios mensais projetados entre 2008-2017 são crescentes, com algumas inversões, porém superiores àquelas registrados entre 2002 e 2007.

Tabela 3 - Geração térmica estimada MW médio mensal

\begin{tabular}{lllllllllll}
\hline & 2008 & 2009 & 2010 & 2011 & 2012 & 2013 & 2014 & 2015 & 2016 & 2017 \\
\hline SIN & 4224 & 3995 & 4338 & 4224 & 4795 & 5023 & 3881 & 4452 & 5365 & 6621 \\
\hline
\end{tabular}

Além disso, observa-se que a política operativa do SIN está se modificando no sentido de elevar a curva de aversão ao risco. Caso essa nova visão prevaleça, necessariamente, haverá aumentos nos despachos das térmicas convencionais, na medida em que mais rapidamente os reservatórios atingirão os novos níveis críticos estabelecidos pela curva de aversão ao risco. Com efeito, vale lembrar a decisão do Comitê de Monitoramento do Setor Elétrico (CMSE), de 18 de junho de 2008, aumentando o nível da Curva de Aversão ao Risco (CAR) para os principais reservatórios, $51 \%$ para o SE/CO e $35 \%$ para o NE.

O Gráfico 6 mostra o ajuste feito na curva de aversão ao risco do subsistema Sudeste - Centro-Oeste (SE/CO), a partir de dezembro de 2007. Se a energia armazenada for inferior aos níveis recomendados pela CAR, então as usinas

\footnotetext{
31. Tabela elaborada a partir de dados publicados pelo ONS (2008a). Disponível em: http://www.ons.org.br/historico/geracao_energia.aspx
} 
térmicas convencionais serão despachadas com base na Resolução CNPE n . 08, de 20/12/2007, de garantia de suprimento energético.

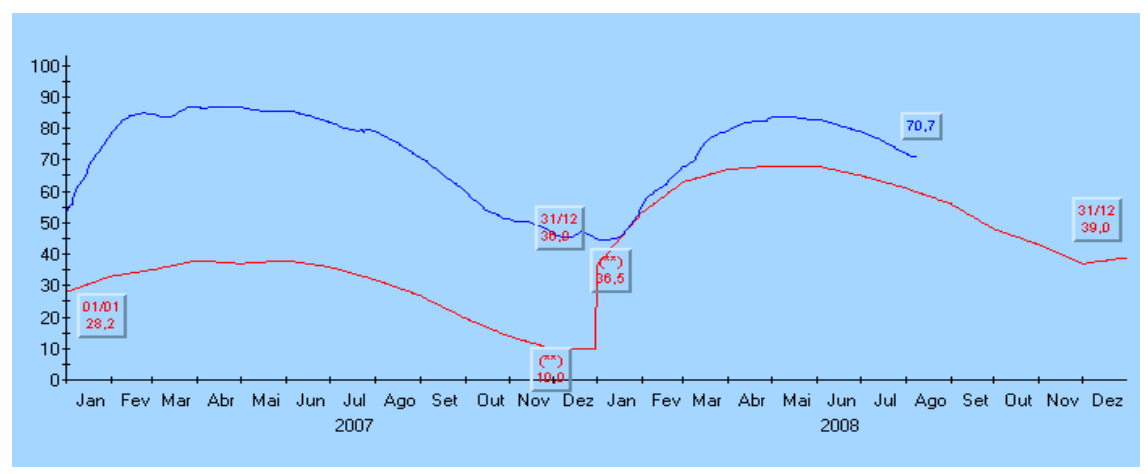

Gráfico 6 - Comportamento da Curva de Aversão ao Risco - 2007/2008

_ Curva de Energia Armazenada Verificada

Curva de Aversão ao Risco

Fonte: ONS, 2008 b. Disponível em

http://www.ons.org.br/avaliacao_condicao/curva_aversao.aspx

Tudo somado reforça a necessidade de que novas e mais amplas abordagens metodológicas sejam desenvolvidas que, levando em conta as incertezas associadas ao despacho hidrotérmico futuro do SIN, sejam capazes de expressar de forma realista e mensurável, os cenários futuros do mix das usinas que comporão a margem operacional do SIN.

A presente proposta metodológica apóia-se ainda nos parágrafos $45(\mathrm{e})$ e 46 das Modalidades e Procedimentos para um Mecanismo de Desenvolvimento Limpo, segundo os quais a linha de base deve ser estabelecida

\footnotetext{
levando em conta as políticas e circunstâncias nacionais e/ou setoriais pertinentes, tais como as iniciativas de reforma setorial, a disponibilidade local de combustíveis, os planos de expansão do setor elétrico e a situação econômica do setor do projeto (UNFCCC, 2001, p.38)
}

O parágrafo 46 estabelece que "a linha de base pode incluir um cenário no qual as futuras emissões antrópicas por fontes são projetadas acima dos níveis atuais, em razão das circunstâncias específicas da Parte anfitriã" (Ibid., p.38). 
Nessas condições, além das informações sobre os fatores de emissões observados, os proponentes dos projetos (entidades públicas e privadas) precisam desenvolver e/ou adotar ferramentas qualitativas e quantitativas de análise e avaliação sobre o comportamento futuro dos fatores de emissões. $O$ desenvolvimento de tais ferramentas e o acesso a elas aos formuladores de política, empresas e consultores que desenvolvem projetos de MDL justifica-se pelas seguintes razões:

1 - O setor elétrico brasileiro, algumas instituições de pesquisa e empresas privadas já dispõem de base de dados e de modelos que simulam o futuro despacho hidrotérmico do SIN, com razoável grau de confiabilidade;

2 - Parte importante do planejamento da expansão da oferta do setor elétrico, no horizonte de cinco anos, baseia-se nos resultados dessas simulações, em particular nos resultados do Newave;

3 - Há documentação oficial de planejamento da expansão, o Plano Decenal de Expansão de Energia Elétrica - PDEE, contendo informações detalhadas sobre as necessidades de geração para atendimento aos requisitos de mercado, para o horizonte de 10 anos de planejamento;

4 - Calcular as emissões dos GEE associadas a esses despachos torna-se um processo simples, seguro e de baixo custo, desde que sejam obtidos os resultados das simulações relativas ao provável despacho hidrotérmico futuro;

5 - Considerando o cenário de continuidade do Protocolo de Kyoto após 2012, que é o mais provável de ocorrer, crescentemente o Brasil precisará ampliar o seu portfolio de projetos que reduzem emissões dos GEE, seja para ampliar a sua participação no mercado de carbono, seja pelo desenvolvimento de programas voluntários, seja para cumprir metas quantificadas de redução das emissões.

O presente trabalho é uma proposição nessa direção. 


\subsection{Organização do trabalho}

O presente trabalho foi estruturado em sete capítulos, quatro apêndices e três anexos, listas de tabelas, gráficos e siglas e referências bibliográficas e consultadas, além desse Capítulo 1 de Introdução, que trata da relevância do tema e da importância do Protocolo de Kyoto e do MDL na atualidade e após 2012, anuncia o objetivo e a justificativa do trabalho e descreve a estruturação do mesmo, em termos de desenvolvimento, conclusões, limitações e recomendações.

No Capítulo 2 são apresentadas as principais conclusões dos Grupos de Trabalho II e III do Quarto Relatório de Avaliação do IPCC, relativamente às vulnerabilidades e medidas de adaptação e mitigação das emissões dos GEE. Fornece ainda, com base nos cenários projetados pelo RECE e pelo Relatório $S_{\text {Stern }}{ }^{32}$, as informações sobre o comportamento mundial das emissões nas próximas décadas, os custos e os co-benefícios associados à adoção de novas políticas e ações para reduzir as taxas de crescimento das emissões dos GEE, nas próximas duas décadas. O Capítulo 2 é finalizado com uma discussão dos principais temas abordados internacionalmente e sobre as expectativas e propostas desenvolvidas para o pós-2012, ano que se encerra o primeiro período do Protocolo de Kyoto, com base nas informações, cenários e análises desenvolvidas pela IEA, 2008.

O Capítulo 3 explora o Mecanismo de Desenvolvimento Limpo (MDL), com ênfase nos procedimentos e condicionantes para a determinação da linha de base e da adicionalidade de projetos candidatos ao MDL. Apresenta as estatísticas das metodologias aprovadas por escopo de projetos, analisa os resultados em nível internacional e fornece uma visão panorâmica sobre o mercado internacional de carbono e o MDL no Brasil, em relação aos projetos aprovados e escopo desses projetos e as linhas gerais do Plano Nacional de

\footnotetext{
32 - O Relatório Stern - Economia das Mudanças Climáticas, publicado em 2007, foi encomendado pelo Governo Britânico como uma contribuição para avaliar as evidências e construir um entendimento sobre a economia das mudanças climáticas no mundo.
} 
Mudanças Climáticas (PNMC) elaborado sob a coordenação Ministério do Meio Ambiente.

O Capítulo 4 apresenta a metodologia do modelo integrado de equilíbrio (MEI) utilizado no presente trabalho para calcular as emissões do SIN para o período entre 2008-2017 e estimar os fatores de substituição ou linha de base de projetos candidatos ao MDL a serem conectados a sistemas elétricos. Mostra também as vantagens $e$ as limitações do uso desse tipo de modelo para atender aos objetivos do trabalho e apresenta a validação dele, simulando seus resultados para o período entre 2004-2008. Compara esses resultados com os dados efetivamente realizados dos níveis de armazenamento dos reservatórios, preço e geração de energia elétrica das térmicas flexíveis que servem ao SIN.

O Capítulo 5 mostra o desenvolvimento do referencial metodológico proposto no presente trabalho, para calcular as emissões deslocadas pelas atividades de um projeto candidato ao MDL conectado a um sistema elétrico hidrotérmico, predominantemente hídrico, com base numa visão prospectiva do mix das fontes energéticas que, provavelmente, serão responsáveis pelo fornecimento da energia elétrica requisitada pelo mercado.

Apresenta, detalhadamente, o conceito e a aplicabilidade da metodologia, fornece os parâmetros a serem calculados e os procedimentos para a determinação da linha de base prospectiva de sistema elétrico interligado, pelo cálculo das emissões totais anuais e para horizonte do estudo, na configuração de base.

Na seqüência, apresenta os procedimentos para estimar as emissões deslocadas pelas atividades do projeto MDL, calculando o Fator de Substituição de Emissão (FS) associado ao deslocamento da eletricidade fornecida pelas usinas térmicas convencionais existentes na configuração de base. Oferece ainda os critérios para determinar o risco associado ao Fator de Substituição, pelo cálculo do Fator de Substituição Descontado (FSD). 
Aplicação da proposta metodológica é feita no Capítulo 6, para estimar as emissões totais e as emissões por unidade de energia (MWh) do SIN, entre 2008 e 2017, em termos anuais e para o conjunto do período, a partir da configuração de base definida. Em seguida são apresentados os experimentos realizados para calcular os fatores de substituição do SIN após a entrada de quantidades de energias não emissoras e/ou reduções na demanda agregada, considerando a implementação de programas/medidas de eficiência energética. A última parte desse Capítulo discute os resultados encontrados, comparando com aqueles obtidos com a aplicação da ferramenta aprovada pelo Comitë Executivo (CE) do MDL e com os resultados apresentados em outros trabalhos.

No Capítulo 7 são apresentadas as Conclusões, Limitações e Recomendações do trabalho, seguido das Referências Bibliográficas e das Referências Consultadas, dos Apêndices e dos Anexos. 


\section{Capítulo 2 Aquecimento global: vulnerabilidades e políticas de mitigação no contexto do pós-2012}

Neste Capítulo são apresentadas as principais conclusões do Quarto Relatório de Avaliação do IPCC e do Relatório Stern, relativamente às vulnerabilidades e medidas de adaptação e mitigação das emissões dos GEE. Fornece ainda um panorama das expectativas sobre o comportamento mundial das emissões nas próximas décadas e dos custos para reduzir as emissões. O Capítulo 2 é finalizado com uma discussão sobre as expectativas e propostas para o pós2012, ano que se encerra o primeiro período do Protocolo de Kyoto, com base nas informações, cenários e análises desenvolvidas pela IEA (2008).

\subsection{A guisa de introdução}

Apesar do reconhecimento de que o aquecimento global provocado pelas emissões antrópicas é um problema grave, que precisa ser enfrentado urgentemente, sob pena de que sérios desequilíbrios climáticos possam ocorrer, sobretudo a partir da segunda metade do século XXI, uma questão de natureza ética se coloca preliminarmente: deve-se fazer alguma coisa em relação às mudanças climáticas ${ }^{33}$

A resposta a essa pergunta depende da avaliação que fazem as pessoas, os segmentos sociais e os governos nacionais em relação ao preço que se deve pagar, para assegurar que as gerações futuras não sejam vítimas dos danos causados pelo aquecimento global. Ainda que não se pretenda que assuntos de natureza ética alcancem amplos consensos, aparentemente, está prevalecendo, em nível global o princípio ético de que é necessário reduzir as emissões dos

\footnotetext{
${ }^{33}$ - Sobre a reflexão da questão ética envolvida na decisão do que, como e quanto gastar para reduzir o perigo de mudanças climáticas consideradas perigosas para o planeta são importantes os trabalhos de BROOME, 2006; MONBIOT, 2006; WEITZMAN, 2007.
} 
GEE e compensar as pessoas que já foram prejudicadas com as mudanças climáticas provocadas pelo aquecimento global (BROOME, 2008).

Portanto, considerando que há hoje um entendimento majoritário mundial, que aponta para a necessidade de que ações rápidas e eficazes sejam implementadas para combater as mudanças climáticas provocadas pelas atividades humanas, mais três outras questões se colocam:

a) Quanto custa e como estabilizar os gases de efeito de estufa na atmosfera;

b) Como resolver os problemas políticos envolvidos na gestão da transição para uma economia de baixas emissões de carbono;

c) Como garantir que as sociedades possam adaptar-se às conseqüências das alterações climáticas que já não podem ser evitadas (STERN, 2008a).

\subsection{O que se sabe sobre os impactos das mudanças climáticas}

De acordo com as conclusões expostas no Relatório Stern, o custo de não agir rapidamente será muito mais alto para o mundo do que os custos envolvidos com a decisão global de transitar para uma economia baseada em baixas emissões de carbono. Ignorar as mudanças climáticas, ao longo das próximas décadas, alerta esse documento

poderá criar riscos de grandes perturbações da atividade econômica e social, neste e no próximo século, em uma escala semelhante àquela associada com as grandes guerras e à depressão econômica da primeira metade do século 20. E será difícil ou impossível inverter estas mudanças (STERN, 2008b ${ }^{34}$, p.vi, tradução nossa).

Além disso, o texto do relatório aponta para o fato de que as ações pródescarbonização, não se conflitam com os objetivos de crescimento econômico

34 - Sumário de Conclusões 
dos países. Ao contrário, podem contribuir para novos e mais sustentáveis padrões de crescimento econômico para países pobres e ricos ${ }^{35}$.

Quanto menos ações os países implementarem hoje para mitigar e combater os efeitos das mudanças climáticas, maiores ou mesmo irreversíveis serão os efeitos dessas mudanças sobre o futuro da humanidade. Nesse sentido, chama a atenção para o fato de que a continuidade do cenário atual, em termos dos fluxos de emissões dos GEE, poderia levar a que a temperatura do planeta aumentasse acima dos $5^{\circ} \mathrm{C}$, até o final do século 21 , com conseqüências desconhecidas para a humanidade (STERN, 2008b).

O relatório Stern destaca ainda que as atuais concentrações dos GEE sejam equivalentes a $430 \mathrm{ppm}$ de $\mathrm{CO}_{2}$-eq. Esse nível de concentração já causou uma elevação da temperatura da Terra em $0,5^{\circ} \mathrm{C}$ e levará, por inércia, a que mais meio grau de temperatura ocorra nas próximas décadas (STERN, 2008a).

Além disso, estima que se as atuais taxas de aumento das concentrações dos GEE forem crescentes, o estoque de gases de efeito estufa na atmosfera atingiria, já em 2035, 550 ppm $\mathrm{CO}_{2}$-eq, o dobro dos níveis pré-industriais e continuaria a crescer depois. Mantidas as atuais tendências a média global da temperatura crescerá entre 2 e $3^{\circ} \mathrm{C}$ nos próximos 50 anos, tomando-se por base os níveis de temperatura registrados no período pré-industrial, entre 1750 - 1850 (Ibid.).

De acordo com as informações publicadas no Quarto Relatório de Avaliação do IPCC (2007), entre 1970 e 2004, as emissões globais de todos os GEE, ponderadas pelo seu potencial de aquecimento global, aumentaram em $70 \%$, passando de 28,7 para $49 \mathrm{GtCO}_{2}$-eq. (IPCC, 2007a)

Ressalte-se que só entre 1990 e 2004 esse aumento foi de $24 \%$. O setor de oferta de energia liderou essa elevação, com 145\%, entre 1970 e 2004, seguindo-se pelo setor de transporte, com $120 \%$, da indústria, com $65 \%$ de

\footnotetext{
35 - Sobre o financiamento internacional para a transição para uma economia low carbon ver estudo desenvolvido por WATSON, R.(2007) para o Banco Mundial.
} 
elevação de suas emissões e do uso e mudança do uso da terra e florestas, com $45 \%$ (lbid.).

O efeito nas emissões globais da redução da intensidade do uso global de energia, de 33\%, entre 1970 a 2004 foi menor do que "o efeito combinado do aumento da renda global (77\%) e do crescimento da população global (69\%), ambos geradores das crescentes emissões de $\mathrm{CO}_{2}$ relacionadas com a energia" (IPCC, 2007b, p.4, tradução MCT).

Do ponto de vista das conseqüências das mudanças climáticas que já estão ocorrendo e que deverão se aprofundar em nível global caso medidas de mitigação das emissões não forem efetivamente implementadas, segundo o Relatório Stern (2008a, p. vi), destacam-se:

- Aumento do risco de inundações e redução do suprimento de água pelo degelo dos glaciares, sendo esperados impactos negativos sobre os povos que vivem no subcontinente indiano, partes da China e nos Andes;

- Redução da produtividade das culturas, especialmente na África, o que pode deixar centenas de milhões de pessoas sem a capacidade de produzir ou comprar comida suficiente. Em médias e altas latitudes, as colheitas podem aumentar se a temperatura subir moderadamente. Acima de $4^{\circ} \mathrm{C}$ a produção global de comida será seriamente afetada;

- A elevação de doenças como malária e dengue podem se tornar mais generalizadas em latitudes mais elevadas, pela elevação da temperatura;

- O aumento do nível do mar, prevendo-se que grandes inundações afetarão dezenas e até centenas de milhões de pessoas, com aquecimento de 3 ou $4^{\circ} \mathrm{C}$. Segundo algumas estimativas, em torno de 200 milhões de pessoas, até meados do século, podem se tornar permanentemente deslocadas devido a subida do nível do mar, grandes inundações e períodos de seca mais intensos;

- Espera-se também que os ecossistemas marinhos sofram efeitos negativos importantes com a acidificação oceânica, que resulta diretamente do aumento dos níveis de dióxido de carbono. Entre 15 a 40\% 
das espécies estarão, potencialmente, ameaçadas de extinção, caso a temperatura seja elevada em apenas $2^{\circ} \mathrm{C}$.

$\mathrm{Na}$ Figura 1 os efeitos esperados sobre produção de alimentos, disponibilidade de água, ecossistemas, alimentos, litoral e saúde em função da elevação da temperatura média do planeta, elaborada pelo Grupo II do IPCC, 2007.

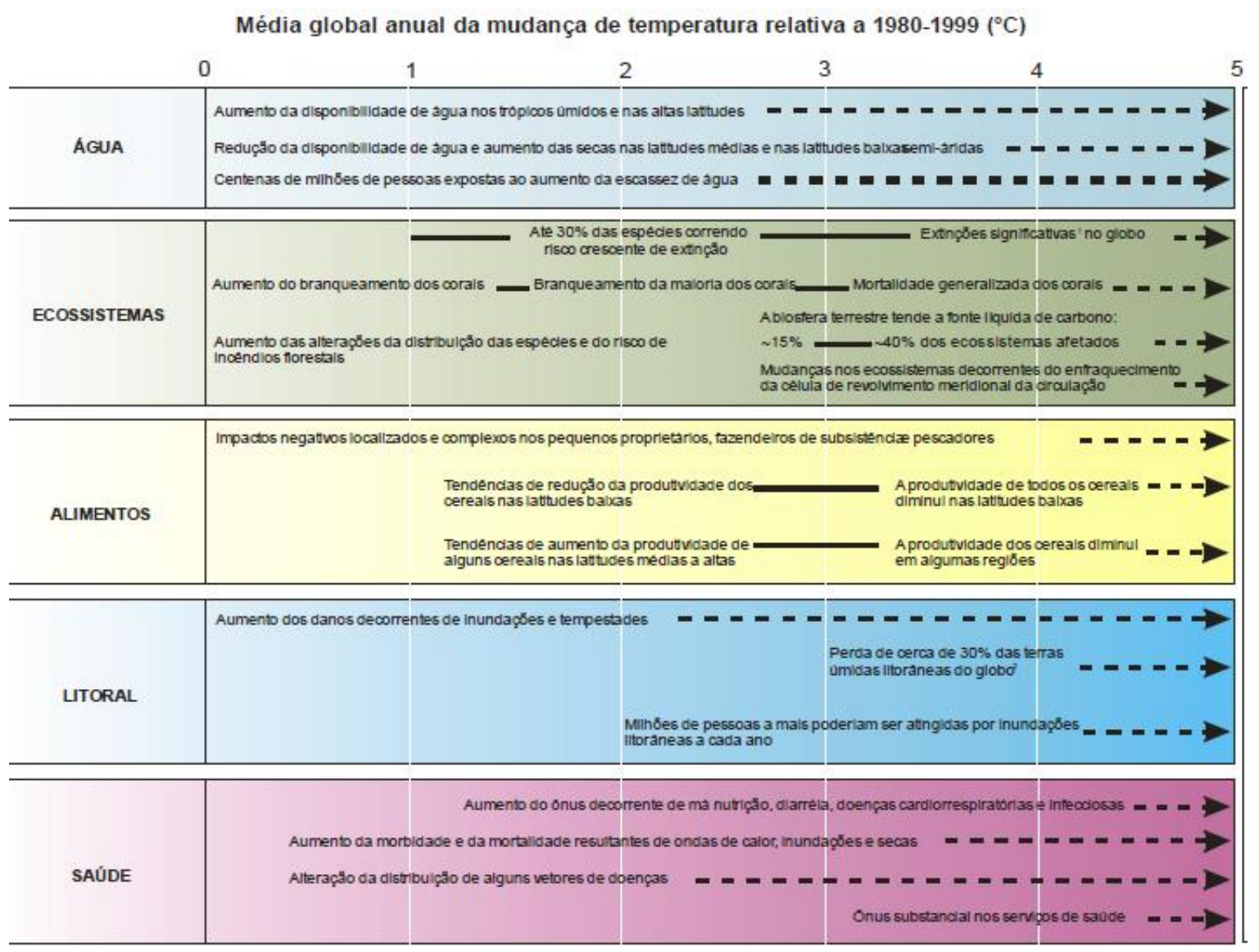

Figuras 1 - Principais impactos em função da elevação da temperatura global média Fonte: IPCC, 2007c (tradução MCT)

Embora a identificação do rebatimento das mudanças climáticas em nível regional seja mais difícil, o relatório Stern ressalta a possibilidade de que as mudanças climáticas afetem fenômenos naturais regionais, como as chuvas de monções no sul da Ásia e o El Niño, trazendo graves conseqüências para a disponibilidade hídrica, maiores inundações nas regiões tropicais, ameaçando a vida de milhões de pessoas. Estudos sugerem ainda que a floresta amazônica venha a se tornar vulnerável às alterações climáticas, com alguns modelos projetando secagem significativa nesta região. 
Além disso, como os impactos do aquecimento global são desigualmente distribuídos, eles afetariam de forma mais significativa e mais rapidamente os países e as populações mais pobres, que sabidamente possuem baixa capacidade de resposta e de adaptação às alterações climáticas (STERN, 2008a).

Destaque-se que apesar da implementação de uma série de políticas, visando combater as mudanças do clima para garantir a segurança energética e incentivar o desenvolvimento sustentável, muitas das quais têm sido eficazes na redução das emissões de gases de efeito estufa, elas não foram ainda suficientes para evitar o aumento das emissões globais nas quantidades necessárias para que sejam evitadas mudanças climáticas perigosas à manutenção do equilíbrio energético do planeta.

Nessas condições, para enfrentar alguns desses fenômenos que já estão ocorrendo, restam apenas aos governos e à sociedade discutir e identificar os caminhos para mitigar as emissões dos GEE, buscar as soluções para adaptarse e evitar que eventos mais graves e irreversíveis venham a ocorrer nas próximas décadas.

De acordo com os cenários do Relatório Especial sobre Cenários de Emissões $\left(\right.$ RECE) ${ }^{36}$ do IPCC, Gráfico 7, que não consideram políticas adicionais de mitigação ao longo do período da projeção, são estimadas elevações das emissões dos GEE na faixa de 9,7 $\mathrm{GtCO}_{2}$-eq a 36,7 $\mathrm{GtCO}_{2}$-eq, entre 2000 e 2030. Em todos os cenários

projetam-se que os combustíveis fósseis mantenham sua posição dominante na matriz energética global até 2030 e posteriormente" e que [...] "dois terços a três quartos desse aumento das emissões de $\mathrm{CO}_{2}$ relacionadas com a energia sejam provenientes das regiões não-Anexo I (IPCC, 2007b, p.5).

${ }^{36}$ - Os cenários do RECE não envolvem iniciativas adicionais em relação ao clima, o que significa que nenhum cenário adota explicitamente a implementação da Convenção-Quadro das Nações Unidas sobre Mudança do Clima ou as metas de redução de emissões do Protocolo de Kyoto. 


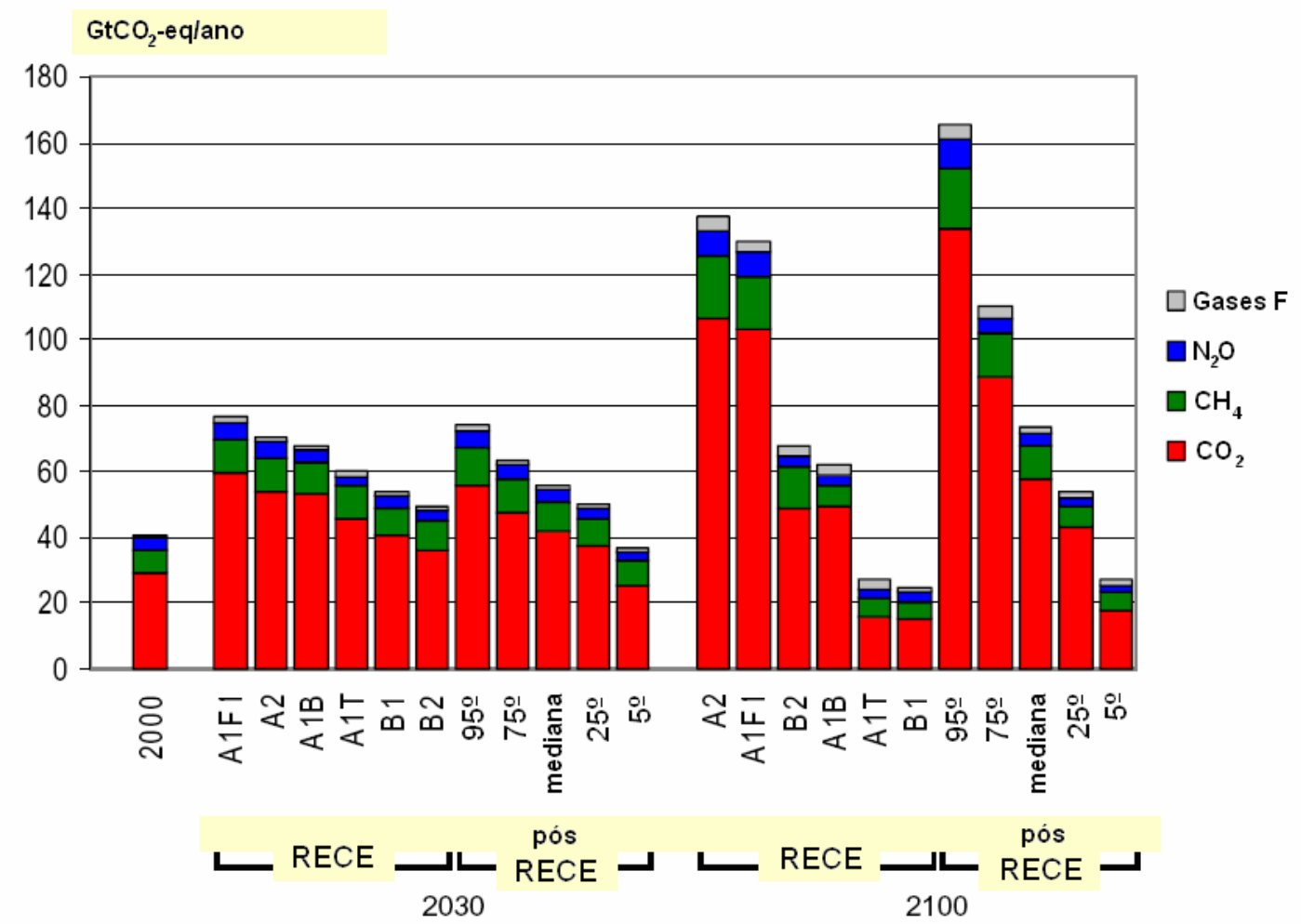

Gráfico 7 - Emissões antropogênicas mundiais dos GEE. Cenários RECE e Pós- RECE ${ }^{37}$ Fonte: IPCC, 2007b, p.9

Observe-se que de acordo com os cenários RECE, em 2030, as emissões globais de todos os GEE, serão, no mínimo, 24\% superiores àquelas registradas no ano 2000, podendo quase duplicar, se a trajetória de crescimento das emissões se comportasse conforme prevê o cenário $A 1 F 1^{38}$. As projeções dos cenários pós- RECE, considerando os valores da mediana, as emissões globais seriam $37 \%$ superiores aquelas registradas em 2000.

Em 2100, a expectativa é de que, em pelo menos em dois cenários - A1T e B1 as emissões totais sejam significativamente inferiores àquelas registradas no ano 2000. Cabe destacar, no entanto, que nos cenários pós - RECE projetam-se crescimento significativo e continuado das emissões para 2030 e para 2100 , exceto para o $5^{\circ}$ percentil.

\footnotetext{
37 - Pós - RECE refere-se aos cenários encontrados na literatura, projetados após a publicação do Terceiro Relatório de Avaliação (TRA) do IPCC, em 2001.

${ }^{38}$ - Ver no Anexo A - Quadro SFP 1, a descrição das principais características e premissas adotadas para a construção desses cenários
} 
No cenário de referência projetado pela IEA (2008) as emissões totais dos GEE são estimadas para aumentarem $35 \%$, de $44,2 \mathrm{Gt} \mathrm{CO}_{2}$-eq para $56,6 \mathrm{Gt} \mathrm{CO}_{2}$-eq em 2030. Observe-se que esse cenário, o cenário B1 do RECE e o cenário representado pela mediana do pós-RECE (Gráfico 7) projetam para 2030

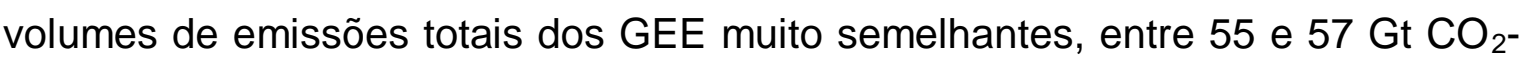
eq.

\subsection{Mitigação e custos da estabilização das concentrações dos GEE na atmosfera}

Estimar os custos e riscos associados às mudanças climáticas e estabelecer a relação custo/beneficio são instrumentos que embora não respondam sobre o que a sociedade deve fazer para mitigar as mudanças climáticas é uma parte importante da resposta.

Muitos desses custos e benefícios podem ser mensurados com razoável grau de acerto, mesmo para situações muito complexas. Buscando mensurar e avaliar os custos das mudanças climáticas sobre o PIB mundial e identificar co-benefícios associados a ações e medidas para mitigar os efeitos dessas mudanças, em médio e longo prazo o Relatório Stern e o $4^{\circ}$ Relatório de Avaliação do IPCC apresentaram uma vasta gama de informações e análises, a partir das quais se tornou possível um entendimento mais abrangente sobre o assunto.

Custos e co-benefícios segundo o Relatório Stern

Partindo da premissa de que embora não seja possível predizer com absoluta certeza quais as conseqüências das mudanças climáticas no futuro, o Relatório Stern observa que existe na atualidade conhecimento suficiente para avaliar os riscos inerentes a essas mudanças. Mais: reconhece que os efeitos das ações 
realizadas no presente têm apenas uma pequena repercussão sobre o clima nos próximos 40 a 50 anos. No entanto, afirma que a não ação nos próximos 10 a 20 anos pode ter um profundo e negativo efeito sobre o clima, sobretudo a partir da segunda metade do século XXI.

A idéia central é que ações fortes e rápidas para mitigar os efeitos do aquecimento global devem ser vistas não como custos, mas sim como investimento. Ou seja, o custo incorrido no presente e nas próximas décadas poderá evitar o risco de severas conseqüências relacionadas aos desequilíbrios climáticos, no futuro. Observa ainda que se os investimentos forem feitos desde já, eles são gerenciáveis e viáveis, na medida em que possibilitam também novas oportunidades de negócios, emprego e renda, promovendo crescimento econômico e desenvolvimento social.

De acordo com as estimativas do Relatório Stern, a estabilização das concentrações atmosféricas em 550 ppm de $\mathrm{CO}_{2}$-eq exigiria que as emissões globais atingissem um pico nos próximos 10 a 20 anos, caindo depois a um ritmo de pelo menos 1 a 3\% ao ano. Em 2050, as emissões globais teriam de se situarem $25 \%$ abaixo dos níveis atuais (STERN, 2008a).

Para estabilizar em $450 \mathrm{ppm} \mathrm{CO}_{2}$-eq, as emissões globais atingiriam um pico nos próximos 10 anos, caindo depois em mais de $5 \%$ ao ano, até alcançarem, em 2050, níveis $70 \%$ inferiores aos atualmente registrados. O relatório destaca ainda que os cortes terão de ser feitos no contexto de um mundo cuja economia, em 2050, poderá ser 3 a 4 vezes maior do que é hoje (STERN, 2008a).

Nesse mesmo sentido, de acordo com as análises e cenários projetados pelo IEA (2008a), caso não sejam adotadas urgentes medidas de redução das emissões dos GEE as concentrações do dióxido de carbono na atmosfera dobrarão, passando de 380 ppm em 2005 para 700 ppm no final do século XXI. Considerando todos os GEE, a não ação levaria o nível das concentrações para 1000 ppm de $\mathrm{CO}_{2}$-eq, com estimativa de elevação da temperatura do Planeta em $6^{\circ} \mathrm{C}$. As ações de mitigação no setor energético, que atualmente é responsável 
por $61 \%$ das emissões dos GEE, serão fundamentais para que até 2030 , as concentrações dos GEE na atmosfera não ultrapassem 450 ppm ou 550 ppm.

Stern destaca ainda que, apesar do grande volume de cortes necessários, o custo de uma ação forte e rápida custaria, anualmente, algo em torno de $1 \%$ do PIB mundial, até 2050. Revelou também que, se essas medidas para reduzir as emissões dos GEE não forem adotadas desde já, a implementação delas mais adiante não produziria os efeitos desejados para garantir os níveis de concentração dos GEE entre 450 e 550 ppm, em 2050, ou, no limite, a não ação poderia levar o Planeta a experimentar mudanças climáticas irreversíveis.

Anuncia o relatório:

Utilizando os resultados de modelos econômicos formais, a análise
estima que, se não agirmos, os custos globais e os riscos das
alterações climáticas será equivalente à perda de pelo menos $5 \%$ do
PIB mundial por ano, agora e sempre. Levando-se em conta uma gama
mais vasta de riscos e impactos, as estimativas de danos poderão
atingir $20 \%$ do PIB ou mais (STERN, 2008b, p. vi, tradução nossa).

E vai mais adiante: considera que é indispensável que a ação seja forte, global e baseada em uma visão em acordos e metas de longo prazo compartilhadas, criando, dessa forma, efeitos sinergéticos entre as ações em nível nacional, regional e internacional.

Como algumas mudanças são inevitáveis que ocorram nas próximas duas a três décadas, o Relatório sugere melhorar as informações, o planejamento e a infraestrutura. Se cada país tentar resolver individualmente mais recursos serão necessários investir e mais pressão trará sobre os recursos a cada dia mais escassos (STERN, 2008b).

As mudanças climáticas apesar de afetarem todos os países são muito mais impactantes nos países mais pobres, tendo em vista a reduzida capacidade de resposta que esses países possuem para adotarem medidas para superar os efeitos das mudanças climáticas e minimizar custos (lbid.) 
Os elementos-chave do futuro quadro internacional incluem ações fortes para alargar o comércio de emissões em todo o mundo, redirecionando os fluxos dos recursos oriundos desse comércio para apoiar a transição dos países em desenvolvimento para uma economia de baixa emissão; intensificar a cooperação tecnológica para aumentar a eficácia dos investimentos em inovação em todo o mundo, sobretudo para incentivar a implantação de tecnologias com baixas emissões de carbono e que aumentem a eficiência energética; ampliar a gama de medidas para reduzir o desmatamento e, integrar as políticas de adaptação à política de desenvolvimento dos países (STERN, 2008b)

Custos e co-benefícios segundo o Relatório de Avaliação do Grupo III de IPCC

Segundo o Relatório do Grupo III do IPCC (2007b), para estabilizar as concentrações dos GEE na atmosfera em 450 ppm de $\mathrm{CO}_{2}-$ eq, emissões teriam que atingir um pico nos próximos anos e cair, sistematicamente, a um média anual de $6 \%$ ou mais. Para se ter uma idéia do tamanho desse esforço, as emissões per capita médias mundiais teriam que cair das atuais $7 \mathrm{tCO}_{2}$-eq para 2 toneladas por volta de 2050. Isso significaria que em 2050 as emissões registrariam uma queda de 50 e 85 \%, em relação aos níveis observados no ano 2000.

O IPCC, partindo do conceito de potencial de mitigação desenvolvido para avaliar a escala das reduções dos GEE que poderiam ser feitas, calculou o potencial de redução das emissões, considerando o potencial de mercado e o potencial econômico. O primeiro foi avaliado com base nos custos e nas taxas de retorno privadas e o segundo com base nos custos e benefícios e nas taxas de retorno sociais, supondo que a eficiência do mercado melhore com a implementação de políticas e medidas e que as barreiras sejam removidas. Os potenciais de 
mercado e econômico foram calculados com base nas abordagens top-down e bottom-up ${ }^{39}$.

Os modelos usados pelo IPCC para avaliar o potencial de mitigação assumiram as seguintes premissas:

$\checkmark$ Menor custo para os portfólios de mitigação;

$\checkmark$ Livre comércio global de emissões;

$\checkmark$ Implementação perfeita das medidas de mitigação ao longo do século XXI.

Esses modelos não consideram os benefícios climáticos nem os co-benefícios das medidas de mitigação ou as questões de eqüidade.

Os Gráficos 8a e 8b apresentam os resultados encontrados da relação entre o custo e o potencial estimado de mitigação com o uso das abordagens bottom-up e top-down, respectivamente.

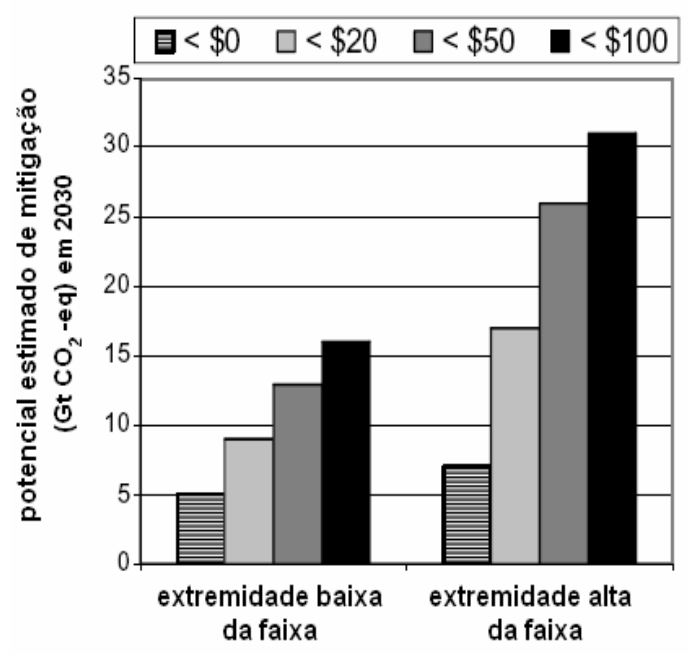

Gráfico 8a- Potencial Estimado Abordagem bottom-up

Fonte: IPCC, 2007b, p.15

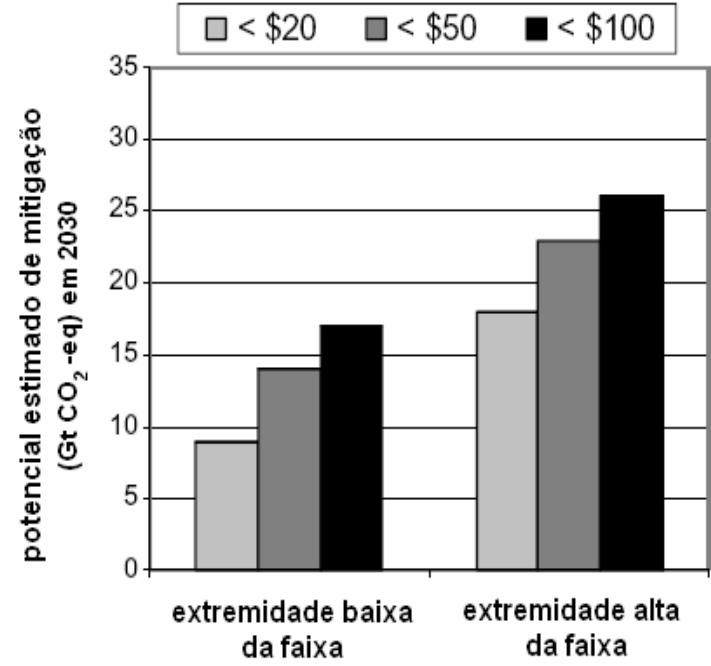

Gráfico 8b- Potencial Estimado Abordagem top-down

Fonte: IPCC, 2007b, p.15

${ }^{39}$ - Os estudos bottom-up são setoriais, baseados em opções tecnológicas e em regulamentações específicas. Os estudos top-down usam quadros globais e informações agregadas sobre as opções de mitigação. (IPCC, 2007c) 
Os resultados dos estudos mostram que, qualquer que seja a abordagem considerada, há um significativo potencial econômico global de mitigação dos GEE, ao ponto de afirmar-se que, a depender da eficácia no aproveitamento desse potencial, o crescimento esperado das emissões dos GEE nas próximas décadas poderia ser mais do que compensado pelas reduções provenientes das ações de mitigação.

Fica claro também que a um custo menor do que $\$ 20$, mesmo para as extremidades baixas das faixas, o potencial de mitigação é de quase $10 \mathrm{Gt} \mathrm{CO}_{2}-$ eq, em 2030. A um custo de até $\$ 50$, esse potencial poderá atingir volumes de mais de $15 \mathrm{GtCO}_{2}$-eq. Para as extremidades altas das faixas, os potenciais de mitigação seriam de pouco mais de $17 \mathrm{tCO}_{2}-\mathrm{eq}$, para custo menor do que $\$ 20$ e entre $23 \mathrm{GtO}_{2}$-eq e pouco mais de $25 \mathrm{GtO}_{2}$-eq, para as duas abordagens, com custo até $\$ 50$

Atualmente inúmeras tecnologias se encontram disponíveis, com mais desenvolvimentos esperados até 2030, que podem ou poderão ser aplicadas para mitigar as emissões dos GEE em diversos setores da economia mundial.

Os potenciais de mitigação por região e setor, como função do preço do carbono em 2030, com base em estudos bottom-up, em relação às respectivas linhas de base adotadas nas avaliações do setor são apresentados na Figura 2.

Observe-se que o maior potencial para a aplicação de medidas de mitigação encontra-se no segmento de edificações, entre 5,3 e 6,7 $\mathrm{GtCO}_{2}$-eq/ano, indicando mais uma vez a importância das políticas e medidas de eficiência energética para combater o aquecimento global ${ }^{40}$.

Como as alocações dos potenciais de mitigação foram feitas pelo uso final das emissões, as emissões do uso de eletricidade foram contabilizadas nos setores de uso final e não no setor de oferta de energia. Para estimar o potencial de

\footnotetext{
40. Recentes estudos desenvolvidos por Figueras e Philips (2007), Hinostroza, et al., (2007) mostram também a importância e o baixo custo, na comparação com outras iniciativas, das ações de eficiência energética e conservação para reduzir as emissões dos GEE. Esses estudos recomendam que sejam adotados novos procedimentos com vistas a reduzir os custos e facilitar a implementação desse tipo de projeto, no âmbito do MDL.
} 
mitigação dos setores foram usadas diversas linhas de base associadas aos cenários do RECE, exceto para a oferta de energia e transporte, para os quais a linha de base utilizada foi a do WEO (2004).

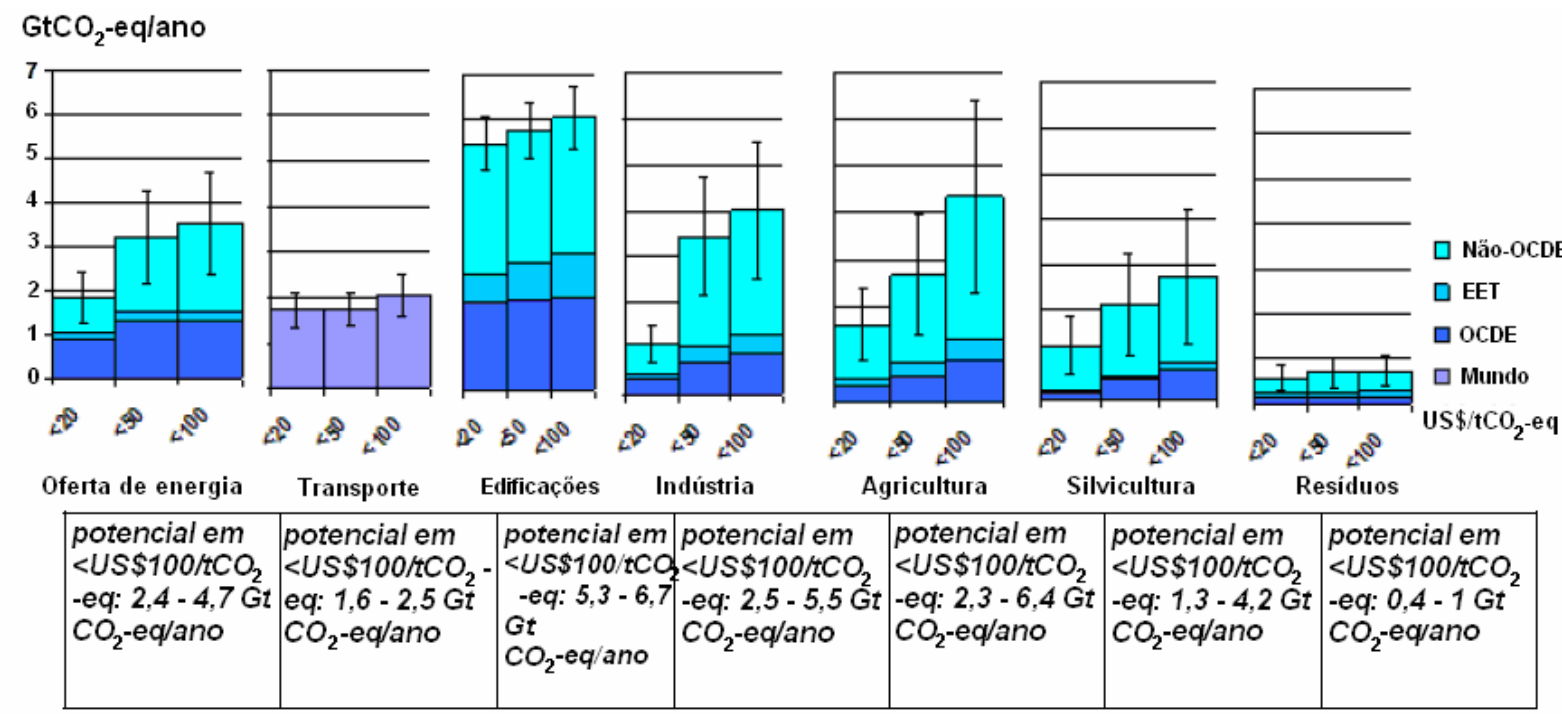

Figura 2 - Potencial de mitigação por região e setor Fonte: IPCC, 2007b, p.18 (tradução nossa)

Os custos para 2030, considerando as trajetórias de emissões de 445 e 710 ppm $\mathrm{CO}_{2}-\mathrm{eq}$, são estimados em um intervalo entre 3\% do PIB global e um pequeno aumento, em relação a linha de base. Na Tabela 4 encontram-se as reduções esperadas do PIB global associadas aos diferentes níveis de estabilização em longo prazo.

Tabela 4 - Custos macroeconômicos globais estimados para 2030

\begin{tabular}{cccc}
\hline $\begin{array}{c}\text { Níveis de } \\
\text { estabilização } \\
\left(\mathrm{ppm} \mathrm{CO} \mathrm{CO}_{2} \text {-eq) }\right.\end{array}$ & $\begin{array}{c}\text { Redução média } \\
\text { do PIB } \\
(\%)\end{array}$ & $\begin{array}{c}\text { Faixa de redução } \\
\text { do PIB } \\
(\%)\end{array}$ & $\begin{array}{c}\text { Redução das taxas anuais médias de } \\
\text { crescimento do PIB } \\
\text { (pontos percentuais) }\end{array}$ \\
\hline $590-710$ & 0,2 & $-0,6-1,2$ & $<0,06$ \\
$535-590$ & 0,6 & $0,2-2,5$ & $<0,1$ \\
$445-535$ & Não disponível & $<3$ & $<0,12$ \\
\hline
\end{tabular}

Fonte: IPCC, 2007b, p.19

É importante destacar que os custos estimados pelos modelos podem ser significativamente menores, segundo o próprio relatório do IPCC, a depender do sistema fiscal existente e do perfil de gastos das receitas. Se, por exemplo, as receitas provenientes de impostos de carbono e licenças leiloadas forem usadas 
para promover tecnologias de baixa emissão de carbono ou, se forem destinadas a reformar os impostos existentes isto ajudará a reduzir os custos da mitigação.

Fundamental também será promover uma ampla revisão sobre os atuais padrões de consumo, por meio de difusão de uma nova cultura, que priorize a conservação dos recursos por meio da implementação de programas de eficiência energética e do planejamento urbano, que são elementos de base para a construção de uma nova economia descarbonizada.

Além disso, os estudos vislumbram a possibilidade de que um grande incentivo ao uso de tecnologias low carbon, induzam a uma grande mudança tecnológica que por seu turno gerariam custos mais baixos no futuro, ainda que isso signifique maiores investimentos no presente.

$\mathrm{Na}$ Figura 3 são apresentadas as reduções cumulativas de emissões para medidas alternativas de mitigação entre 2000 a 2030 (painel à esquerda) e 2000 a 2100 (painel à direita). Nesta Figura são apresentados os cenários ilustrativos de quatro modelos (AIM, Image, IPAC e Message), visando à estabilização em níveis para o intervalo entre 490 - 540 ppm $\mathrm{CO}_{2}$-eq e $650 \mathrm{ppm} \mathrm{CO}_{2}$-eq, respectivamente. As barras escuras denotam reduções para uma meta de 650 ppm $\mathrm{CO}_{2}$-eq e as barras claras, as reduções adicionais para que se atinja o nível de 450 - 540 ppm $\mathrm{CO}_{2}$-eq. 


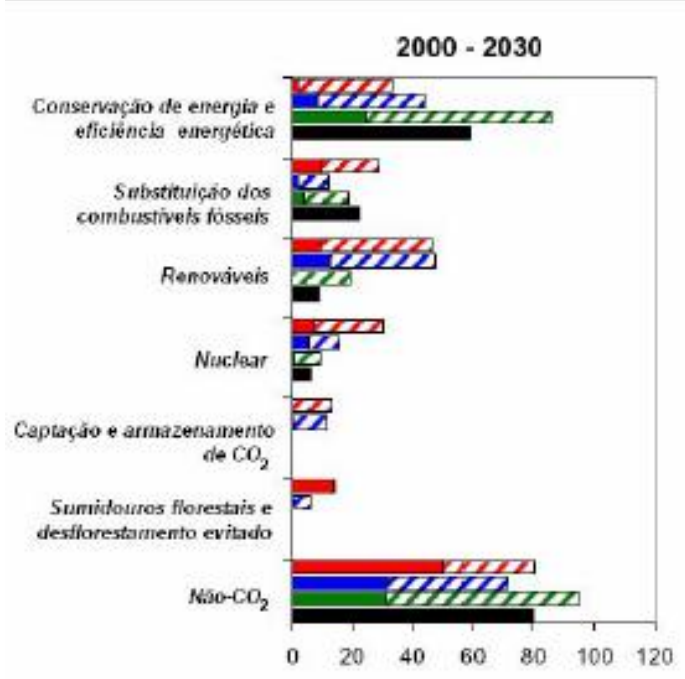

Reduçōes cumulativas de emisso̊es (2000-2003), $\mathrm{GtCO}_{2}$

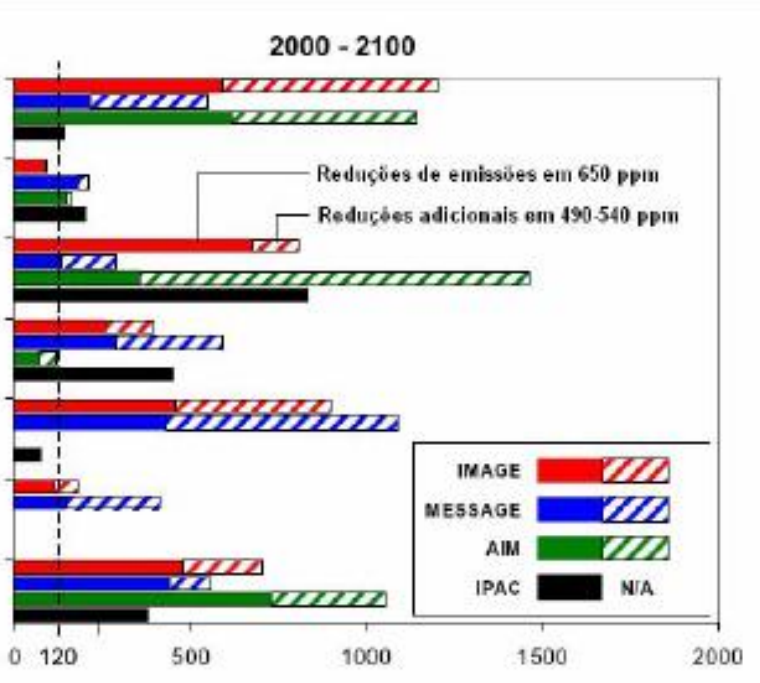

Reduçöes cumulativas de emissões $(2000-2100), \mathrm{GtCO}_{2}$

Figura 3 - Reduções cumulativas de emissões estimadas por tipo de projeto em quatro modelos Fonte: IPCC, 2007b, p.31 (tradução nossa)

O IPCC estimou que os custos globais para mitigar as emissões dos GEE, considerando uma meta de redução entre 445 e 710 ppm CO CO $_{2}$ eq, em 2050, variando entre uma redução de $5,5 \%$ do PIB mundial a um ganho de $1 \%$ desse mesmo agregado. Essas variações dos custos econômicos em função dos níveis de concentrações atmosféricas admitidas são apresentadas na Tabela 5.

Observe-se, no entanto, que a avaliação dos custos e dos benefícios associados à mitigação depende do modo como é projetada a curva de custos da mitigação. Assim, se a curva desses custos cresce lenta e regularmente, uma mitigação posterior e menos rigorosa será economicamente justificável; se, ao contrário, a curva de custo do dano aumentar brusca e irregularmente, por exemplo, apresentar patamares de vulnerabilidade ou pequenas probabilidades de eventos catastróficos, uma mitigação mais cedo e mais rigorosa será economicamente justificável (IPCC, 2007b).

Portanto a tomada de decisão sobre o nível adequado da mitigação é um processo que envolve gestão de risco, visando equilibrar "os custos econômicos de reduções mais rápidas de emissões no presente com os correspondentes riscos climáticos em médio e longo prazo decorrentes da demora" (IPCC, 2007b, p. 32). 
Tabela 5 - Custos macroeconômicos globais estimados em 2050 para trajetórias de menor custo

\begin{tabular}{cccc}
\hline $\begin{array}{c}\text { Níveis de } \\
\text { estabilização } \\
\text { (ppm } \mathrm{CO}_{2} \text {-eq) }\end{array}$ & $\begin{array}{c}\text { Redução média } \\
\text { do PIB } \\
(\%)\end{array}$ & $\begin{array}{c}\text { Faixa de redução } \\
\text { do PIB } \\
(\%)\end{array}$ & $\begin{array}{c}\text { Redução das taxas anuais } \\
\text { Médias de crescimento do PIB } \\
\text { (pontos percentuais) }\end{array}$ \\
\hline $590-710$ & 0,5 & -1 a 2 & $<0,05$ \\
$535-590$ & 1,3 & levemente negativa a 4 & $<0,1$ \\
$445-535$ & não disponível & $<5,5$ & $<0,12$ \\
\hline
\end{tabular}

Fonte: IPCC, 2007b, p.32

É extenso e diversificado o rol de políticas e instrumentos que podem ser utilizadas pelos governos para incentivar as medidas de mitigação. A aplicação dessas políticas, no entanto, depende das especificidades nacionais e do modo como as forças sócio-econômicas, políticas e culturais interagem nos processos decisórios públicos e privados dos países. No entanto, qualquer que sejam as circunstâncias nacionais a aplicação das políticas e instrumentos para a mitigação devem atender aos seguintes critérios ${ }^{41}$ :

- Eficácia ambiental;

- Eficácia em relação aos custos;

- Efeitos de distribuição, inclusive a eqüidade;

- Viabilidade institucional.

A observância da aplicação desses critérios na formulação das políticas e na criação dos instrumentos elevará o grau de sustentabilidade e eficácia das medidas e ações implementadas.

41. Esses critérios foram estabelecidos com base na experiência internacional acumulada. Mais detalhes são encontrados no Relatório de Avaliação do Grupo II do IPCC, 2007 (IPCC, 2007c). 


\subsection{0 efeito mitigador das OPORTUNIDADES sobre os custos da mitigação}

Desde a realização da Conferência do Clima, em 1992, o tema da mudança do clima vem experimentando sucessivos avanços, tanto do ponto de vista científico, cuja síntese mais abrangente se encontra nas publicações elaboradas nos quatro relatórios de avaliação publicados pelo IPCC, quanto do ponto de vista político, materializadas na Convenção-Quadro das Nações Unidas para a Mudança do Clima - CQNUMC, na aprovação do Protocolo de Kyoto, em 1997 e nas reuniões e decisões assumidas pelos países reunidos em catorze COP, anualmente realizadas, desde 1994 .

Fruto desses esforços se consolidou, em nível mundial, a compreensão e a consciência de que as mudanças climáticas, que já estão ocorrendo e que poderão ocorrer com muito mais intensidade nas próximas décadas, representam uma séria ameaça para o equilíbrio energético do Planeta. A compreensão mais atualizada é a de que, se ações fortes e rápidas de mitigação não começarem a ser implementadas desde já, as conseqüências do aquecimento global poderão se tornar irreversíveis e catastróficas para a humanidade, até o final do século $\mathrm{XXI}$,

Com a publicação do Quarto Relatório de Avaliação do IPCC, em 2007 e do Relatório Stern, em 2008, foi dado mais um grande passo: à luz do conhecimento acumulado o mundo viu emergir a formulação de que opções de crescimento econômico e de bem-estar social não são incompatíveis com a implementação de políticas e ações para reduzir as emissões antrópicas dos GEE na atmosfera.

Ao contrário do que até muito recentemente se pensava, esses esforços podem ser convergentes, na medida em que, embora o processo de transição para uma economia com baixos níveis de emissões implique em pesados custos para a sociedade, poderão ser altamente recompensados pelos co-benefícios associados a esse processo de descarbonização. 
Os dois relatórios demonstram, com base em diversos estudos e cenários projetados, que não há mais como prescindir da mitigação e que os custos para reduzir as emissões serão tanto maiores quanto mais tempo os governos precisem para decidir e implementar as políticas de mitigação.

Com efeito, o entendimento atual indica que a implementação de ações rápidas e fortes para reduzir as emissões dos GEE criará oportunidades significativas de negócios para o comércio de bens e serviços de baixas emissões. Ou seja, crescimento econômico e reduções de emissões podem caminhar no mesmo sentido e não como decisões mutuamente excludentes. De acordo com essa visão as mudanças nas tecnologias energéticas e nos padrões de produção e consumo criarão essas novas oportunidades de negócios, com geração de renda e emprego, menos dependentes das emissões dos GEE. (STERN, 2008a).

Portanto, partindo-se da premissa de que o futuro não é determinado, ou por outra, que vários futuros são possíveis e a construção deles depende das ações que os indivíduos, grupos e segmentos sociais implementem no presente, a proposta de um novo tipo de desenvolvimento sócio-econômico, baseado em padrões de produção e consumo de baixas emissões dos GEE, reveste-se, sem dúvida, de uma enorme importância para o futuro da humanidade.

Até muito recentemente, mesmo para aqueles que percebiam com clareza os perigos das mudanças climáticas para o Planeta e que enxergavam que era urgente e necessário mitigar as emissões, não havia um entendimento sobre como combinar, adequadamente, descabonização e desenvolvimento econômico, sobretudo, para os países em desenvolvimento e os países mais pobres.

Ressalte-se que tudo isso só foi possível porque nos últimos anos ampliou-se, consideravelmente, o entendimento e os modelos desenvolvidos para quantificar os custos da mitigação e também os benefícios associados às novas opções de desenvolvimento econômico, sustentadas em tecnologias low carbon, na eficiência energética, na educação, na transferência de tecnologia dos países 
mais ricos para as nações em desenvolvimento e pobres, na educação, para a melhoria na qualidade e no padrão de consumo, no planejamento urbano eficaz, na melhoria de práticas agrárias e agrícolas, entre outras, que certamente produzirão efeitos benéficos reais e de longo prazo para o futuro dos povos.

No entanto, para que todos esses avanços realizados alcancem um novo patamar na luta para combater o aquecimento global, um amplo consenso político deverá ser construído em torno e das propostas para transição de uma economia baseada em altas emissões de carbono para modos de produção e consumo de baixas emissões. A COP15, que será realizada em Copenhagen, em dezembro de 2009, será um teste importante para definir a direção e a velocidade das mudanças necessárias.

\subsection{O pós- 2012: Como será?}

Em meio a um intenso processo de discussão sobre o que acontecerá no pós2012, ano que formalmente se encerra o primeiro período de compromisso do Protocolo de Kyoto, o balanço que os países estão fazendo sobre os resultados alcançados, certamente indicará mudanças nas bases sobre as quais será concebido um novo acordo mundial, nos compromissos que serão assumidos e nos instrumentos que serão utilizados para que os novos objetivos fixados sejam efetivamente realizados.

Em geral, constata-se que: primeiro, as metas estabelecidas no Protocolo de Kyoto são insuficientes para garantir reduções de emissões dos GEE nas quantidades necessárias para que o processo de aquecimento do planeta não represente uma séria e irreversível ameaça para a humanidade; segundo, que a posição dos EUA e dos países emergentes sobre a adoção de metas quantificadas é um ponto crucial para que seja possível o estabelecimento de políticas e ações fortes e rápidas para estabilizar as concentrações dos GEE na atmosfera entre 450 e 550 ppm até o final do século XXI; terceiro, que muitos 
países listados no Anexo 1, além da União Européia, cumpriram e até mesmo superaram, as metas estabelecidas, demonstrando que esse é um caminho viável e que, portanto, não deve ser abandonado, após 2012.

Nessas condições, assumindo-se a premissa de que é necessário mudar os atuais padrões de produção e consumo de mercadorias e serviços, fazendo uma rápida transição para uma economia de baixas emissões, as expectativas mais otimistas apontariam para o ano de 2012 como símbolo ou marco de uma grande virada global no sentido da implementação de políticas e ações baseadas em rotas de desenvolvimento e gestão dos recursos energéticos ambientalmente sustentáveis, socialmente justas e economicamente viáveis.

$\mathrm{Na}$ outra ponta, as posições mais pessimistas apontariam para 2012 como o ano em que o mundo pode decidir acabar. Ou seja, os países e setores sociais hegemônicos em nível mundial, anunciariam o fracasso do Protocolo de Kyoto e de outras iniciativas voluntárias para combater o aquecimento global. Além disso, não vislumbrariam alternativas para reduzir as emissões das concentrações dos GEE na atmosfera compatíveis com a estabilização dessas concentrações em níveis suportáveis para o equilíbrio energético da Terra.

Sob essa ótica, não restaria à humanidade senão esperar que uma imensa catástrofe climática se abatesse sobre o Planeta, ou "torcer" para que todas as evidências que apontam para uma crescente elevação das emissões antrópicas dos GEE, não se confirmassem ou não produzissem os efeitos negativos esperados em médio e longo prazo.

Extremos à parte, o mais provável é que o mundo chegue em 2012 com a população mais consciente e atenta para os riscos associados ao aquecimento global, com os EUA e os principais países em desenvolvimento integrados no esforço comum de redução das emissões dos GEE. Ainda é cedo para identificar as características e o perfil desse novo Acordo mundial. Tudo vai depender dos avanços que poderão ser conquistados na COP de Copenhagen. 
As análises desenvolvidas pela IEA (2008) mostraram que três questões nortearão os debates e decisões em Copenhagen: primeira, qual é a meta apropriada de redução das emissões dos GEE para as próximas décadas? Segunda, quais os mecanismos mais eficientes para atingir o(s) objetivo(s) acordado(s)? Terceira, que compromissos e ações cada país deve assumir que representem justos e equitativos resultados?

Na mesa um fato recente e positivo, que fortalece a posição dos países e setores sociais mais engajados na luta contra o aquecimento global: o novo posicionamento dos EUA, com a eleição de um presidente claramente favorável à redução da dependência energética do país ao petróleo. O outro fato, que é negativo do ponto de vista sócio-econômico, é a recessão da economia mundial que ao reduzir as pressões mais fortes sobre a demanda por energia contribuirá para reduzir as emissões dos GEE, pelo menos nos países mais desenvolvidos.

Mas é preciso deixar claro que nenhum deles poderá substituir a necessidade de um amplo e mais ambicioso acordo mundial para reduzir as emissões de forma coordenada em nível global e que seja localmente aplicável, considerando as circunstâncias e especificidades nacionais.

A discussão sobre a meta apropriada de redução das emissões

Não existe ainda um consenso internacional sobre o nível de estabilização que deve ser adotado e/ou mesmo sobre a trajetória a ser seguida para atingir essa estabilização. As discussões em nível internacional apontam para que esse nível se situe entre 450 ppm e 550 ppm de $\mathrm{CO}_{2}$-eq.

Em termos de emissões de $\mathrm{CO}_{2}$, as projeções da IEA (2008) ${ }^{42}$, comparadas com os cenários projetados pelo IPCC, 2007 apontam trajetórias de emissões médias, entre 2010 e 2030, um pouco abaixo das projeções do IPCC para níveis de

42 - Dados publicados pela IEA/ WEO, 2008, p.415. 
concentrações dos GEE de 450 e $550 \mathrm{ppm}$. Com efeito, enquanto o IPCC aponta emissões de 29,8 a 32,9 $\mathrm{GtCO}_{2}$, em 2010 e 2030, respectivamente o IEA (2008), considerando a média das dispersões de 21 cenários, quantifica um valor igual para 2010 e registra uma estimativa um pouco menor de, aproximadamente, 29 $\mathrm{GtCO}_{2}$, em 2030, para um cenário de níveis de concentrações atmosféricas dos GEE de 550ppm.

Para o cenário dos níveis de concentrações atmosféricas de 450 ppm, as projeções são as mesmas para 2010 e de $25,7 \mathrm{gtCO}_{2}$ estimadas pelo IPCC para 2030 e algo em torno de $23 \mathrm{GtCO}_{2}$, projetadas pelo IEA, em2008 (Ibid.).

Segundo estimativas elaboradas pela União Européia, para frear o aquecimento global serão necessários desembolsos da ordem de 507 bilhões de reais, algo em torno de 175 bilhões de euros a serem aplicados, anualmente, até 2020, para evitar que a temperatura média não ultrapasse o limite de $2^{\circ} \mathrm{C}$ acima da era préindustrial. Isso irá representar um esforço de corte das emissões em torno de 30\% abaixo dos níveis registrados em 1990, até 2020.

Com efeito, os cenários elaborados pela IEA (2008) de estabilização das emissões em 450 ppm e 550 ppm de $\mathrm{CO}_{2}$-eq, indicam que para atingir as suas respectivas metas será necessário realizar um grande esforço, envolvendo todos os países, em particular os cinco maiores emissores mundiais ${ }^{43}$, que juntos são responsáveis por $3 / 4$ das emissões globais de $\mathrm{CO}_{2}$. A China e os EUA são decisivos para o objetivo de estabilização nos dois cenários, participando com $21 \%$ e $20 \%$ das emissões globais em 2007 (IEA/WEO, 2008).

Além disso, a participação dos países não OCDE também deverá ser indispensável, na medida em que, de acordo com as projeções do cenário de referência elaborado pela IEA/WEO, 2008, em 2020, as emissões desses países representarão $62 \%$ das emissões globais de $\mathrm{CO}_{2}$ (IEA, 2008).

\footnotetext{
${ }^{43}$ - Países mais emissores em 2007: China (21\%), EUA (20\%), União Européia (14\%), Índia (4\%) e Rússia (6\%). A União Européia foi responsável por 14\% das emissões em 2007. No Cenário para 2020 os percentuais são: China (27\%), EUA (16\%), Índia (6\%) e Rússia (5\%). Para a União Européia prevê-se que a participação no total das emissões seja reduzida para 11\%. (IEA/WEO, 2008)
} 
Para se ter uma idéia da magnitude desse esforço, se a meta estabelecida for de 450 ppm em 2030, mesmo que os países da OCDE reduzissem suas emissões à zero, ainda assim, para que a meta fosse atingida, os países não OCDE teriam que reduzir suas emissões em relação ao cenário de referência (IEA, 2008, p. 418).

Além disso, os estudos desenvolvidos pela IEA (2008) mostram que para atingir as metas estabelecidas nos dois cenários um grande esforço de transformação das atuais tecnologias de geração de energia terá que ser realizado, requerendo, investimentos em larga escala no desenvolvimento de tecnologias de baixas emissões.

Essa transformação, no entanto, encontra dois grandes obstáculos: em primeiro lugar, devido ao fato de que isso só poderia ser feito com a demolição de substanciais estoques de capital existentes em toda a cadeia da indústria de energia, depois porque, dada à dimensão dos novos investimentos, é improvável que a produção dos novos equipamentos e a construção das infra-estruturas necessárias pudessem se realizar com rapidez suficiente para satisfazer a procura.

Como 75\% da geração de eletricidade no mundo em 2020 (e mais da metade em 2030) serão fornecidas por usinas que já se encontram hoje em operação, ainda que todas as novas plantas fossem construídas sem emissão de carbono, o $\mathrm{CO}_{2}$ do setor de energia seria apenas $25 \%$ menor em 2020 em relação ao cenário de referência (IEA, 2008).

A discussão sobre os princípios

$\mathrm{Na}$ medida em que se evidencia a necessidade de que as economias emergentes, como a China, Índia, países do Oriente Médio, México e Brasil, por 
exemplo, participem do esforço global de redução das emissões a questão que se coloca é a seguinte: como alocar as responsabilidades nacionais? Para a maioria dos analistas, esse é o grande desafio, que se coloca para a agenda de Copenhagen.

A IEA (2008) sistematizou da forma descrita abaixo, alguns dos princípios que atualmente norteiam as discussões sobre a alocação de responsabilidades entre os países:

1. Nível de emissões atuais: elege as emissões recentes como ponto de referência para todos os países definirem suas metas de redução;

2. Emissões acumuladas: considera como ponto de partida as emissões dos países, incluindo aquelas realizadas no passado;

3. População: iguala as emissões per capita em uma determinada data;

4. PIB per capita: reconhece como referência a capacidade dos países de pagar pela mudança do clima. Em Kyoto, metas quantificadas só foram aplicadas para as nações mais ricas do mundo;

5. Emissões por unidade de PIB: reconhece como ponto de partida a poluição inerente à elevação do nível de produção;

6. Redução potencial: adota como benchmark diferentes possibilidades de redução de emissões, considerando fatores tais como a estrutura econômica e o mix de combustíveis;

7. Custos e benefícios da redução: reflete as diferentes capacidades nacionais para reduzir custos e potencializar os benefícios da redução;

8. Com base nos agrupamentos nacionais existentes: elege como ponto de referência as responsabilidades por grupos de países. Por exemplo, emissões dos países membros da OCDE ou por não membros da OCDE.

A discussão sobre o mérito das abordagens que podem ser adotados para reduzir as emissões, incluindo cap and trade, acordos setorias e políticas nacionais, não pode se confundir com o problema da alocação de responsabilidades. A escolha de um mecanismo não afeta a alocação nem define quem pagará pelo abatimento. 
Observe-se que a depender do princípio aplicado, as alocações produzirão resultados bastante diferenciados entre os países. Os estudos desenvolvidos no âmbito da IEA (2008) mostraram que, em geral, para os países não OCDE, com exceção da China, alocações baseadas na equalização das emissões per capita são maiores que as emissões atuais e projetadas no cenário de referência. Ao contrário, se as emissões são alocadas com base no PIB ou nas emissões atuais ou recentes, a aplicação desse princípio resultaria em pequenas necessidades de reduções das emissões dos países OCDE ${ }^{44}$.

Pelo princípio das emissões per capita, os países africanos, latino americanos e a Índia poderiam emitir significativos volumes adicionais dos GEE, porém a China e os países do Oriente Médio teriam que reduzir, obrigatoriamente, suas emissões, da mesma forma que os Estados Unidos, União Européia, Japão e Rússia.

Considerando o princípio das emissões correntes, o ônus das reduções das emissões recairia sobre os países em desenvolvimento e os países desenvolvidos ganhariam o direito a emitir acima dos níveis atuais. Finalmente, pelo princípio da relação com o PIB corrente, as reduções deveriam ser lideradas pela China, Índia, Rússia e países do Oriente Médio, e os países mais desenvolvidos elevariam ainda mais o direito de emitir.

Aparentemente, nenhum critério isoladamente é suficiente para dar conta das enormes assimetrias atualmente existentes entre os países, sendo recomendável a adoção de uma combinação de vários princípios e abordagens.

A discussão sobre as abordagens

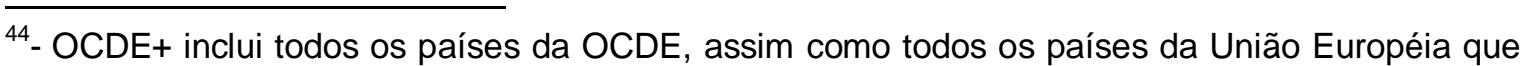
não são membros da OCDE. Outras Grandes Economias contém os maiores emissores fora da OCDE+ (baseado em suas emissões totais de $\mathrm{CO}_{2}$ relacionado a energia em 2006): China, Rússia, Índia, Iran, Arábia Saudita, Indonésia, Brasil e África do Sul. Para propósitos de modelagem, foi incluído todo o Oriente Médio e excluída a África do Sul. No cenário 450 é assumido que Outras Grandes Economias participa no mecanismo Limitar-e-Negociar para a geração de energia e indústria para 2020 e adiante (WEO, 2008). 
A discussão internacional sobre as abordagens a serem adotados pós-2012 se concentra basicamente no cap and trade, acordos setorias e políticas nacionais ${ }^{45}$. Teoricamente, considera-se que a adoção de um sistema internacional de emissões com limite pré-estabelecido das emissões por país, com o comércio de emissões entre eles (cap and trade), oferece, potencialmente, a solução de menor custo em termos econômicos.

Entretanto, essa opção encontra sérias dificuldades políticas e práticas para determinar uma equitativa alocação inicial das quotas de emissões. Além disso, não conta com o apoio dos países em desenvolvimento e pobres, que consideram que a adoção desse sistema limitaria suas possibilidades de crescimento econômico.

Por isso, algumas análises consideram que é realista imaginar que as nações adotem uma ou mais de uma dessas abordagens para atender da melhor forma possível as suas necessidades, interesses e capacidades. Ainda que argumentos contra esse posicionamento possam ser oferecidos, o debate atual mostra que 0 mais provável de ocorrer no regime futuro é a combinação de diversas abordagens, cujo mix deverá ser formatado de modo a atender, simultaneamente, as circunstâncias e necessidades específicas dos países e as necessárias interconecxões em nível internacional para atingir o máximo de eficiência econômica.

A IEA (2008) apresentou uma proposta de mix, utilizando essas três abordagens. Essa proposta define limitações ou metas obrigatórias apenas para os países OCDE, nos setores de geração de energia e indústria. Admite nos demais setores (transportes e construção) acordos setoriais internacionais e políticas e medidas nacionais. Para outras grandes economias, a exemplo da China, Índia e Brasil, propõe políticas e medidas nacionais para o setor energético, para o setor industrial e transportes. Sugere acordos setoriais e políticas e medidas nacionais para o segmento da construção. Para outros países sugere apenas a aplicação de políticas e medidas nacionais. Apesar de genérica, essa proposta,

\footnotetext{
45- É importante observar que várias outras abordagens têm sido propostas na literatura internacional, algumas das quais deverão discutidas na COP15, em Copenhagen.
} 
aparentemente, resume as grandes linhas de discussões da agenda de Copenhague.

Em síntese, considerando as análises e informações atualmente disponíveis observa-se que nos próximos meses um grande esforço internacional terá que ser realizado para que até a realização da 15스 COP em Copenhagen, um acordo mundial para combater o aquecimento global seja conquistado, avançando para além dos esforços do Protocolo de Kyoto na luta contra as mudanças climáticas. As características e perfil desse acordo dependerão do entendimento que os países têm sobre a urgência do problema e sobre a necessidade de que ações rápidas e fortes sejam implementadas.

Para tanto, além da definição de uma meta de estabilização das concentrações atmosféricas dos GEE e dos princípios para a alocação de responsabilidades nacionais será ainda necessário que seja alcançado um amplo consenso sobre as abordagens que serão adotadas para determinar como cada país implementará suas ações para reduzir as emissões dos GEE. Mais: será necessário assegurar ao lado do estabelecimento de metas de reduções das emissões de longo prazo, a transferência tecnológica, visando garantir a transição para uma economia baseada em baixas emissões de carbono.

Naturalmente, tratando-se de um Acordo multilateral, os interesses e necessidades nacionais, que são, com freqüência, conflitantes, tornarão esse caminho mais difícil e, em alguns casos, muitas barreiras não poderão ser removidas. Geralmente, os países mais desenvolvidos, sobretudo, os países europeus apontam para a necessidade de compromissos e ações mais fortes e rápidas para combater o aquecimento global, enquanto os países em desenvolvimento e os países mais pobres advogam que essas ações, embora necessárias, não podem frear o crescimento das suas respectivas economias. Argumentam que qualquer compromisso para limitar emissões resultaria em forte desaceleração no crescimento econômico. 
Sobre essa questão, vale citar Goldemberg (2008), contrapondo-se a esse argumento:

Isso só é verdade se eles (os países em desenvolvimento) adotarem a mesma trajetória de desenvolvimento poluente e predatória que os atuais países industrializados adotaram no passado, quando se desenvolveram. A solução é adotar uma trajetória que incorpore ao processo de desenvolvimento as tecnologias mais modernas e menos poluentes, que não existiam no passado, mas existem hoje. (GOLDEMBERG, 2008) ${ }^{46}$

Vale ressaltar, finalmente, que com a publicação do Relatório Stern sobre a economia das mudanças climáticas ficou claro que o custo da inação é muito superior ao custo associado aos esforços necessários para a implementação de um amplo e agressivo programa de mitigação das emissões dos GEE.

No entanto, o Relatório Stern recebeu críticas em relação à taxa de desconto adotada, considerada como muito baixa por muitos economistas. Por exemplo, William Nordhaus ${ }^{47}$ (apud BROOME, 2008), usando uma taxa de desconto de 6\% concluiu que a necessidade de ação não é tão urgente. A taxa de desconto aplicada, de fato, faz uma enorme diferença nos resultados, em termos do valor futuro dos bens no presente.

Com efeito, a taxa de desconto de 1,4\% usada por Stern atribui um valor relativamente alto ao bem-estar das gerações futuras, enquanto que a taxa usada por W. Nordhaus reduz bastante esse valor. Por essa razão,

o efeito (do uso de diferentes taxas de desconto) é que Stern atribui um valor presente de US\$247 bilhões para, digamos, US\$1 trilhão daqui a um século e Nordhaus avalia os mesmos bens em 2108 como equivalentes a apenas US $\$ 2,5$ bilhões hoje. (BROOME, 2008, p.91) ${ }^{48}$

A conseqüência dessas duas conclusões recai diretamente sobre as decisões relacionadas "ao quanto" a geração atual deve sacrificar de consumo hoje para garantir às futuras gerações benefícios de longo prazo. É esse julgamento, ético

\footnotetext{
46- Artigo publicado no jornal O Estado de São Paulo, em 24/05/2008.

${ }^{47}$ - No artigo Broome não cita o nome do estudo nem faz referência à data da publicação de $\mathrm{W}$. Nordhaus.

48. Artigo publicado na Scientific American Brasil, ano 6, $n^{\circ}$ 74. p. 88-93, 2008.
} 
por natureza, que informa e justifica a proposição do Relatório Stern ${ }^{49}$, que recomenda um gasto maior hoje para mitigar as mudanças climáticas no futuro.

Apesar da relevância dessa discussão, o sucesso de um acordo como este vai depender muito mais da política e do posicionamento ético que os governos adotem do que de uma eventual convergência entre os economistas sobre a taxa de desconto a ser adotada.

Aparentemente, o fundamental é a formulação de propostas que combinem diversas abordagens, incluindo ações tanto nos países desenvolvidos, em particular os EUA, quanto nos países em desenvolvimento, sobretudo, na China, Índia, Brasil. Essa combinação de abordagens deve refletir as circunstâncias a as realidades políticas dos diferentes países e regiões no mundo. Dentre essas abordagens destacam-se o cap and trade, os acordos setorias e as políticas de medidas nacionais.

49- Em recente entrevista coletiva Stern anunciou que os cenários projetados no relatório de 2006 estão defasados e que os prejuízos da inação podem chegar aos $30 \%$ do PIB mundial e não aos $20 \%$ como estimados no referido Relatório. 


\section{Capítulo 3 Protocolo de Kyoto: MDL e Mercado de Carbono}

O presente capítulo explora o Mecanismo de Desenvolvimento Limpo (MDL), com ênfase nos procedimentos e condicionantes para a determinação da linha de base e da adicionalidade de projetos candidatos ao MDL. Apresenta as estatísticas das metodologias aprovadas por escopo de projetos, analisa os resultados em nível internacional e fornece uma visão panorâmica sobre o mercado internacional de carbono e o MDL no Brasil, em relação aos aspectos regulatórios, instâncias constituídas, projetos aprovados e escopo desses projetos e as linhas gerais do Plano Nacional de Mudanças Climáticas (PNMC) coordenado pelo Ministério do Meio Ambiente (MMA) ${ }^{50}$.

\subsection{Breve histórico}

O reconhecimento científico e político de que as mudanças climáticas estão ocorrendo em conseqüência do acelerado processo de acumulação na atmosfera dos gases de efeito estufa provocado pelas atividades humanas apontou para a necessidade de um acordo internacional que refletisse o esforço comum das nações para mitigar as emissões desses gases.

Em 1990, a Assembléia Geral das Nações Unidas por meio do Comitê Intergovernamental de Negociação preparou a redação da Convenção-Quadro das Nações Unidas Sobre Mudança do Clima (CQNUMC), que foi adotada em 9 de maio de 1992 na sede das Nações Unidas, em Nova York (MCT) ${ }^{51}$.

A primeira iniciativa que resultou na adoção de um compromisso amplo entre as nações ocorreu durante a Conferência das Nações Unidas para o Meio Ambiente

\footnotetext{
50. O PNMC foi publicado pela primeira vez em setembro de 2008 e em dezembro de 2008 foi republicado, sendo lançado na COP14 realizada em Poznan, na Polônia.

51 - MCT/MRE - Tradução da Convenção disponível em http://www.mct.gov.br/clima/convencao/ guia.htm
} 
e Desenvolvimento, em junho de 1992, no Rio de Janeiro. A partir da realização da Conferência, a Convenção esteve aberta a assinaturas, e entre 1992 e junho de 1993 havia recebido 166 assinaturas.

A Convenção entrou em vigor em 21 de março de 1994 e até julho de 2007 havia sido ratificada por 192 países (MCT, 2007). Os países signatários da Convenção se comprometeram com o objetivo final da Convenção que

\begin{abstract}
é o de alcançar, em conformidade com as disposições pertinentes desta Convenção, a estabilização das concentrações de gases de efeito estufa na atmosfera num nível que impeça uma interferência antrópica perigosa no sistema climático. Esse nível deverá ser alcançado num prazo suficiente que permita aos ecossistemas adaptarem-se naturalmente à mudança do clima, que assegure que a produção de alimentos não seja ameaçada e que permita ao desenvolvimento econômico prosseguir de maneira sustentável (CQNUMC, 1992, art.2, p.6 $)^{52}$.
\end{abstract}

Reconhecendo a mudança do clima como uma preocupação comum da Humanidade os países signatários da Convenção firmaram o compromisso de colaborar para a elaboração de uma estratégia global, visando proteger o sistema climático para gerações presentes e futuras,

com base na equidade e em conformidade com suas responsabilidades comuns mas diferenciadas e respectivas capacidades, levando em conta também (....) as necessidades específicas e circunstâncias especiais das Partes países em desenvolvimento, em especial aqueles particularmente mais vulneráveis aos efeitos negativos da mudança do clima (Ibid., art. 3, p. 6 e 7).

A Convenção assumiu a responsabilidade de criar condições e desenvolver instrumentos e mecanismos que possibilitassem alcançar a estabilização dos gases de efeito estufa na atmosfera em níveis que não interferissem perigosamente no sistema climático e que, ao mesmo tempo, garantissem o desenvolvimento sustentável.

\footnotetext{
52- Texto editado e traduzido pelo Ministério da Ciência e Tecnologia (MCT) do Brasil. http://www.mct.gov.br/upd_blob/0005/5390.pdf
} 
Com base nesse Acordo, que entrou em vigor em 1994, os países industrializados ${ }^{53}$, são os principais responsáveis pelo corte das emissões dos gases de efeito estufa. A Convenção, considerando as responsabilidades históricas de emissões estabeleceu como princípio o compartilhamento do ônus na luta contra $\mathrm{o}$ aquecimento da Terra, atribuindo compromissos $e$ responsabilidades exclusivas em relação à mitigação das mudanças climáticas aos países industrializados relacionados no Anexo I (Ibid., art. 4, 2a, p. 9).

Em 1995 foi realizada na Alemanha, a Primeira Conferência das Partes (COP1), que aprovou o Mandato de Berlim (Decisão 1/CP.1), através do qual foram definidos os limites para as emissões dos gases causadores do efeito estufa e o calendário para o cumprimento das obrigações assumidas pelos países. Nesse protocolo, foi constituído o Activities Implemented Jointly (AJI) ${ }^{54}$, possibilitando aos países do Anexo I implementarem medidas conjuntas para a redução das emissões.

Na $2^{a}$ Conferência das Partes (COP2), ocorrida em julho de 1996, em Genebra foi apresentado o Segundo Relatório de Avaliação (SAR) do IPCC, cujas conclusões apontaram para a necessidade de ações fortes e urgentes nos plano mundial, nacional e regional, direcionadas para o estabelecimento de metas obrigatórias e significativas de redução global das emissões.

Apoiada nos resultados do Segundo Relatório (SAR), a $3^{\text {a }}$ Conferência das Partes (COP3), realizada em 1997 celebrou o Protocolo de Kyoto ${ }^{55}$, através do qual foram estabelecidas as metas, os prazos de redução ou limitação das emissões futuras dos gases de efeito estufa e as medidas necessárias ao cumprimento das metas, atribuindo ênfase às obrigações das nações desenvolvidas.

\footnotetext{
53- Denominados Países Anexo 1, no âmbito da Convenção-Quadro das Nações Unidas para a Mudança do Clima.

${ }^{54}$ - Decisão 5/CP.1

${ }^{55}$-Texto completo do Protocolo de Kyoto encontra-se no endereço: http://www.mct.gov.br/index.php/content/view/28739.html
} 
Os países que assinaram o Protocolo concordaram que as emissões dos países do Anexo 1 deveriam ser reduzidas, em média, 5,2\% abaixo dos níveis registrados em 1990. Tal redução deveria ocorrer entre 2008-2012, período conhecido como o primeiro período de compromisso.

As metas quantificadas de redução encontram-se especificadas para cada país no Anexo B do Protocolo, em porcentagem em relação a 1990, ano base. O Protocolo de Kyoto entrou em vigor em fevereiro de 2005, quando foi ratificado por 55 países signatários da Convenção cujas emissões agregadas representavam 55\% das emissões dos países listados no Anexo 1, em 1990.

\subsection{Mecanismos de Flexibilização: regras e procedimentos}

Além das metas quantificadas de redução das emissões, o Protocolo prevê três mecanismos de flexibilização a serem utilizados, de forma complementar, pelos os países listados no Anexo1 para o cumprimento das metas de redução das emissões. São eles: Implementação Conjunta, Comércio de Emissões e o Mecanismo de Desenvolvimento Limpo (MDL). Os dois primeiros mecanismos só podem ser utilizados e executados entre os países do Anexo I. Os países que não fazem parte do Anexo I, como é o caso do Brasil participam apenas do MDL.

\subsubsection{O que é e como funciona o $M D L^{56}$ ?}

O MDL tem como objetivo contribuir para a redução das emissões dos gases de efeito estufa em países em desenvolvimento e pobres, a partir da utilização de sumidouros $^{57}$, dos investimentos em tecnologias limpas, da busca de maior

\footnotetext{
56. Informações detalhadas sobre o MDL encontram - se no endereço: www.mct.gov.br/ index.php/content/view/4007.html

57 - Sumidouro - quaisquer processos, atividades ou mecanismos, incluindo a biomassa e, em especial, florestas e oceanos, que têm a propriedade de remover um gás de efeito estufa,
} 
eficiência energética e do uso de fontes alternativas de energia. Esse mecanismo destaca-se por considerar a questão das emissões do ponto de vista da responsabilidade histórica ou acumulada de cada país, por assistir as partes não incluídas no Anexo 1, no sentido de levá-las a alcançar um desenvolvimento sustentável e por prever a aplicação de penalidades aos países relacionados no Anexo 1 que ultrapassarem as cotas anuais de emissões, previamente estabelecidas.

Regulamentado pelo artigo 12 do Protocolo de Kyoto, o MDL permite que os investimentos realizados pelos países listados no Anexo 1 recebam Certificados de Emissões Reduzidas (CER) pelo montante de emissões reduzidas que consigam atingir com a implementação de atividades de projetos, supostamente mitigadores das emissões dos gases de efeito estufa. Por meio do MDL, projetos desenvolvidos que resultem em reduções de emissões valerão créditos, que poderão ser transacionados no mercado internacional de carbono.

Os países em desenvolvimento que não têm obrigações de redução de suas emissões podem hospedar atividades de projetos que reduzam as emissões dos gases de efeito estufa e contribuam para o desenvolvimento sustentável. Por sua vez, os países desenvolvidos, que têm obrigações de redução das suas emissões, poderão utilizar os Certificados de Emissões Reduzidas (CER) resultantes das atividades de projetos, para cumprir, parcialmente, seus compromissos quantificados de redução das emissões.

Uma componente chave do MDL é o requerimento da adicionalidade dos projetos, ou seja, emissões reduzidas com projetos de MDL somente serão reconhecidas se o proponente do projeto demonstrar que, com a implementação das suas atividades, as emissões dos GEE serão menores do que aquelas que ocorreriam na ausência dele. Em face às óbvias dificuldades para determinar a adicionalidade, na medida em que a existência do projeto impede a demonstração do cenário na ausência dele, o Comitê Executivo do MDL aprovou 
um procedimento, denominado ferramenta para medir a adicionalidade ${ }^{58}$, cuja aplicação permitiria reconhecer se o projeto é ou não adicional.

De acordo com a última versão da ferramenta para demonstrar e avaliar a adicionalidade de um projeto candidato ao MDL trata-se, em primeiro lugar, de identificar se existe(m) ou não alternativa(s) ao projeto de MDL consistente(s) com as leis e regulamentações do país hospedeiro do projeto. Se o projeto é a única alternativa que atende a essa condição então ele não é adicional, na medida em que a implementação dele não dependeria das receitas oriundas dos créditos de carbono.

No entanto, se existe pelo menos mais uma alternativa que atenda à primeira condição, então o projeto atendeu ao primeiro critério para demonstrar a adicionalidade e deve prosseguir com uma análise de investimento para verificar se a atividade do projeto não é a mais economicamente ou financeiramente atrativa, ou se o projeto é economicamente ou financeiramente viável, sem as receitas das vendas dos certificados de emissões reduzidas (CER).

Se o projeto é mais atrativo, na comparação com uma alternativa, ou é viável, considerando o custo de oportunidade de capital da empresa/setor ou país, então ele não é adicional. Nesse caso, para continuar, o proponente deverá proceder a uma análise de barreiras. Se não existem barreiras ao projeto então ele não é adicional.

Se a análise de investimento ou a análise de barreiras identifica que o projeto não é o mais atrativo entre as alternativas disponíveis ou não é viável ou enfrenta barreiras então o projeto atendeu ao segundo critério para demonstrar a adicionalidade e o processo deve continuar com o desenvolvimento da análise da prática comum.

58. Tool for the demonstration and assessment of additionality, em inglês, cuja primeira versão foi aprovada em outubro de 2004, na $16^{a}$ reunião do Comitê Executivo (CE) do MDL. A $5^{\text {a }}$ versão, atualmente em vigor, foi aprovada em maio de 2008 durante $39^{a}$ reunião do CE. 
Se existem atividades similares desenvolvidas na área do projeto, então ele não é adicional. Se não existem atividades similares, ou se atividades similares existentes possuem características distintas às do projeto que podem ser razoavelmente descritas, então o projeto é adicional.

Os projetos devem contar com a participação voluntária dos países envolvidos, e deles poderão participar com projetos e/ou na aquisição dos certificados de emissões reduzidas (CER), entidades privadas e/ou públicas, sujeitas a qualquer orientação que possa ser dada pelo Conselho Executivo (CE) do MDL. As CER obtidas entre o ano de 2000 e o início do primeiro ano de compromisso, em 2008, poderão ser utilizadas para ajudar no cumprimento das metas relativas ao primeiro período de compromisso.

Basicamente duas grandes categorias de projetos podem ser desenvolvidas no âmbito do MDL:

a) projetos que reduzem as emissões;

b) projetos que resgatam emissões na forma de sumidouros e de estocagem dos GEE retirados da atmosfera.

$\mathrm{Na}$ primeira categoria enquadram-se os projetos de aumento da eficiência energética, projetos que utilizam fontes renováveis de energia, que adotam tecnologias mais eficientes de queima de combustíveis fósseis no setor energético, indústrias de transformação e construção, que desenvolvem sistemas mais avançados para o setor de transportes e para o setor produtivo em geral. As atividades de projetos relacionadas ao uso da terra, mudança do uso da terra e florestas pertencem à segunda categoria. 


\subsubsection{Conceito e premissas metodológicas da linha de base para sistemas elétricos}

Como anteriormente mencionado, um requerimento básico para os projetos candidatos ao MDL é demonstrar que eles são adicionais, ou seja, suas atividades efetivamente reduzem as emissões dos GEE e os volumes dessas reduções podem ser quantificados, considerando um cenário de referência ou uma linha de base.

Define-se como linha de base de uma atividade de projeto no âmbito do MDL como

O cenário que representa, de forma razoável, as emissões antrópicas de gases de efeito estufa por fontes que ocorreriam na ausência da atividade de projeto proposta. A linha de base deve cobrir as emissões de todos os gases, setores e categorias de fontes listados no Anexo A que ocorram dentro do limite do projeto (UNFCCC, 2001, parágrafo 44, p.18).

O nível de complexidade para a determinação da linha de base de um projeto candidato ao MDL varia em função de algumas de suas características, da sua abrangência espacial e temporal, do grau de dificuldade para a determinação das suas fronteiras, da possibilidade de vazamentos ${ }^{59}$, do desempenho dos equipamentos, do grau de confiabilidade dos dados utilizados e dos cenários projetados, da capacidade real para medir a adicionalidade do projeto, do nível de agregação utilizado, das categorias e tipos de projetos que representa, entre outras.

De um modo geral, se o projeto mitigador dos GEE substituirá e/ou modificará um empreendimento que já existe, e se encontra em funcionamento e suas atividades são fisicamente bem delimitadas, com histórico de emissões disponíveis e confiáveis, a determinação da linha de base apresenta pequeno grau de dificuldade. Para outros tipos de projetos, ou quando se trata de um

\footnotetext{
59. A definição de vazamento foi estabelecida como a variação líquida das emissões de gases de efeito estufa que ocorre fora dos limites do projeto e que é mensurada e atribuída à atividade do projeto MDL (OLIVEIRA; RIBEIRO, 2002).
} 
projeto que substituirá um empreendimento apenas planejado, a definição da linha de base não é uma tarefa simples, exigindo cuidados especiais para a sua determinação.

De acordo com Goldemberg (1998a), linhas de base definidas a partir de previsões sobre o comportamento futuro de variáveis macroeconômicas, crescimento da população, mudanças de hábitos e/ou variações nos padrões comportamentais de grupos sociais específicos ou da população de um modo geral, também são possíveis, porém apresentam dificuldades de serem estabelecidas de forma confiável. As linhas de base específicas para atividades de projetos são vistas como mais realistas se elas incorporarem o progresso tecnológico e o estado da arte das atividades que seriam feitas na ausência do projeto.

$\mathrm{Na}$ medida em que a definição de uma linha de base requer que alguns pressupostos sejam assumidos ela não pode ser empiricamente provada. Por isso, torna-se essencial para a aceitação de uma linha de base, que as partes envolvidas no projeto, bem como as instituições nacionais e internacionais competentes e com atribuições para julgar os projetos elegíveis como MDL confiem na metodologia utilizada (YAMIN, 1998).

Para Michaelowa (1998), parâmetros relacionados com a escala do projeto, tempo de vida útil da linha de base e dos equipamentos e viabilidade econômica dos projetos devem ser considerados no cenário da linha de base. Como a qualidade da linha de base é um parâmetro crítico sugere a utilização de abordagens simplificadas porque, além de reduzir erros, são mais confiáveis.

Três outras observações relacionadas à construção das linhas de base devem ser destacadas: a primeira se refere à necessidade de contabilização de emissões de GEE geradas na produção de insumos utilizados nas atividades do projeto, tratando-se de linha de base específica. A segunda relaciona-se com as emissões provocadas pelo chamado efeito preço, na medida em que poderia estimular o uso de combustíveis fósseis mais intensivos em carbono, incentivando a elevação das emissões. Finalmente deve-se considerar o efeito 
dos subsídios sobre a produção e uso dos combustíveis fósseis, para identificar o real nível de produção e uso desses combustíveis na ausência dos subsídios. (GOLDEMBERG, 1998a).

Outro aspecto freqüentemente apontado na literatura refere-se à possibilidade de construção de uma linha de base para determinadas classes de projetos, prevendo-se mudanças do cenário de referência ao longo do tempo. É muito importante que a metodologia incorpore a dinâmica da realidade para dar conta de prováveis mudanças tecnológicas e/ou de contexto político, institucional e regulatório dos países hospedeiros das atividades do projeto (Panayotou, 1998).

Conforme Hamwey e Szekely (1998), tratando-se da construção de uma linha de base em nível de país, apenas o grupo de instalações com maior peso e ordenadas por eficiência deveriam ser consideradas para evitar o que ele chamou de incentivo perverso, ou seja, a restrição impede que um país eleve o nível de sua linha de base nacional pelo estabelecimento de novas instalações altamente emissoras em paralelo com instalações pouco emissoras estabelecidas através de atividades de projetos de MDL.

Segundo esses autores, a linha de base para atividades de projetos elegíveis de MDL no setor de energia elétrica pode ser definida a partir das informações disponíveis sobre o comportamento das emissões dos GEE e da geração de energia elétrica existente no país, reduzindo ou quase eliminando as incertezas. A linha de base deveria ser calculada a partir das informações do país sobre energia gerada e o nível associado das emissões do setor elétrico. Por requerer apenas essas duas informações, que podem ser determinadas com precisão, os cálculos da linha de base poderiam ser facilmente desenvolvidos e os resultados prontamente estabelecidos.

Para os autores acima mencionados, essa estrutura ofereceria uma aproximação confiável e transparente para a determinação da linha de base, aplicando-se universalmente a qualquer projeto. Para garantir que o progresso técnico seja incorporado na linha de base, somente as instalações de mais alta eficiência deveriam ser incluídas nos cálculos. Se a definição da linha de base leva em 
conta essa condição então, uma vez calculada, manter-se-ia fixada para toda a vida útil do projeto.

$\mathrm{Na}$ medida em que a linha de base se modifica com o tempo, refletindo as mudanças na infraestrutura do setor considerado de cada país, projetos que serão implementados no futuro deveriam também utilizar as linhas de base observáveis no futuro. É importante notar que, de acordo com essa visão, a linha de base do projeto pela qual as emissões seriam medidas durante a vida útil do projeto deveria ser aquela fixada como tal na data de sua certificação, sendo monitorada ao longo do período de obtenção dos créditos de carbono. Desta maneira, as condições expressas pelas linhas de base estariam garantidas pelos países hospedeiros e países patrocinadores, durante todo o período de duração do projeto (HAMWEY; SZEKELY, 1998).

No entanto, tratando-se de parques geradores predominantes hídricos, o comportamento estocástico da hidrologia não permite que seja determinado, mesmo considerando o curtíssimo prazo, como será composto o mix da oferta de energia elétrica para atender um determinado volume de energia elétrica requerida pelo mercado. Nessas condições, a quantificação do volume de emissões reduzidas ou deslocadas com a entrada do projeto supostamente mitigados dos GEE é muito complexa e depende do nível de acesso a um grande número de informações sobre o parque gerador que está sendo considerado, da política operativa do mesmo, das expectativas em relação ao comportamento da demanda agregada, da (in) estabilidade do marco regulatório, da capacidade e disposição de investir, entre outros aspectos de natureza micro e macroeconômicas.

Além disso, diferente de parque predominante térmico, cuja tendência é reduzir as emissões dos GEE, com a entrada de novas e mais modernas tecnologias de queima dos combustíveis fósseis, um parque predominantemente hídrico, para manter-se nessa condição dependerá: primeiro, de que as novas plantas adicionadas para a sua expansão continuem sendo realizadas com aproveitamentos hídricos, segundo, que a energia gerada por esses empreendimentos seja mais barata e terceiro, que o despacho das usinas seja 
realizado rigorosamente por ordem de mérito, se efetivamente o despacho das usinas hidrelétricas for mais barato. Essas questões e outras relacionadas ao SIN serão retomadas nos capítulos 5 e 6 do presente trabalho.

As metodologias desenvolvidas para a determinação de linhas de base em sistemas elétricos hidrotérmicos buscam responder a seguinte pergunta: o que a entrada do projeto no sistema deslocará? Basicamente, três respostas podem ser oferecidas:

1) O projeto desloca parte da eletricidade produzida pelas usinas existentes no parque gerador;

2) O projeto desloca ou posterga a construção de novas de usinas, ou seja, o projeto é capaz de influenciar se ou quando as novas plantas serão construídas;

3) O projeto desloca uma combinação das duas alternativas anteriores.

Admite-se, em geral, que pequenos projetos não deslocarão grandes empreendimentos planejados, ou seja, eles não serão capazes de influenciar as decisões de investimentos relacionadas com novas plantas, dado que a quantidade de energia gerada por eles é muito pequena em relação ao total da geração proveniente da capacidade instalada no parque gerador. Nessas condições, tratando-se de pequenos projetos, pressupõe-se que eles deslocarão apenas parte da energia gerada pelas usinas existentes.

Diferentes abordagens e níveis de padronização poderão ser utilizados para a definição da linha de base. Tais níveis de padronização vão desde valores de emissões fixados em termos absolutos, por exemplo, $\mathrm{XGgCO}_{2} / \mathrm{ano}$, ou em termos de taxas, $\mathrm{YGgCO}_{2} / \mathrm{GWh}$, passando pelo desenvolvimento de metodologias padronizadas para um determinado setor ou tipo de projeto, até a padronização de apenas alguns parâmetros, como o nível de agregação espacial dos dados, o tempo de vida útil da linha de base, fronteiras, expressão das unidades, etc. Em geral a escolha do nível de padronização da linha de base, dependerá das características e, sobretudo, tratando-se de projeto implementado no setor elétrico, da sua condição operacional, ou seja, se é ou não conectado à rede. 
Seja qual for o nível de padronização adotado, uma metodologia para definição da linha de base para o setor elétrico precisa definir se o projeto é ou não interligado, determinar as fronteiras, estabelecer a vida útil da linha de base, identificar as opções que serão consideradas em relação ao nível de restrição da linha de base (se a padronização é por algum tipo de combustível, se considera apenas os combustíveis fósseis ou se leva em conta todas as fontes e, finalmente, se a validação da linha de base é ex-ante ou ex-post). Quando o proponente faz a opção ex-ante, a linha de base definida no registro do projeto perante Comitê Executivo do MDL deverá permanecer válida durante todo o período de crédito escolhido, se a escolha for por 10 anos. Se a opção for expost, a validação da linha de base será atualizada e os certificados de emissões reduzidas emitidos após essa verificação.

Para projetos conectados ao SIN, como a CIMGC já adotou o método $c$ da análise dos dados do despacho, o fator de emissão considerado pelos proponentes dos projetos será monitorado, ao longo de todo o período de obtenção de crédito, desaparecendo, portanto, a opção ex-ante para a validação da linha de base.

No caso de projetos conectados à rede, as opções de linhas de base devem levar em conta, sempre que possível, a composição real do mix da geração de energia que provavelmente será deslocada, as tecnologias associadas aos empreendimentos que comporão as novas adições de capacidade instalada e as perspectivas de uso de tecnologias mais eficientes ou nível esperado de diversificação da plataforma energética do sistema elétrico considerado.

Atualmente grande parte dessas questões já foi superada com a aprovação pelo Comitê Executivo do MDL de 157 metodologias ${ }^{60}$ para estimar a linha de base, envolvendo 1515 projetos registrados. Desse total 92 metodologias aprovadas são para projetos de grande escala, 46 para projetos de pequena escala e 19

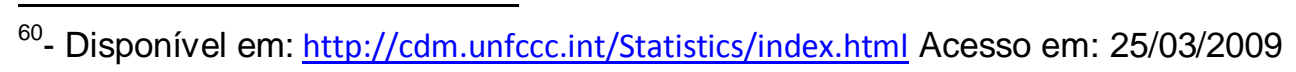


metodologias consolidadas. Ressalte-se que uma metodologia pode estar associada a mais de um escopo de projeto.

As metodologias para projetos de energia (renovável e não renovável) representam $27 \%$ do total, seguida da indústria manufatureira, com $15 \%$, florestamento e reflorestamento, com 10\%, da indústria química e manejo do lixo, com $9,5 \%$ e $9 \%$, respectivamente. Juntas as metodologias associadas aos projetos com os escopos acima mencionados perfazem $70,5 \%$ do total das metodologias aprovadas.

Ressalta-se que, independentemente do escopo do projeto, se o projeto for conectado a sistemas elétricos, os proponentes terão que calcular previamente o fator de emissão do sistema ao qual será conectado ou está conectado, que é a linha de base do projeto.

Como já mencionado em parte anterior do presente trabalho, atualmente esse fator é calculado com base no Tool to calculate the emissions factor, for an electricity system, cuja reflexão crítica em torno da pertinência da sua aplicabilidade para determinar o fator de emissão de projetos de MDL conectados ao SIN, motivou a proposta metodológica objeto dessa pesquisa.

\subsection{Protocolo de Kyoto e MDL: Resultados e Mercado de Carbono}

De acordo com as estatísticas divulgadas pela UNFCCC em março de 2009, estima-se que os 1.515 projetos registrados gerem 1,5 bilhões de Certificados de Emissões Reduzidas (CER), com média anual de 276,4 milhões de CER emitidas. Os mais de 4.200 projetos que compõem o pipeline do MDL deverão gerar até o final de 2012, algo em torno de 2,9 bilhões de CER, com volume anual superior a 700 milhões CER.

A expectativa de distribuição média anual desses certificados por país, considerando os projetos registrados, mostra que a China absorverá, em termos 
anuais, quase $57 \%$ do total, seguida da Índia, com $12 \%$, o Brasil com pouco mais de $7 \%$ e a República da Coréia, com quase $5 \%$ do total. Vale ressaltar, que desses quatro países, apenas a China elevou sua participação na comparação com os números registrados no início de 2008. O Brasil perdeu dois pontos percentuais, entre outubro de 2008 e março de 2009. O Gráfico 9, mostra a distribuição anual estimada para um conjunto maior de países.

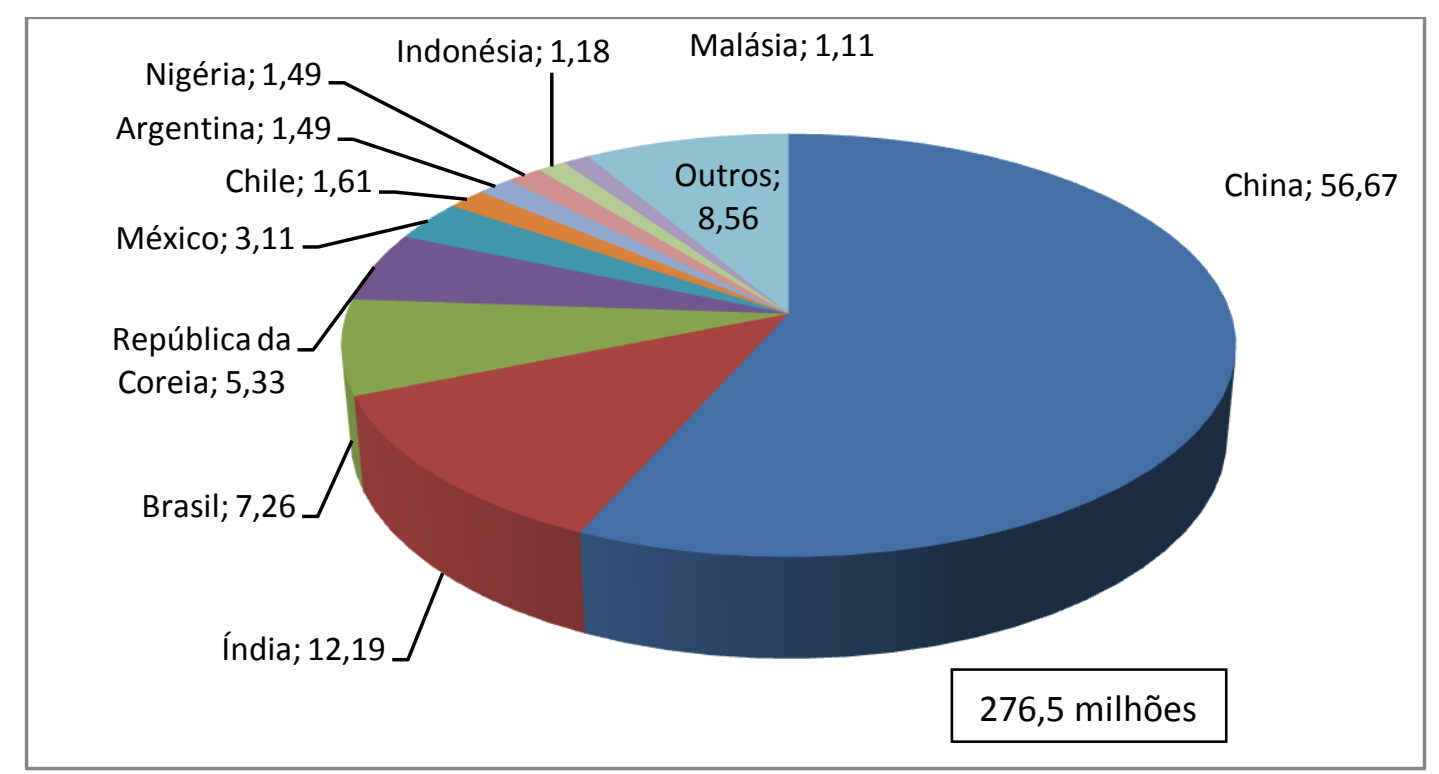

Gráfico 9 - Estimativa da distribuição de CER dos projetos registrados por País.

Fonte: Disponível em: htpp://cdm.unfccc.int(c), (tradução nossa). Acesso em 24/03/2009

Em março de 2009, um pouco mais de 270 milhões de CER foram emitidas. A China, a Índia, a Coréia e o Brasil, nessa ordem, são os maiores beneficiários, com a China liderando o ranking, seguida de longe pela Índia, Coréia e Brasil. Observe-se que, mais uma vez, na comparação com os dados de outubro de $2008^{61}$ a China eleva significativamente a sua participação, passando de $38 \%$ para quase $43,5 \%$. Todos os demais países, exceto o Vietnam, perdem participação. No Gráfico 10, encontram-se discriminados os percentuais dos seis países que mais receberam CER.

\footnotetext{
${ }^{61}$ - Em outubro de 2008 a seguinte distribuição foi observada: China, 37,5\%, Índia, 24\%, Coréia
} $17,5 \%$ e Brasil, $12,5 \%$. 


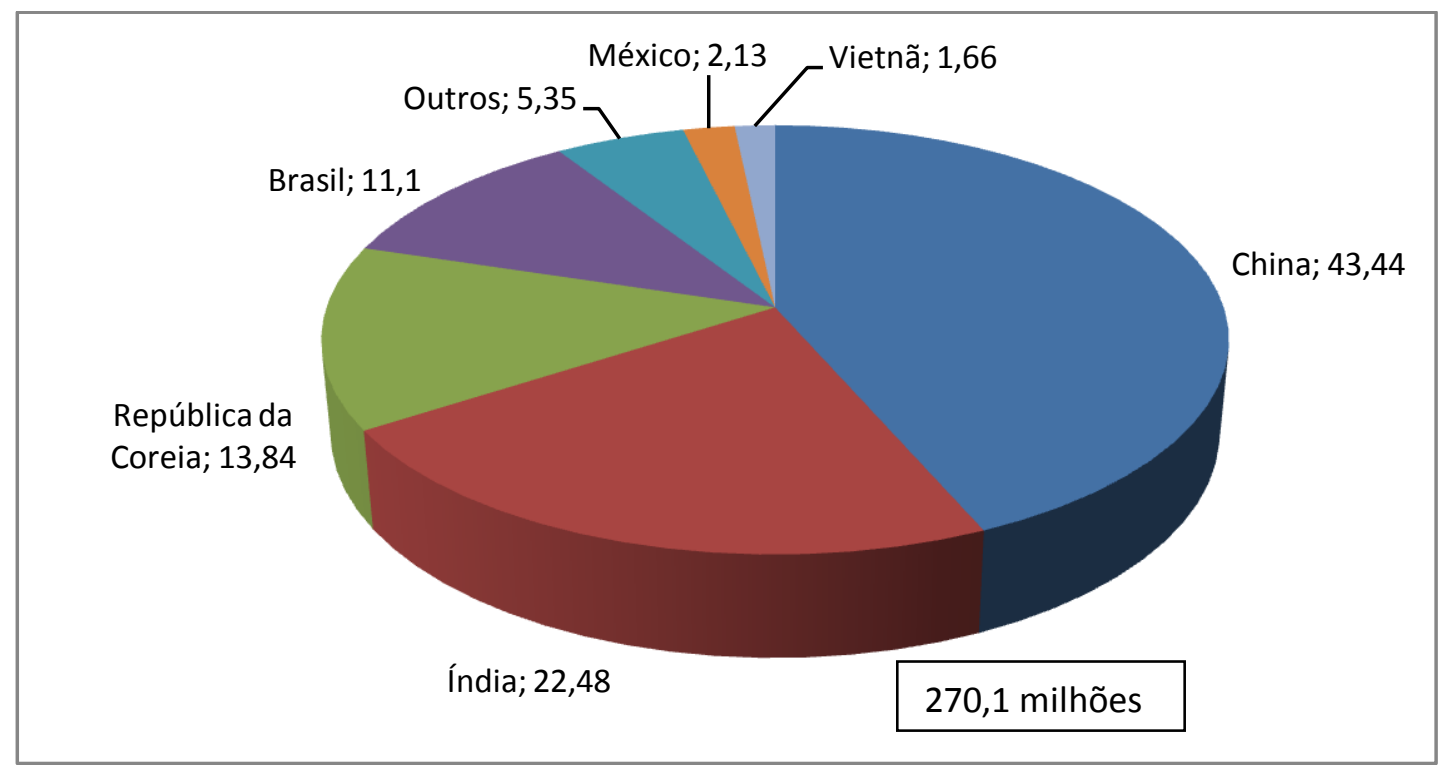

Gráfico 10 - CER distribuídas por País

Fonte: Disponível em: htpp://cdm.unfccc.int(c), (tradução nossa). Acesso em 24/03/2009

É importante ressaltar que a China tem aproveitado intensamente as oportunidades do MDL, sobretudo porque as atividades dos projetos MDL desenvolvidos naquele país apresentam grande adicionalidade em função do alto nível de fossilização da matriz energética chinesa.

A análise da distribuição dos projetos por escopo ${ }^{62}$ revela o peso numérico dos projetos registrados no desenvolvimento de atividades associadas à indústria de energia renováveis, com $68 \%$ do total, porém responsáveis por apenas $21 \%$ das reduções das emissões estimadas para 2012.

Em sentido contrário, os projetos de redução de óxido nitroso e HFC e da indústria de cimento, representando apenas $6,5 \%$ do número de projetos serão responsáveis por $54 \%$ das reduções estimadas em 2012. Os projetos de utilização e reutilização de metano e de gás de aterro representam $20 \%$ do número de projetos, com reduções de emissões da ordem de $20 \%$, em 2012 e os de emissões fugitivas participam com $8 \%$ do total.

\footnotetext{
62 - Análise realizada com base nas informações publicadas pelo IGES (International Review for
} Environmental Strategies), em junho de 2008. 
A Tabela 6 apresenta o detalhamento das informações. A distribuição por tamanho dos projetos mostra-se equilibrada, sendo que do total registrado, $54 \%$ são de larga escala e 46 de pequena escala.

Para alguns analistas, os resultados alcançados poderiam ter sido melhores e apontam como principais razões impeditivas a um melhor desempenho, os custos de registro, que para alguns tipos de projetos permanecem elevados, as dificuldades para os projetos demonstrarem a adicionalidade, de forma aceitável para o Comitê Executivo (CE) do MDL e o longo processo para a aprovação de novas metodologias. 
Tabela 6 - Distribuição dos projetos registrados no MDL por escopo, reduções CER emitidas e estimativas das CER para 2012

\begin{tabular}{|c|c|c|c|c|c|}
\hline \multirow[b]{2}{*}{ Tipo de Projeto } & \multicolumn{2}{|c|}{ Registro } & \multicolumn{3}{|c|}{ Emissão } \\
\hline & $\begin{array}{c}\text { Número } \\
\text { de } \\
\text { Projetos }\end{array}$ & $\begin{array}{c}\text { Redução das } \\
\text { Emissões em } \\
2012 \text { (PDD } \\
\text { estimativa) }\end{array}$ & $\begin{array}{l}\text { Número } \\
\text { Projetos }\end{array}$ & $\begin{array}{l}\text { Total de CER } \\
\text { Emitidas }\end{array}$ & $\begin{array}{l}\text { Estimativa de } \\
\text { CER em } 2012\end{array}$ \\
\hline Hidrelétrica & 208 & 78.649 .544 & 60 & 5.802 .326 & 63.352 .192 \\
\hline Biomassa & 203 & 70.726 .521 & 86 & 8.996 .961 & 53.322 .780 \\
\hline Biogás & 173 & 46.107 .425 & 44 & 3.657 .289 & 20.718 .887 \\
\hline Eólica & 144 & 78.732 .069 & 64 & 4.580 .278 & 37.369 .339 \\
\hline $\begin{array}{l}\text { Utilização/Reutilização } \\
\text { de Metano }\end{array}$ & 90 & 149.494 .445 & 23 & 4.047 .040 & 60.092 .188 \\
\hline $\begin{array}{l}\text { Utilização Gás/Calor de } \\
\text { Aterro }\end{array}$ & 76 & 103.219 .671 & 23 & 12.065 .817 & 105.972 .321 \\
\hline Eficiência Energética & 54 & 11.505 .104 & 17 & 669.321 & 9.397 .920 \\
\hline Mudança Combustível & 34 & 51.586 .300 & 13 & 1.261 .482 & 35.472 .523 \\
\hline Redução de $\mathrm{N}_{2} \mathrm{O}$ & 32 & 227.719 .179 & 6 & 32.579 .106 & 370.916 .618 \\
\hline Cimento & 22 & 21.931 .337 & 8 & 1.289 .603 & 12.591 .686 \\
\hline Redução de HFC & 17 & 459.410 .200 & 15 & 80.541 .321 & 455.084 .876 \\
\hline Metano Evitado & 14 & 5.309 .803 & 1 & 552.726 & 5.158 .718 \\
\hline $\begin{array}{l}\text { Outras Energias } \\
\text { Renováveis }\end{array}$ & 13 & 10.958 .044 & 3 & 293.671 & 4.111 .904 \\
\hline $\begin{array}{l}\text { Florestamento e } \\
\text { reflorestamento }\end{array}$ & 2 & 1.962 .752 & 1 & 59.020 & 469.826 \\
\hline Evapotranspiração & 1 & 340.223 & 0 & 0 & 340.223 \\
\hline Redução de PFC & 1 & 195.491 & 0 & 0 & 195.491 \\
\hline Total & 1084 & 1.317 .848 .109 & 364 & 156.395 .961 & 1.234 .567 .492 \\
\hline
\end{tabular}

A expectativa é que com a aprovação de novos procedimentos, como a criação do MDL programático, que flexibiliza vários aspectos dos procedimentos tradicionais relacionados com a apresentação de projetos individuais, esse quadro seja qualitativamente alterado, sobretudo com a entrada e registro de um volume significativo de projetos de eficientização pelo lado da demanda. 
Destaque-se que as informações disponíveis no site da UNFCCC mostram que em março de 2009 a distribuição de CER estimadas até 2012 é de 2,9 bilhões, $16 \%$ superior a esta estimada pelo IGES em 2006, de 2,5 bilhões.

Se por um lado esses resultados revelam a contribuição do MDL para que os países desenvolvidos cumpram suas metas quantificadas de emissões, por outro, a análise com foco na participação dos projetos no pipeline, por tipo de projeto mostra uma estimativa de distribuição de CER, em 2012, pouco favorável para as atividades de projetos que contribuem de forma mais efetiva para o desenvolvimento sustentável.

Com efeito, de acordo com as análises desenvolvidas por Ellis (2006) e Hinostroza, et al.(2007), 37\% da distribuição estimada para 2012, de 3 bilhões, contemplará projetos de redução de gases industriais (HFC, PCF e $\mathrm{N}_{2} \mathrm{O}$ ), cuja contribuição para o desenvolvimento sustentável é questionável.

As CER associadas a projetos que contribuem mais para o desenvolvimento sustentável, como aqueles que usam energias renováveis e/ou aqueles que promovem a eficiência energética e a troca de combustíveis fósseis não estarão bem representados.

Nesse sentido, são importantes as análises e dados apresentados por Figueres e Philips (2007) e Hinostroza et al. (2007), confirmando as dificuldades que enfrentam, no âmbito do MDL, os projetos de eficiência energética e propondo que novos procedimentos, a exemplo do MDL programático ( $\mathrm{pMDL}$ ) e dos Programas de Atividades (PoAs), sejam adotados para elevar a implementação de projetos de eficiência energética pelo lado da demanda.

Estima-se que do total das CER distribuídas em 2012, 7\% serão vinculadas a projetos de troca de combustíveis fósseis, $22 \%$ a projetos de energias renováveis e apenas $9 \%$ a projetos de eficiência energética. Os projetos de eficiência energética pelo lado da demanda representarão somente $1 \%$ do total. 
Apesar dessa distribuição desfavorável em relação ao escopo dos projetos sob a ótica do desenvolvimento sustentável, o mercado internacional de carbono tem crescido, demonstrando que ele pode oferecer uma importante contribuição para reduzir no futuro as emissões dos GEE em todo o mundo.

De acordo com o Capoor e Ambrosi $(2007)^{63}$, os mercados de carbono, regulados e não regulados, são partes fundamentais para responder às mudanças climáticas, sendo eles responsáveis por transações estimadas em US\$30 bilhões, envolvendo volumes de reduções das emissões da ordem de 1.637 $\mathrm{MtCO}_{2}$-eq, em 2006.

$\mathrm{Na}$ Tabela 7 são fornecidas as informações sobre os volumes e valores desses mercados em 2005 e 2006. A maior parte das transações de venda e re-venda foi do European Union Allowances (EU ETS), com 67\% dos valores transacionados, colocando-se em segundo lugar, o MDL (transações primárias + secundárias), com participação de $29 \%$ do total.

Os mercados voluntários ${ }^{64}$ também cresceram, com valores de transações estimadas da ordem de US\$100 milhões, em 2006, e valores recordes comercializados no Chicago Climate Exchange (CCX) e no New South Wales Market (NSW). Os projetos de Implementação Conjunta, vinculados às chamadas economias de transição ${ }^{65}$ também mostraram avanços em 2006, 16,3 $\mathrm{MtCO}_{2}$-eq comercializadas, representando um crescimento $45 \%$ acima daquelas registradas em 2005.

\footnotetext{
63 - State and Trends of the Carbon Market, 2007

64 - Mercados Voluntários: Chicago Climate Exchange (CCX), New South Wales Market (NSW), UK ETS. Mais detalhes sobre os mercados voluntários ver IETA (State and trends of the carbon market ), 2007, p.17-19.

65 - Países EIT: Bulgária, Croácia, Rep. Tcheca, Estônia, Latvia, Hungria, Polônia, Romênia, Rússia, Eslovênia, Eslováquia, Ucrânia.
} 
Tabela 7 - Mercado de carbono: volumes $\left(\mathrm{MtCO}_{2}\right.$-eq) e valores (US\$) em 2005 e 2006

\begin{tabular}{ccccc}
\hline & \multicolumn{2}{c}{2005} & \multicolumn{2}{c}{2006} \\
\cline { 2 - 5 } & Volume & Valor & Volume & Valor \\
\hline EU ETS & 321 & Permissões & \\
\hline New South Wales & 6 & 5908 & 1.101 & 24.357 \\
Chicago Climate & 1 & 3 & 20 & 225 \\
UK ETS & 0 & 1 & 10 & 38 \\
\hline Sub-Total & 328 & 7.971 & 1.131 & 24.620 \\
\hline MDL Primário & Transações Baseadas nos Mecanismos & \\
\hline MDL Secundário & 341 & 2.417 & 450 & 4.813 \\
JI & 10 & 221 & 25 & 444 \\
Outros Mecanismos & 11 & 68 & 16 & 141 \\
\hline Sub-Total & 20 & 187 & 17 & 79 \\
TOTAL & 382 & 2.894 & 508 & 5.477 \\
\hline
\end{tabular}

Fonte: Capoor e Ambrosi, 2007, p.3 (tradução nossa)

Os preços praticados nesses mercados, de acordo com Haites (2007), são mais estáveis na comparação com a volatilidade de preços observada no mercado EU ETS. A maioria dos CER transacionados variou entre US\$ 8 a 14, elevando a margem para US\$11, em 2006. A média de preços praticada no mercado de projetos baseados em Implementação Conjunta foi da ordem de US\$ 9 .

Ainda segundo Haites (2007), a estimativa de receitas com a venda de CER registrados em 2006 é 1 a 1,5 bilhão de dólares por ano, para um total investido nesses projetos de cerca de US $\$ 7$ bilhões. Desse total, 5,7 bilhões de dólares são investimentos de projetos de energia renovável e eficiência energética, o que, de acordo com o mesmo autor, é um volume comparável ao que foi investido, em 2006, em assistência oficial, cerca de 2 bilhões de dólares e pelo investimento privado, 6,5 bilhões de dólares, em projetos desse tipo, em todos os países em desenvolvimento.

Os governos dos países desenvolvidos são os maiores compradores de CER diretamente ou através dos fundos. Haites (2007) estima que esses governos comprem em torno de $45 \%$ dos compromissos estimados para 2008-2012. 
A expectativa é que a oferta de CER para o primeiro período de compromisso (2008-2012) atenda plenamente aos compromissos dos países listados no Anexo $B$, a menos que o governo canadense mude a sua posição de não comprar certificados no âmbito do Protocolo de Kyoto. Nas Tabelas 8 e 9 algumas estimativas de demanda e oferta, elaboradas por instituições que acompanham o mercado de carbono.

Tabela 8 - Estimativa da demanda das unidades de Kyoto em $2010\left(\mathrm{MtCO}_{2}\right.$-eq)

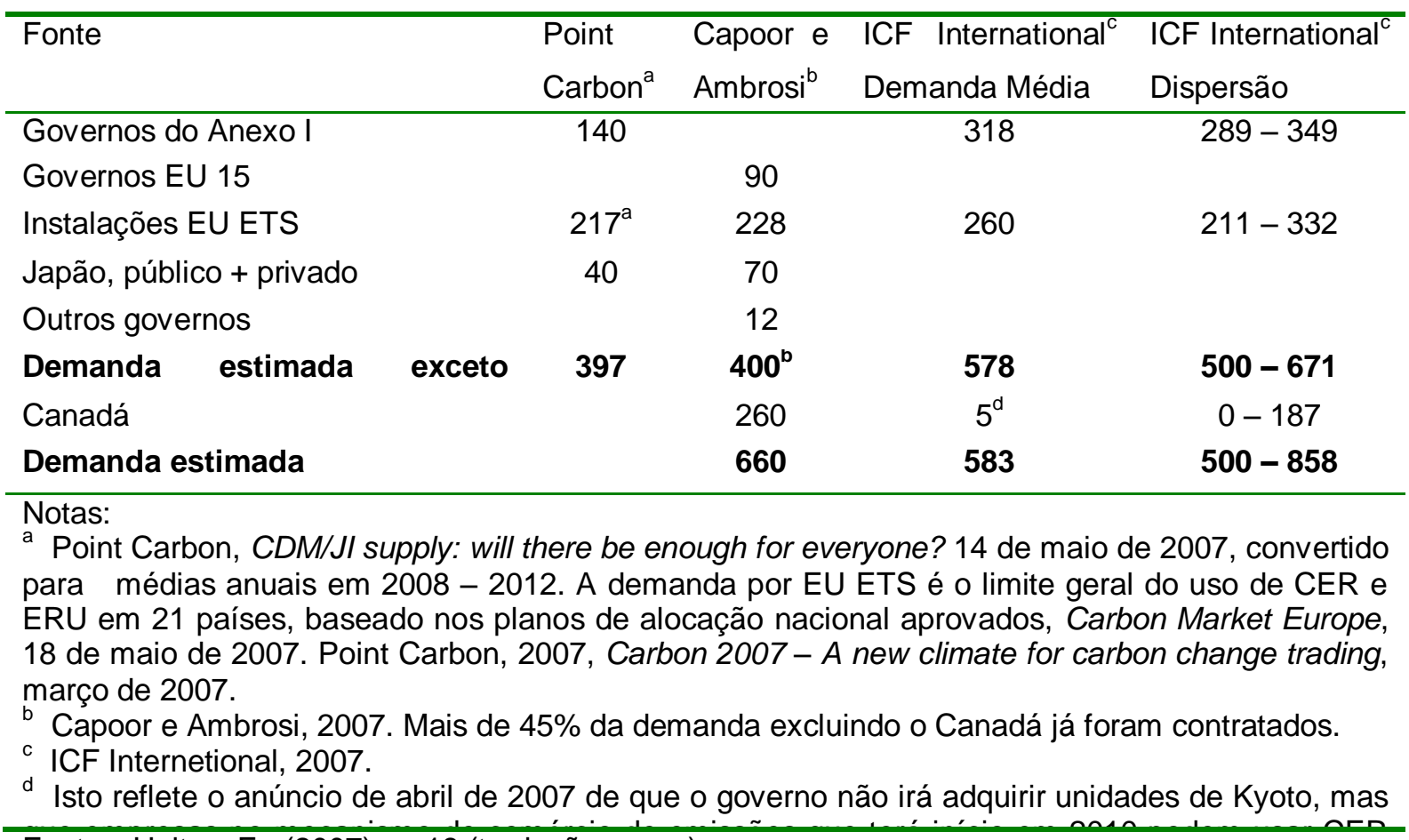

Fontes: Haites, E., (2007), p. 18 (tradução nossa)

Não se espera alterações significativas na demanda por unidades antes de 2010. Alterações poderão ocorrer se o sistema de comercialização EU ETS for expandido com a inclusão da aviação e se os novos sistemas de comercialização da Austrália e Estados Unidos permitirem o uso das unidades geradas no âmbito do Protocolo de Kyoto. O ICF estima que poderá chegar a $30 \mathrm{MtCO}_{2} /$ ano a demanda de CER e ERU do Regional Greenhouse Gas Iniciative (RGGI) dos Estados Unidos, entre 2008-2012. 
Tabela 9 - Estimativa da oferta das unidades de Kyoto em $2010\left(\mathrm{MtCO}_{2}\right.$-eq/ano)

\begin{tabular}{|c|c|c|c|c|}
\hline Fonte & $\begin{array}{l}\text { Point } \\
\text { Carbon }^{\mathrm{a}}\end{array}$ & $\begin{array}{l}\text { Capoor e } \\
\text { Ambrosi }^{\text {b }}\end{array}$ & $\begin{array}{c}\text { ICF International } \\
\text { Oferta Média } \\
\end{array}$ & $\begin{array}{c}\text { ICF International }^{\mathrm{C}} \\
\text { Dispersão }\end{array}$ \\
\hline \multicolumn{5}{|l|}{ Mecanismo de Desenvolvimento } \\
\hline Pipeline abril de 2007 & 460 & & & \\
\hline Projetos Adicionais & 240 & & & \\
\hline Reduções Projetadas & 700 & & & \\
\hline Estimativa de & 330 & $300^{\mathrm{b}}$ & & \\
\hline \multicolumn{5}{|l|}{ Implementação Conjunta } \\
\hline Pipeline abril de 2007 & 46 & & & \\
\hline Projetos Adicionais & 55 & & & \\
\hline Reduções Projetadas & 101 & & & \\
\hline certificados & 60 & 40 & & \\
\hline Sub-Total de & 390 & 340 & 340 & $220-450$ \\
\hline \multicolumn{5}{|l|}{ Excedente de AAU } \\
\hline Rússia & $950^{\mathrm{d}}$ & 640 & & \\
\hline Ucrânia & $300^{d}$ & 440 & & \\
\hline Outros & $400^{\mathrm{d}}$ & 340 & & \\
\hline Sub-Total AAU & 1.650 & 1.420 & $400^{c}$ & $240-600^{c}$ \\
\hline Total & 2.040 & 1.760 & 740 & $460-1050$ \\
\hline \multicolumn{5}{|c|}{$\begin{array}{l}\text { Notas: } \\
\text { a Point Carbon, CDM/JI supply: will there be enough for everyone? } 14 \text { de maio de } 2007 \text {, convertido } \\
\text { para médias anuais em } 2008-2012 \text {. } \\
\text { b Capoor e Ambrosi, } 2007 . \text { Os números para CER são baseados no CDM Pipeline (Fenhann) de maio } \\
\text { de } 2007 \text {, ajustado para valores observados e sem alocações para projetos adicionais. } \\
\text { c ICF Internetional, } 2007 \text {. As AAU são apenas as unidades vendidas por Green Investment Schemes e } \\
\text { foram convertidos para médias anuais. }\end{array}$} \\
\hline
\end{tabular}

Os analistas chamam a atenção para o fato de que a oferta potencial de CER pode elevar-se, significativamente, com a implementação de projetos de florestas e reflorestamento, projetos de destruição de HFC, captura e armazenamento de $\mathrm{CO}_{2}$ ou de projetos de redução do desmatamento. No entanto, o principal potencial de oferta adicional desse mercado são as Assigned Amount Units (AAU) asseguradas pelos países do leste europeu.

Ainda segundo as análises desenvolvidas por Haites (2007), as AAU serão usadas em períodos futuros e as CER e Emission Reduction Unit (ERU) provavelmente serão usadas para fazer face aos atuais compromissos dos países do Anexo B. O volume de AAU associado a uma baixa demanda poderá afetar o mercado de carbono na próxima década. Apenas na hipótese de um 
rápido crescimento da demanda pós-2012, a oferta adicional de AAUs seria rapidamente absorvida.

A oferta de CER e ERU poderá ainda ser afetada, considerando os seguintes pontos:

$\checkmark$ Incerteza sobre o pós-2012, que desestimula a implementação de projetos com payback mais longos e, conseqüentemente, o fluxo de novos projetos;

$\checkmark$ Possibilidade de revisões das emissões de CER e ERUs de projetos de baixo risco;

$\checkmark$ Possibilidade de mudanças no marco regulatório do MDL para ampliar a distribuição dos projetos em favor de projetos que apresentem mais crescimento dos benefícios.

Apesar dessas incertezas, os analistas esperam que a oferta seja suficiente para cobrir a demanda para o primeiro período de compromisso. A expectativa quanto aos preços praticados para CER/ERU e AAU é que eles não caiam. Primeiro, porque as concessões do EU fase I não podem ser usadas após 2007, então elas não terão valor no final do período, segundo porque as unidades de Kyoto, ao contrário, podem ser usadas após 2012.

As expectativas para 2030 são muito elásticas, variando em torno de estimativas de demandas muito baixas, que consideram que o fluxo atual dos projetos MDL é suficiente para atender a demanda em 2030, até expectativas muito elevadas, que projetam demanda da ordem de 100 bilhões de dólares por ano em 2030. Essas projeções de demanda alta supõem que países como Austrália e Estados Unidos assumam compromissos ambiciosos de redução das emissões dos GEE. $\mathrm{Na}$ Tabela 10 as estimativas para o mercado de carbono para 2010 e 2030. 
Tabela 10 - Estimativa de preços das unidades de Kyoto em 2010 e 2030

\begin{tabular}{|c|c|c|c|c|}
\hline Ano & Mercado & $\begin{array}{l}\text { Vendas } \\
\text { (US\$2006 } \\
\text { bilhões) }\end{array}$ & $\begin{array}{l}\text { Quantidad } \\
\text { e } \\
\left(\mathrm{MtCO}_{2}-\mathrm{eq}\right)\end{array}$ & $\begin{array}{c}\text { Preço } \\
\left(U S \$_{2006} / \mathrm{tCO}_{2-}\right. \\
\text { eq) }\end{array}$ \\
\hline 2010 & $\begin{array}{l}\text { Atendimento por participantes do Anexo } \\
\text { I ao Protocolo de Kyoto (principalmente } \\
\text { MDL e IC) }\end{array}$ & $\begin{array}{l}10 \text { a } 15 \\
(5 \text { a } 25)\end{array}$ & 400 a $600^{66}$ & $\begin{array}{c}23,60 \\
(13,50 \mathrm{a} \\
33,75) \\
\end{array}$ \\
\hline \multirow[t]{3}{*}{2030} & $\begin{array}{l}\text { Compras por atuais participantes do } \\
\text { Anexo I pela Convenção de países em } \\
\text { desenvolvimento }\end{array}$ & & & \\
\hline & Estimativa inferior & $\begin{array}{l}10 \text { a } 15 \\
(5 \text { a } 25)\end{array}$ & 400 a 600 & $\begin{array}{c}23,60 \\
(13,50 \mathrm{a} \\
33,75)\end{array}$ \\
\hline & Estimativa superior & $\begin{array}{c}100 \\
(90 \text { a 125) }\end{array}$ & $\begin{array}{c}4000 a \\
6000\end{array}$ & $\begin{array}{c}23,60 \\
(13,50 \mathrm{a} \\
33,75)\end{array}$ \\
\hline
\end{tabular}

Fonte: Haites, 2007, p. iv (tradução nossa)

Os mecanismos do Protocolo de Kyoto (MDL, IC e ME) e o sistema de comercialização estabelecido pelos países do Anexo B (EU ETS) dominarão o mercado entre 2008-2012, com ênfase para as perspectivas de crescimento do sistema de comercialização das EU ETS pela possibilidade da inclusão de países como a Noruega, Islândia e Turquia, o link com o sistema de comercialização da Suíça e a cobertura da aviação começando em 2011.

As previsões para os mercados voluntários apontam para um rápido crescimento no volume das transações. As vendas estimadas em 2006 de 13,4 $\mathrm{MtCO}_{2}$ atingiriam uma média anual de $250 \mathrm{MtCO}_{2}$, entre 2008 e 2012, com preços médios variando dos atuais US\$4/tCO (2006) para US\$10/tCO 2 (2008-2012). Confirmando-se essas expectativas o mercado voluntário representará $15 \%$ do mercado total.

66 - Sem considerar o governo canadense. 


\subsection{Balanço do MDL no Brasil}

Como anteriormente discutido, o MDL é um mecanismo de flexibilização, do qual podem participar os países não Anexo 1, e que como objetivo central ajudar os países desenvolvidos, em caráter suplementar, a cumprirem suas metas quantificadas de reduções das emissões dos GEE, por meio da certificação de projetos de redução de emissões implementados nos países em desenvolvimento e a posterior venda das reduções certificadas de emissão aos países listados no Anexo 1. As reduções de emissões devem ser adicionais, garantir benefícios reais, mensuráveis e de longo prazo para a mitigação das mudanças climáticas (MCT, 2009) ${ }^{67}$.

Em setembro de 2008, com 346 projetos no pipeline do MDL, o Brasil ocupava o 3o lugar, sendo precedido, em número de projetos, pela China e Índia, que apareciam em primeiro e segundo lugar, respectivamente. Desses, 156 projetos brasileiros foram registrados e 31 estão solicitando o registro.

A CIMGC aprovou 203 e mais 8 encontram-se em revisão. Por escopo setorial, a distribuição dos projetos brasileiros mostra uma enorme concentração de atividades vinculadas à energia renovável, $48 \%$, seguida dos projetos de suinocultura, com $17 \%$ e troca de combustível fóssil com $12 \%$.

Em termos de medidas de caráter nacional de estímulo ao desenvolvimento de projetos de MDL destacam-se a proposta de criação do Fundo Nacional sobre Mudança do Clima, com o objetivo de prover os recursos financeiros para implementar a Política e o Plano sobre Mudança do Clima (PMNC), 2008.

Outra iniciativa é o Pró-MDL criado com o objetivo de financiar projetos de préinvestimento e de desenvolvimento científico-tecnológico. Com o Pró-MDL, vários agentes envolvidos com o desenvolvimento de projetos de MDL poderão ter

67 - Disponível em: http://www.mct.gov.br/upd blob/0200/200842.pdf Acesso em 20/03/2009. 
acesso a recursos na forma de financiamento (reembolsáveis) e não reembolsáveis (MMA, 2008).

Finalmente existe a cooperação internacional a partir da qual o Brasil vem estabelecendo projetos de cooperação com países, como Canadá, Dinamarca, Espanha, França, Holanda, Itália, Japão, Portugal e Reino Unido, "em alguns casos por meio de Memorandos de Entendimento para cooperação nas áreas de mudança do clima e execução de projetos de Mecanismo de Desenvolvimento Limpo - MDL" (MMA, 2008, p.122).

Estima-se que em todo o mundo, no primeiro período de obtenção de crédito (2008-2012), algo em torno de 5,4 $\mathrm{GtCO}_{2}$-eq devem ser evitadas, média anual de 660 milhões de $\mathrm{tCO}_{2}$-eq ${ }^{68}$, com a China sendo responsável por mais de 2,5 $\mathrm{GtCO}_{2}$-eq (47\%), a Índia com 1,3 $\mathrm{GtCO}_{2}$-eq (25\%) e o Brasil com 0,331 $\mathrm{GtCO}_{2}$ eq (6\%). O México e a Coréia do Sul aparecem em quarto e quinto lugares, com $3 \%$ e $2 \%$, respectivamente. (MCT, 2009) ${ }^{69}$

Como se pode observar na Tabela 11, a distribuição dos projetos brasileiros por tipo de atividade mostra que os projetos de redução de $\mathrm{N}_{2} \mathrm{O}$ e de aterro sanitário embora apareçam em menor quantidade são responsáveis por uma grande parcela de emissões reduzidas. Na outra ponta se encontram os projetos de energia renovável, suinocultura, troca de combustível fóssil e eficiência energética, que embora mais numerosos, reduzem volumes menores de emissões. Ou seja, $10 \%$ dos projetos (redução de $\mathrm{N}_{2} \mathrm{O}$ e aterro sanitário) são responsáveis por $39 \%$ das emissões anuais reduzidas, enquanto que os projetos que representam $77 \%$ do número total de projetos reduzem $53 \%$ das emissões anuais a eles associadas.

\footnotetext{
68 - Dividindo-se as toneladas a serem reduzidas no primeiro período de obtenção de créditos pelo número de anos (7 ou 10) obtém-se uma estimativa anual de redução esperada (MCT, 2009). ${ }^{69}$ - Status dos Projetos de MDL no Brasil, atualizado em fevereiro de 2009.
} 
Tabela 11 - Distribuição das atividades de projeto no Brasil por tipo de projeto

\begin{tabular}{|c|c|c|c|c|c|c|}
\hline $\begin{array}{c}\text { Projetos em } \\
\text { Validação/Aprovação }\end{array}$ & $\begin{array}{l}\text { Número } \\
\text { de } \\
\text { projetos }\end{array}$ & $\begin{array}{l}\text { Redução } \\
\text { anual de } \\
\text { emissão }\end{array}$ & $\begin{array}{l}\text { Redução de } \\
\text { emissão no } \\
\text { 1o período de } \\
\text { obtenção de } \\
\text { crédito }\end{array}$ & $\begin{array}{l}\text { Número } \\
\text { de } \\
\text { projetos } \\
(\%)\end{array}$ & $\begin{array}{l}\text { Redução } \\
\text { anula de } \\
\text { emissão } \\
(\%)\end{array}$ & $\begin{array}{c}\text { Redução } \\
\text { de } \\
\text { emissão } \\
\text { no } 1^{0}= \\
\text { período } \\
\text { de } \\
\text { obtenção } \\
\text { de crédito } \\
(\%)\end{array}$ \\
\hline Energia renovável & 163 & 16.971 .045 & 119.565.353 & 48 & 39 & 36 \\
\hline Suinocultura & 58 & 2.854 .044 & 26.834 .620 & 17 & 7 & 8 \\
\hline Aterro sanitário & 30 & 10.156 .054 & 75.048 .699 & 9 & 24 & 23 \\
\hline Processos industriais & 7 & 832.946 & 6.131 .592 & 2 & 2 & 2 \\
\hline Eficiência energética & 21 & 1.490 .288 & 14.535 .192 & 6 & 3 & 4 \\
\hline Resíduos & 13 & 1.270 .537 & 10.255 .823 & 4 & 3 & 3 \\
\hline Redução de $\mathrm{N}_{2} \mathrm{O}$ & 5 & 6.373 .896 & 44.617 .272 & 1 & 15 & 14 \\
\hline $\begin{array}{c}\text { Troca de combustível } \\
\text { fóssil }\end{array}$ & 40 & 2.944 .658 & 24.541 .512 & 12 & 7 & 7 \\
\hline Emissões fugitivas & 1 & 34.685 & 242.795 & 0 & 0 & 0 \\
\hline Reflorestamento & 1 & 262.352 & 7.870 .560 & 0 & 1 & 2 \\
\hline
\end{tabular}

Fonte: MCT, 2009

Essa concentração aparece também na distribuição dos projetos por estado. Com efeito, oito estados brasileiros ${ }^{70}$ concentram $77 \%$ do total de projetos registrados no Brasil, sendo que quatro deles, SP, MG, RS e MT, absorvem 53\% do total. Exceto os projetos localizados nos estados do Mato Grosso e Mato Grosso do Sul, todos os demais se situam nas regiões sul e sudeste do Brasil, perfazendo $64 \%$ do total.

No setor energético a capacidade instalada dos projetos de MDL aprovados pela CIMGC alcançou 2,9 GW. Desse total, 2,6 GW encontram-se assim distribuídos: cogeração de biomassa, com 1,03 GW; hidrelétricas, com 0,95 GW; e PCH, com $0,60 \mathrm{GW}$.

Esses números revelam que o país já possui uma larga experiência com o MDL, colocando-se competitivamente como um importante ator, em nível mundial. Além disso, o país cresceu do ponto de vista institucional, com a criação de leis e diversas instâncias que regulamentam e operacionalizam o funcionamento do

\footnotetext{
70 - São Paulo, Minas Gerais, Rio Grande do Sul, Mato Grosso, Santa Catarina, Paraná, Goiás, Mato Grosso do Sul.
} 
MDL no Brasil, com ênfase na Comissão Interministerial de Mudança Global do Clima (CIMGC), que é a Autoridade Nacional Designada (AND), constituída nos termos do Anexo 1 da Decisão 17/CP7 dos Acordos de Marraqueche.

Vários trabalhos apontam que há no país diversas oportunidades para o desenvolvimento e implementação de projetos de MDL, especialmente com projetos para geração de energia elétrica a partir das fontes eólica, solar, biomassas e fonte hídrica, projetos de eficiência energética, aproveitamento de metano para co-geração de eletricidade e vapor, projetos no setor agropecuário, de reflorestamento e recuperação de matas ciliares, na área florestal e no tratamento de resíduos sólidos urbanos.

Aparentemente, milhões de $\mathrm{tCO}_{2}$ poderão ser evitadas se esse potencial for adequadamente explorado. O aprimoramento e intensificação do MDL não apenas elevará a contribuição do país no esforço global de combate ao aquecimento global, como também facilitará e ampliará a entrada de recursos externos e transferência tecnológica, com desdobramentos positivos sobre a formação de recursos humanos e geração de novos empregos. 


\section{Capítulo 4 Modelo de Equilíbrio Integrado}

Apresenta-se nesse Capítulo a metodologia do Modelo de Equilíbrio Integrado (MEI), adotado no presente trabalho para determinar o despacho futuro do parque gerador, inclusive das usinas térmicas (UTE) flexíveis convencionais ${ }^{71}$.

O MEI foi elaborado com base em um modelo elaborado por uma equipe de pesquisadores do Instituto de Economia (IE) da Universidade Federal do Rio de Janeiro (UFRJ) ${ }^{72}$, com o objetivo de prever as necessidades de expansão do SIN, em médio prazo, atender aos requisitos de energia elétrica do SIN, com garantia da segurança energética e ao menor custo total de operação do sistema elétrico, em cada período.

Por suas características e operacionalidade, o modelo permite obter, com razoável grau de confiança, a oferta de energia elétrica necessária, por fonte, para atender mensalmente aos requisitos do mercado previsto no período estudado, oferecendo resposta gerencial adequada para a metodologia proposta para estimar a linha de base dos projetos candidatos ao MDL a serem conectados ao SIN.

Com efeito, com vistas a verificar a adequabilidade do modelo às necessidades da presente pesquisa, foram comparados os resultados simulados pelo MEI com os dados realizados em relação à geração térmica convencional, os níveis dos reservatórios do SIN e preço spot da energia elétrica, entre 2004-2008.

71 - São consideradas UTEs flexíveis convencionais as centrais termelétricas movidas a óleo combustível, óleo diesel, carvão e gás natural, cujo despacho é realizado por ordem de mérito de custo. As usinas térmicas inflexíveis são aquelas cujo despacho é realizado de forma obrigatória, independentemente do custo do despacho a elas associados.

72 - O modelo original, desenvolvido sob a coordenação do professor Adilson de Oliveira, tem sido usado pelo IE em estudos e pesquisas acadêmicas, para gerar perspectivas quanto às principais variáveis de análise, como a segurança do abastecimento, evolução de preços e utilização de combustíveis, a partir de hipóteses quanto à expansão do parque de geração e o crescimento da economia. O modelo pode ser adaptado para analisar problemas específicos, como a avaliação da viabilidade econômica de uma central, ou para estimar as emissões dos GEE de sistemas elétricos, como a que foi desenvolvida no presente trabalho. 
Os resultados mostraram que o despacho térmico estimado pelo modelo foi apenas 9\% inferior ao valor observado, para o período entre 2004-2008, mostrando que os resultados obtidos apresentam satisfatória adequação à realidade, com viés conservador.

No que tange a série de níveis de reservatórios os resultados obtidos demonstram uma clara aderência relativamente aos níveis observados para as regiões Nordeste e Norte e discrepâncias em relação aos dados realizados para as regiões Sul e Sudeste. Esses desvios, no entanto, podem ser explicados pelo modo como o MEl faz a gestão dos reservatórios do sistema elétrico que, ao minimizar o risco de desabastecimento, opta por transferir uma grande quantidade de energia das demais regiões para o Sudeste, que é considerado o fator principal na manutenção da segurança energética. Isto explica o maior nível relativo de armazenamento observado nesta região, e menor nível, sobretudo, do reservatório da região Sul.

Os preços previstos para a energia elétrica não acompanharam estreitamente os preços observados, principalmente quando ocorrem oscilações bruscas neste último. Nestes casos, os preços simulados no MEI são influenciados pela energia armazenada no reservatório do Sudeste, que funciona como um "colchão de amortecimento" para o preço estimado pelo modelo, mantendo-o estável. Em sentido contrário, e coerentemente, o alto preço estimado pelo modelo, no primeiro semestre de 2004 da série do Sudeste, reflete o risco relacionado ao baixo nível observado no reservatório equivalente, neste semestre. Todos os resultados da validação são apresentados e analisados no item 4.4.2 desse Capítulo.

Destaque-se que embora o desenvolvimento do planejamento do setor elétrico brasileiro ter permitido um grande conhecimento sobre o comportamento futuro da capacidade da geração hidrelétrica brasileira, e dos avanços realizados no campo da informática ${ }^{73}$, o poder de previsão desses modelos enfrenta ainda

\footnotetext{
73 - Esses avanços referem-se aos desenvolvimentos de modelos sofisticados que simulam os comportamentos futuros da hidrologia e dos requisitos de energia elétrica, entre outras variáveis.
} 
muitas limitações. O despacho de usinas em sistemas elétricos com as características do SIN envolve variáveis de entrada com um alto grau de imprevisibilidade e, portanto, os resultados obtidos por meio dessas simulações devem ser vistos com cautela.

Com efeito, as variáveis dependem de um conjunto muito amplo de fatores, que se alteram mais rapidamente do que a capacidade que os modelos e analistas possuem em captá-las, a exemplo de mudanças de expectativas dos agentes que atuam no setor, variações inesperadas das afluências aos reservatórios em curto prazo, postergações de início e/ou finalização de obras de centrais elétricas importantes para o atendimento da demanda em razão de condicionantes políticos, ambientais, econômicos e regulatórios, entre outras.

Nessas condições, todos os resultados obtidos através das simulações realizadas com o modelo $\mathrm{MEI}$ estão sujeitos a variações, cujas magnitudes podem ser bastante significativas, a depender de como outras variáveis exógenas ao modelo se comportem.

É importante observar que as incertezas associadas às variáveis de entrada são comuns a qualquer modelo de simulação. Para reduzir essas incertezas é recomendável desenvolver, paralelamente à análise dos resultados encontrados com a aplicação de um modelo de simulação, análises qualitativas que levem em conta os desdobramentos futuros de aspectos políticos, ambientais, regulatórios e sociais que afetam os processos de planejamento e implementação dos projetos que fazem parte do portfólio de expansão do parque gerador, em médio e longo prazo.

Portanto, ainda que os resultados obtidos com a aplicação do modelo se mostrem, em princípio, coerentes, precisam ser vistos apenas como um possível cenário de futuro, cuja pertinência e probabilidade de ocorrer estão diretamente ligadas a um mínimo grau de estabilidade das condições a partir das quais este cenário foi desenhado. 


\subsection{Metodologia do Modelo de Equilíbrio Integrado}

O modelo elaborado tem como objetivo central atender aos requisitos de energia elétrica do SIN, ao menor custo total de operação do sistema elétrico, em cada período, respeitadas as seguintes condições:

a- A condição de equilíbrio se realiza em tempo real, ou seja, a oferta de energia elétrica é igual aos requisitos de mercado em cada período;

b- A geração hidrelétrica total em cada subsistema é sempre menor ou igual à soma da capacidade de geração das hidrelétricas localizadas nesse subsistema;

c- O despacho hidrelétrico é realizado com base na disponibilidade de água nos reservatórios equivalentes de cada submercado, sujeito a uma estimativa do valor da água acumulada nos reservatórios no momento do despacho;

d- O despacho das térmicas é realizado com base no custo variável unitário (CVU) declarado para o ONS; os intercâmbios entre os subsistemas são limitados pela capacidade de transmissão existentes ${ }^{74}$;

e- O modelo opera de forma a preservar níveis mínimos para o reservatório equivalente de cada submercado de modo a minimizar o risco de desabastecimento, utilizando como critério o período pluviométrico crítico.

O modelo permite aos usuários gerar cenários e previsões para as diversas variáveis de análise, como risco de desabastecimento, evolução de preços e utilização de combustíveis, a partir de hipóteses quanto à expansão do parque de geração, aos requisitos de energia elétrica e o crescimento da economia. Para efeito desta tese o modelo foi modificado para permitir a quantificação das emissões dos gases de efeito estufa (GEE), em particular, o dióxido de carbono

\footnotetext{
74 - Especificamente para esse trabalho não foi necessário levar em conta os limites de intercâmbio entre os subsistemas porque o SIN, para efeito de determinação da linha de base (LB) dos projetos de MDL, foi considerado como sistema único (MCT/CIMGC, 2007).
} 
$\left(\mathrm{CO}_{2}\right)$ emitido em decorrência da queima dos combustíveis para a geração de eletricidade das termelétricas que servem ao SIN. Nesse caso, os resultados são gerados a partir das estatísticas estimadas de despacho das centrais termelétricas flexíveis.

No modelo, o custo total da operação do sistema é dado pelos custos associados ao despacho das usinas hidrelétricas e das usinas termelétricas que compõem o parque gerador.

O custo das hidrelétricas é função da água acumulada nos reservatórios, cujos níveis variam, a cada período, em função:

a) Da utilização da água no período atual;

b) Do nível inicial dos reservatórios;

c) Das energias afluentes (ENAs) no período;

d) Dos preços dos combustíveis;

e) Dos vertimentos e das perdas registradas por evaporação ou pelas condições dos terrenos onde a água está acumulada.

Partindo da premissa de que os reservatórios devem ser mantidos em nível que garanta o equilíbrio entre a demanda e a oferta de energia elétrica ao longo de todo o período estudado, qualquer nível de água armazenada inferior a esse ponto de equilíbrio é considerado como indisponível para despacho. A diferença entre o nível real do reservatório e esse nível mínimo informa o volume de água disponível para ser usada na geração de energia elétrica.

Uma vez determinado esse volume, o valor da água disponível tem um comportamento exponencial, cujo valor máximo é representado pelo preço a partir do qual a sociedade prefere não consumir energia e cujo valor mínimo é aquele que representa 0 custo de oportunidade da água quando o reservatório está cheio (OLIVEIRA, et al., 2007). 
O custo das usinas térmicas convencionais é função dos preços do gás natural e dos outros combustíveis fósseis utilizados por essas UTEs. No presente trabalho, o custo das térmicas foi definido diretamente pelo custo variável unitário (CVU), não importando se movidas a gás natural ou a outros combustíveis fósseis (EPE, 2008a e 2008b).

\subsection{Estrutura e Operacionalidade do MEI}

O MEI foi composto em quatro módulos, a saber: módulo de ENA, de carga de energia, de oferta de capacidade, de vertimento e perdas, que dividem o processo de simulação por etapas. Através dessas etapas são obtidos os valores necessários para dar entrada no mecanismo de equilíbrio do sistema, alcançado por meio de interações entre oferta e demanda que são equilibradas em função do menor custo de suprimento, sujeito aos critérios de segurança. A Figura 4 mostra a estrutura e o fluxograma do modelo adotado nesse trabalho.

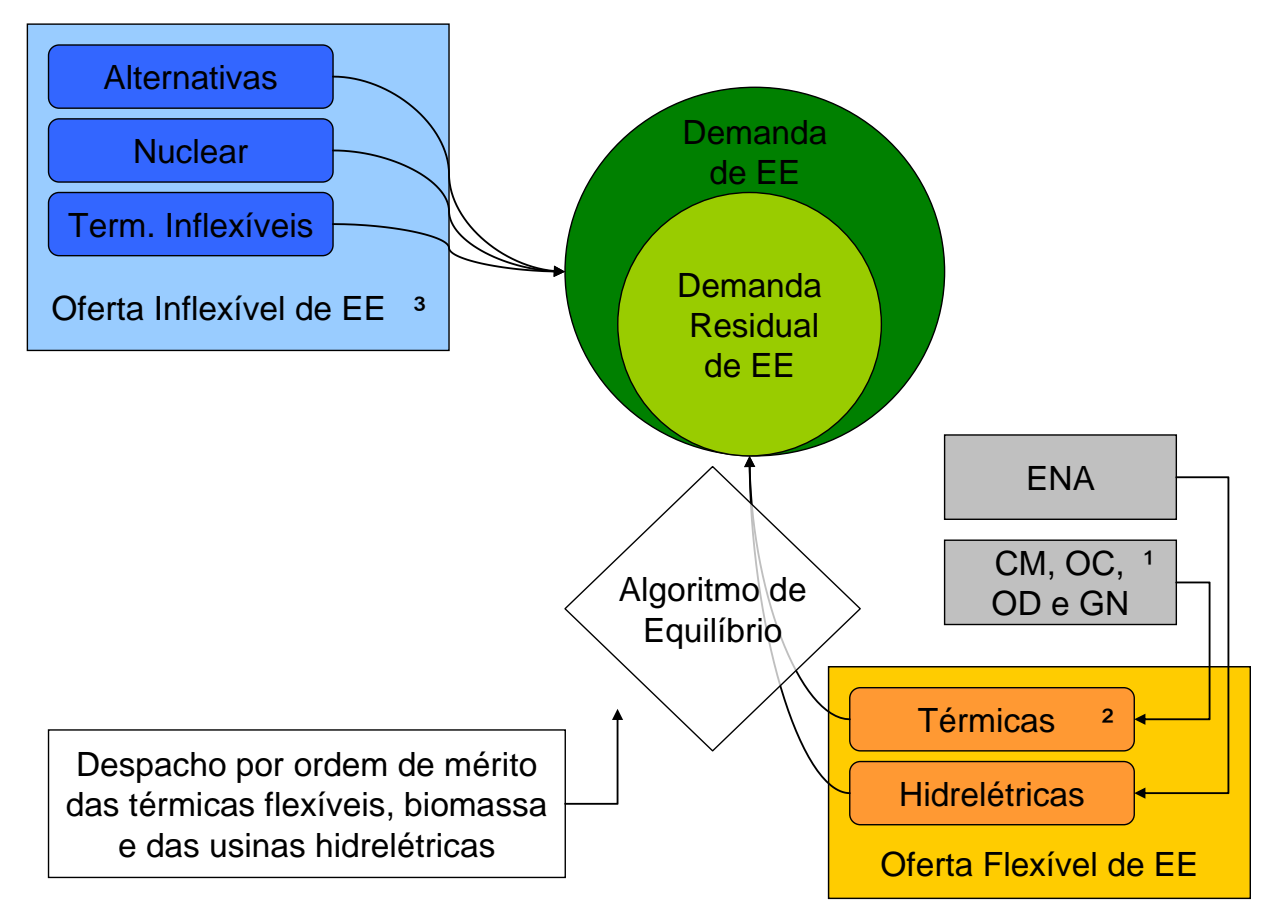

Figura 4 - Estrutura e Fluxograma do MEI

Fontes: (1) Termo de Compromisso Petrobras; (2 e 3) Nota Técnica de revisão do cálculo da garantia física das usinas (EPE, out/08); (3) PDEE 2007-2016. 
Em termos operacionais, o modelo trabalha com planilhas Excel com o apoio de microcomputador e utiliza modelos parametrizados com o uso de pacotes estatísticos mais sofisticados. As estimativas de emissões dos gases de efeito estufa (GEE) são geradas a partir dos dados de despacho estimado para as termelétricas.

O modelo opera obedecendo à seguinte seqüência:

1. A demanda mensal de energia elétrica é estimada por meio de um modelo econométrico para cada submercado;

2. É estimada a oferta inflexível de energia em cada submercado, definida pela oferta das centrais nucleares, energia de Itaipu, térmicas declaradas inflexíveis e fontes alternativas de energia despachadas na base;

3. A demanda residual (DR) de cada submercado que deve ser atendida pela hidrelétrica e pelas térmicas flexíveis é obtida pela diferença entre a demanda estimada na primeira etapa e a oferta inflexível;

4. O despacho hidrotérmico em cada submercado é estimado com base na curva de valor para a água disponível em seu reservatório equivalente e nos custos variáveis unitários (CVU) das térmicas disponíveis para despacho;

5. Os fluxos de energia entre as sub-regiões são estimados de forma a garantir a oferta de energia de menor preço disponível para as sub-regiões de preço mais elevado;

6. A oferta térmica das usinas a gás natural considerada pelo modelo especificamente para calcular as emissões dos GEE é definida com base no Termo de Compromisso da Petrobrás que estabelece a disponibilidade das usinas a gás natural (GN) até 2011. 
No Gráfico 11 uma representação simplificada de como a condição de equilíbrio do sistema elétrico é atendida. $O$ preço $\mathrm{P}^{*}$ de equilíbrio é encontrado por meio de uma função que valoriza a água disponível no reservatório. Ele é máximo quando está próximo ao custo do déficit e é mínimo quando representa o custo de oportunidade da água com o reservatório cheio. Todas as centrais cujos preços são inferiores ao preço de equilíbrio $\mathrm{P}^{*}$ são despachadas por ordem de mérito.

Observe-se que a curva de oferta integrada é composta de dois segmentos: o segmento representado pela linha azul da curva significa o despacho das UHE e a o segmento em vermelho o despacho das usinas termelétricas com preços menores que $\mathrm{P}^{*}$.

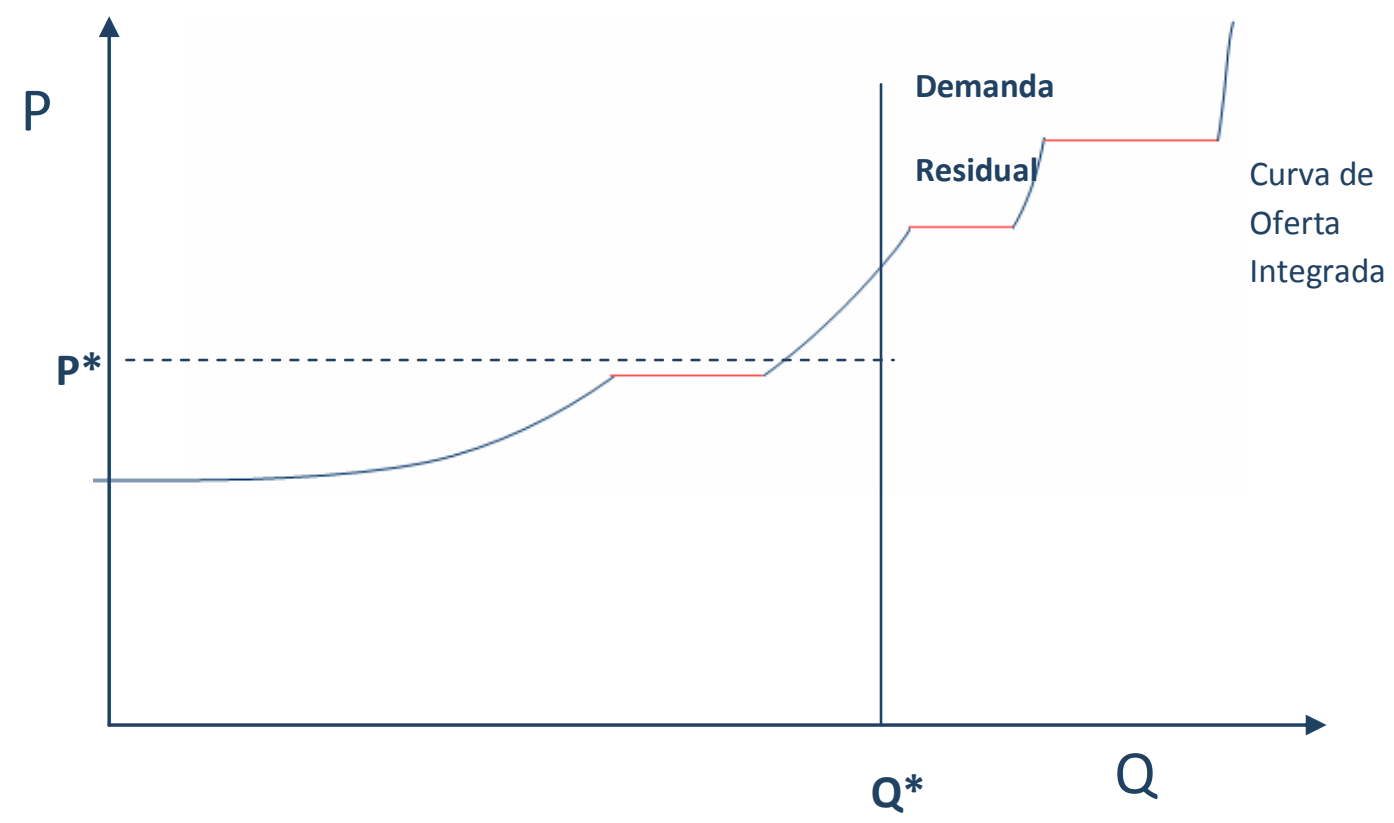

Gráfico 11 - Equilíbrio no mercado de energia elétrica Fonte: Oliveira, et al., 2008 
4.2.1 Módulo de Previsão dos Requisitos de Carga

O modelo de previsão dos requisitos de energia para cada subsistema do Sistema Interligado Nacional (SIN) considera como variáveis explicativas o comportamento da economia e o crescimento demográfico, trabalhando de forma agregada, em razão da disponibilidade e qualidade dos dados de carga fornecidos pelo ONS.

As previsões demográficas e os cenários utilizados sobre o comportamento da economia são aqueles formulados por organismos oficiais encarregados como o Instituto Brasileiro de Geografia e Estatística (IBGE), Instituto de Pesquisa Econômica Aplicada (IPEA) e Empresa de Pesquisa Energética (EPE).

Especificamente para atender aos objetivos do presente trabalho o modelo de previsão de carga não foi utilizado. Optou-se por considerar os requisitos de energia do SIN estimados no PDEE 2007-2016 com base na trajetória inferior de crescimento do mercado e projetar o ano de 2017 com base na taxa média de crescimento observada entre 2007- 2016.

\subsubsection{Módulo de ENA: Determinação da Oferta Hidrelétrica}

A oferta hidrelétrica é determinada por um modelo de energia natural afluente (ENA), que considera as observações hidrológicas do período entre 1964-2006 nos quatro subsistemas elétricos para projetar o comportamento futuro dessas ENA. As estimativas de ENA são corrigidas para incorporar a expansão do parque gerador. O modelo utiliza os subsistemas elétricos - Sul, Sudeste/CentroOeste, Nordeste e Norte - como unidades geográficas.

Uma vez que o modelo valoriza a geração hidrelétrica a partir do volume de energia disponível nos reservatórios, na razão inversa do nível observado em 
cada período, quando os reservatórios estão vazios, a produção hidrelétrica se reduz para permitir a acumulação de água, sendo despachadas as térmicas para atender a demanda. A curva de oferta térmica foi modelada a partir de cenários de expansão do parque gerador e dos preços dos combustíveis. (Oliveira, et al., 2008).

Para a modelagem da energia natural afluente o modelo utiliza os modelos autoregressivos quantílicos de ordem $p$ (ARQP), que, segundo seus autores, pela sua maior flexibilidade, "permitiu a obtenção de estimativas mais adaptadas às séries de ENA", registrando ainda que "os modelos adotados no NEWAVE são casos particulares desse approach" (OLIVEIRA, et al., 2008).

O Gráfico 12 apresenta os dados simulados segundo o modelo para o subsistema Sudeste de 1971 até os dias de hoje. Observa-se a semelhança entre a distribuição simulada e a original.
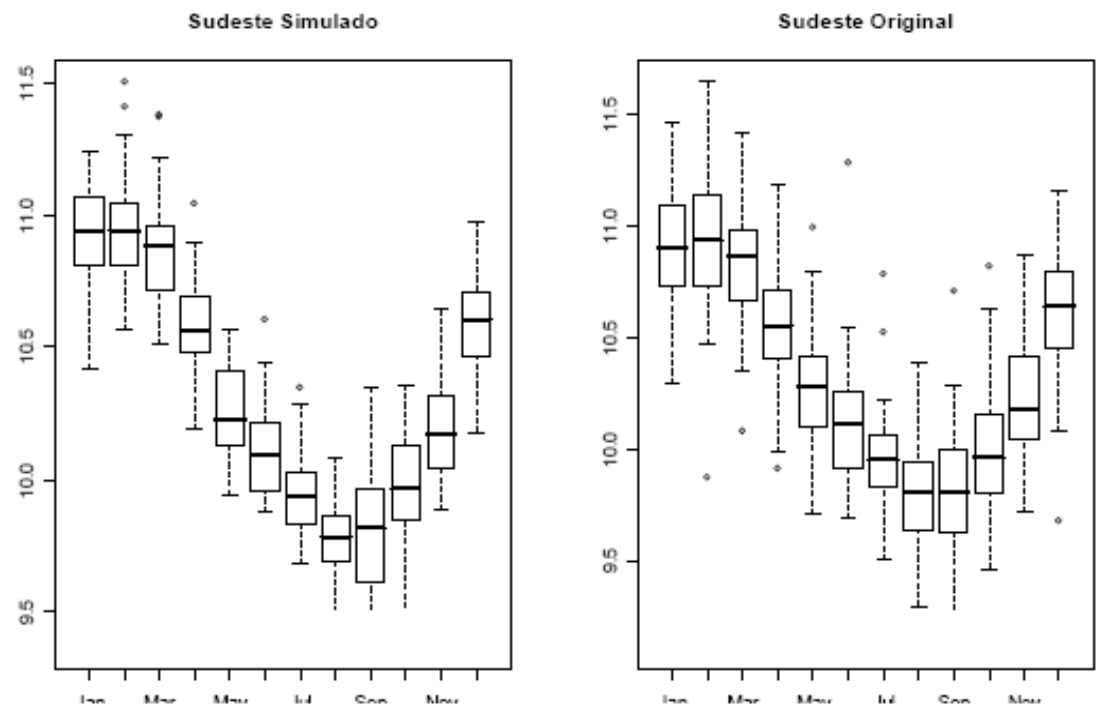

Gráfico 12 - Distribuição da ENA simulada e observada no SE (1971-2008) Fonte: Oliveira, A. et al., 2008 


\subsubsection{Módulo de Vertimento e Perdas}

Uma importante variável para determinar o equilíbrio entre oferta e demanda de energia elétrica é a informação sobre os níveis iniciais dos reservatórios equivalentes em cada período. Tais níveis podem ser fornecidos pelo usuário para qualquer cenário, sendo geralmente utilizado o último valor observado em cada um dos quatro reservatórios equivalentes que o modelo adota para realizar as simulações.

Como os volumes de geração são calculados em função da curva de custo futuro da água, ou do custo de oportunidade do uso da água e das alternativas de geração com o despacho flexível, para se obter o valor final do reservatório é preciso calcular o volume de água vertido em cada período.

O vertimento ocorre por diversas razões, inclusive a de manter a vazão das bacias hidrográficas, assegurando a água necessária para outros fins que não o de geração de eletricidade e para o objetivo de observar um nível máximo de armazenamento da água, para evitar que em períodos de alta hidraulicidade possa haver transbordamentos.

$\mathrm{Na}$ medida em que o vertimento corresponde, quantitativamente, a uma energia não gerada há uma associação inversa entre verter e gerar, que pode ser explicada também por outros fatores como o nível dos reservatórios no período $t$ qualquer, no volume de ENA previsto e numa componente sazonal.

As perdas por evaporação e por absorção do solo podem ser consideradas constantes, em média, ou variando em função dos níveis do reservatório. No modelo as perdas foram consideradas como uma parcela do vertimento.

Para estimar a água vertida e as perdas o modelo utiliza uma regressão linear simples, estabelecendo uma relação entre a sazonalidade, nível dos reservatórios no período dado e ENA do mesmo período. O modelo pressupõe uma continuidade no saldo de água, sendo o resultado a cada período igual ao 
período anterior somado ao balanço dos usos. Assim, os níveis dos reservatórios no período seguinte $(t+1)$ correspondem aos níveis observados no período atual (t), adicionado da energia afluente, subtraídos a geração realizada, o vertimento $e$ as perdas.

Para calcular o saldo do período seguinte é preciso ter o valor do vertimento e perdas. Por isso, e dada a relação existente entre os componentes deste saldo, estes são obtidos através da seguinte expressão:

$V_{t}+P_{t}=a_{t}+b R_{t}+c E N A_{t}-d G_{t}, \quad$ onde:

$a_{t}=$ constante sazonal

$\mathrm{R}_{\mathrm{t}}=$ reservatório no período $t$

$\mathrm{ENA}_{\mathrm{t}}=\mathrm{ENA}$ do período $\mathrm{t}$

$\mathrm{G}_{\mathrm{t}}=$ água utilizada nos reservatórios das usinas hidrelétricas para a geração de energia no período $\mathrm{t}$

$b, c$ e $d=$ regressores

Os dados estimados apresentaram um excelente ajuste quando confrontados contra os dados observados de vertimento e perdas no período entre 2000 e 2007. Uma afluência muito acima da média pode, entretanto, deslocar pontualmente estes resultados. Nesse caso, o vertimento cumpre o papel de preservar a segurança da bacia. Para modelar esses casos, aplicou-se no modelo um teto artificial para os reservatórios equivalentes, conforme observado nas séries históricas, simulando o que seria feito na realidade.

\subsection{Modelo Computacional de Equilíbrio Integrado}

O modelo de equilíbrio operacionaliza os módulos de oferta e demanda por energia elétrica, simulando mensalmente o equilíbrio para anos futuros (até 20 anos), com base na previsão de séries estocásticas da energia natural afluente (ENA), de demanda por energia elétrica, diversos bancos de dados de entrada e 
cenários definidos pelo usuário. As séries de ENA projetadas pelo MEI são apresentadas nos Gráficos 13, 14, 15, e 16.

O equilíbrio geral no modelo é realizado por meio de um balanço contábil de uso da água, que considera a ENA como variável do fluxo de entrada, considera como estoque, a água armazenada nos reservatórios equivalentes e como fluxo de saídas, a geração realizada, o vertimento e as perdas.

Para garantir a segurança no suprimento energético define-se, a priori, limite de segurança para a água disponível nos reservatórios equivalentes. Para que esse limite seja respeitado, uma fórmula exponencial de valoração da água disponível aumenta seu custo na medida em que se aproxima do nível-limite estabelecido.

Este mecanismo ainda que não impeça que o reservatório extrapole o limite mínimo, torna a água tão cara a partir deste ponto, que ela só será usada em casos extremos. O valor da água a este nível assemelha-se aos patamares estabelecidos para o custo de racionamento, e são, em geral, mais elevados que a mais cara das usinas térmicas.

A operação do modelo pode ser feita através de previsão com cenários prédefinidos, ou por simulação (através do Método de Monte Carlo). Recorrendo a simplificações que diminuem os requisitos de tempo e de equipamento para sua operação, embora não contemple todas as características dos modelos de operação do sistema elétrico e de gás natural, tem-se mostrado bastante robusto para simular adequadamente o comportamento futuro das variáveis mais importantes que envolvem o planejamento energético do SIN. 


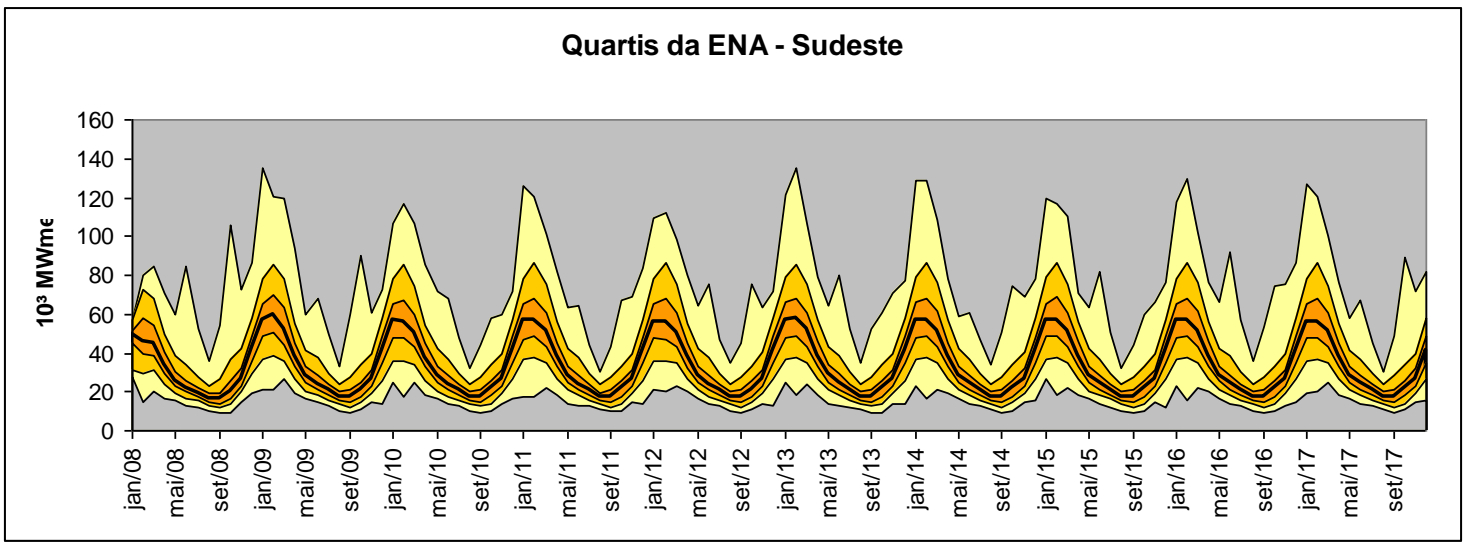

Gráfico 13 - ENA projetada para o Sudeste

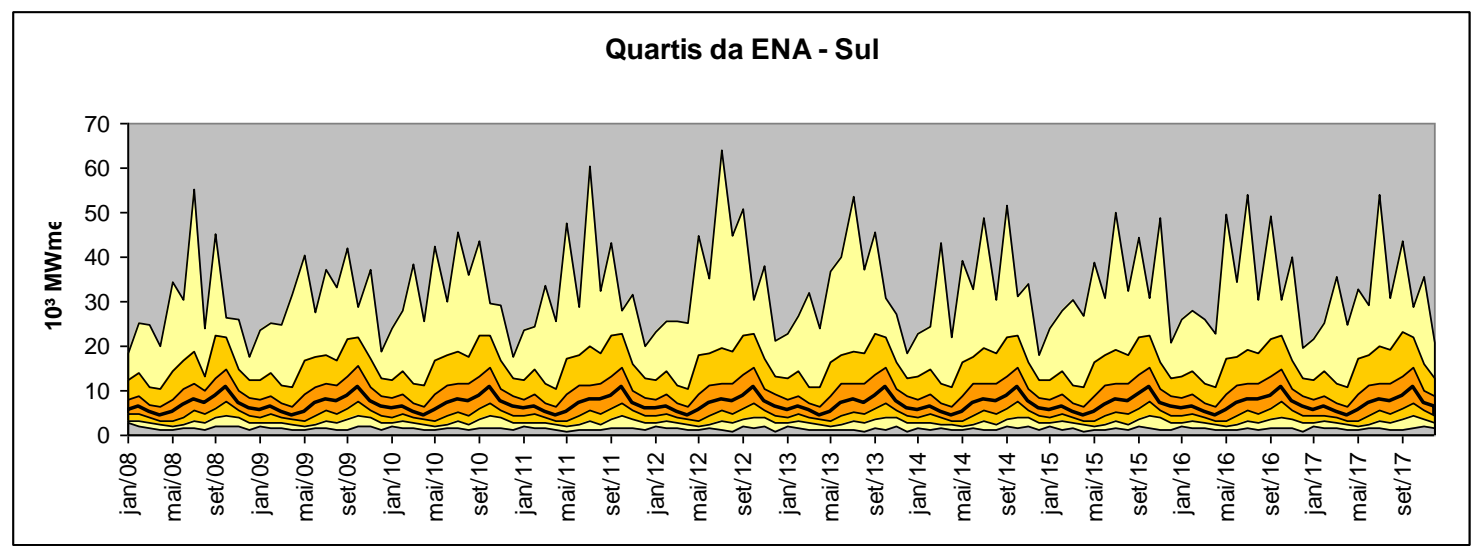

Gráfico 14 - ENA projetada para o Sul

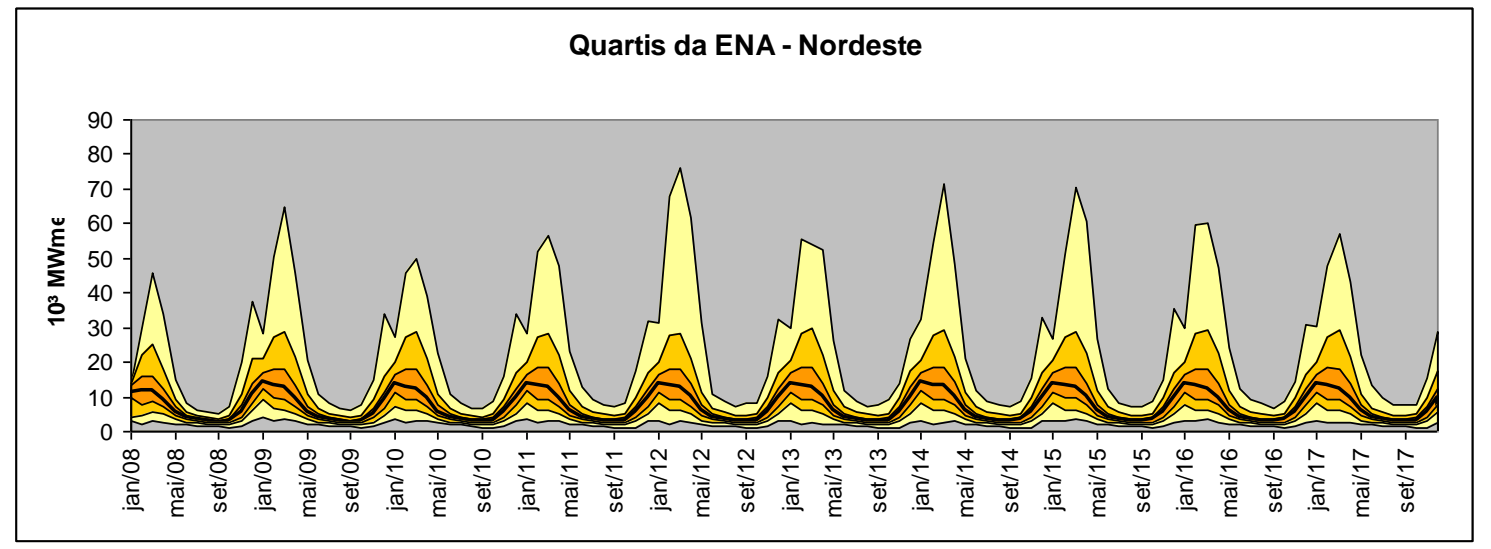

Gráfico 15 - ENA projetada para o Nordeste 


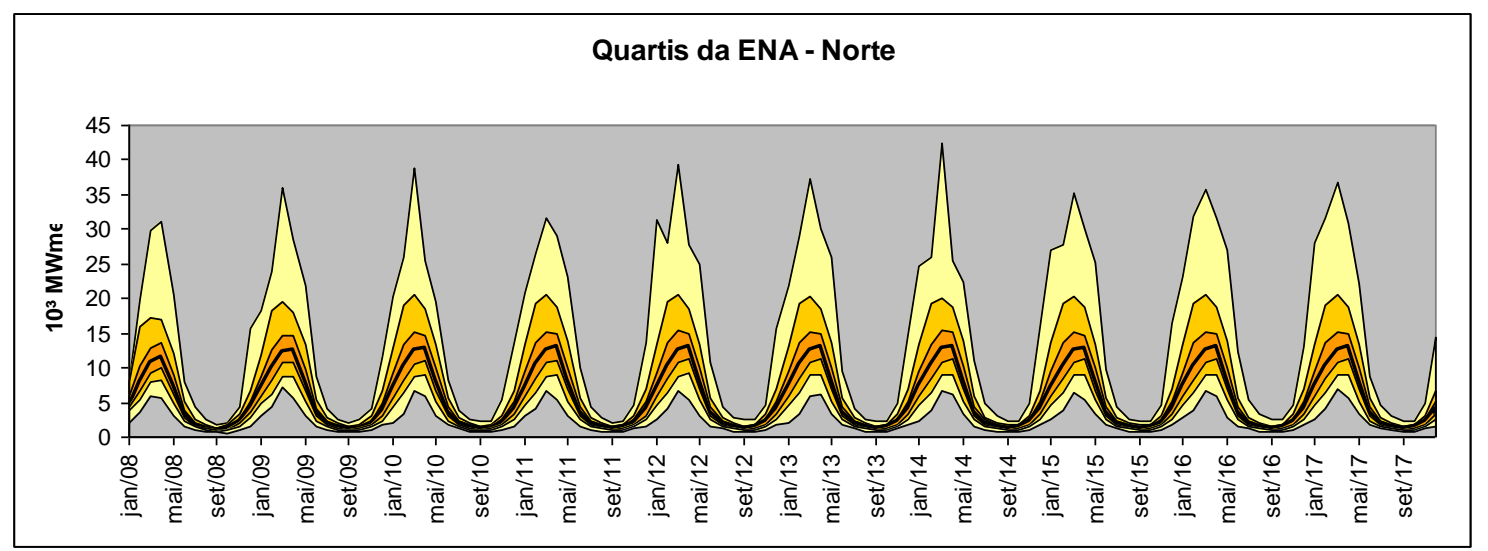

Gráfico 16 - ENA projetada para o Norte

\subsection{Validação do MEI}

O MEl, assim como outros que simulam o equilíbrio contábil entre oferta e requisitos de energia em sistemas elétricos predominantemente hídricos, como é o caso do SIN, assume premissas e trabalha com diversos módulos que estimam os comportamentos futuros das variáveis consideradas mais relevantes. Eles buscam determinar, em última instância, as $\mathbf{n}$ diferentes, porém equiprováveis, trajetórias de oferta de energia elétrica que o parque gerador atual e planejado é capaz de realizar, considerando as previsões anuais dos requisitos de energia elétrica dos mercados envolvidos e demais premissas relativas à segurança energética do sistema elétrico.

\subsubsection{Características do modelo NEWAVE versus MEI}

O modelo NEWAVE também possui em sua programação a simulação das séries de ENA, dos requisitos de energia e do vertimento. Ainda que cada um destes mecanismos possua diferenças ${ }^{75}$ com os respectivos módulos do MEl, o que se

\footnotetext{
75 - Pode-se citar como exemplo de diferença o fato do módulo de ENA do modelo MEI ser programado em torno de uma regressão quantílica, enquanto no modelo NEWAVE o modelo é
} 
obtém a partir deles são séries estocásticas, que por sua vez serão aplicadas no equilíbrio geral. Nesta etapa reside a maior diferença entre os dois modelos analisados.

O equilíbrio no modelo NEWAVE é obtido em função da minimização do custo futuro do sistema, baseado no custo de utilização de geração alternativa à hidroelétrica. Este mecanismo promove uma redução no custo de operação sem restrições no uso do reservatório para a segurança, desde que as simulações obtidas não apresentem déficit de energia em mais do que $5 \%$ das séries.

A constatação de que o uso indiscriminado dos recursos hídricos poderia colocar o sistema em risco de desabastecimento, uma vez que as ENA possuem alta variabilidade, levou a criação de um mecanismo auxiliar ao equilíbrio no modelo NEWAVE chamado de método CAR. Este adapta ao modelo uma penalização para o uso da água acima de um determinado patamar estabelecido previamente pelas curvas de aversão ao risco (ONS, 2004).

O método CAR fez com que apenas em alguns casos, o modelo "prefira" utilizar recursos de origem termelétrica por conta da penalidade estabelecida. Na prática, a aplicação do método CAR não solucionou o problema de segurança no abastecimento, fato que pode ser verificado pelo fato de o ONS realizar seguidamente o despacho fora do mérito ou por razão de segurança. Essa solução torna o problema do equilíbrio extremamente complexo e, em sua documentação, afirma-se que adotá-lo de forma precisa "poderia ser muito custoso computacionalmente" (ONS, 2004)

Em geral, quando a programação de despacho não viola as curvas de mínimo, o método CAR não é acionado. Mas quando o cálculo apresenta resultados que sejam inferiores à curva de aversão, então o cálculo é refeito a partir das penalidades adotadas. O problema ocorre quando, no segundo cálculo, novos valores de reservatórios futuros precisam ser estabelecidos, e a função de minimização de custos precisa ser reestimada para cada um dos usos dos 
reservatórios. Tendo em vista que esse procedimento requereria um esforço computacional extremamente moroso, o processo foi simplificado, utilizando o resultado de um cálculo dual apenas uma vez. Eventuais desalinhamentos dos resultados são ignorados.

É exatamente quando o sistema apresenta risco de desabastecimento que a precisão diminui. O modelo NEWAVE, tendo sido projetado para minimizar o custo do despacho, não favorece a aplicação das restrições de reservatórios preconizadas em uma metodologia simples. O próprio método CAR, ainda que fosse implementado para operar com máxima precisão, possui uma falha intrínseca de sinalização: só há penalização quando são ultrapassadas as curvas de aversão.

Em contrapartida, como o valor da água é em geral inferior ao das fontes alternativas de despacho, o modelo "prefere" utilizar água sempre que possível. Isto leva constantemente aos níveis mínimos de reservatório, e qualquer flutuação, quer seja nas ENA, quer seja na demanda por energia, quer seja no fornecimento de combustível para a geração termelétrica, expõe o sistema a um severo risco de desabastecimento. Em adição, provoca grande instabilidade no preço do mercado atacadista de energia, o preço spot.

Partindo de uma premissa radicalmente oposta, o MEl é formulado em torno da minimização do risco de desabastecimento. A água nos reservatórios é precificada principalmente por sua função de reserva futura de energia. Assim, baseado na escassez relativa (em função da expectativa de ENA futura) a energia armazenada possui um preço instantâneo que aumenta conforme seu uso. Ajustando as funções de valor da água para utilizar os mínimos conforme a curva de aversão ao risco, não acrescenta ciclos computacionais ao processo de equilíbrio, pelo contrário, simplifica-o. O mix do despacho é obtido através da comparação dos custos de geração alternativos ao hidrelétrico com o valor calculado da água. 
Este método não garante o custo mínimo de despacho, e pode ser argumentado que em situações onde a hidrologia é inesperadamente favorável ocorra "desperdício" de energia por conta da água vertida. Entretanto, o método oferece uma minimização do custo de despacho considerando o "preço" que se está disposto a pagar pela segurança no abastecimento e, levando-se em conta os custos do racionamento, parece uma melhor solução. Ademais, o processo possui a vantagem de ser computacionalmente simples e replicável o que para uma projeção de longo prazo para análise pode ser vantajoso.

Em paralelo com o modelo vigente, quando não há expectativa de desabastecimento, os preços calculados possuem as mesmas características distributivas. Entretanto, como a curva de valor da água é contínua, no modelo MEI a trajetória de preços não apresenta variações bruscas, o que favorece o investimento no setor.

O modelo MEl foi desenvolvido para uso acadêmico e para previsões de longo/médio prazo. Entretanto, sua metodologia de segurança de abastecimento é pautada em uma série de sugestões realizadas por especialistas para a melhoria do sistema atual de despacho.

\subsubsection{Vantagens e Validação do MEI}

O uso do MEI para estimar a geração termelétrica flexível, emissora dos GEE apresenta duas grandes vantagens em relação ao modelo NEWAVE:

Em primeiro lugar, a simplicidade da sua operação combinada com a utilização de pacotes estatísticos complexos, que garantem a confiabilidade e robustez aos resultados encontrados, torna o MEI um instrumento mais indicado para objetivos de pesquisas acadêmicas, a exemplo da pesquisa desenvolvida no presente trabalho. 
Segundo, porém não menos importante, a sua maior adequação aos propósitos de estimar o comportamento futuro das variáveis mais relevantes para o planejamento do setor elétrico nacional, em médio e longo prazo, na medida em que suas premissas e modelagens são focadas na segurança do abastecimento, garantindo que o comportamento de suas principais variáveis seja sustentável, sem apresentar alterações bruscas nas séries estimadas.

O MEl equaciona matematicamente a premissa de garantia da segurança energética, não permitindo que os reservatórios equivalentes operem em níveis críticos de armazenamento qualquer que seja o ano do período da projeção. Essa é uma importante vantagem quando se trata de construir cenários voltados para a tomada de decisões de investimentos, por agentes públicos ou privados, em projetos de expansão do parque gerador nacional.

Para validar o MEI no âmbito desse trabalho, optou-se por comparar os resultados encontrados a partir da simulação realizada com o uso do modelo com os resultados efetivamente observados, entre 2004-2008, em relação às seguintes variáveis: geração térmica convencional, níveis dos reservatórios e preço spot da energia elétrica.

Os resultados, que se encontram na Tabela 12, mostram que o despacho térmico estimado pelo modelo não foi muito diferente da geração térmica realizada. De fato, a geração média simulada para todo o período registrou um valor apenas $9 \%$ inferior ao valor observado. Em termos regionais essas diferenças são mais significativas. No Nordeste a geração total estimada foi $98 \%$ superior em relação aos valores efetivamente gerados. Na região Sul o valor estimado foi $50 \%$ inferior ao observado no mesmo período. 
Tabela 12 - Resultados comparados da validação

\begin{tabular}{|c|c|c|c|c|c|c|}
\hline \multicolumn{7}{|c|}{ Geração Térmica Convencional Observada (ONS MWmed) } \\
\hline & 2004 & 2005 & 2006 & 2007 & 2008 & Período \\
\hline SE & 2368 & 103 & 1000 & 986 & 2756 & 1629 \\
\hline Sul & 1041 & 1000 & 1171 & 1025 & 940 & 1035 \\
\hline NE & 368 & 291 & 125 & 114 & 461 & 272 \\
\hline SIN & 3778 & 2324 & 2298 & 2126 & 4158 & 2937 \\
\hline \multicolumn{7}{|c|}{ Geração Térmica Convencional Estimada (MEI MWmed) } \\
\hline & 2004 & 2005 & 2006 & 2007 & 2008 & Período \\
\hline SE & 1194 & 1041 & 1953 & 1792 & 2175 & 1631 \\
\hline Sul & 231 & 242 & 838 & 599 & 668 & 515 \\
\hline NE & 272 & 228 & 357 & 549 & 1290 & 539 \\
\hline SIN & 1698 & 1511 & 3149 & 2941 & 4134 & 2686 \\
\hline \multicolumn{7}{|c|}{ Relação Estimado / Observado } \\
\hline & 2004 & 2005 & 2006 & 2007 & 2008 & Período \\
\hline SE & 0,50 & 1,01 & 1,95 & 1,82 & 0,79 & 1,00 \\
\hline Sul & 0,22 & 0,24 & 0,72 & 0,58 & 0,71 & 0,50 \\
\hline NE & 0,74 & 0,79 & 2,85 & 4,80 & 2,80 & 1,98 \\
\hline SIN & 0,45 & 0,65 & 1,37 & 1,38 & 0,99 & 0,91 \\
\hline
\end{tabular}

Vale ressaltar, que essas diferenças já eram esperadas, uma vez que o modelo MEl pauta-se na manutenção de altos níveis de segurança, minimizando o custo de operação apenas após garantir o abastecimento. Ou seja, o modelo comanda o despacho preventivo de centrais térmicas com o objetivo de preservar o reservatório no futuro. Por possuir uma curva contínua de custo relativo da água armazenada, o MEl aumenta gradualmente o despacho das centrais térmicas de acordo com o custo variável unitário (CVU) a elas associados.

No que tange a série de níveis de reservatórios, os resultados obtidos demonstram uma clara aderência relativamente aos níveis observados para as regiões Nordeste e Norte, Gráficos17 (c) e (d) discrepâncias importantes em relação às regiões Sul e Sudeste, Gráfico 17 (a) e (b). Esses desvios, no entanto, podem ser explicados por uma dificuldade inerente à modelagem para a região Sul, pelo fato de que, diferente das demais, as ENA da região Sul não apresentam uma curva "bem comportada" de ENA, em relação aos padrões de comportamento esperados para os períodos úmidos e secos. No Gráfico 17 (b) podem-se observar, claramente, as assimetrias observadas nessa região, que se reflete nas estimativas feitas pelo modelo. Além disso, o reservatório do Sul se 
configura cada vez mais como uma extensão dos reservatórios da região Sudeste, possuindo significativa capacidade de geração e de transmissão. Por isso, grande parte de sua geração hidrelétrica é transferida ao Sudeste, e o reservatório dessa região (Sudeste) é poupado.

Como a gestão dos reservatórios no modelo MEI parte de decisões econômicas relacionadas à minimização do risco de desabastecimento, isto leva a que uma grande quantidade de energia das demais regiões seja transferida para o Sudeste, poupando seu reservatório, que é considerado o fator principal na manutenção da segurança energética. Isto explica o maior nível relativo de armazenamento observado nesta região, e por conseqüência um maior vertimento de água. No Gráfico 17 (a) o vertimento está representado pela manutenção constante do nível do reservatório ao longo de um determinado período.

Um aspecto muito importante observado é o seguinte: como o modelo esteve livre para escolher utilizar a energia térmica disponível na região Sul e não o fez isto leva a crer que esta geração não é de fato fundamental para a manutenção da segurança energética do sistema. Este resultado específico aponta para o fato de que grande parte da energia, fortemente poluente, despachada de forma inflexível das centrais termelétricas movidas a carvão pode não apresentar uma vantagem real para o sistema, principalmente se considerados os custos gerados pela poluição.

Por conta desta política operativa, os preços previstos para a energia elétrica não acompanham estreitamente os preços observados, principalmente quando ocorrem oscilações bruscas neste último. Nestes casos, o reservatório do Sudeste funciona como um "colchão de amortecimento" para o preço, mantendoo estável (Gráfico 18 (a) e (b)). Em sentido contrário, e coerentemente, o alto preço estimado pelo modelo, no primeiro semestre da série do Sudeste, reflete o risco relacionado ao baixo nível observado no reservatório equivalente, neste mesmo período. 
Vale ressaltar por fim que, apenas para esta validação, toda a energia térmica convencional foi considerada flexível, ou seja, seu despacho realizado de acordo com o mérito de custo. Isto foi feito em função da dificuldade na obtenção dos dados de inflexibilidade para os meses observados entre 2004 e 2008. Se fosse considerada a inflexibilidade, a geração térmica na região Sul aumentaria e pouca alteração seria vista nas outras regiões. Isto, entretanto, não deve modificar de forma significativa os demais resultados e sua omissão não compromete as conclusões obtidas. Gráficos 20 (a), 20 (b) e 20 (c).
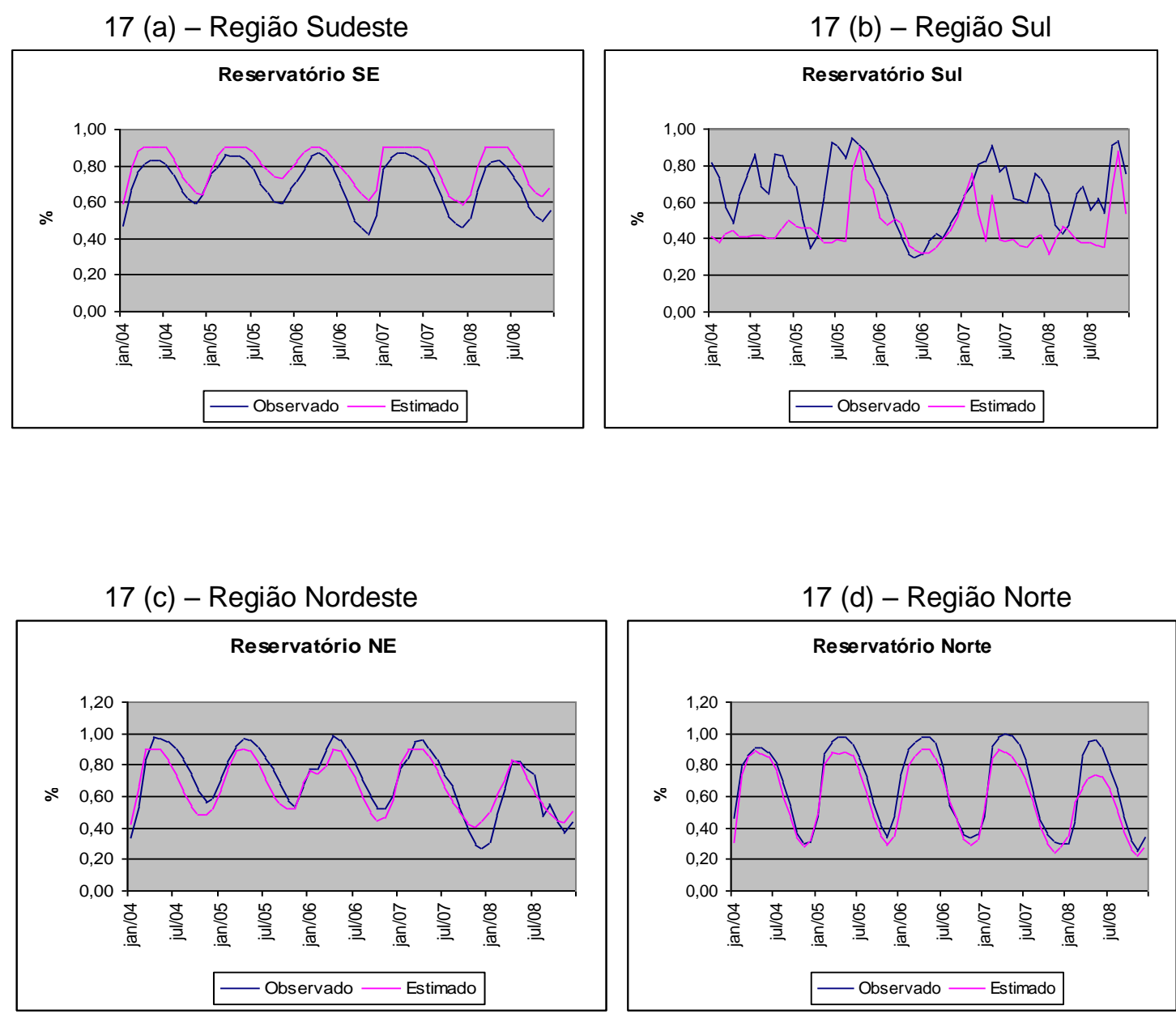

Gráfico 17 - Nível do reservatório observado e simulado por região 
18 (a) Região Sudeste

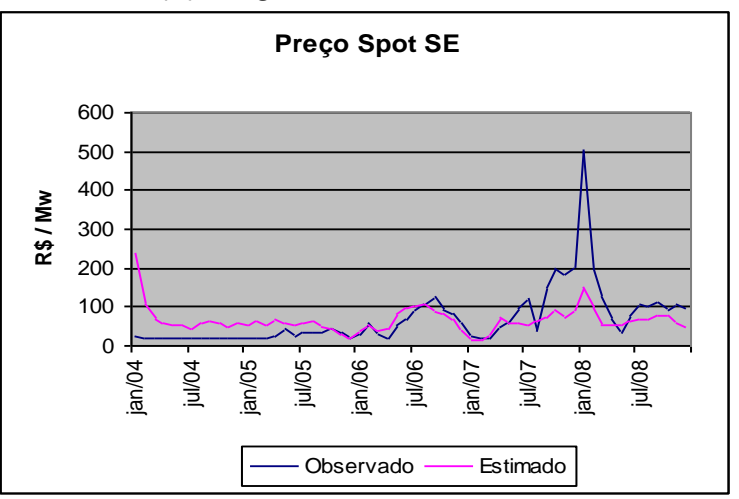

18 (b) Região Nordeste

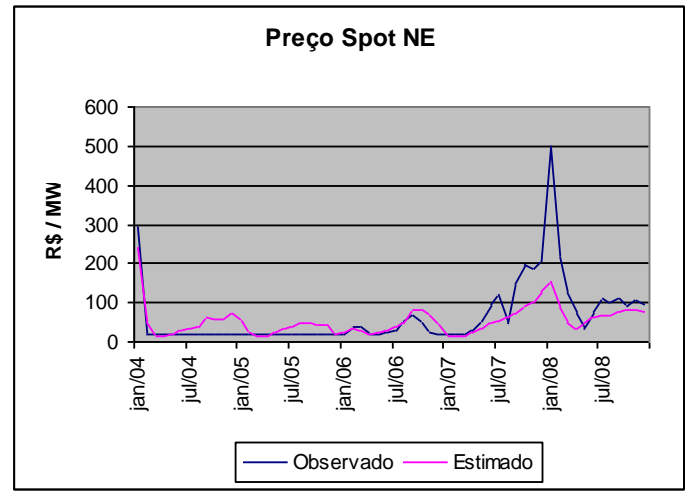

Gráfico 18 - Preço de curto prazo (spot) observado e simulado da energia elétrica ( $R \$ / M W h)$

19 (a) Região Sudeste

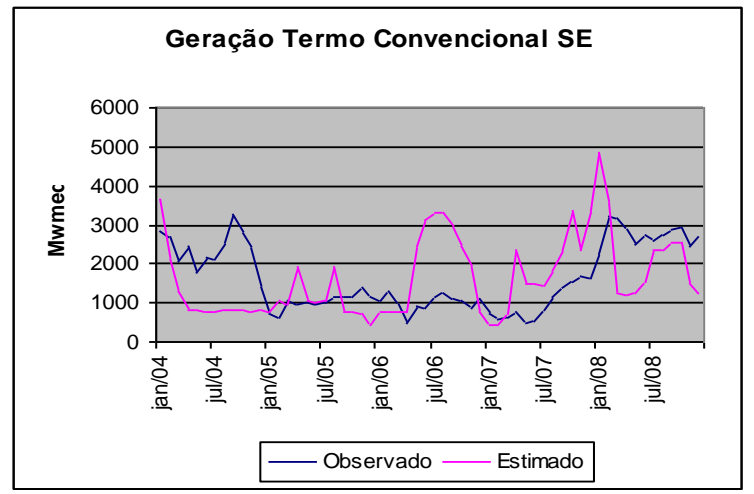

19 (b) Região Sul

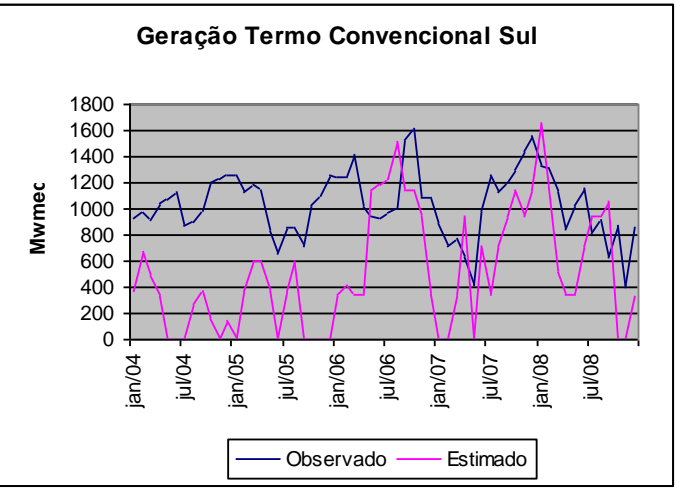

\section{9 (c) - Região Nordeste}

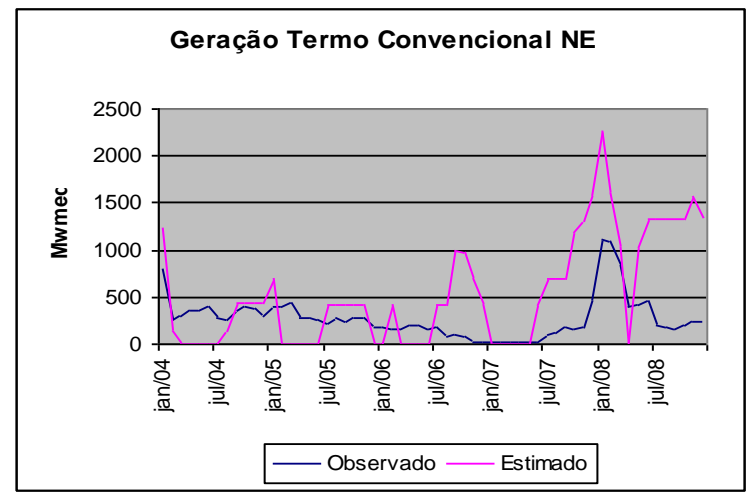

Gráfico 19 - Geração térmica convencional observada e simulada por região (MWmed) 


\section{Capítulo 5 Proposta de metodologia para contabilização de créditos de carbono de projetos de MDL em sistemas elétricos hidrotérmicos}

\subsection{Considerações Iniciais}

Conforme mencionado na Introdução, essa pesquisa tem como objetivo propor um novo referencial metodológico para estimar a linha de base (LB) de projeto candidato ao MDL a ser conectado a um sistema elétrico hidrotérmico, predominantemente hídrico, a partir de uma visão futura do mix das fontes energéticas que serão responsáveis pelas gerações de energia durante o período de obtenção de créditos relativo às atividades desse projeto.

Ela se apóia na percepção de que a linha de base determinada pelos métodos de cálculo sugeridos no Tool to calculate the emission factor for an electricity system $^{76}$ não expressa o comportamento futuro das emissões dos GEE, tendo em vista que todos os parâmetros são calculados com base nas emissões observadas. Ressalte-se que mesmo o fator de emissão da margem de construção se baseia nas emissões associadas às usinas mais recentemente construídas, tendo como referência o ano em que o projeto candidato ao MDL deslocará energia do sistema elétrico.

No Apêndice A desse trabalho são apresentados os principais conceitos, escopo, aplicabilidade, parâmetros e métodos de cálculo dessa metodologia, bem como a aplicação dela para calcular os fatores de emissão do Sistema Interligado Nacional (SIN) pela Comissão Interministerial de Mudança Global do Clima (CIMGC).

\footnotetext{
76 - Tool to calculate the emission factor for an electricity sistem, versão 01, aprovada na $35^{\text {a }}$ reunião do Comitê Executivo (CE) do Mecanismo de Desenvolvimento Limpo (MDL), em 19 de outubro de 2007.
} 
Em matrizes elétricas operadas majoritariamente por usinas termelétricas movidas a combustíveis fósseis, como é o caso da China e da Índia, não há dúvidas de que opções de abordagens baseadas em dados observados são adequadas e estimulam o desenvolvimento de projetos elegíveis como MDL. Em sistemas com este perfil, a expectativa é de que as matrizes se tornem mais limpas no futuro pela introdução de novas tecnologias de geração de energia elétrica e/ou pela substituição das fontes atuais de geração, seja pela implementação de amplos programas de eficiência energética. Nessas condições, é esperado que as emissões totais e as emissões por unidade de energia sejam menores com o passar do tempo, reduzindo, em conseqüência, a adicionalidade futura dos projetos MDL.

No entanto, em matrizes elétricas como a brasileira, onde se percebe que está havendo uma tendência de elevação das emissões dos GEE, a aposta na manutenção da atual participação das fontes que suprem ao SIN desconhece as sinalizações sobre a fossilização dessa matriz, cujas expressões mais imediatas são os resultados dos leilões de energia realizados e as crescentes e inevitáveis restrições ao uso mais intensivo dos recursos hidrelétricos existentes no país para geração de energia elétrica, em face aos impactos ambientais decorrentes da exploração desses recursos e/ou o esgotamento deles em diversas regiões do país.

Mais: de acordo com o Plano Decenal de Energia Elétrica 2008-2017, posto para consulta pública em dezembro de 2008 pelo Ministério das Minas e Energia (MME), das 82 novas termelétricas previstas, com potência total de 15.305 MW, 74 serão movidas a combustíveis não renováveis, a saber: 41 a óleo combustível, 20 a óleo diesel, 7 a gás natural, 5 a carvão e 1 a gás de processo. Apenas sete usarão biocombustível, prevendo-se ainda a construção de uma usina nuclear movida a urânio. Com base nos cálculos realizados pelo MME entre 2008 e 2017 as emissões de $\mathrm{CO}_{2}$ do $\mathrm{SIN}$ aumentarão $172 \%$, passando das atuais emissões de 14,4 milhões de toneladas para 39,3 milhões, em $2017^{77}$.

77 - Dados fornecidos pelo MME e publicados pelo jornal Folha de São Paulo em 07/01/2009. 
Destaque-se que com a decisão da Comissão Interministerial da Mudança Global do Clima (CIMGC) de calcular o fator de emissão do SIN pelo método da análise dos dados do despacho (método $c$ do Tool to calculate the emission factor for an electricity system), todos os projetos candidatos ao MDL conectados ao SIN deverão adotar esse fator como linha de base, a menos que apresentem uma nova metodologia e que ela seja aprovada pelo Comitê Executivo (CE) do Mecanismo de Desenvolvimento Limpo (MDL).

Como de acordo com essa ferramenta, o fator de emissão deverá ser atualizado anualmente durante o monitoramento, nenhum novo projeto poderá prescindir de uma visão futura, em termos quantitativos e qualitativos, sobre o comportamento do fator de emissão do SIN, para que possa avaliar, realisticamente, os fluxos de receitas associados às atividades do projeto candidato ao MDL.

Concretamente, como o fator de emissão apurado no SIN, em 2007, é baixo ${ }^{78}$, de 0,18 $\mathrm{tCO}_{2} / \mathrm{MWh}$, se um potencial proponente de um projeto de MDL considerar que no futuro a quantidade de emissões por unidade de energia permanecerá próxima ao que está sendo apurado com base na análise dos dados do despacho, então o MDL não cumprirá o seu papel de remunerar a adicionalidade do projeto candidato ao MDL, desestimulando a implementação desse projeto.

Se, por outro lado, esse proponente considerar que haverá uma elevação desse fator de emissão, dois cenários poderão ser desenhados: o primeiro, que de fato ocorra tal elevação, em valor próximo ao que foi considerado pelo proponente do projeto. Então o proponente realiza os ganhos esperados e o MDL cumpriu o seu papel de remunerar a adicionalidade do projeto.

O segundo cenário é que tais previsões de elevação do fator de emissão não ocorram, ou ocorram abaixo do que foi considerado pelo proponente como mínimo necessário para remunerar a adicionalidade do projeto. Neste caso, pelo

\footnotetext{
78 - Ressalte-se que, até o presente momento, quase nenhum projeto de MDL conectado ao SIN adotou fator de emissão inferior a $0,25 \mathrm{t} \mathrm{CO}_{2} / \mathrm{MWh}$. Até março de 2008 todos os projetos que haviam sido aprovados na CIMGC ainda puderam se beneficiar da opção ex-ante para a validação dos dados, cuja adoção permitia o não monitoramento do fator de emissão adotado durante dez ou sete anos, conforme a definição do proponente para o período de obtenção de crédito.
} 
menos teoricamente, o projeto poderá perder a sua sustentabilidade, o que ameaça a continuidade das suas atividades de redução das emissões dos GEE.

É nesse contexto de incertezas quanto ao comportamento futuro das emissões dos GEE do SIN e no impacto que a avaliação das emissões associadas à linha de base de um projeto candidato ao MDL produz sobre a decisão de realizar ou não um determinado investimento, que surge a necessidade de que novos métodos de cálculo do fator de emissão do SIN sejam desenvolvidos e aprimorados.

Não é demasiado reafirmar as dificuldades e a complexidade que envolve fazer previsões e cenários sobre as condições operativas futuras do SIN. Com efeito, trata-se do maior sistema hidrotérmico, predominantemente hídrico, interligado do mundo, em si fonte de alto grau de incertezas quanto à energia assegurada em ciclos futuros.

Além disso, a situação é agravada pelo momento de mudanças no perfil da sua matriz que, apesar de ainda não ter se completado, aponta para uma crescente fossilização, seja considerando a oferta de energia nova para os próximos 3 e 5 anos, com base nos resultados dos leilões de energia realizados, seja pelo fato de que são crescentes as dificuldades para a implementação de novos e grandes empreendimentos hidrelétricos, sobretudo na região Norte do país onde se concentram os maiores potencias hídricos, seja ainda considerando as perspectivas de expansão do parque gerador (PDEE 2008-2017) que prevê um grande aumento na instalação de UTE movidas a combustíveis fósseis.

O desenvolvimento de um projeto candidato ao MDL a ser conectado ao SIN, qualquer que seja a metodologia aplicada e/ou desenvolvida para quantificar a linha de base, se defrontará com a necessidade de estimar o comportamento futuro das emissões dos GEE, na medida em que não será mais possível escolher a opção ex-ante para a validação da linha de base. 
Nesse Capítulo são apresentados o conceito, as premissas e o método de cálculo para estimar a linha de base (LB) de um projeto candidato ao MDL a ser implantado em sistema elétrico hidrotérmico, predominantemente hídrico.

\subsection{Conceito/aplicabilidade}

Esta metodologia estima as emissões do sistema elétrico, medidas em $\mathrm{tCO}_{2} / \mathrm{ano}$, e o fator de substituição, em $\mathrm{tCO}_{2} / \mathrm{MWh}$, de projetos candidatos ao $\mathrm{MDL}$ conectados à rede elétrica, a partir do mix da energia atual fornecida pelas usinas que geram energia elétrica para o sistema ${ }^{79}$ e pelo mix futuro das usinas que fornecerão eletricidade à rede elétrica interligada.

O mix futuro é determinado pelos empreendimentos que compõem o planejamento da expansão do sistema elétrico interligado, incluindo a oferta de energia nova resultante dos leilões $A 3$ e $A 5^{80}$ realizados pelo setor elétrico e o Termo de Compromisso da Petrobrás relativo ao fornecimento de gás natural às UTE movidas a esse combustível.

Aplica-se às atividades de projetos elegíveis MDL que utilizam fontes renováveis de energia e/ou atividades de projetos que reduzem eletricidade que de outra forma seria fornecida pelo sistema elétrico interligado, a exemplo da implementação de programas/medidas de eficiência energética pelo lado da demanda.

Os projetos elegíveis são aqueles que comprovem que:

\footnotetext{
79 - A configuração completa em dezembro de 2007 do parque gerador do SIN encontra-se nos Apêndices B, C.1, C.2, C.3 e C.4 desse trabalho.

80 - Idem. O resumo da energia transacionada nos leilões de energia nova por fonte de recurso encontra-se na Tabela 1 do Capítulo 1 de Introdução.
} 
1) São adicionais, conforme estabelece o Tool for demonstration and assessment of additionality ${ }^{81}$;

2) As usinas geradoras de energia elétrica são movidas a fontes renováveis não emissoras dos $\mathrm{GEE}^{82}$, exceto para as usinas nucleares;

3) A energia fornecida é despachada na base por meio de uma usina movida a fonte renovável não emissora e/ou a energia economizada por programas/medidas de eficiência energética reduz a demanda em igual valor ao que foi poupado com a entrada de um projeto de eficientização de MDL.

O cálculo das emissões evitadas, por meio de um projeto específico candidato ao MDL é feito por diferença entre as emissões dos GEE associadas à configuração inicial ou de base, dada pelo mix das usinas existentes e planejadas, servindo ao sistema elétrico, no horizonte do estudo e a configuração final, caracterizada pelo deslocamento de parte da geração das usinas existentes, pela entrada de uma quantidade de energia limpa, não emissora dos GEE ou pela redução da demanda agregada do sistema elétrico pela implementação de programas/medidas de eficiência energética, em substituição à mesma quantidade de energia gerada a partir do mix inicial da oferta do sistema elétrico ao qual o projeto foi conectado.

As emissões evitadas são expressas, em termos relativos, pelo Fator de Substituição do Sistema Elétrico ( $F S_{S E}$ ) definido pela variação das emissões associadas à configuração inicial ou de base $\left(\mathrm{ET}_{\mathrm{SEb}}\right)$ e as emissões totais associadas à configuração final ( $\left.\mathrm{ET}_{\mathrm{SE}}\right)$ dividida pela eletricidade deslocada na rede elétrica pela energia fornecida/economizada com a entrada de uma quantidade de energia não emissora dos GEE. O FS $S_{S E}$ é calculado em termos anuais $\left(F_{S E y}\right)$ e para todo o período de obtenção de créditos $\left(F S_{S E p}\right)$.

\footnotetext{
81 - Tool for demonstration and assessment of additionality, versão 5, aprovada na 39a. Reunião do Conselho Executivo do MDL, em 16 de maio de 2008.

82 - Fontes de energia renovável consideradas: $\mathrm{PCH}$, eólica, solar, geotérmica, marés e biomassas.
} 
Esta metodologia fornece os procedimentos para calcular os seguintes parâmetros:

Tabela 13 - Parâmetros utilizados na metodologia

\begin{tabular}{ccc}
\hline Parâmetro & Unidade & Descrição \\
\hline $\mathrm{ET}_{\mathrm{SEb}}$ & $\mathrm{tCO}_{2 \mathrm{SEb}} / \mathrm{ano}$ & $\begin{array}{c}\text { Emissões totais anuais do sistema elétrico da configuração inicial ou } \\
\text { de base }\end{array}$ \\
$\mathrm{FE}_{\mathrm{SEb}}$ & $\mathrm{tCO}_{2 \mathrm{SEb}} / \mathrm{MWh}$ & Fator de emissão do sistema elétrico da configuração inicial ou de \\
base
\end{tabular}

\subsection{Procedimentos para estimar a linha de base (LB) de sistema elétrico interligado e calcular o Fator de Substituição do projeto MDL}

Identificação do sistema elétrico/da configuração de base/ das emissões associadas

\section{Passo a passo:}

1. Identificar o sistema elétrico no qual as atividades do projeto MDL serão implementadas e definir o período de obtenção de crédito para o qual se pretende determinar as emissões deslocadas com o projeto;

2. Definir a configuração de base ou inicial do sistema elétrico e determinar a energia gerada (MWh) na configuração inicial, em nível horário, mensal ou 
anual $^{83}$, com a aplicação de um modelo de previsão de despacho das usinas, por meio da simulação do equilíbrio entre oferta e procura por energia elétrica ${ }^{84}$;

3. Calcular as emissões totais $\left(E T_{S E b}\right.$ ) e o fator de emissão ( $F E_{S E b}$ ) associados ao despacho das usinas térmicas na configuração inicial ou de base.

Estimativa da linha de base do projeto ( $\left.F S_{S E}\right)$ : energia efetivamente deslocada com as atividades de um projeto candidato ao $M D L$

4. Re-simular o equilíbrio entre oferta e demanda por energia elétrica e calcular a energia gerada (MWh), em nível horário, mensal ou anual em função da entrada na base do sistema elétrico de uma usina não emissora ${ }^{85}$ dos GEE ou da redução da demanda agregada por energia em valor equivalente à economia de eletricidade esperada pela aplicação de programas/medidas de eficiência energética;

5. Calcular as emissões totais associadas à nova configuração ou final $\left(\mathrm{ET}_{\mathrm{SEF}}\right)$;

6. Calcular o fator de substituição das emissões anuais $\left(F_{S E y}\right)$ e para todo $o$ período de obtenção de créditos ( $\mathrm{FS}_{\mathrm{SEp}}$ );

7. Determinar as estatísticas relevantes dos fatores de substituição calculados, a exemplo da mediana, média, $1^{\circ}$ e $3^{\circ}$ quartis, máximo e mínimo;

8. Calcular o fator de substituição descontado (FS SED/MWh $_{\text {nara }}$ pavaliar o risco associado ao ( $\mathrm{FS}_{\mathrm{SEp}} / \mathrm{MWh}$ ) (opcional).

\footnotetext{
83 - A depender do nível de desagregação permitido pelo modelo de equilíbrio utilizado.

${ }^{84}$ - Há vários modelos desenvolvidos para simular a operação futura de sistemas hidrotérmicos. No Sistema Interligado Nacional (SIN) o Operador Nacional do Sistema (ONS) usa o modelo Newave. Mais detalhes sobre o NEWAVE encontram-se no Manual do Newave (CEPEL, 2006) No presente trabalho as simulações foram feitas com base no modelo MEI de equilíbrio geral apresentado no Capítulo 4. O modelo MEI prevê a política operativa do SIN, com foco na segurança energética, utilizando um modelo computacional baseado em programação dinâmica estocástica.

85 - Excluindo usinas nucleares pelas restrições existentes no âmbito do MDL.
} 
Desenvolvimento do passo a passo:

1. Identificação do sistema elétrico do projeto candidato ao MDL

Adotam-se nessa proposta metodológica as mesmas definições de sistema elétrico do projeto e do sistema elétrico conectado definido no Tool to calculate the emission factor for an electricity system, versão 1 (Report EB35, Annex 12, 2008).

Assim, o sistema elétrico do projeto é definido pelo conjunto de usinas que geram energia elétrica e que podem ser despachadas sem restrições significativas de transmissão. Similarmente, o sistema elétrico conectado é definido como um sistema elétrico interligado por linhas de transmissão ao sistema elétrico do projeto, dentro do qual as usinas podem ser despachadas sem restrições significativas de transmissão (EB35, Anexo 12, 2008).

A existência ou não de restrições entre sistemas elétricos interligados, bem como os intercâmbios entre os sistemas (exportações e importações de energia elétrica) podem ser considerados internamente no modelo de simulação adotado. Caso o modelo não faça isso, então se faz necessário estabelecer procedimentos adicionais para simular as restrições de transmissão e os intercâmbios entre os sistemas elétricos interligados.

2. Definição da configuração de base e determinação da energia gerada (MWh) na configuração de base

A configuração de base é definida pela atual capacidade instalada no sistema elétrico e pelos empreendimentos planejados para entrarem em operação durante o período de obtenção de créditos considerado, incluindo a oferta de 
energia nova das usinas vencedoras dos leilões A3 e A5 realizados pelo setor elétrico nacional.

O despacho hidrotérmico do sistema elétrico onde se localizam as atividades do projeto candidato ao MDL é determinado com a aplicação de um modelo que utiliza técnicas de simulação para indicar todas as possíveis soluções de equilíbrio entre a oferta e demanda por energia elétrica.

No modelo MEI são geradas 2000 séries estocásticas, a partir da série histórica de ENA, que representam 2000 possíveis e equiprováveis trajetórias de ENA projetadas. Para cada série, o modelo simula um provável despacho hidrotérmico que minimiza o custo total da geração.

O despacho hidrotérmico também poderá ser determinado usando outro procedimento, desde que os dados, suposições e circunstâncias sejam claramente definidas e mensuráveis.

O despacho das usinas é feito primeiramente para a configuração de base, conforme descrita no passo 2 e depois é repetido para a nova configuração, descrita no passo 4.

Se for aplicado um modelo de simulação, para cada solução de equilíbrio encontrada - $n$ séries - há um conjunto $m$ de usinas térmicas convencionais flexíveis que se supõe sejam despachadas por ordem de mérito para atenderem as necessidades de complementação energética do sistema.

Os próximos passos visam identificar as emissões dos GEE associadas a esse conjunto de usinas e, na seqüência, medir como as emissões dessas usinas são deslocadas com a entrada de quantidades de energias ofertadas por usinas não emissoras ou pela redução da demanda agregada em conseqüência da implementação de programas/medidas de eficiência energética pelo lado da demanda. 
3. Cálculo da Linha de Base (LB) do sistema elétrico interligado: Emissões Totais $\left(E T_{S E b}\right)$ e o Fator de Emissão ( $F E_{S E b}$ ) na configuração de base

Cálculo das Emissões Totais no período de obtenção de créditos - ET SEb

As emissões são calculadas para todos os conjuntos $m$ de usinas térmicas flexíveis despachadas, na configuração de base e final, não incluindo as usinas hidrelétricas e termelétricas despachadas na base.

As emissões podem ser calculadas com base nos seguintes dados:

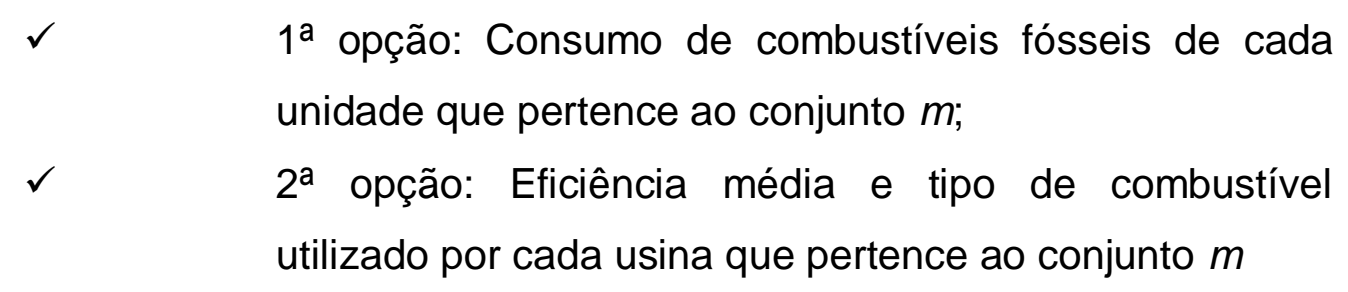

Se a $1^{\text {a }}$ opção for escolhida, então ET SEb é calculada como segue:

$E T_{S E b}=\sum_{i, u, y} \mathrm{TC}_{\text {iuy }} \times \mathrm{NVC}_{\mathrm{iy}} \times \mathrm{FE}_{\mathrm{CO}_{2} i y}$, onde:

$E T_{\text {SEb }}=$ total de emissões associadas aos conjuntos $m$ identificados para cada solução de equilíbrio da configuração de base

$\mathrm{TC}_{\text {iuy }}=$ montante do combustível fóssil do tipo $i$ usado na usina $u$ no ano $y$ (unidade de massa ou volume)

$N V C_{i y}=$ poder calorífico líquido do combustível fóssil do tipo $i$ no ano $y$ (GJ/unidade de massa ou volume)

$\mathrm{FE}_{\text {CO2iy }}=$ fator de emissão do combustível fóssil do tipo $i$ no ano $y$ $\left(\mathrm{tCO}_{2} / \mathrm{GJ}\right)$.

$\mathrm{i}$ = tipo de combustível fóssil queimado na usina $u$ no ano $y$

$u=$ todas as usinas que pertencem aos conjuntos $m$ da configuração de base

$y=$ cada ano do período definido para obtenção de créditos de carbono. 
Os $\mathrm{FE}_{\mathrm{CO} 2}$ para os diferentes combustíveis encontram-se na Tabela 16 apresentada no item 5.5 do presente Capítulo. O poder calorífico (NVC) por tipo de combustível se encontra na Tabela E.9 do Balanço Energético Nacional (2007).

Se a 2ª opção for a escolhida, então ET SEb é calculada como segue:

$E T_{S E b}=\sum_{u, y} G_{u y} \times F E_{u y}$, onde:

$\mathrm{ET}_{\mathrm{SEb}}=$ Total de emissões associadas aos conjuntos $m$ identificados para cada solução de equilíbrio da configuração de base

$\mathrm{G}_{\mathrm{uy}}=$ Energia gerada e distribuída à rede pela usina $u$ no ano $y$ (MWh)

$\mathrm{FE}_{\mathrm{uy}}=$ Fator de Emissão da unidade geradora $u$ no ano $y\left(\mathrm{tCO}_{2} / \mathrm{MWh}\right)$

Sendo,

$\mathrm{FE}_{\text {uy }}=\frac{\mathrm{FE}_{\mathrm{CO}_{2} \text { iuy }} \times 3,6}{\eta_{\text {uy }}}$, onde:

$\mathrm{FE}_{\mathrm{uy}}=$ Fator de Emissão da unidade geradora $u$ no ano $y\left(\mathrm{t}_{\mathrm{co} 2} / \mathrm{MWh}\right)$

$\mathrm{FE}_{\mathrm{CO} \text { iuy }}=$ Fator de emissão médio do tipo de combustível $i$ usado na usina $u$ no ano y $\left(\mathrm{tCO}_{2} / \mathrm{GJ}\right)$

$\eta_{\text {uy }}=$ Eficiência média de conversão da usina u no ano $y(\%)$

$1 \mathrm{MWh}=3,6 \mathrm{GJ}$

$\mathrm{i}$ = tipo de combustível fóssil queimado na usina $u$ no ano $y$

$u=$ usinas que pertencem aos conjuntos $m$ da configuração de base

y = cada ano do período definido para obtenção de créditos de carbono 
Encontra-se no item 5.5 do presente Capítulo na Tabela 13, o procedimento adotado para determinar o $\mathrm{FE}_{\text {coziuy }}$ de acordo com o IPCC (1996) - Revised Guidelines for National Greenhouse Gas Inventories, vol.2.

\section{Cálculo do Fator de Emissão de Sistema Elétrico Interligado - FE}

O cálculo do fator de emissão da configuração de base leva em consideração apenas as usinas térmicas flexíveis. Assim para determinar esse fator, toma-se 0 total de emissões estimadas em cada ano do período e divide-se pelo total de energia gerada por estas usinas, a cada ano, no mesmo período.

Como não se leva em consideração o preço de despacho, este fator não deve ser tomado diretamente como o fator de substituição associado a um projeto elegível como MDL, mas apenas como um indicador do nível de emissões médios do sistema em se tratando das usinas substituíveis.

$F E E_{b}=\frac{E T_{S E b}}{G T_{S E b}}$, onde:

$\mathrm{FE}_{\mathrm{SEb}}=$ Fator de emissão da configuração de base.

$\mathrm{ET}_{\mathrm{SEb}}=$ Total de emissões associadas aos conjuntos $m$ identificados para cada solução de equilíbrio da configuração de base

$\mathrm{GT}_{\text {SEb }}=$ Geração total das usinas flexíveis que serve ao sistema elétrico, sendo:

$G T_{S E b}=\sum_{u, y} G_{u y}$, onde:

$\mathrm{u}=$ todas as usinas que pertencem aos conjuntos $m$ da configuração de base $y=$ cada ano do período definido para obtenção de créditos de carbono. 
4. Re-simular o equilíbrio entre oferta e demanda por energia elétrica pela entrada do projeto MDL e determinar a energia gerada (MWh), em nível horário, mensal ou anual.

4.1 - Define-se a energia que será deslocada com a entrada no sistema elétrico de uma usina não emissora ${ }^{86}$ dos GEE na base ou da redução da demanda agregada por energia em valor equivalente a economia de eletricidade esperada pela aplicação de programas/medidas de eficiência energética pelo lado da demanda.

4.2 - Aplica-se o modelo para simular a nova configuração ou configuração final de despacho das usinas térmicas flexíveis, obtendo-se 2000 novas soluções de equilíbrio entre a oferta e demanda de energia elétrica.

5. Calcular as emissões totais associadas à nova configuração ou final (ET SEf lano)

Uma vez determinadas as energias associadas à configuração final repete-se o procedimento descrito no item 3 acima descrito para calcular as emissões totais da configuração final.

6. Cálculo do Fator de Substituição do Sistema Elétrico: (FS SEy $_{\text {) }}$ anual e (FS para o período de obtenção de crédito de carbono definido

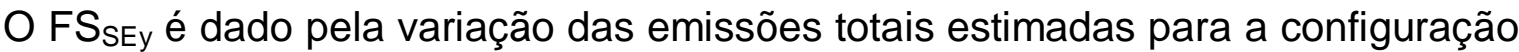
de base e a configuração final dividida pela quantidade de energia elétrica (MWh)

${ }^{86}$ - Não é considerado o despacho de usinas nucleares pelas restrições no âmbito do MDL 
gerada ou reduzida pelas atividades do projeto mitigador dos GEE. É calculado como segue:

$\mathrm{FS}_{\mathrm{SEy}}=\frac{\left(\mathrm{ET}_{\mathrm{SEby}}-\mathrm{ET}_{\mathrm{SEFy}}\right)}{\mathrm{G}_{\mathrm{ATy}}}$, onde:

$\mathrm{FS}_{\mathrm{SEy}}=$ Fator de substituição do sistema elétrico no ano y $\left(\mathrm{tCO}_{2} / \mathrm{MWh}\right)$

$\mathrm{ET}_{\text {SEby }}=$ total anual de emissões associadas em cada ano $y$ aos conjuntos $m$ identificados para cada solução de equilíbrio da configuração de base $\left(\mathrm{tCO}_{2}\right)$

$\mathrm{ET}_{\mathrm{SEfy}}=$ total anual de emissões associadas em cada ano $y$ aos conjuntos $m$ identificados para cada solução de equilíbrio da configuração final $\left(\mathrm{tCO}_{2}\right)$

$\mathrm{G}_{\text {ATy }}=$ quantidade de energia elétrica gerada ou reduzida pelas atividades do projeto mitigador dos GEE em cada ano $y$ (MWh).

O FS $S_{\text {SEp }}$ é dado pela média dos fatores de substituição anuais ( $\left.F S_{S E y}\right)$. Assim,

$\mathrm{FS}_{\mathrm{SEP}}=\frac{\sum_{\mathrm{y}}\left(\mathrm{FS}_{\mathrm{SEy}}\right)}{\mathrm{N}_{\mathrm{LBP}}}$, onde:

$\mathrm{FS}_{\mathrm{SEp}}=$ Fator de Substituição do sistema elétrico para todo o período de obtenção de créditos ( $\mathrm{tCO}_{2} / \mathrm{MWh}$ )

$\mathrm{FE}_{\mathrm{SEy}}=$ Fator de Substituição do sistema elétrico para o ano y $\left(\mathrm{tCO}_{2} / \mathrm{MWh}\right)$ $\mathrm{N}_{\mathrm{LBP}}=$ Número de anos de obtenção de créditos do projeto.

7. Determinação das estatísticas relevantes das $n$ séries de $F S_{\text {SEy }}$ e $F S_{\text {SEp }}$ : mediana, média, $1^{\circ}$ e $3^{\circ}$ quartis, percentis 5 e 95, máximo e mínimo 
A partir dos 2000 igualmente prováveis resultados correspondentes a todas as soluções de equilíbrio simuladas pelo modelo é feita a distribuição de probabilidades e identificadas às estatísticas consideradas relevantes.

Como cada série de despacho é função de uma série específica de ENA, tanto para a configuração de base como para a configuração final, calcula-se, primeiramente, a diferença das emissões totais entre as duas configurações para em seguida distribuir os resultados dos fatores de substituição encontrados tanto para os $\mathrm{FS}_{\text {SEy }}$ como para o $\mathrm{FS}_{\text {SEP }}$.

8. Cálculo do Fator de Substituição Descontado (FS SED) (opcional)

Calcula-se o $\mathrm{FS}_{\mathrm{SED}}$, aplicando-se uma taxa de desconto à série anual dos fatores de substituição. A taxa de desconto deverá ser definida pelo proponente do projeto em função da sua percepção de risco do projeto. Quanto maior a incerteza (ou percepção de risco) sobre como será o cenário futuro maior deverá ser o desconto e vice-versa.

Portanto, não há como assumir, a priori, um fator de desconto. Essa definição dependerá de muitos fatores como: o grau de confiança em relação aos resultados encontrados, à disponibilidade de dados e informações existentes sobre o comportamento da demanda por energia elétrica, sobre as políticas operativas do sistema elétrico, sobre a estabilidade do marco regulatório setorial, disponibilidade de capitais para investimentos no setor de geração de eletricidade, apenas para citar algumas que mais diretamente afetam o planejamento da expansão do sistema elétrico.

O FE $E_{S E D}$ é calculado como se segue: 
$\mathrm{FS}_{\mathrm{SED}}=\sum_{\mathrm{y}}\left[\frac{\mathrm{FE}_{\text {SEy }}}{(1+\mathrm{i})^{y}}\right]$, onde:

$\mathrm{FS}_{\mathrm{SED}}=$ Fator de substituição descontado para o período de obtenção de créditos $\left(\mathrm{tCO}_{2} / \mathrm{MWh}\right)$

$\mathrm{FS}_{\mathrm{SEy}}=$ Fator de substituição para cada ano $y$ durante o período de obtenção de créditos ( $\mathrm{tCO}_{2} / \mathrm{MWh}$ )

$y=$ quantidade de anos a partir do ano de base.

No presente trabalho sugere-se que os seguintes critérios sejam adotados preliminarmente, para avaliar o grau de risco associado ao fator de substituição encontrado:

Se o $\mathrm{FS}_{\mathrm{SED}}$ é menor que o fator de emissão mais recentemente publicado pela AND, então o valor calculado para o fator de substituição ( $F S_{\mathrm{SE}}$ ) deve ser considerado de baixo risco;

- Se o $\mathrm{FS}_{\mathrm{SED}}$ é maior que o fator de emissão mais recentemente publicado pela AND, então o valor calculado para o fator de substituição ( $\left(\mathrm{SS}_{\mathrm{SE}}\right)$ deve ser visto com reserva, sendo aconselhável o desenvolvimento de novos cenários e análises mais detalhadas e qualitativas sobre a participação das fontes fósseis na futura matriz do setor elétrico nacional.

\subsection{Cálculo do Fator de Substituição do período de obtenção de crédito $\left(\mathrm{FS}_{\mathrm{SEp}}\right)$ e do Fator de Substituição anual $\left(\mathrm{FS}_{\mathrm{SEy}}\right)$}

Conforme anteriormente mencionado, para determinar as emissões deslocadas pela entrada no sistema elétrico de um projeto que reduz emissões dos GEE, o fator de substituição das emissões é medido, considerando a mesma série de emissões, chamada de base, composta de 10 anos, cada ano com um valor de 
emissão total de $\mathrm{CO}_{2}$; em seguida, mede-se quanto serão as emissões do sistema elétrico, em cada ano (y), com a entrada do projeto desde o primeiro ano.

O cálculo do fator de substituição começa pela diferença, ano a ano, da série calculada com o projeto, subtraída da série base. Este resultado é então dividido pelo número de MWh gerados pelo projeto no ano específico. As equações 6 e 7 , acima descritas são usadas para calcular esses fatores de substituição.

Uma discussão relevante e que deve ser levantada é a seguinte: o projeto de MDL deve ou não ser considerado na configuração de base após ser implementado? Antes de responder a essa questão é importante revisar o que o $\mathrm{CE}$ do MDL coloca e como tenta resolver esse problema.

De acordo com a Tool to calculate the emission factor for an electricity system, unidades geradoras registradas como MDL devem ser incluídas para calcular o fator de emissão da margem combinada do sistema elétrico se o critério de inclusão se aplica ao grupo de usinas que comporão a margem operacional e a margem de construção.

Para calcular o fator de emissão da margem operacional é considerado o grupo composto pelas usinas que formam o topo do despacho, a cada hora. Esse grupo de usinas deve representar um percentual do total da eletricidade despachada a cada hora, onde esse percentual deve igual ou maior entre: $10 \%$ da energia total despachada na hora, ou a quantidade de eletricidade deslocada pelo projeto de MDL durante a hora dividida pelo total da eletricidade gerada pela rede durante essa mesma hora.

Para calcular o fator da margem de construção a orientação geral é que projetos registrados como MDL devem ser excluídos do grupo de usinas que serão consideradas para calcular esse parâmetro. Entretanto, faz a seguinte ressalva: se no grupo de usinas identificadas para estimar a margem de construção aparecer usinas construídas há mais de 10 anos, então estas devem ser excluídas do grupo e devem ser incluídos os projetos registrados como MDL, que são despachados compulsoriamente pelo operador do sistema elétrico. 
Observe-se que a exclusão ou inclusão dos projetos registrados como MDL no grupo de usinas considerado para calcular os dois fatores (margem operacional e margem de construção) depende do enquadramento ou não desses projetos nos critérios acima mencionados.

Portanto, a não ser em sistemas elétricos de países ou regiões onde o crescimento do mercado seja muito pequeno, dificilmente um projeto registrado de MDL comporá o grupo de usinas da margem de construção.

Do mesmo modo, é muito improvável que projetos de energias renováveis não convencionais componham o topo das usinas que formam a margem operacional. Em geral, pela natureza das tecnologias associadas a essas fontes energéticas que substituem combustíveis fósseis o despacho é feito na base.

Os critérios também não se aplicam para projetos de MDL de eficiência energética pelo lado da demanda, na medida em que eles reduzem a demanda agregada. Não fazem parte, portanto, das usinas que compõem o topo do despacho, nem das usinas recentemente construídas.

Além disso, e talvez o mais importante, a adoção de uma base móvel, ou seja, incorporar ao ano anterior a geração do projeto limpo vai de encontro ao conceito da linha de base, que é definida com base na hipótese das emissões que ocorreriam na ausência das atividades do projeto de MDL.

Portanto, sendo a linha de base apenas uma hipótese, na medida em que a existência do projeto de MDL a torna impossível de ser comprovada, para que seja possível verificar as reduções de emissões decorrentes das atividades do projeto de MDL é necessário supor a existência dela sem o referido projeto. Admitir essa hipótese é a única forma de, efetivamente, mensurar as emissões reduzidas pela ação do projeto candidato ao MDL.

Esse procedimento se justifica porque só deste modo será possível captar e remunerar as externalidades positivas geradas por um projeto candidato ao 
$\mathrm{MDL}^{87}$, por exemplo, em economia de água de reservatórios e, conseqüentemente, maior disponibilidade de geração hidrelétrica, ainda que o direito de propriedade desta externalidade não esteja esclarecido.

Ressalte-se, finalmente, que a CIMGC exclui para calcular o fator de emissão do SIN os projetos registrados como MDL (MCT, 2007).

\subsection{Procedimento de cálculo do fator de emissão dos combustíveis fósseis para a geração de eletricidade}

O fator de emissão da geração de eletricidade, medido em $\mathrm{tCO}_{2} / \mathrm{MWh}$, é calculado com base no fator de emissão dos combustíveis fósseis apresentados na Tabela 1-2 do Revised Guidelines for National Greenhouse Gas Inventories, vol.2. Ele expressa a quantidade de dióxido de carbono contido em cada tipo de combustível fóssil que é liberada pela queima desses combustíveis na geração de eletricidade.

Para calcular o fator de emissão em $\mathrm{tCO}_{2} / \mathrm{MWh}$ considerou-se:

1 - O fator de emissão do combustível fóssil determinado na Tabela 1-2 do Revised Guidelines for National Greenhouse Gas Inventories, vol.2, em TC/TJ;

2 - A relação de $1 \mathrm{MWh}=3,6 \mathrm{GJ}$;

3 - A transformação do carbono $(\mathrm{C})$ em dióxido de carbono $\left(\mathrm{CO}_{2}\right)$ aplicando o fator 44/12, ou seja, dado que a massa atômica do carbono é 12 e do oxigênio 16, então a massa atômica do $\mathrm{CO}_{2}$ é 44. Para transformar $\mathrm{C}$ em $\mathrm{CO}_{2}$ a relação é de 44/12.

\footnotetext{
87 - A exemplo de projetos de geração de eletricidade com fontes renováveis, eólica, solar,
} biomassa, etc e/ou projetos de eficiência energética pelo lado da demanda para o SIN. 
$\mathrm{Na}$ Tabela 14 são apresentados exemplos da aplicação do procedimento para calcular os fatores de emissão por unidade de energia elétrica gerada, para eficiência de $100 \%$ da transformação do calor em eletricidade.

Tabela 14 - Fator de Emissão para geração de eletricidade

\begin{tabular}{|c|c|c|c|c|c|c|c|}
\hline Combustível & Unidade & $\begin{array}{c}\text { Conteúdo } \\
\text { de energia } \\
\text { por } \\
\text { combustível } \\
\text { (TJ/unidade) }\end{array}$ & $\begin{array}{c}\text { Fator de } \\
\text { emissão de } \\
\text { carbono por } \\
\text { combustível } \\
\text { (tC/TJ) }\end{array}$ & $\begin{array}{c}\text { Fator } \\
\text { de } \\
\text { oxidação }\end{array}$ & $\begin{array}{l}\text { Emissão } \\
\text { (tCO } \mathrm{tCO}_{2} \text { unid) }\end{array}$ & $\begin{array}{c}\text { Conversão } \\
\text { para } \\
\text { MWh } \\
\text { (tC/KWh) }\end{array}$ & $\begin{array}{c}\text { Conversão } \\
\text { para } \\
\mathrm{MWh} \\
(\mathrm{tCO} / \mathrm{KWh})\end{array}$ \\
\hline Óleo Diesel & $1000 \mathrm{~m}^{3}$ & 35,52 & 20,2 & 0,99 & 2604,54 & 72,72 & 266,64 \\
\hline Óleo Comb. & $10^{6} \mid$ & 40,15 & 21,1 & 0,99 & 3075,21 & 75,96 & 278,52 \\
\hline $\begin{array}{l}\text { Carvão } \\
\text { Vapor }\end{array}$ & $1000 t$ & 11,93 & 26,2 & 0,98 & 1106,01 & 94,32 & 345,84 \\
\hline $\begin{array}{c}\text { Gás Nat. } \\
\text { Seco }\end{array}$ & $10^{6} \mathrm{~m}^{3}$ & 36,84 & 15,3 & 0,995 & 2056,39 & 55,08 & 201,96 \\
\hline
\end{tabular}

Como na realidade as eficiências são sempre menores que 100\% divide-se o fator calculado, $\mathrm{tCO}_{2} / \mathrm{MWh}$, pela eficiência da unidade geradora. Por exemplo, se a eficiência da unidade geradora que queima óleo diesel para gerar eletricidade é de $50 \%$, então:

$267 / 0,50=534 \mathrm{KgCO}_{2} / \mathrm{MWh}$. 


\section{Capítulo 6 Aplicação da metodologia proposta para estimar o Fator de Substituição para projeto de MDL conectado ao SIN}

\subsection{Aspectos Introdutórios}

Nesse Capítulo aplica-se a metodologia proposta no Capítulo 5, para estimar as emissões futuras do $\mathrm{SIN}$ ( $\mathrm{ET}_{\mathrm{SIN}}$ ), em $\mathrm{tCO}_{2} /$ ano e $\mathrm{tCO}_{2} / \mathrm{MWh}$, e calcular os fatores de substituição associados a entrada na base do sistema interligado de gerações provenientes de usinas movidas à fontes renováveis de energia elétrica e/ou pela redução da demanda agregada do SIN, em valor equivalente a economia de eletricidade esperada pela aplicação de programas/medidas de eficiência energética.

Para tanto, foram realizados 12 experimentos. Cada experimento consiste em introduzir uma quantidade de energia limpa, decorrentes de projetos de MDL, em MW médios, a partir de um cenário de base do MEI, para verificar as alterações das emissões associadas e obter os fatores de substituição correspondentes.

Para agrupar os experimentos, foram criados cenários que consideram ou não a entrada de parte do programa de eficiência energética anunciado no PDEE 20072016 (MME, 2007). Dentro de cada grupo, projetos de diferentes capacidades foram introduzidos, e os fatores de substituição obtidos foram comparados.

Um grupo adicional de experimentos foi realizado considerando apenas a entrada, com diferentes tamanhos, do programa de eficiência. A descrição dos experimentos encontra-se no item 6.3 do presente capítulo.

Supõe-se que as atividades dos projetos acima mencionados sejam elegíveis como MDL, ou seja, eles substituirão parcialmente a eletricidade que de outra forma seria gerada pelo mix das gerações das usinas existentes e planejadas, que fornecerão eletricidade ao SIN para atendimento ao mercado durante o 
período de obtenção de créditos de carbono de 10 anos, considerados nessa aplicação.

Destaca-se que a presente proposta metodológica trata apenas de estimar o fator de emissão do sistema interligado de um projeto candidato ao MDL conectado ao SIN. Esse ponto é importante porque até outubro de 2007, quando o Comitê Executivo (CE) do MDL aprovou e publicou a primeira versão do Tool to calculate the emissions factor for an electrical system, a metodologia de cálculo do fator de emissão do sistema elétrico era parte integrante da metodologia ACM $0002^{88}$. Projetos de diferentes escopos recorriam à metodologia ACM 0002 para calcular esse fator, o que na prática significava usar duas metodologias para um mesmo projeto.

Com a aprovação pelo CE do MDL dessa ferramenta metodológica, se o projeto for conectado a um sistema interligado e, supostamente, deslocar emissões do sistema elétrico interligado, o fator de emissão do sistema elétrico é calculado separadamente e independe das metodologias associadas aos seus respectivos escopos e da aplicação da ferramenta para determinar a adicionalidade do projeto.

\subsection{Aplicação da metodologia para o SIN}

\subsubsection{Identificação do sistema elétrico do projeto}

De acordo com a Resolução ㄲo. 8 da CIMGC $^{89}$, de 26 de maio de 2008, considerando os critérios sugeridos no Tool to calculate the emissions factor for an electrical system, que definem a existência ou não de restrições significativas de transmissão, o SIN foi considerado, para efeito de projetos candidatos ao MDL, como sistema único, ou seja, todas as usinas que servem ao SIN podem

\footnotetext{
88 - ACM 002 - Consolidated baseline methodology for grid connected generation from renewable sources, version 7.

89 - A CIMGC no Brasil é a Autoridade Nacional Designada (AND) criada pelo Decreto de 7 de julho de 1999.
} 
ser despachadas em qualquer ponto do sistema elétrico sem restrições de transmissão ${ }^{90}$.

A decisão da CIMGC baseou-se ainda no fato de que a ampliação dos reforços de transmissão reduzirá, progressivamente, as atuais restrições que, como afirma a Nota de Esclarecimento, atendem aos critérios de não restrição propostos no Tool to calculate the emissions factor for an electrical system.

Com essa nova realidade redefine-se o número de subsistemas adotado até então, pelo primeiro grupo de trabalho constituído em julho de 2005 pela CIMGC, com o objetivo de disponibilizar aos proponentes de projetos candidatos ao MDL as informações necessárias à aplicação do método de cálculo $c$, da análise dos dados do despacho, que foi considerado como o mais adequado para determinar os fatores de emissão do SIN.

De acordo com a Nota de Esclarecimento (NE) publicada no site do Ministério da Ciência e Tecnologia a questão mais discutida se referiu à definição do número de subsistemas do SIN a ser adotado, que afinal convergiu para a adoção de quatro subsistemas: Norte, Nordeste, Sudeste/Centro-Oeste e Sul, que passaram a ser calculados sistematicamente pelo ONS a partir de janeiro de 2006 e divulgados na página da CIMGC (MCT, 2008).

No entanto, tal procedimento foi bastante questionado, tendo em vista que a maioria dos projetos submetidos à CIMGC considerava apenas os subsistemas Norte/Nordeste e Sudeste/Centro-Oeste/Sul. Por essa razão a CIMGC reabriu as discussões, por meio de consulta pública realizada entre 7 de dezembro de 2007 a 31 de janeiro de 2008, solicitando comentários sobre a aplicação da metodologia ACM 0002 no Brasil.

Em fevereiro de 2008, após avaliar as submissões, a CIGMC examinou as alternativas da divisão em quatro e dois subsistemas e do sistema único, à luz

\footnotetext{
90 - Mais detalhes e justificativa encontram-se na Nota de Esclarecimento do Ministério da Ciência e Tecnologia e da Comissão Interministerial de Mudança Global do Clima (CIMGC), publicada no site: $\underline{\text { www.mct.gov.br }}$
} 
dos critérios propostos no Tool to calculate the emissions factor for an electrical system, version 1, que havia sido recentemente aprovada pelo Comitê Executivo do MDL para calcular o fator de emissão de sistemas elétricos.

Essa ferramenta sugere dois critérios para a identificação de restrições significativas de transmissão entre dois subsistemas, a saber:

a) No caso de sistemas elétricos com mercados "spot", quando houver diferenças nos preços de eletricidade (sem custos de transmissão e distribuição) de mais de $5 \%$ entre os sistemas durante $60 \%$ ou mais das horas do ano;

b) Quando a linha de transmissão operar a $90 \%$ ou mais que sua capacidade plena durante $90 \%$ ou mais das horas do ano.

Os resultados das simulações realizadas com base nestes critérios mostraram que

as restrições de transmissão existentes atualmente entre os submercados do SIN não eram suficientes para diminuir substancialmente o benefício global do projeto, em função da região em que seja implantado, sendo, portanto, recomendável que se adote a configuração de um único sistema elétrico no Brasil $(\mathrm{MCT}, 2008)^{91}$.

Em face às essas novas conclusões, a CIMGC passou a divulgar os novos fatores de emissão, retroativos a 2006, ressaltando,

que a adoção desta configuração será válida apenas para efeitos de cálculo dos fatores de emissão de dióxido de carbono $\left(\mathrm{CO}_{2}\right)$ em projetos de MDL que utilizem metodologia ACM 0002 para estimar suas reduções de emissão de gases de efeito estufa (Ibid.).

A configuração atual, ou seja, a divisão do SIN em quatro subsistemas - Sul, Sudeste/Centro-Oeste, Nordeste e Norte - deverá ser mantida para todas as demais necessidades de planejamento, operação e comercialização da energia elétrica.

\footnotetext{
91 - Nota de esclarecimento MCT/CIMGC, que se encontra publicada no site: $\underline{w w w . m c t . g o v . b r}$
} 
6.2.1.1 Características do SIN e suas implicações para estimar a LB dos projetos $M D L$

O SIN é um sistema hidrotérmico de grande porte que fornece energia elétrica à quase totalidade dos consumidores localizados em território nacional. De acordo com o ONS, apenas 3,4\% da capacidade de produção de eletricidade do país encontra-se atualmente fora do SIN, em pequenos sistemas isolados localizados principalmente na região amazônica. A Figura 5 mostra o mapa da integração eletroenergética do SIN e do sistema de transmissão em 2007.

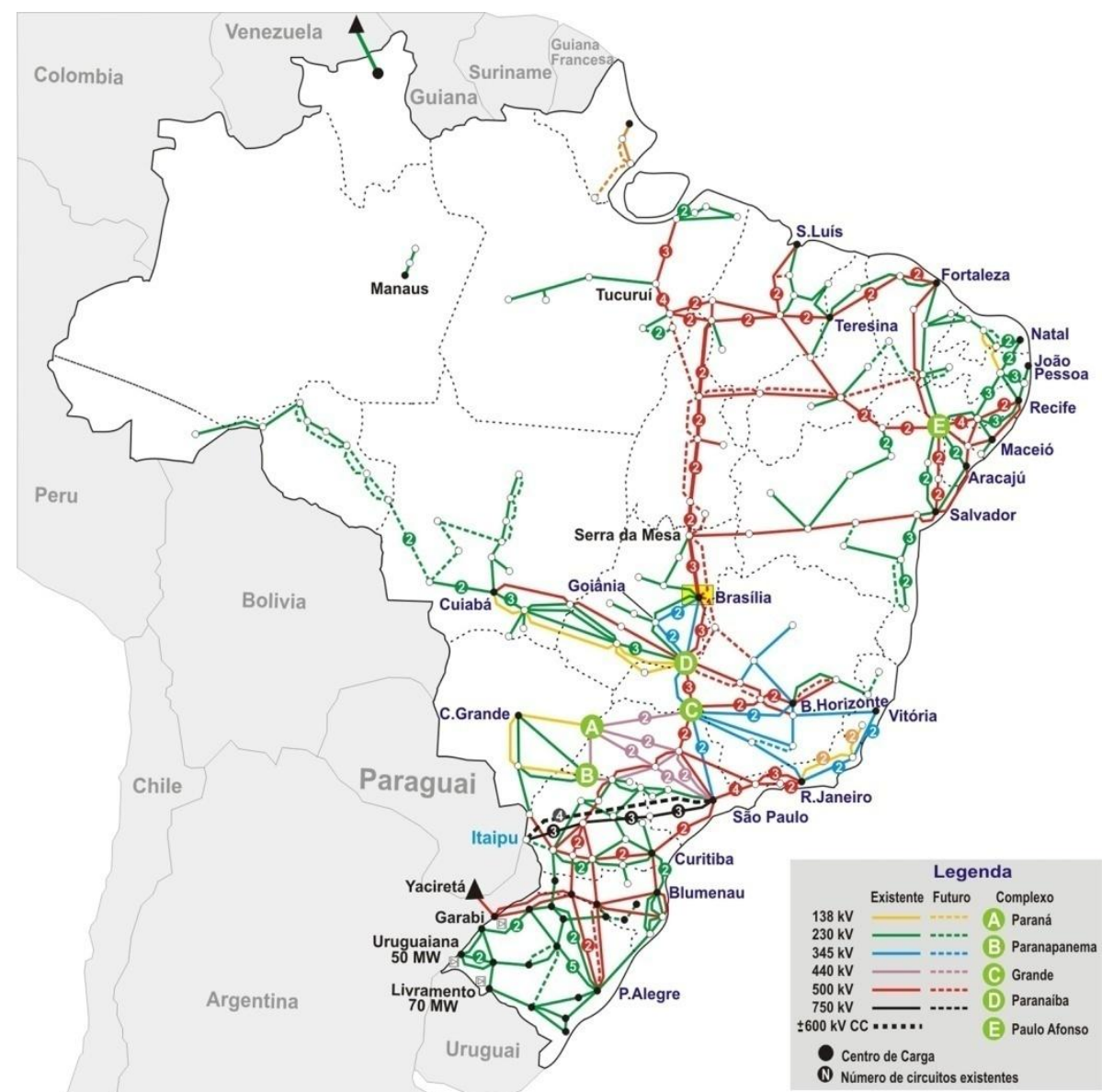

Figura 5: Mapa do Sistema de Transmissão (2007)

Fonte: ONS, consultado em 07/03/2009. Disponível no site:

http://www.ons.org.br/conheca_sistema/pop/pop_integracao_eletroenergetica.aspx 
Em dezembro de 2007 a capacidade instalada do SIN totalizou 96.243 MW, Tabela 15, assim distribuídos: $79.750 \mathrm{MW}$ em usinas hidroelétricas (82,9\%), 13.093 MW em usinas termoelétricas (13,6\%), $975 \mathrm{MW}$ em usinas do PROINFA $(1,0 \%)$ e $2.425 \mathrm{MW}$ em outras PCHs e PCTs $(2,5 \%)$.

Tabela 15 - Capacidade Instalada no SIN em 31/12/2007(MW)

\begin{tabular}{|c|c|c|c|}
\hline & TIPO & 2007 & $\%$ \\
\hline \multirow[t]{8}{*}{ SIN sem Acre-Rondônia } & Hidráulica & 66.295 & 68,9 \\
\hline & Térmica & 11.086 & 11,5 \\
\hline & Nuclear & 2.007 & 2,1 \\
\hline & PROINFA - PCHs & 268 & 0,3 \\
\hline & PROINFA - PCTs & 489 & 0,5 \\
\hline & PROINFA - Eólicas & 218 & 0,2 \\
\hline & Outras $\mathrm{PCH}$ e PCT & 2.425 & 2,5 \\
\hline & Total & 82.788 & \\
\hline
\end{tabular}

\begin{tabular}{lcrr}
\hline Itaipu $60 \mathrm{~Hz}$ (Brasil) & $(50 \%$ Total) & 7.000 & 7,3 \\
\hline Subtotal & Capacidade Instalada & $\mathbf{8 9 . 7 8 8}$ & \\
\hline Itaipu $50 \mathrm{~Hz}$ (Paraguai) & Compras Itaipu & 6.455 & 6,7 \\
\hline
\end{tabular}

Total disponível com Itaipu 50 e $60 \mathrm{~Hz}$

96.243

Fonte: ONS, 2008b

A predominância da geração elétrica a partir de fonte hídrica em um sistema interligado do porte e extensão do SIN é uma importante característica, cuja especificidade o torna único em todo o mundo. Com efeito, em 2007, mais de $83 \%$ de toda a eletricidade gerada foi proveniente das usinas hidrelétricas. Destaque-se ainda que dos empreendimentos em construção, $73 \%$ da potência outorgada refere-se a usinas hidrelétricas, $21 \%$ a centrais termelétricas e $6 \%$ a centrais eólicas. Na Tabela 16 os empreendimentos em construção listados pela ANEEL. 
Tabela 16 - Empreendimentos em construção

\begin{tabular}{cccr}
\hline Tipo & Na Usina & Potência Outorgada - MW & $\%$ \\
\hline Central Geradora Hidrelétrica & 1 & 0,85 & 0 \\
Central Geradora Eliolétrica & 22 & 463 & 6 \\
Pequena Central Hidrelétrica & 68 & 1.095 & 15 \\
Usina Hidrelétrica & 21 & 4.318 & 58 \\
Usina Termelétrica & 20 & 1.541 & 21 \\
\hline TOTAL & 132 & 7418 & 100 \\
\hline
\end{tabular}

Fonte: ANEEL - BIG Banco de Informação da Geração. Consultada outubro/2008

Vale ressaltar, no entanto, que entre 2009 e 2013 as novas capacidades instaladas serão, majoritariamente, de fonte térmica convencional (usinas movidas a óleo combustível e gás natural) como mostram os resultados dos sete leilões de energia nova, A3 e A5, apresentados na Tabela 1 do Capítulo de Introdução do presente trabalho.

Levando-se em conta, portanto, esses resultados, um pouco mais de 17.000 MW médios foram contratados para o sistema elétrico brasileiro. Da energia contratada por fonte de recurso energético nesses leilões, $60 \%$ foram de origem térmica e $38 \%$ de origem hídrica. Do total da oferta térmica, $2 \%$ serão fornecidos por usinas movidas à biomassa, não emissoras dos GEE. Levando-se em conta a oferta de energia nova até 2013, a participação das fontes térmicas convencionais (emissoras de GEE) eleva-se para $68 \%$ do total contratado.

Além disso, de acordo com o PDEE 2008-2017(MME, 2008) prevê-se uma ampliação significativa das termelétricas movidas a combustíveis fósseis no SIN. Com efeito, nesse período o número de termelétricas mais que dobrará, passando das atuais 77 para 159, com um acréscimo líquido de 82 centrais termelétricas, com acréscimo de $15.305 \mathrm{MW}^{92}$.

Em termos de consumo de energia elétrica, segundo recente estudo divulgado pela Empresa de Planejamento Energético (MME/EPE, 2008) prevê-se um

\footnotetext{
92 - De acordo com informações divulgadas pelo MME e publicadas no jornal Folha de São Paulo, em 07/01/2009.
} 
crescimento anual do consumo de eletricidade do SIN da ordem $4,8 \%$, passando de 369.398 GWh consumidos em 2007 para 602.596 GWh projetados para 2017.

O Gráfico 21 mostra a projeção do consumo de eletricidade, incluindo os sistemas isolados entre 2007-2017 e não incluindo o consumo dos autoprodutores. Essa projeção incorpora parte das perdas comerciais e desconta do consumo total uma parcela relacionada ao incremento da eficiência energética, estimada para o período decenal. De acordo com o documento mencionado,

com a integração ao SIN dos sistemas isolados Acre/Rondônia e Manaus/Amapá, ao longo do horizonte decenal, o Sistema Interligado Nacional englobará 99,7\% do mercado nacional de energia elétrica em 2017 (MME/EPE, 2008, p.64)

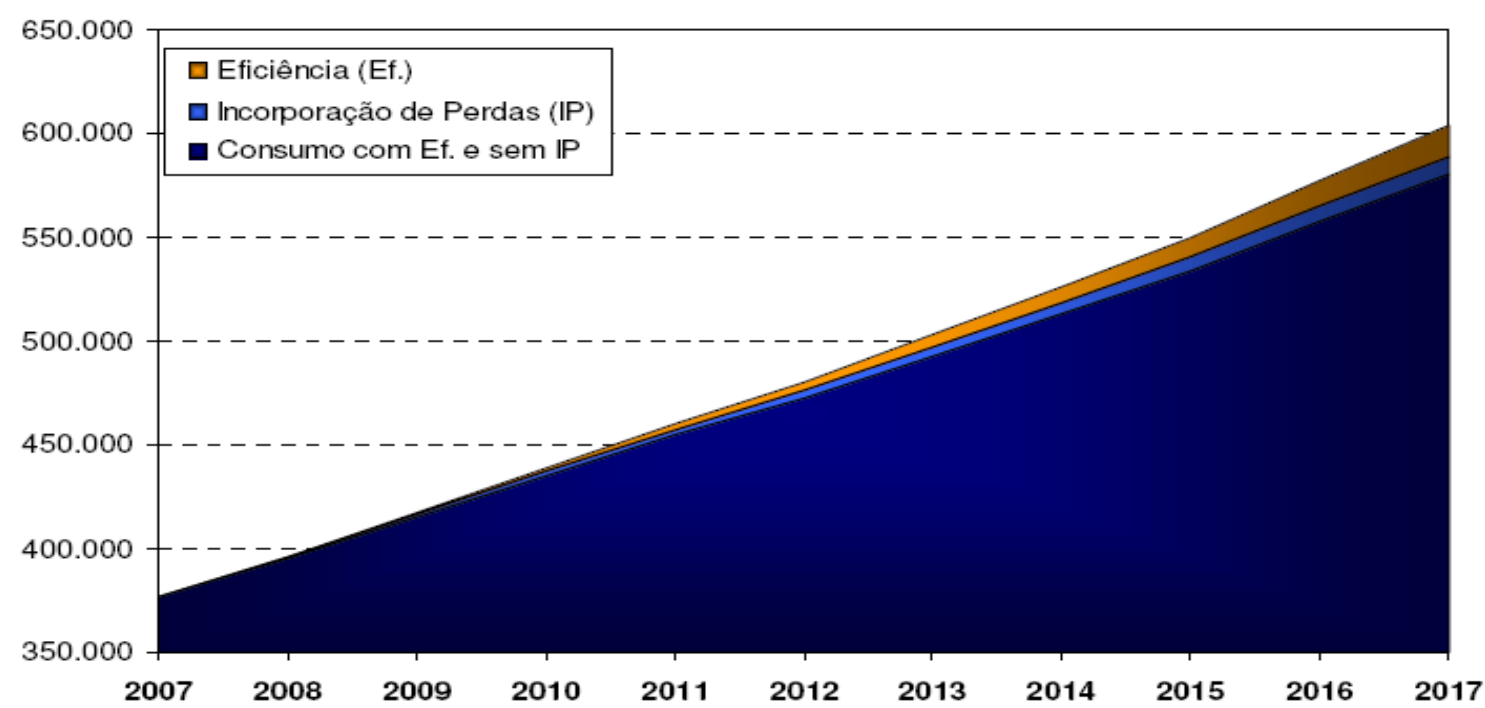

Gráfico 20 - Consumo de eletricidade com perdas e eficiência energética - GWh Fonte: MME/EPE, 2008, p.65

A projeção da carga de energia é feita a partir das projeções de consumo acrescida da estimativa de perdas. A estimativa feita pela EPE admitiu que 0 índice de perda passe dos atuais 16,2\% para 14,9\%, em 2017. Portanto, considerando essas projeções será necessário adicionar, em torno de 12.300 MW médios, entre 2008 e 2012 e mais 15.700 MW médios, entre 2012 e 2017 para atender aos requisitos de mercado (Ibid.). 
Do ponto de vista da determinação dos fatores de substituição das emissões, a extrema dependência do volume de eletricidade gerada ao comportamento da hidraulicidade das bacias que alimentam os reservatórios que servem ao SIN confere ao cálculo dos fatores projetados, enormes dificuldades e incertezas, qualquer que seja a metodologia adotada.

Com efeito, embora a contratação das novas capacidades e/ou as tecnologias associadas às usinas que estão sendo construídas possam se constituir num importante indicativo sobre o perfil futuro do mix que provavelmente responderá pelo fornecimento de energia elétrica para atender aos requisitos do sistema elétrico interligado, deve ser considerado, do ponto de vista do cálculo das emissões, de forma conservadora, com base nos cenários construídos e/ou simulações sobre a sua efetiva utilização, ao longo do horizonte do estudo.

Essas dificuldades e incertezas se tornam ainda mais profundas, na medida em que também a política operativa do SIN vem sendo constantemente modificada, para atender aos novos critérios de segurança energética e para ajustar-se às novas condicionantes relativas ao fornecimento de gás natural para as usinas movidas a esse combustível e que são interligadas ao sistema elétrico.

No entanto, se o objetivo é estimar a linha de base de um projeto de MDL conectado ao SIN, não há como escapar a esse desafio, a menos que o Comitê Executivo (CE) do MDL aceite que a linha de base adotada por um determinado projeto não seja monitorado anualmente. Como o fator de emissão do SIN já está sendo calculado pela CIMGC pelo método $c$, da análise dos dados do despacho, por definição, ele terá que ser monitorado e anualmente atualizado ${ }^{93}$.

Até outubro de 2008, nenhum projeto aprovado, aprovado com ressalva e em revisão na CIMGC a ser conectado ao SIN, adotou os fatores de emissão calculados de acordo com o Tool to calculate the emission factor for an electricity

\footnotetext{
93 - Mais detalhes sobre a obrigatoriedade do monitoramento e atualização anual do fator de emissão quando calculado pelo método da análise dos dados do despacho encontram-se no Apêndice A do presente trabalho.
} 
system, versão 1, o que permitiu a esses projetos usarem a opção ex-ante de validação dos dados.

A expectativa para os novos projetos que solicitem a aprovação da CIMGC e requeiram seu registro junto ao $\mathrm{CE}$ do $\mathrm{MDL}$ é que eles não mais poderão fazer a opção ex-ante de validação dos dados, já que se encontram publicados pela CIGMC os fatores de emissão calculados pelo método $c$, da análise dos dados do despacho, e como acima foi mencionado, não permite a validação ex-ante do fator de emissão do sistema elétrico.

Confirmando-se essa hipótese então, necessariamente, o proponente do projeto terá que internalizar ao seu processo de decisão a construção de cenários sobre o comportamento futuro das emissões do SIN, concomitantemente ao desenvolvimento do projeto, em caso de a viabilidade e sustentabilidade desse projeto depender da inclusão ao seu fluxo de caixa das receitas adicionais oriundas dos créditos de carbono.

\subsubsection{Período de obtenção de crédito}

Adota-se o período de 10 anos como opção para obtenção dos créditos de carbono, para todos os experimentos realizados nesse estudo de caso. Essa opção foi escolhida em função da disponibilidade de dados sobre os requisitos de carga e sobre o planejamento da expansão do sistema nacional interligado entre 2007 e 2016. No entanto, desde que o proponente do projeto de MDL disponha das informações necessárias para construir cenários de mais longo prazo ele poderá fazê-lo, sendo recomendada a sua atualização anual. 


\subsubsection{Oferta na configuração de base}

A configuração de base é definida pela capacidade instalada no SIN, em dezembro/2007, pela oferta de energia elétrica estabelecida nos leilões de energia nova A3 e A5 e pelos empreendimentos planejados no PDE 2007/2016, corrigidas pelo cronograma da ANEEL, e pela oferta de gás natural (GN) de acordo com o Termo de Compromisso da Petrobras $^{94}$, de maio/2007, que estabelece a disponibilidade das usinas a gás natural (GN) até 2011. A lista completa das usinas que compõem a configuração de base encontra-se nos APÊNDICES B e C.1, C.2, C.3, C.4 do presente estudo.

Destaca-se que o programa de eficiência energética planejado no PDE 20072016, que prevê uma economia anual, em 2011, de quase 500 MW médios, não foi considerado na configuração inicial para calcular o fator de substituição (linha de base) dos projetos de MDL enquadrados no primeiro grupo de experimentos ${ }^{95}$.

A conseqüência mais imediata desse pressuposto é que os Fatores de Substituição (FS) calculados para os experimentos realizados são ligeiramente maiores do que aqueles encontrados, admitindo-se a entrada do programa de eficiência, em parte ou na sua totalidade, na configuração de base, a partir de 2011. Justifica-se a não inclusão do programa pelo fato de que, sendo um

${ }^{94}$ - O Termo de Compromisso estabelece cronograma de oferta de combustíveis para 24 usinas termelétricas das regiões Sul, Sudeste, Centro-Oeste e Nordeste, no período de 2007 a 2011. O documento prevê a aplicação de penalidades à estatal por descumprimento do acordo preestabelecido, em caso de indisponibilidade de geração dessas usinas motivada por falta de combustível. A decisão da ANEEL atende determinação da Resolução Normativa № 237/2006, que prevê a inclusão, na programação de despacho do Operador Nacional do Sistema Elétrico (ONS), da disponibilidade de empreendimentos termelétricos que tenham cronograma de suprimento de combustível reconhecido pela Agência.

95 - Todos os experimentos realizados com a aplicação dessa abordagem metodológica para calcular o fator de substituição de projetos de MDL encontram-se descritos no item 6.3 do presente Capítulo. 
programa de eficiência energética potencialmente elegível para o MDL a linha de base não deveria contê-lo.

6.2.2.2 Requisitos (MW médios) e nível dos reservatórios equivalentes na configuração de base

Para definir a carga média de energia do SIN, que representa o requisito de geração de energia elétrica na barra das usinas para o atendimento do mercado, considerou-se a trajetória inferior do PDE 2007-2016 (MME, 2007), cujos dados de demanda se encontram na Tabela 17. Essa trajetória mostrou-se mais compatível com os requisitos observados em 2007 e primeiros meses de 2008 e também mais ajustada às novas projeções realizadas pela EPE para o período entre 2008-2017.

A projeção da carga de energia considera as interligações previstas dos sistemas isolados Acre/Rondônia ao subsistema Sudeste/Centro-Oeste, a partir do início de 2009, e Manaus/Amapá e margem esquerda do Rio Amazonas ao subsistema Norte, no início de 2012, aproximando-se da provável evolução futura da configuração do Sistema Interligado Nacional - SIN (EPE, 2008a).

Tabela 17 - Carga média de energia SIN - MW médios

\begin{tabular}{cccccc}
\hline \multirow{2}{*}{ Ano } & \multicolumn{5}{c}{ Subsistemas Interligados } \\
& Norte & NE & SE & Sul & \\
\hline 2007 & 3502 & 7324 & 31421 & 8320 & 50567 \\
2008 & 3773 & 7653 & 32959 & 8696 & 53081 \\
2009 & 3946 & 7995 & 34594 & 9148 & 55683 \\
2010 & 4083 & 8550 & 36080 & 9626 & 58339 \\
2011 & 4365 & 8936 & 37596 & 10030 & 60927 \\
2012 & 5759 & 9383 & 39279 & 10463 & 64884 \\
2013 & 5966 & 9796 & 41241 & 10905 & 67908 \\
2014 & 6220 & 10327 & 42943 & 11458 & 70948 \\
2015 & 6950 & 10879 & 44878 & 11978 & 74685 \\
2016 & 7784 & 11404 & 46706 & 12495 & 78389 \\
$2017^{96}$ & 8718 & 11954 & 48608 & 13034 & 82315 \\
\hline
\end{tabular}

Fonte: MME, 2007

96 - Para determinar a demanda em 2017 assumiu-se no presente trabalho uma taxa de crescimento igual àquela observada entre 2016/2015. 
Energia inicial acumulada nos reservatórios

A energia inicial acumulada nos reservatórios, Tabela 20, refere-se a dezembro de 2007 , conforme publicada pelo ONS.

Tabela 18 - Energia inicial acumulada em MW médio - dez./2007 ${ }^{97}$

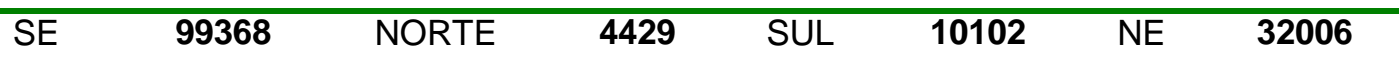

6.2.2.3 Cálculo da energia gerada (MWh) na configuração de base

Para calcular as energias a serem geradas mensalmente ( $\mathrm{MWh}$ ) pelas usinas em operação e planejadas (PDEE 2007- 2016) e as usinas contratadas nos leilões de energia nova A3 e A5, no período entre 2008 e 2017, aplicou-se o modelo de equilíbrio entre oferta e demanda de energia elétrica, cujos dados de entrada e a modelagem do despacho são descritos a seguir:

1. Usinas Hidrelétricas existentes, inclusive as $\mathrm{PCHs} e$ os novos empreendimentos hidrelétricos contratados nos leilões de energia nova A3 e A5 e nos leilões das usinas de Santo Antonio e Jirau e planejados pelo cronograma da $A N E E L^{98}$ : A energia assegurada pelas usinas hidrelétricas é determinada em função da ENA prevista para o período em cada uma das séries, considerando um fator de disponibilidade inicial das hidrelétricas de 90\%. As informações detalhadas desses empreendimentos encontram-se nos Apêndices acima mencionados;

\footnotetext{
97 - Tabela elaborada a partir das informações do ONS (2008d)

98 - Cronograma da ANEEL encontra-se no site: www.aneel.gov.br, na seção de informações técnicas, em fiscalização dos serviços de geração.
} 
2. Usinas Termelétricas existentes e as novas usinas contratadas nos leilões de energia nova $A 3$ e A5: As energias a serem geradas pelas usinas entrantes, entre 2008 e 2017, foram definidas em função da capacidade da energia disponível e do custo variável delas explicitados na Nota Técnica de revisão do cálculo da garantia física das usinas publicado pela EPE (2008a e 2008b), em agosto e setembro de 2008 e pelo Termo de Compromisso da Petrobrás para as térmicas a gás natural entre 2007 e 2011. Para as usinas existentes as energias geradas foram estimadas com base na potência instalada e nos fatores de capacidade estimados;

3. O despacho na base das usinas térmicas convencionais inflexíveis, termonucleares e PCHs, conforme previsto na Nota Técnica da EPE (2008b) e no PDE 2007-2016 corrigido pelo cronograma da ANEEL;

4. O despacho por ordem de mérito das termelétricas convencionais flexíveis, movidas a gás natural, óleo combustível, carvão e biomassa. O despacho das usinas hidrelétricas é calculado pelo modelo a partir dos níveis dos reservatórios, com a aplicação de uma fórmula própria ${ }^{99}$, que calcula o custo de oportunidade da água para ordenar o despacho hidrotérmico.

Na Tabela 19 apresentam-se os resultados distribuídos da energia anual ofertada pelas usinas térmicas flexíveis na configuração de base calculadas pelo modelo equilíbrio integrado.

Tabela 19 - Geração de térmicas flexíveis no SIN por ano e para todo o período - (TWh)

\begin{tabular}{cccccccccccc}
\hline & $2008-$ & 2008 & 2009 & 2010 & 2011 & 2012 & 2013 & 2014 & 2015 & 2016 & 2017 \\
& 2017 & & & & & & & & & & \\
\hline Mínimo & 266 & 10 & 5 & 6 & 5 & 7 & 5 & 7 & 10 & 10 & 25 \\
p05 & 369 & 16 & 10 & 12 & 13 & 19 & 22 & 22 & 27 & 35 & 50 \\
1ㅇ- Quartil & 444 & 25 & 18 & 20 & 22 & 32 & 37 & 35 & 41 & 53 & 73 \\
Mediana & 501 & 35 & 25 & 29 & 31 & 43 & 49 & 48 & 53 & 68 & 91 \\
3o Quartil & 560 & 46 & 36 & 41 & 42 & 58 & 67 & 64 & 70 & 88 & 113 \\
p95 & 651 & 56 & 57 & 65 & 66 & 86 & 99 & 93 & 101 & 122 & 145 \\
Máximo & 816 & 60 & 88 & 111 & 120 & 137 & 165 & 150 & 164 & 162 & 168 \\
\hline Média & 505 & 35 & 28 & 32 & 34 & 47 & 54 & 51 & 57 & 72 & 94 \\
\hline
\end{tabular}

\footnotetext{
99 - Mais detalhes sobre o cálculo do preço da água no modelo MEl encontra-se no Capítulo 4 do
} presente trabalho. 
As séries de ENA (2000 séries) são geradas internamente pelo modelo no módulo QPAR ${ }^{100}$ (modelo auto-regressivo quantílico). Com aplicação do modelo de equilíbrio são obtidas 2000 séries de oferta térmica (em $\mathrm{MW}_{\text {médios}}$ ), para cada mês do período entre 2008/2017. Cada série agregada de oferta térmica corresponde a uma solução possível de equilíbrio entre a oferta e a demanda por energia elétrica, atendendo aos critérios do despacho por ordem de mérito e garantia da segurança energética.

O mesmo procedimento é adotado para simular a configuração final, que se caracteriza pela entrada das atividades do projeto MDL no sistema elétrico, conforme proposto no item 4 do Capítulo 5, que trata dos procedimentos para aplicação dessa metodologia.

Encontra-se no Capítulo 4 do presente trabalho o resumo do modelo, contendo:

$\checkmark$ Descrição do Modelo de Equilíbrio Integrado, explicitando premissas, estrutura e operacionalidade e fluxograma;

$\checkmark$ Descrição dos módulos que o compõe, a saber: Módulo QPAR de previsão de ENA e o Módulo de Vertimento e Perdas;

$\checkmark$ Gráficos das ENA projetadas pelo modelo, entre 2008 e 2017.

6.2.3 Cálculo das Emissões Totais $\left(E T_{S I N b}\right)$ e do Fator de Emissão (FE $\left.E_{S I N b}\right)$ : configuração de base

As emissões totais foram calculadas seguindo os procedimentos sugeridos nos passos 1 e 2 da proposta metodológica.

100 - Os modelos auto-regressivos periódicos são classicamente utilizados para se obter resultados futuros a partir da série histórica. A escolha por um modelo auto-regressivo periódico quantílico é feita no sentido de resolver o problema gerado pela heteroestocacidade encontrada normalmente na análise desta série de dados. A regressão pelos quantis flexibiliza a hipótese de variância homogênea e permite uma análise mais precisa das faixas de distribuição dos dados em cada momento no tempo (Adilson, et al., 2008). 
Assim, definidas as condições iniciais da geração hidrotérmica, composta pelas gerações das usinas em operação em dezembro de 2007, pelas gerações disponíveis dos empreendimentos vencedores dos leilões e pelas gerações calculadas para os empreendimentos planejados, bem como os requisitos de carga do SIN a serem atendidos no mesmo período, aplicou-se o modelo de equilíbrio para determinar as 2000 séries de gerações termelétricas flexíveis e calcular as emissões associadas a cada série.

Nos APÊNDICES D.1, D.2, D.3, e D.4 encontram-se as usinas térmicas despacháveis por subsistema, suas respectivas eficiências e fatores de emissões dos combustíveis fósseis, em $\mathrm{tCO}_{2} / \mathrm{MWh}$. Apresenta-se, a seguir um exemplo de como são calculadas as emissões associadas a cada usina térmica flexível no módulo de emissões, para cada uma das 2000 séries de despachos térmicos mensais simulados pelo modelo de equilíbrio, para todo o horizonte do estudo. Note-se que esses resultados se referem apenas a uma entre as 2000 séries de despachos flexíveis simuladas.

Exemplo da operacionalização do modelo de simulação, a partir de uma entrada de ENA, em um cenário pré-definido de requisitos e capacidade de oferta.

1. A série de número 700 , escolhida aleatoriamente para este exemplo, gerada pelo módulo de ENA, fornece os dados apresentados na Tabela 20, a seguir:

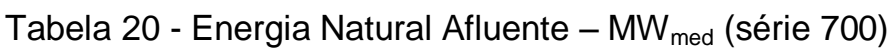

\begin{tabular}{lrrrrrrrrrrrr}
\hline \multicolumn{10}{c}{} & \multicolumn{10}{c}{2009} \\
\hline & \multicolumn{1}{c}{ Jan. } & \multicolumn{1}{c}{ Fev. } & \multicolumn{1}{c}{ Mar. } & \multicolumn{1}{c}{ Abr. } & Mai. & Jun. & Jul. & Ago. & Set. & Out. & Nov. & Dez \\
\hline SE & 69900,68 & 58113,62 & 42323,86 & 37040,74 & 29924,38 & 26450,19 & 23103,52 & 18946,37 & 20425,91 & 23824,43 & 30467,28 & 38047,80 \\
Sul & 4077,73 & 5881,89 & 4178,62 & 8237,61 & 4712,58 & 12020,61 & 10298,01 & 5423,07 & 3722,80 & 7081,11 & 7369,77 & 5729,92 \\
NE & 10918,14 & 13631,31 & 11770,93 & 16024,93 & 10372,52 & 6573,13 & 5401,69 & 4941,33 & 4433,62 & 4123,94 & 9565,51 & 12330,57 \\
Norte & 3320,87 & 9752,48 & 10654,51 & 17877,78 & 13205,42 & 4913,60 & 2664,06 & 1952,25 & 1554,32 & 1541,32 & 2634,83 & 4792,28 \\
\hline
\end{tabular}

2. Os requisitos do sistema, obtidos no PDE 2007-2016 a partir de um critério automático de sazonalização são os mesmos para todas as séries. Para 0 ano de 2009 seguem os dados da Tabela 21: 
Tabela 21 - Requisitos do sistema - $\mathrm{MW}_{\text {med }}$

\begin{tabular}{|c|c|c|c|c|c|c|c|c|c|c|c|c|}
\hline & \multicolumn{12}{|c|}{2009} \\
\hline & Jan. & Fev. & Mar. & Abr. & Mai. & Jun. & Jul. & Ago. & Set. & Out. & Nov. & Dez. \\
\hline SE & 34427,96 & 35174,75 & 35663,04 & 34948,69 & 33931,53 & 33590,03 & 34417,45 & 34065,04 & 34505,21 & 34882,92 & 34794,01 & 34727,38 \\
\hline Sul & 9423,13 & 9520,77 & 9684,04 & 8906,21 & 9011,82 & 8978,29 & 8745,86 & 9027,31 & 8792,23 & 8959,08 & 9258,78 & 9468,47 \\
\hline NE & 7843,23 & 7852,35 & 7961,44 & 7928,15 & 7868,20 & 7702,75 & 7854,97 & 7867,47 & 8072,01 & 8321,84 & 8402,09 & 8265,50 \\
\hline Norte & 3781,55 & 3805,64 & 3883,48 & 3906,37 & 3993,48 & 4038,33 & 3955,40 & 3969,51 & 3985,65 & 3966,38 & 4072,19 & 3994,04 \\
\hline
\end{tabular}

3. Em função da quantidade de energia hidrelétrica necessária para atender plenamente os requisitos, o modelo calcula o custo marginal de operação do sistema, por meio de uma fórmula própria pautada em critérios de segurança energética, apresentados na Tabela 22.

Tabela 22 - Custos marginais de operação - R\$/MWh

\begin{tabular}{lccccccccccccc}
\hline \multicolumn{10}{c}{} & \multicolumn{10}{c}{2009} \\
\hline & Jan. & Fev. & Mar. & Abr. & Mai. & Jun. & Jul. & Ago. & Set. & Out. & Nov. & Dez. \\
\hline SE & 15,47 & 30,90 & 78,94 & 88,75 & 124,63 & 95,95 & 102,75 & 107,73 & 111,75 & 123,27 & 104,36 & 111,80 \\
Sul & 15,47 & 30,98 & 79,21 & 88,83 & 126,70 & 96,35 & 102,40 & 112,54 & 114,76 & 121,91 & 103,70 & 115,72 \\
NE & 15,47 & 18,00 & 28,28 & 25,84 & 58,70 & 70,52 & 85,17 & 103,83 & 111,89 & 122,70 & 103,83 & 111,84 \\
Norte & 15,47 & 17,43 & 15,47 & 15,47 & 15,47 & 96,35 & 102,40 & 106,98 & 110,81 & 124,62 & 103,70 & 111,06 \\
& & & & & & & & & & & & \\
\hline
\end{tabular}

4. A partir do custo estimado de despacho, as usinas térmicas com custo inferior ou igual ao calculado, apresentadas na Tabela 23, são despachadas e sua capacidade disponível reduzida do uso das hidrelétricas, permitindo que se poupe água quando necessário. 
Tabela 23 - Usinas do Sudeste despachadas em 2009, por capacidade, em MW médios

\begin{tabular}{|c|c|c|c|c|c|c|c|c|c|c|c|c|}
\hline & \multicolumn{12}{|c|}{2009} \\
\hline & Jan. & Fev. & Mar. & Abr. & Mai. & Jun. & Jul. & Ago. & Set. & Out. & Nov. & Dez. \\
\hline Mário Covas (Cuiabá) & 419,73 & 419,73 & 419,73 & 419,73 & 419,73 & 419,73 & 419,73 & 419,73 & 419,73 & 419,73 & 419,73 & 419,73 \\
\hline Norte Fluminense 1 & 0,00 & 0,00 & 0,00 & 0,00 & 0,00 & 0,00 & 0,00 & 0,00 & 0,00 & 0,00 & 0,00 & 0,00 \\
\hline Colorado & 0,00 & 0,00 & 14,00 & 14,00 & 14,00 & 14,00 & 14,00 & 14,00 & 14,00 & 14,00 & 14,00 & 14,00 \\
\hline Norte Fluminense 2 & 0,00 & 0,00 & 274,05 & 274,05 & 274,05 & 274,05 & 274,05 & 274,05 & 274,05 & 274,05 & 274,05 & 274,05 \\
\hline Norte Fluminense 3 & 0,00 & 0,00 & 73,95 & 73,95 & 73,95 & 73,95 & 73,95 & 73,95 & 73,95 & 73,95 & 73,95 & 73,95 \\
\hline Do Atlântico & 0,00 & 0,00 & 0,00 & 0,00 & 0,00 & 0,00 & 0,00 & 0,00 & 0,00 & 0,00 & 0,00 & 0,00 \\
\hline Norte Fluminense 4 & 0,00 & 0,00 & 0,00 & 0,00 & 60,03 & 0,00 & 0,00 & 0,00 & 60,03 & 60,03 & 0,00 & 60,03 \\
\hline Luiz Carlos Prestes (Três & 0,00 & 0,00 & 0,00 & 0,00 & 182,92 & 0,00 & 0,00 & 0,00 & 182,92 & 182,92 & 0,00 & 182,92 \\
\hline Lagoas) & & & & & & & & & & & & \\
\hline Cocal & 0,00 & 0,00 & 0,00 & 0,00 & 26,88 & 0,00 & 0,00 & 0,00 & 0,00 & 26,88 & 0,00 & 0,00 \\
\hline $\begin{array}{l}\text { Gov. Leonel Brizola } \\
\text { (Termorio) }\end{array}$ & 0,00 & 0,00 & 0,00 & 0,00 & 0,00 & 0,00 & 0,00 & 0,00 & 0,00 & 0,00 & 0,00 & 0,00 \\
\hline
\end{tabular}

5. Em seguida, a partir do calculo das eficiências médias por tipo de combustível, converte-se a energia gerada em toneladas de dióxido de carbono $\left(\mathrm{CO}_{2}\right)$. Os resultados são apresentados na Tabela 24.

Tabela 24 - Emissões por usina conforme o despacho estimado - milhares de $\mathrm{tCO}_{2}$

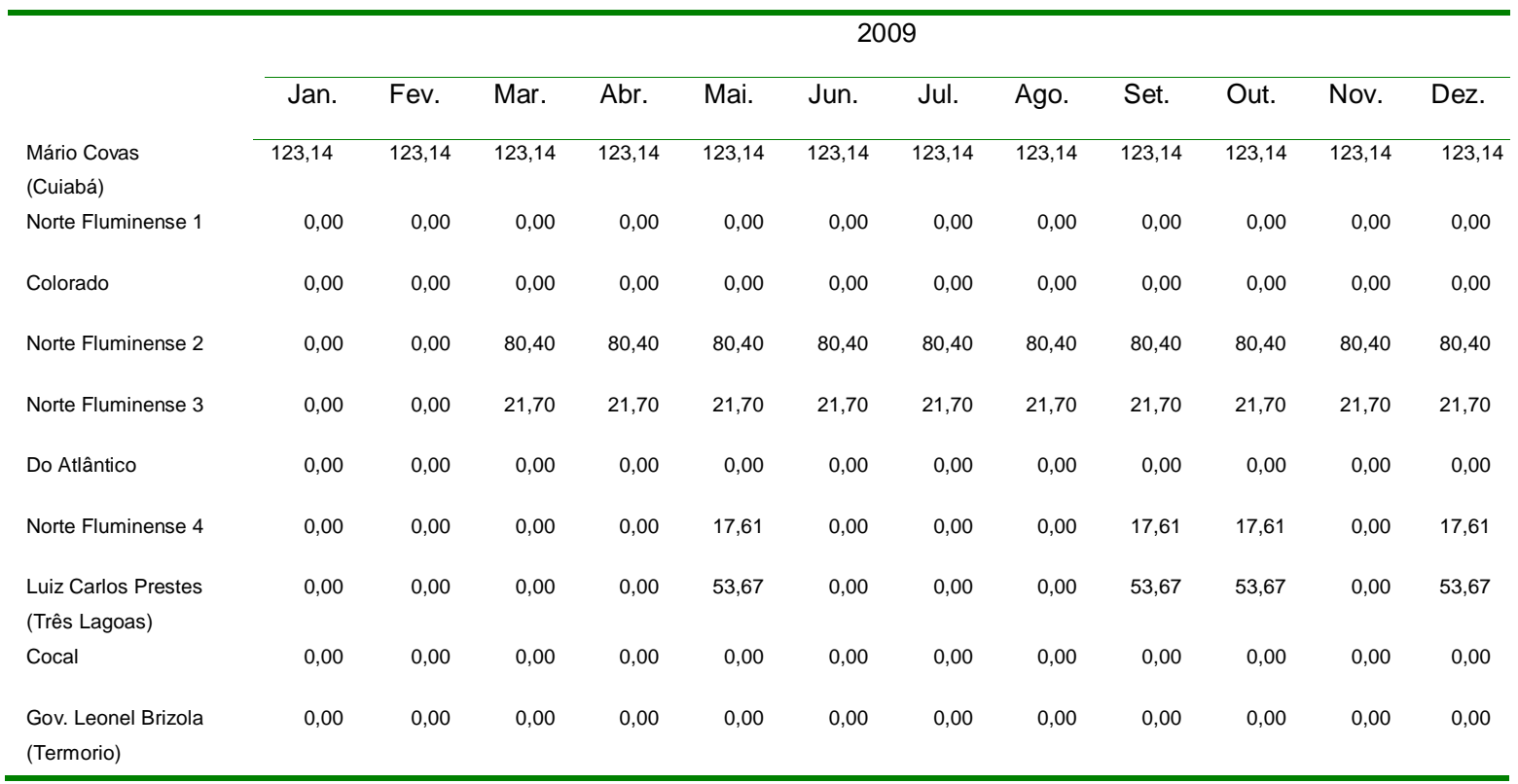

6. Os valores da emissão do $\mathrm{CO}_{2}$ associado à produção de energia são então registrados para o cenário de base. $O$ processo é re-simulado para 
um cenário que conta com a entrada de uma usina com energia limpa, não emissora. A geração relativa à usina limpa entrante é descontada diretamente da demanda de energia, pois é considerada como despacho na base. O restante da demanda é então redistribuído através do modelo pelas outras usinas conforme a ordem de mérito. Isto é feito por meio de uma nova rodada do modelo. A Tabela 25 apresenta esses resultados com as novas emissões.

Tabela $25-\mathrm{CO}_{2}$ evitado por usina de $100 \mathrm{MW}$ médios - milhares de $\mathrm{t} \mathrm{CO}_{2}$

\begin{tabular}{|c|c|c|c|c|c|c|c|c|c|c|c|c|}
\hline & & & & & & & & & & & & \\
\hline & Jan. & Fev. & Mar. & Abr. & Mai. & Jun. & Jul. & Ago. & Set. & Out. & Nov. & Dez. \\
\hline $\begin{array}{l}\text { Mário Covas } \\
\text { (Cuiabá) }\end{array}$ & 123,14 & 123,14 & 123,14 & 123,14 & 123,14 & 123,14 & 123,14 & 123,14 & 123,14 & 123,14 & 123,14 & 123,14 \\
\hline Norte Fluminense 1 & 0,00 & 0,00 & 0,00 & 0,00 & 0,00 & 0,00 & 0,00 & 0,00 & 0,00 & 0,00 & 0,00 & 0,00 \\
\hline Colorado & 0,00 & 0,00 & 0,00 & 0,00 & 0,00 & 0,00 & 0,00 & 0,00 & 0,00 & 0,00 & 0,00 & 0,00 \\
\hline Norte Fluminense 2 & 0,00 & 0,00 & 80,40 & 80,40 & 80,40 & 80,40 & 80,40 & 80,40 & 80,40 & 80,40 & 80,40 & 80,40 \\
\hline Norte Fluminense 3 & 0,00 & 0,00 & 21,70 & 21,70 & 21,70 & 21,70 & 21,70 & 21,70 & 21,70 & 21,70 & 21,70 & 21,70 \\
\hline Do Atlântico & 0,00 & 0,00 & 0,00 & 0,00 & 0,00 & 0,00 & 0,00 & 0,00 & 0,00 & 0,00 & 0,00 & 0,00 \\
\hline Norte Fluminense 4 & 0,00 & 0,00 & 0,00 & 0,00 & 0,00 & 0,00 & 0,00 & 0,00 & 0,00 & 0,00 & 0,00 & 0,00 \\
\hline $\begin{array}{l}\text { Luiz Carlos Prestes } \\
\text { (Três Lagoas) }\end{array}$ & 0,00 & 0,00 & 0,00 & 0,00 & 0,00 & 0,00 & 0,00 & 0,00 & 0,00 & 0,00 & 0,00 & 0,00 \\
\hline Cocal & 0,00 & 0,00 & 0,00 & 0,00 & 0,00 & 0,00 & 0,00 & 0,00 & 0,00 & 0,00 & 0,00 & 0,00 \\
\hline $\begin{array}{l}\text { Gov. Leonel Brizola } \\
\text { (Termorio) }\end{array}$ & 0,00 & 0,00 & 0,00 & 0,00 & 0,00 & 0,00 & 0,00 & 0,00 & 0,00 & 0,00 & 0,00 & 0,00 \\
\hline
\end{tabular}

7. Por diferença entre os dois cenários (com e sem usina limpa) são obtidas as emissões evitadas para o ano de 2009, na região Sudeste. As emissões evitadas dentro do período de um ano são então somadas para todas as regiões e o valor total obtido é dividido pela capacidade efetiva da usina limpa. Este é o fator anual de emissão para o sistema dada à entrada de capacidade limpa.

Seguindo o exemplo acima, e considerando apenas a série 700 da região Sudeste deste exemplo, o fator de substituição para 2009 é de 0,33 t $\mathrm{CO}_{2} / \mathrm{MWh}$, obtido pela divisão entre as emissões evitadas no ano de 2009 no SE, de 285,12 mil t $\mathrm{CO}_{2}$ e a geração da usina entrante de $100 \mathrm{MW}_{\text {med, }}$ ou 876.000 MWh. 
Os experimentos foram realizados para um período de dez anos e para diversas capacidades entrantes. Para o período de dez anos, a contabilização das emissões foi feita de duas formas: por ano, como mostrado acima, e cumulativamente, a partir da média das emissões acumulada até o ano, para todo o período considerado (10 anos) de obtenção de créditos.

O segundo método apresenta a vantagem de mostrar o comportamento de mais longo prazo, sem ser influenciado diretamente por flutuações específicas que podem ser observadas em um ano qualquer da projeção.

Portanto, para cada série de ENA há um resultado de $E T_{\text {SINb }}$, obtido pelo somatório das emissões correspondentes ao conjunto de usinas $u$ despachadas para atender a condição de equilíbrio entre a oferta e demanda de energia elétrica, ao longo do período considerado para a obtenção dos créditos de carbono.

Tendo em vista que, teoricamente, qualquer das 2000 séries de gerações das térmicas flexíveis pode ocorrer, embora um mesmo resultado possa ser obtido em distintas séries, optou-se no presente trabalho por distribuir os resultados, considerando como relevantes as emissões totais relacionadas com as seguintes estatísticas: mediana, média, $1^{\circ}$ e $3^{\circ}$ quartis, percentis 5 e 95, máximo e mínimo.

Em função da indisponibilidade de dados sobre o consumo de combustíveis das usinas térmicas despachadas no $\operatorname{SIN}$, a equação 7 , que é a $2^{2}$ opção sugerida no Capítulo 5 dessa proposta metodológica foi escolhida para determinar as emissões totais, sendo os volumes de combustíveis fósseis calculados com base em eficiências médias e tipo de combustível utilizado por cada usina para todas as 2000 séries de oferta térmica simuladas.

Adotou-se as eficiências médias indicada no Anexo 1 do Tool to calculate the emission factor for an eletricity system, versão 1, para as usinas planejadas. $\mathrm{Na}$ Tabela 26 são apresentados os fatores de emissão dos combustíveis fósseis usados nas usinas térmicas, calculados de acordo com as eficiências 
consideradas no presente trabalho para as usinas existentes no SIN e as usinas planejadas.

Tabela 26 - Fator de emissão ( $\left(\mathrm{tCO}_{2} / \mathrm{MWh}\right)$ por tipo de combustível

\begin{tabular}{lccccc}
\hline & & \multicolumn{2}{c}{ Usina Existente } & \multicolumn{2}{c}{ Usina Nova } \\
\hline \multicolumn{1}{c}{ Combustível } & Sigla & Eficiência & F Emissão & Eficiência & F Emissão \\
\hline Óleo Diesel & OD & 0,33 & 0,80 & 0,46 & 0,57 \\
Óleo Combustível & OC & 0,33 & 0,84 & 0,46 & 0,60 \\
Carvão Mineral & CM & 0,33 & 1,03 & 0,50 & 0,68 \\
Gás Natural Seco & GN e GNL & 0,50 & 0,40 & 0,60 & 0,33 \\
\hline
\end{tabular}

$\mathrm{FE}=$ Fator de Emissão em $\mathrm{tCO}_{2} / \mathrm{MWh}$

Então, aplicando a equação 2 do Capítulo 5, temos:

$E T_{S E b}=\sum_{u, y} G_{u y} \times F E_{u y}$

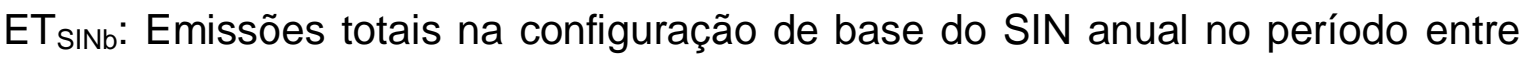
2008/2017;

$\mathrm{G}_{\text {uy: }}$ : Geração térmica anual de cada usina flexível despachada para atender as necessidades de complementação energética do SIN, para todas as soluções de equilíbrio simuladas no período entre 2008/2017;

$\mathrm{FE}_{\mathrm{uy}}$ : Fator de Emissão da usina u no ano y $\left(\mathrm{tCO}_{2} / \mathrm{MWh}\right)$, onde:

$\mathrm{FE}_{\mathrm{uy}}=\frac{\mathrm{FE}_{\mathrm{CO}_{2} \text { iuy }} \times 3,6}{\eta_{\mathrm{uy}}}$ 
$\mathrm{Na}$ Tabela 27 as emissões anuais e acumuladas na configuração de base

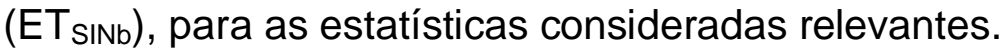

Tabela 27 - Emissões totais no SIN por ano e para todo o período $\left(\mathrm{ET}_{\mathrm{SINb}}\right.$ em milhões de $\mathrm{t} \mathrm{CO}_{2}$ )

\begin{tabular}{cccccccccccc}
\hline & $\begin{array}{c}2008- \\
2017\end{array}$ & 2008 & 2009 & 2010 & 2011 & 2012 & 2013 & 2014 & 2015 & 2016 & 2017 \\
\hline Mínimo & 125 & 4 & 2 & 2 & 2 & 3 & 2 & 3 & 4 & 4 & 11 \\
p05 & 177 & 7 & 4 & 5 & 5 & 9 & 11 & 11 & 13 & 17 & 24 \\
10 Quartil & 214 & 12 & 8 & 9 & 10 & 15 & 18 & 17 & 20 & 26 & 36 \\
Mediana & 244 & 17 & 11 & 13 & 14 & 20 & 24 & 23 & 26 & 34 & 46 \\
$3^{\circ}$ Quartil & 275 & 22 & 17 & 19 & 19 & 28 & 33 & 31 & 35 & 44 & 58 \\
p95 & 323 & 29 & 27 & 31 & 31 & 43 & 49 & 46 & 51 & 63 & 76 \\
Máximo & 414 & 32 & 47 & 60 & 63 & 73 & 90 & 78 & 89 & 87 & 91 \\
\hline Média & 246 & 17 & 13 & 15 & 16 & 23 & 26 & 25 & 28 & 36 & 48 \\
\hline
\end{tabular}

$\mathrm{Na}$ Tabela 28 os resultados dos fatores de emissões anuais, $\mathrm{tCO}_{2} / \mathrm{MWh}$, do $\mathrm{SIN}$, entre 2008-2017. O cálculo foi efetuado, considerando a energia gerada por todas as usinas térmicas flexíveis e as emissões a elas associadas, não incluindo o despacho das usinas de base.

Tabela 28 - Fatores de emissão no SIN por ano e para todo o período.

$\left(\mathrm{FE}_{\mathrm{SINb}}\right.$ em tCO $\left.\mathrm{tCO}_{2} / \mathrm{MWh}\right)$

\begin{tabular}{cccccccccccc}
\hline & $2008-$ & 2008 & 2009 & 2010 & 2011 & 2012 & 2013 & 2014 & 2015 & 2016 & 2017 \\
& 2017 & & & & & & & & & & \\
\hline Mínimo & 0,45 & 0,41 & 0,39 & 0,39 & 0,39 & 0,40 & 0,41 & 0,42 & 0,44 & 0,43 & 0,45 \\
p05 & 0,47 & 0,44 & 0,40 & 0,43 & 0,41 & 0,45 & 0,47 & 0,47 & 0,46 & 0,47 & 0,48 \\
$1^{\circ}$ Quartil & 0,47 & 0,47 & 0,43 & 0,45 & 0,44 & 0,47 & 0,48 & 0,48 & 0,48 & 0,49 & 0,50 \\
Mediana & 0,48 & 0,48 & 0,45 & 0,46 & 0,45 & 0,48 & 0,49 & 0,49 & 0,49 & 0,50 & 0,50 \\
$3^{\circ}$ Quartil & 0,48 & 0,49 & 0,46 & 0,47 & 0,46 & 0,49 & 0,50 & 0,50 & 0,50 & 0,50 & 0,52 \\
p95 & 0,49 & 0,51 & 0,48 & 0,49 & 0,48 & 0,50 & 0,50 & 0,50 & 0,51 & 0,52 & 0,53 \\
Máximo & 0,50 & 0,53 & 0,53 & 0,54 & 0,53 & 0,54 & 0,54 & 0,52 & 0,54 & 0,54 & 0,54 \\
\hline Média & 0,48 & 0,48 & 0,45 & 0,46 & 0,45 & 0,48 & 0,49 & 0,49 & 0,49 & 0,49 & 0,50 \\
\hline
\end{tabular}

Destaca-se que esse fator não representa as emissões que poderão ser deslocadas com a entrada das atividades de um projeto de MDL. Ele apenas expressa as emissões, por unidade de energia, relacionadas com o mix de termelétricas flexíveis que serão despachadas ao longo do período de obtenção 
de crédito, de acordo com as simulações realizadas pelo modelo. O Fator de Emissão do SIN na configuração de base é dado por:

$F E_{S E_{b}}=\frac{E T_{S E b}}{G T_{S E b}}$, onde:

$F E_{\text {SEb }}=$ Fator de emissão da configuração de base

$\mathrm{ET}_{\mathrm{SEb}}=$ Total de emissões associadas aos conjuntos $m$ identificados para cada solução de equilíbrio da configuração de base

$\mathrm{GT}_{\mathrm{SEb}}=$ Geração total das usinas flexíveis que serve ao sistema elétrico, sendo:

$G T_{S E b}=\sum_{u, y} G_{u y}$, onde:

$u=$ todas as usinas que pertencem aos conjuntos $m$ da configuração de base y = cada ano do período definido para obtenção de créditos de carbono

6.2.4 Cálculo do Fator de Substituição do período $\left(F S_{S I N p}\right)$ e anual $\left(F S_{S I N y}\right)$ para os experimentos realizados

Definição da energia a ser deslocada SIN com a entrada do projeto

De acordo com a proposta metodológica apresentada no Capítulo 5 do presente trabalho, o fator de substituição de um projeto candidato ao MDL a ser conectado em sistema elétrico, deve ser estimado considerando a energia que provavelmente será deslocada com a conexão desse projeto à rede elétrica. Para tanto, é necessário estabelecer quanto da eletricidade fornecida pelo mix das 
fontes energéticas que servem ao sistema será substituída com a entrada desse projeto.

Para determinar o Fator de Substituição de um projeto elegível como MDL definese, em primeiro lugar, a quantidade de energia que o projeto candidato ao MDL é capaz de substituir e/ou economizar. No presente trabalho foram realizados três grupos de experimentos para simular diferentes entradas de gerações de usinas não emissoras ou reduções de demanda no SIN.

Mais adiante, no item 6.3 deste Capítulo, são descritos esses grupos de experimentos e apresentados os resultados encontrados.

6.2.4.1 Determinação da energia gerada na configuração final

Re-simulação do equilíbrio entre oferta e demanda por energia elétrica e determinação das energias geradas (MWh), conforme procedimentos descritos no passo 3.

Para cada nova configuração são determinadas as emissões totais, a partir das novas gerações das usinas térmicas flexíveis re-simuladas pelo modelo, considerando a variação de capacidade resultante da entrada/redução da energia associada ao projeto MDL.

\subsubsection{Cálculo dos Fatores de Substituição dos Experimentos}

Considerando que a mesma série de ENA foi utilizada para definir o despacho das usinas térmicas nas configurações de base e nas novas configurações ou configurações finais, então por diferença calculam-se as emissões deslocadas com a entrada das atividades do projeto. Estas, divididas pela capacidade de 
geração do projeto fornecem o fator de substituição anual e o fator de substituição agregado para todo o período considerado, $\mathrm{FS}_{\mathrm{SINy}}$ ou $\mathrm{FS}_{\mathrm{SINp}}$, respectivamente.

6.2.4.3 Distribuição dos Fatores de Substituição dos Experimentos

Nessa etapa é realizada a distribuição das probabilidades dos fatores de substituição encontrados de cada experimento para as estatísticas consideradas relevantes, a saber: mediana, média, máximo, mínimo, $1^{\circ}$ e $3^{\circ}$ quartis e percentis 5 e 95.

Como acima destacado, dado que cada série de despacho é função de uma série específica de ENA tanto para a configuração de base como para a configuração final, então se calcula, primeiramente, a diferença das emissões totais entre as duas configurações para em seguida distribuir os resultados dos fatores de substituição encontrados.

\subsection{Apresentação dos Grupos de Experimentos e Resultados}

No presente estudo de caso foram realizados 12 experimentos agrupados em três grupos para determinar o fator de substituição, ou linha de base, associado a um projeto MDL para diferentes quantidades de energias deslocadas, tendo como referência as emissões calculadas para a configuração de base.

Observe-se que para todos os experimentos pressupõe-se que a energia gerada com as atividades do projeto MDL seja despachada na base ou, alternativamente, se as atividades do projeto MDL se referem a medidas ou programas de eficiência energética pelo lado da demanda pela redução equivalente dos requisitos de energia do SIN. 
Assim, como o despacho flexível das usinas térmicas convencionais só ocorre, por ordem de mérito, após terem se esgotado todos os recursos hidrotérmicos despachados na base, a entrada do projeto ou a redução dos requisitos de energia deslocará a energia que seria despachada pela térmica convencional com preço mais elevado na ausência do projeto MDL.

\subsubsection{Descrição dos grupos de experimentos}

Grupo 1: Fatores de Substituição calculados para diferentes quantidades de eletricidade deslocadas com a entrada do projeto MDL, sem considerar a entrada do programa de eficiência energética planejado no PDE 2007-2016 para entrar em 2011, na configuração de base.

> Escopo do projeto: energias renováveis não emissoras/projetos de eficiência energética pelo lado da demanda, exceto para energia gerada por usina nuclear, conectados ao SIN;

Ano de entrada do projeto MDL: 2008, primeiro ano do período de obtenção de crédito de carbono;

> Configuração de base: fixa, sem incorporação da entrada do projeto MDL nos anos subseqüentes;

> Projeção dos requisitos do SIN: trajetória inferior do PDEE 2007-2016, com demanda para 2017, projetada com base na taxa de crescimento estimada entre 2016-2015;

> Energia deslocada pelo projeto em MW médios para cada experimento: $50,500,1000,5000,15000$ e 25000 ;

> Distribuição dos resultados para as estatísticas consideradas relevantes: mediana, média, percentis 5 e 95, $1^{\circ}$ e $3^{\circ}$ quartis, máximo e mínimo. 
Grupo 2: Fatores de Substituição calculados para diferentes quantidades de eletricidade deslocadas pelas atividades do projeto $\mathrm{MDL}$, considerando a entrada de parte do programa de eficiência energética planejado no PDE 2007-2016 para 2011 ${ }^{101}$. No experimento considerou-se que $350 \mathrm{MW}$ médios poderiam ser economizados de forma induzida por atividades de projetos de eficiência energética pelo lado da demanda, elegíveis como MDL.

> Escopo do projeto: energias renováveis não emissoras/ projetos de eficiência energética pelo lado da demanda, exceto para energia gerada por usina nuclear, conectados ao SIN;

Ano de entrada do projeto MDL: 2008, primeiro ano do período de obtenção de crédito de carbono;

Configuração de base: fixa, sem incorporação da entrada do projeto MDL nos anos subseqüentes;

Projeção dos requisitos do SIN: trajetória inferior do PDEE 2007-2016, com demanda para 2017, projetada com base na taxa de crescimento estimada entre 2016-2015;

D Energia deslocada pelo projeto em MW médios: 50, 500, 1000;

- A partir de 2011 soma-se à energia deslocada pelo projeto MDL a redução dos requisitos de energia provocada pelo programa de eficiência energética pelo lado da demanda de $350 \mathrm{MW}$ médios;

Distribuição dos resultados para as estatísticas consideradas relevantes: mediana, média, percentis 5 e 95, $1^{\circ}$ e $3^{\circ}$ quartis, máximo e mínimo.

101 - O Programa de Eficiência Energética do PDE 2007-2016 prevê uma redução nos requisitos de energia de, aproximadamente, $500 \mathrm{MW}$ médios a partir de 2011, porém considera 0 resultado combinado da eficientização autônoma e induzida. 
Grupo 3: Fatores de Substituição calculados, considerando apenas a entrada de projetos de eficiência energética a partir de 2011.

> Escopo do projeto: projetos de eficiência energética pelo lado da demanda;

Ano de entrada do projeto MDL: 2011, primeiro ano do período de obtenção de crédito de carbono;

Configuração de base: fixa, sem incorporação da entrada do projeto MDL nos anos subseqüentes;

> Projeção dos requisitos do SIN: trajetória inferior do PDEE 2007-2016, com demanda para 2017, projetada com base na taxa de crescimento estimada entre 2016-2015;

Energia deslocada pelo projeto em MW médios: 250, 350, 500;

Distribuição dos resultados para as estatísticas consideradas relevantes: mediana, média, percentis 5 e 95, $1^{\circ}$ e $3^{\circ}$ quartis, máximo e mínimo. 


\subsubsection{Resultados Encontrados}

Nas Tabelas 29 e 30 e Gráficos 21, 22, 23 e 24 os resultados dos experimentos do Grupo 1

Tabela 29 - Fator de substituição no período $\left(\mathrm{FS}_{\mathrm{SINp}}\right)$ - $\mathrm{t} \mathrm{CO}_{2} / \mathrm{MWh}$ - Grupo 1

\begin{tabular}{ccccccc}
\hline \multirow{2}{*}{ FS SINp } & \multicolumn{7}{c}{ Grupo 1 } \\
\cline { 2 - 7 } & 50 & 500 & 1000 & 5000 & 15000 & 25000 \\
\hline Mínimo & 0,14 & 0,13 & 0,14 & 0,11 & 0,07 & 0,05 \\
p05 & 0,19 & 0,19 & 0,19 & 0,16 & 0,10 & 0,07 \\
$1^{\circ}$ Q Quartil & 0,23 & 0,23 & 0,23 & 0,19 & 0,12 & 0,09 \\
Mediana & 0,27 & 0,27 & 0,26 & 0,22 & 0,14 & 0,10 \\
3o Quartil & 0,31 & 0,30 & 0,29 & 0,25 & 0,16 & 0,11 \\
p95 & 0,36 & 0,34 & 0,34 & 0,29 & 0,19 & 0,13 \\
Máximo & 0,44 & 0,42 & 0,41 & 0,36 & 0,25 & 0,17 \\
Média & 0,27 & 0,27 & 0,26 & 0,22 & 0,14 & 0,10 \\
\hline
\end{tabular}

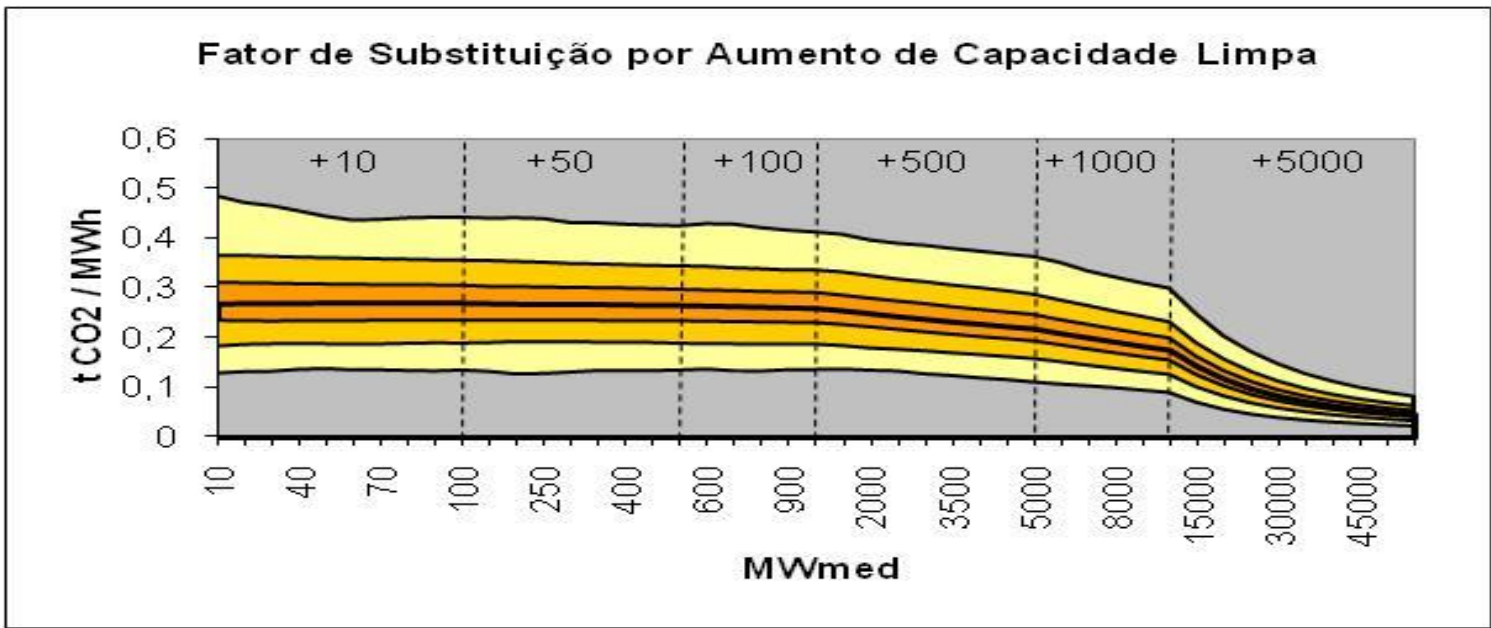

Gráfico 21 - Comportamento do fator de substituição por aumento de capacidade limpa 
Tabela 30 - Fator de substituição anual $\left(\mathrm{FS}_{\mathrm{SINy}}\right)$ t $\mathrm{CO}_{2} / \mathrm{MWh}$ - mediana - Grupo 1

\begin{tabular}{c|ccccccccccc}
\hline \multicolumn{2}{c}{ Experimento } & 2008 & 2009 & 2010 & 2011 & 2012 & 2013 & 2014 & 2015 & 2016 & 2017 \\
\hline- & 50 & 0,14 & 0,17 & 0,20 & 0,19 & 0,26 & 0,29 & 0,26 & 0,27 & 0,32 & 0,37 \\
\hline & 500 & 0,16 & 0,18 & 0,19 & 0,19 & 0,25 & 0,28 & 0,26 & 0,27 & 0,32 & 0,37 \\
을 & 000 & 0,16 & 0,17 & 0,18 & 0,18 & 0,24 & 0,27 & 0,25 & 0,26 & 0,31 & 0,37 \\
\hline
\end{tabular}

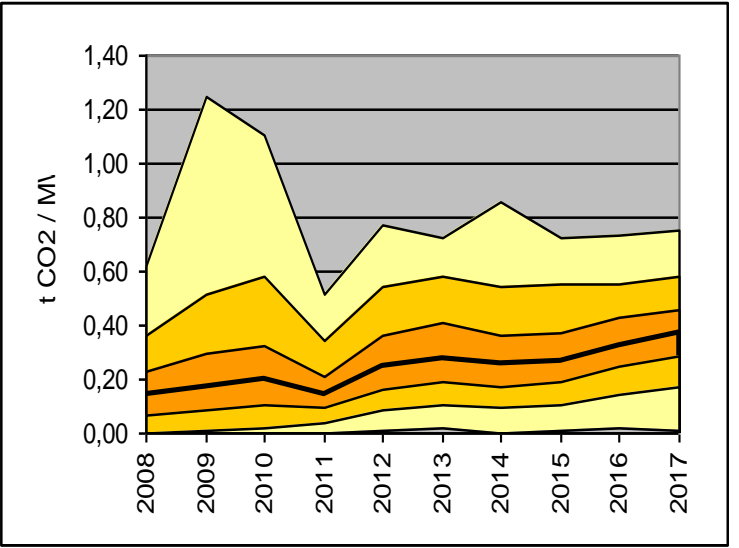

Gráfico 22- Grupo 1: Usina 50 MW FS $S_{\text {SINy }}$

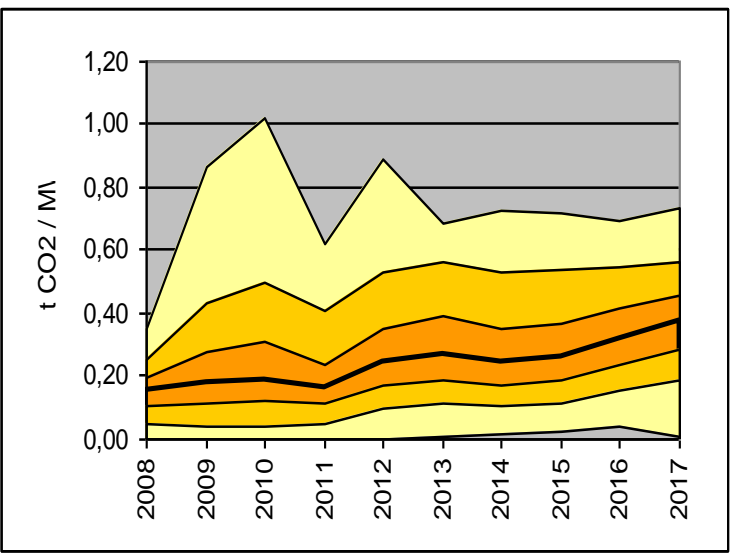

Gráfico 23 - Grupo 1: Usina 500 MW FS SINy

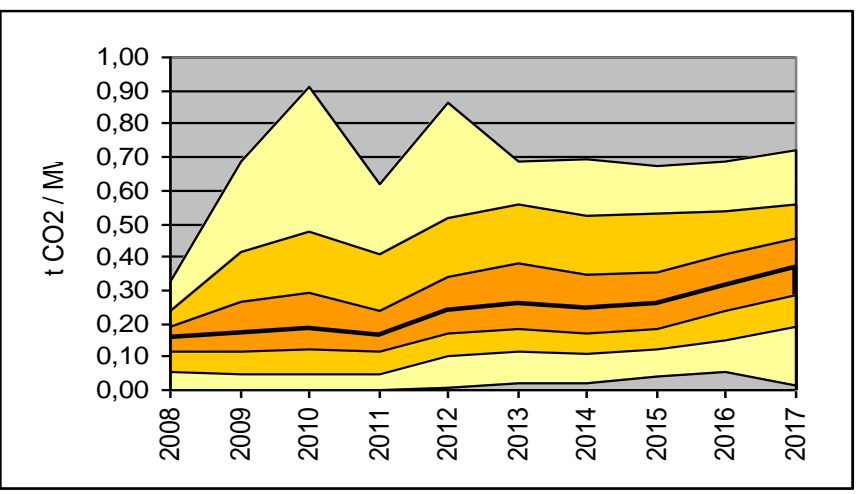

Gráfico 24 - Grupo 1: Usina1000 MW FS SINy 
Nas Tabelas 31 e 32 e Gráficos 25, 26 e 27 os resultados dos experimentos do Grupo 2

Tabela 31 - Fator de substituição período $\left(\mathrm{FS}_{\mathrm{SINp}}\right)-\mathrm{t} \mathrm{CO}_{2} / \mathrm{MWh}$ - Grupo 2

\begin{tabular}{cccc}
\hline FS SINp & \multicolumn{3}{c}{ Grupo 2} \\
& 50 & 500 & 1000 \\
\hline Mínimo & 0,13 & 0,13 & 0,14 \\
p05 & 0,19 & 0,19 & 0,18 \\
1ํ Quartil & 0,23 & 0,23 & 0,23 \\
Mediana & 0,26 & 0,26 & 0,26 \\
3o Quartil & 0,29 & 0,29 & 0,29 \\
p95 & 0,34 & 0,34 & 0,33 \\
Máximo & 0,41 & 0,41 & 0,40 \\
Média & 0,26 & 0,26 & 0,26 \\
\hline
\end{tabular}

Tabela 32 - Fator de substituição anual $\left(\mathrm{FS}_{\mathrm{SINy}}\right)$ t $\mathrm{CO}_{2} / \mathrm{MWh}$ - mediana - Grupo 2

\begin{tabular}{c|ccccccccccc}
\hline \multicolumn{2}{c}{ Experimento } & 2008 & 2009 & 2010 & 2011 & 2012 & 2013 & 2014 & 2015 & 2016 & 2017 \\
\hline \multirow{N}{*}{} & 50 & 0,14 & 0,17 & 0,20 & 0,15 & 0,25 & 0,28 & 0,26 & 0,27 & 0,33 & 0,37 \\
$\stackrel{\circ}{ }$ & 500 & 0,16 & 0,18 & 0,19 & 0,16 & 0,24 & 0,27 & 0,25 & 0,26 & 0,32 & 0,37 \\
$\stackrel{ }{ }$ & 1000 & 0,16 & 0,17 & 0,18 & 0,16 & 0,24 & 0,26 & 0,24 & 0,26 & 0,32 & 0,37 \\
\hline
\end{tabular}

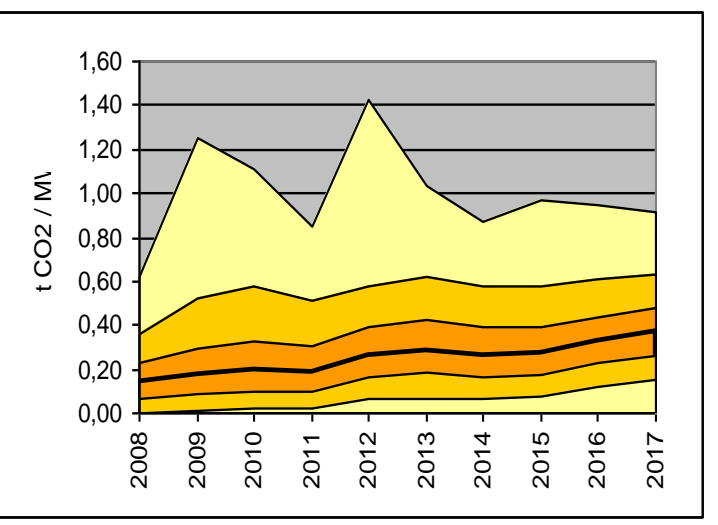

Gráfico 25- Grupo 2: Usina 50 MW FS

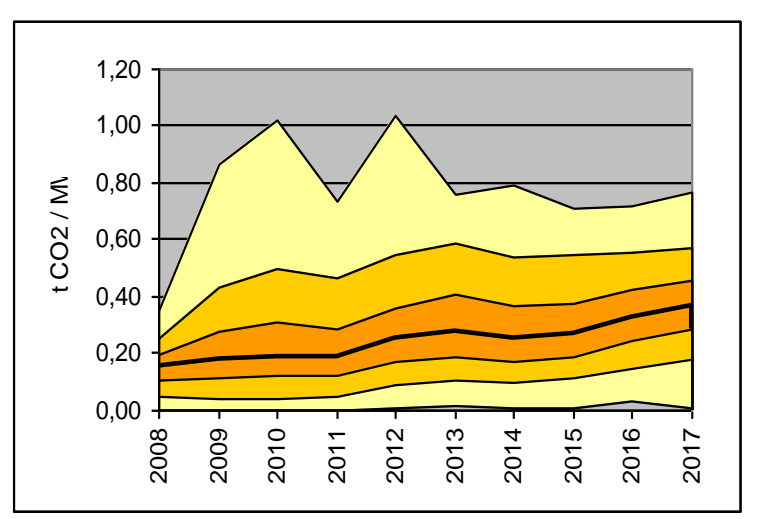

Gráfico 26 - Grupo 2:Usina 500 MW FS 


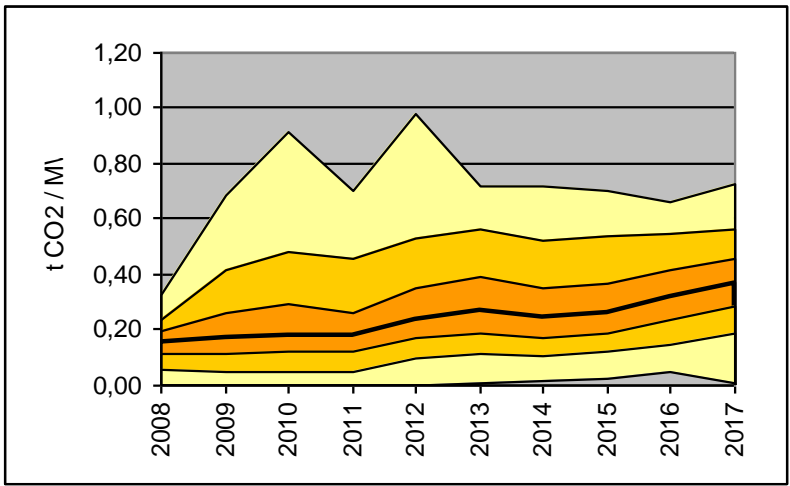

Gráfico 27- Grupo 2: Usina1000 MW FS SINy $_{1}$

Nas Tabelas 33 e 34 e Gráficos 28, 29, e 30 os resultados dos experimentos do Grupo 3

Tabela 33 - Fator de substituição período $\left(\mathrm{FS}_{\mathrm{SINp}}\right)-\mathrm{t} \mathrm{CO}_{2} / \mathrm{MWh}$ - Grupo 3

\begin{tabular}{cccc}
\hline FS SINp & \multicolumn{3}{c}{ Grupo 3 } \\
& 250 & 350 & 500 \\
\hline Mínimo & 0,10 & 0,11 & 0,12 \\
p05 & 0,20 & 0,20 & 0,20 \\
1ㅇ Quartil & 0,25 & 0,25 & 0,25 \\
Mediana & 0,29 & 0,29 & 0,29 \\
3 Quartil & 0,33 & 0,33 & 0,32 \\
p95 & 0,38 & 0,38 & 0,38 \\
Máximo & 0,54 & 0,54 & 0,53 \\
Média & 0,29 & 0,29 & 0,29 \\
\hline
\end{tabular}

Tabela 34 - Fator de substituição anual $\left(\mathrm{FS}_{\mathrm{SINy}}\right)$ t $\mathrm{CO}_{2} / \mathrm{MWh}$ - mediana - Grupo 3

\begin{tabular}{|c|c|c|c|c|c|c|c|c|c|c|c|}
\hline \multicolumn{2}{|c|}{ Experimento } & 2008 & 2009 & 2010 & 2011 & 2012 & 2013 & 2014 & 2015 & 2016 & 2017 \\
\hline$m$ & 250 & 0 & 0 & 0 & 0,14 & 0,25 & 0,29 & 0,26 & 0,27 & 0,33 & 0,37 \\
\hline 옥 & 350 & 0 & 0 & 0 & 0,14 & 0,25 & 0,28 & 0,26 & 0,27 & 0,33 & 0,37 \\
\hline তั & 500 & 0 & 0 & 0 & 0,14 & 0,25 & 0,28 & 0,25 & 0,27 & 0,32 & 0,37 \\
\hline
\end{tabular}




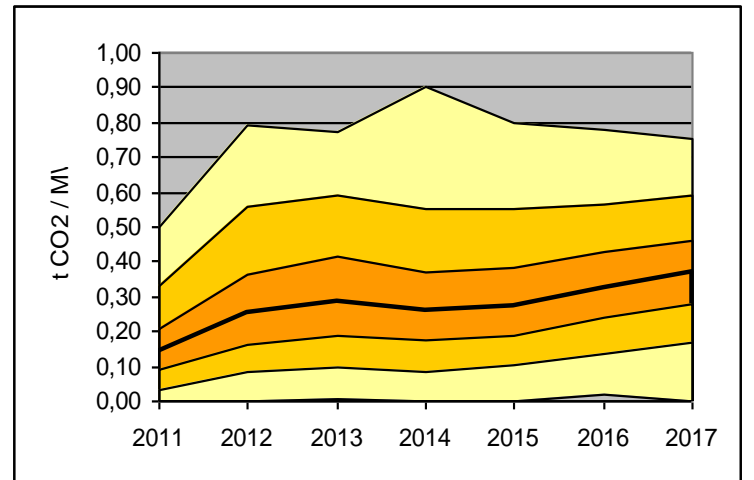

Gráfico 28- Grupo 3: Usina 50 MW FS $S_{\text {SINy }}$

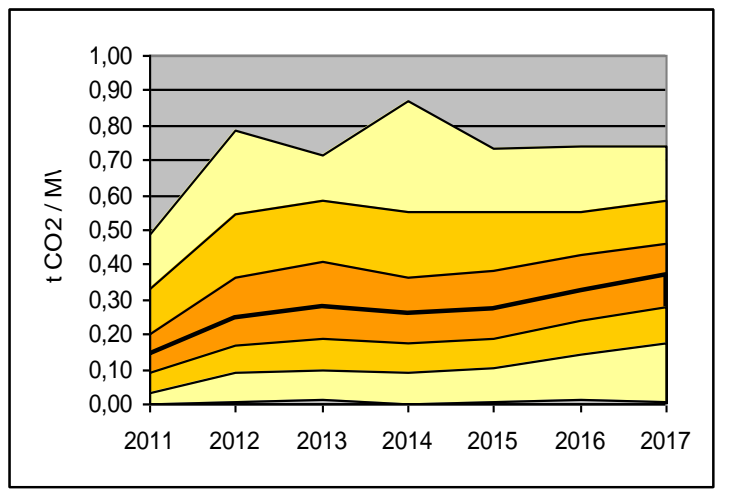

Gráfico 29- Grupo 3:Usina 500 MW FS

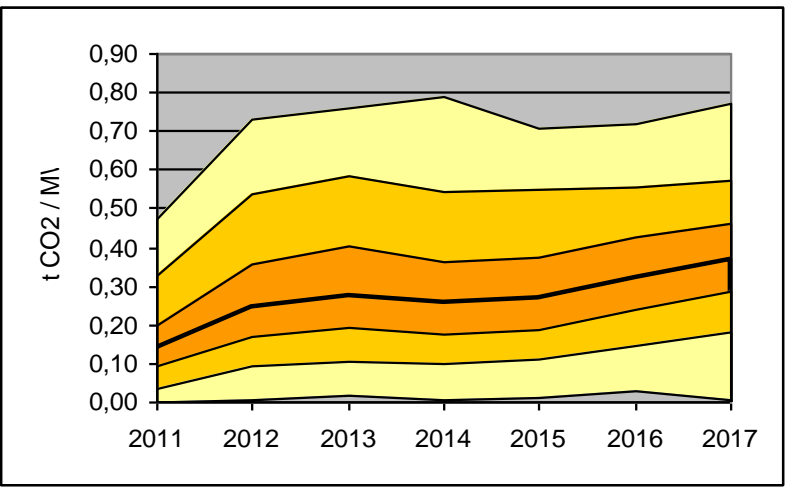

Gráfico 30- Grupo 3:Usina1000 MW FS

\subsubsection{Discussão dos Resultados}

Os resultados confirmam a tendência de aumento das emissões do SIN ao longo do período estudado. Entre 2008 e 2017 as emissões de $\mathrm{CO}_{2}$ serão duas vezes e meia maiores, refletindo as elevações previstas dos despachos das termelétricas convencionais. Nesse período, de acordo com os resultados simulados para a mediana, as emissões crescerão $170 \%$, passando de 17 milhões de $\mathrm{tCO}_{2}$ estimadas para 2008 para 46 milhões de $\mathrm{tCO}_{2}$ em 2017.

Para todos os experimentos observou-se uma grande amplitude entre os fatores de substituição máximos e mínimos, refletindo a variabilidade das ENA e o custo de oportunidade da água armazenada nos reservatórios. A distribuição dos 
resultados, que se encontram nas Tabelas 29, 31 e 33 mostram que os FS SINp variam consideravelmente, sendo que na maioria dos experimentos os fatores máximos são três vezes superiores aos valores mínimos encontrados.

Considerando as premissas adotadas na metodologia aqui proposta, apenas 0 fator de substituição estimado para todo o período de crédito $\left(\mathrm{FS}_{\mathrm{SINp}}\right)$ deve ser levado em conta para estimar a linha de base de um projeto candidato ao MDL, tendo em vista que o fator de substituição anual ( FS $\left._{\text {SINy }}\right)$ é bastante susceptível ao comportamento de algumas variáveis de entrada que, com freqüência, sofrem importantes alterações, em curto prazo, com destaque para a variabilidade da ENA.

Apesar disso, o cálculo do fator de emissão anual é muito importante porque por meio dele torna-se possível, além de identificar e quantificar, razoavelmente, essas oscilações de curto prazo, balizar melhor a decisão do proponente sobre a implementação do projeto MDL.

A estimativa dos fatores de emissão anuais estimados ( $\mathrm{FS}_{\mathrm{SINy}}$ ), para os três grupos de experimentos, mostrou que nem sempre um ano mais emissor, corresponde a um fator de substituição mais elevado. Com efeito, os fatores de substituição anuais para todos os experimentos, Tabelas 30,32 e 34 se mostraram sensíveis às variações em relação ao tamanho do projeto, ao volume inicial de água armazenado nos reservatórios e as ENA do período.

Curiosamente, no entanto, quanto menor o nível da água armazenada no início de cada ano menor também será o fator de substituição e vice-versa. O fator de substituição anual $\mathrm{FS}_{\mathrm{SINy}}$ será máximo quando o nível dos reservatórios for médio. Para elaborar esta análise foram considerados os níveis conforme descritos na Figura 6, que representa, grosso modo, esse movimento entre substituição de $\mathrm{CO}_{2}$ e o nível do reservatório. 


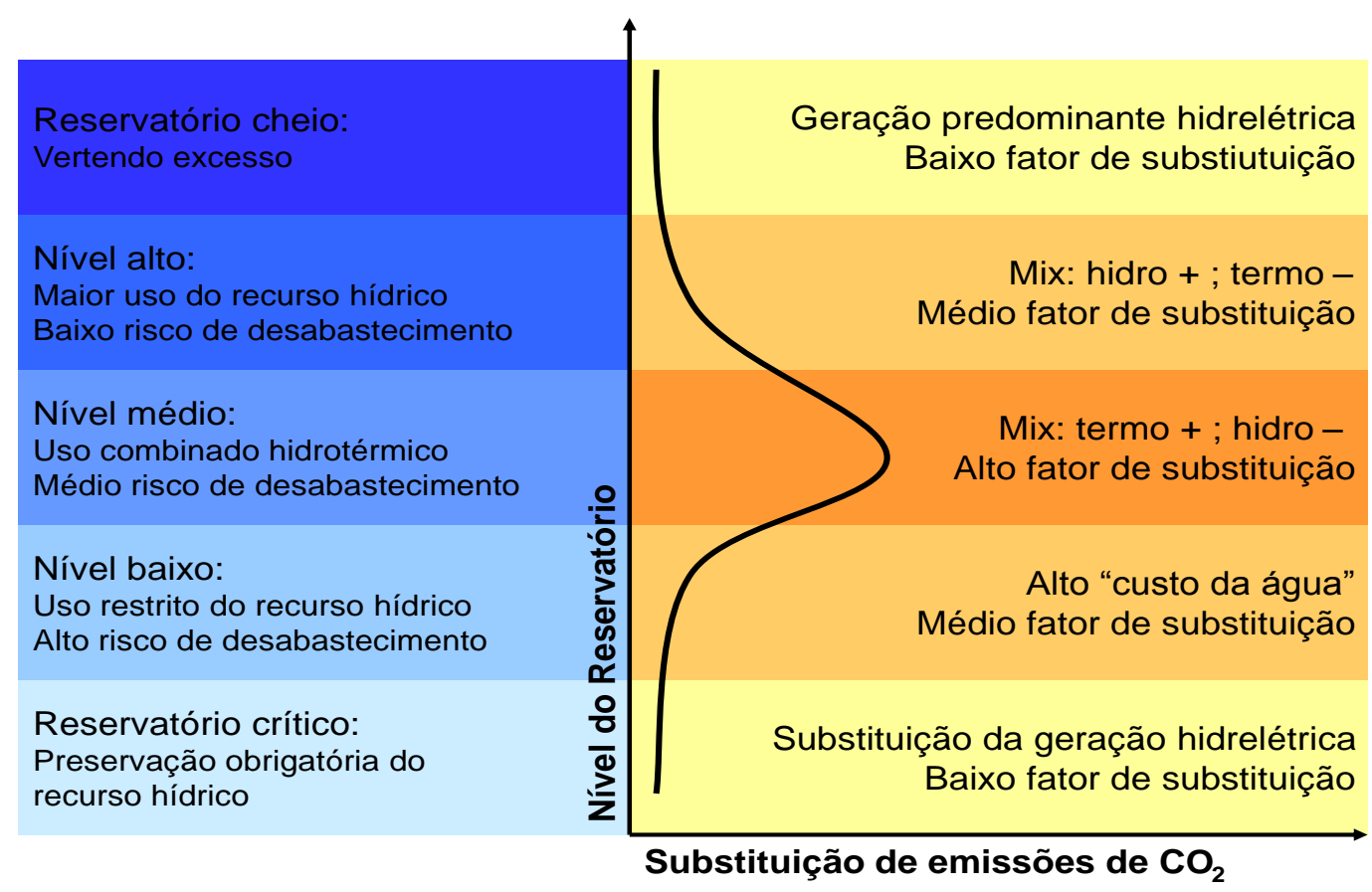

Figura 6 - Substituição de emissões de $\mathrm{CO}_{2}$ entre um projeto MDL e o nível do reservatório equivalente

Isso ocorre pelas seguintes razões:

1- Quando os reservatórios se encontram em situação muito crítica ou com níveis baixos de armazenamento de água, o modelo, simulando uma decisão racional do operador do sistema, entende que é necessário preservar água e despacha as usinas térmicas, independentemente do seu preço porque o custo do déficit é, em geral, superior ao custo de despacho de uma central térmica cara;

2- Em conseqüência, a entrada de uma usina não emissora na base e/ou a redução da demanda agregada resultante de medidas de eficiência energética, não alteram a decisão indicada pelo modelo, na medida em que para garantir a segurança do fornecimento ele "prefere" continuar despachando as usinas térmicas. Portanto, o fator de substituição é baixo ou não existe nenhuma substituição porque simplesmente o projeto de MDL não é capaz de deslocar usinas emissoras dos GEE. 
3- Se ao contrário, os reservatórios estão vertendo ou estão cheios a decisão simulada pelo modelo é despachar usinas hidrelétricas, deixando de utilizar as centrais térmicas flexíveis. Nessas condições, da mesma forma que na situação anterior, a entrada de uma usina não emissora na base e/ou a redução da demanda agregada resultante de medidas de eficiência energética, não alteram a decisão pela manutenção pelo despacho de apenas usinas hidrelétricas ${ }^{102}$. Ora, se isso de fato ocorrer então, da mesma forma que na situação anterior, não haverá redução de emissões porque o projeto de MDL efetivamente não desloca nenhuma usina emissora dos GEE.

4- Nas situações em que os reservatórios se encontram em níveis médios (nem muito cheios nem muito vazios) o fator de substituição tende a subir ou é máximo porque a esse nível de água armazenada, há despacho de térmicas flexíveis e a entrada de projetos de MDL podem, efetivamente, alterar o mix das fontes energéticas que servem ao sistema naquele dado momento.

Essa análise mostra e reforça o argumento de que a determinação dos fatores de substituição anuais é insuficiente e poderá induzir a erros quando se trata de decidir sobre o desenvolvimento e implementação de projeto(s) programa(s) elegíveis como MDL. Com efeito, um fator de substituição baixo em um ano poderá não sê-lo no ano seguinte. Para superar parcialmente as incertezas tornase fundamental considerar todo o período de crédito e não apenas um ano.

Nesse sentido, cumpre destacar o despacho das centrais termelétricas flexíveis pelo ONS, em 2008, em função dos níveis críticos dos reservatórios observados a partir do $3^{\circ}$ trimestre de 2007 . Muito provavelmente, qualquer projeto elegível como MDL não iria alterar a decisão do operador nacional em relação à magnitude do despacho das térmicas flexíveis, em face à percepção do risco de desabastecimento. A determinação dos fatores em nível anual deve servir apenas para informar ao agente que vai decidir a implementação do projeto MDL sobre a magnitude e as variações dos fluxos de caixa anuais esperados com as receitas do MDL.

102 - Exceto para o despacho das térmicas inflexíveis cujos critérios de utilização não obedecem a essa lógica. 
Por outro lado, como no SIN, a entrada de um projeto MDL desloca tanto a energia oriunda das centrais térmicas como usinas hidrelétricas, uma parte da energia deslocada, ou seja, aquela parte oriunda das hidrelétricas para as quais se consideram emissões zero ${ }^{103}$ contribui para que a linha de base dos projetos conectados ao SIN seja sempre inferior ao valor médio ponderado das emissões associadas às energias comercializadas pelas usinas termelétricas convencionais nos leilões de energia nova.

Isso ocorre porque eles refletem o mix das fontes energéticas despachadas pelo $\mathrm{ONS}^{104}$ que é efetivamente deslocado com a entrada do projeto MDL e não a capacidade instalada e a energia que, potencialmente, essas centrais térmicas podem gerar. Esse é um aspecto importante porque para projetos de MDL, o que conta não é o quanto o conjunto das usinas termelétricas está emitindo ou o seu potencial de emissões, mas sim o que de fato o projeto desloca com a entrada em operação das suas atividades.

Para os experimentos realizados (Grupos 1, 2 e 3) os resultados mostram que os fatores de substituição do período ( $\left.\mathrm{FS}_{\mathrm{SINp}}\right)$, para todas as estatísticas, variam em função do tamanho do projeto MDL. Quanto maior o projeto menor será o fator de substituição (Tabela 31).

Essas diferenças do valor apurado para o $\mathrm{FS}_{\text {SINp }}$ são quase imperceptíveis ou muito pequenas para programas/projetos até 1.000 MW médios. Entre $1.000 \mathrm{e}$ $5.000 \mathrm{MW}$ médios, os $\mathrm{FS}_{\mathrm{SINp}}$ caem progressivamente até atingir valores muito baixos para programas/projetos acima de $10.000 \mathrm{MW}$ médios. No Gráfico 21 as curvas que mostram o comportamento da relação entre o tamanho dos projetos e os fatores de substituição associados.

\footnotetext{
103 - Destaque-se que essa consideração de emissões zero não significa que as hidrelétricas não emitam GEE, mas apenas que foi assumida a premissa adotada de emissões zero para a energia gerada por hidrelétricas. Estudos conduzidos por SANTOS, M.A., PINGUELLI, L.R., et.al (2008) e FEARNSIDE, P. M. (2005) mostram que as hidrelétricas emitem GEE, ainda que não haja consenso entre os autores dessas pesquisas em relação às metodologias de contabilização aplicadas.

${ }_{104}$ - Calculado mensalmente pelo modelo MEI e agregado, para a obtenção dos resultados no presente trabalho, em nível anual.
} 
Esse comportamento era esperado, na medida em que, sendo a base hidrelétrica do SIN extremamente elevada, com mais de $77 \%$ da energia elétrica ofertada oriunda das usinas hidrelétricas, quanto maior o projeto de MDL conectado maior será a participação da energia de origem hídrica no mix energético a ser substituído pelas atividades do projeto MDL.

Os experimentos associados ao Grupo 3, Tabelas 33 e 34 apresentam fatores de substituição, para todo o período e anuais, $\mathrm{FS}_{\mathrm{SINp}}$ e $\mathrm{FS}_{\mathrm{SINy}}$, respectivamente superiores àqueles encontrados para os experimentos dos Grupos 1 e 2. Isso ocorre porque a premissa adotada para os experimentos do Grupo 3, foi de que apenas em 2011 os projetos de MDL fossem implementados, ou seja, até aquela data nenhuma central térmica movida à energia renovável e/ou programa de medidas de eficiência energética entraria no sistema elétrico deslocando usinas térmicas emissoras ou, se entrassem, a oferta adicional seria tão pequena que não afetaria a composição do mix das fontes energéticas com ordem de mérito mais elevado.

Os valores da mediana encontrados para os $\mathrm{FS}_{\mathrm{SINp}}$ de $0,27 \mathrm{tCO}_{2} / \mathrm{MWh}$, 0,26tCO $2 / \mathrm{MWh}$ e 0,29tCO$/ \mathrm{CO}_{2} / \mathrm{MWh}$ para os experimentos dos Grupos 1, 2 e 3, respectivamente mostraram-se compatíveis com resultados encontrados em trabalhos (Esparta, 2008; Soliano, et al., 2006; CIMGC, 2007 e MMA/PNMC, 2008) que utilizaram metodologias diferentes da proposta metodológica desenvolvida nessa pesquisa.

De acordo com Esparta $(2008)^{105}$, o fator de emissão do SIN foi estimado em $0,23 \mathrm{tCO}_{2} / \mathrm{MWh}$. O autor chama a atenção para o fato de que essa estimativa ainda é muito baixa, e bastante influenciada pelo fator da margem de construção, que foi calculado de forma muito conservadora.

\footnotetext{
105 - Esparta propôs uma nova metodologia (NM 0051) para calcular o fator de emissão do SIN. De acordo com o autor, a proposta foi informalmente aprovada pelo Painel de Metodologia, em 2004, como indicação de que seria incorporada à metodologia consolidada aprovadas ACM 002 (METH-PANEL, 2004), porém até o final de 2007 essa incorporação não havia sido concretizada.
} 
Soliano, et al., (2006) estimou o fator de emissão do $\operatorname{SIN}$ em $0,27 \mathrm{tCO}_{2} / \mathrm{MWh}$, aplicando o método de cálculo simples ajustado da margem de operação, método $b$, preconizado na metodologia ACM 0002.

De acordo com a CIMGC, que aplicou o método de cálculo da análise dos dados do despacho, método $c$, do Tool to calculate the emission factor for na electricity system, os seguintes resultados foram encontrados: 0,20 tCO $/ \mathrm{MWh}$ em 2006 e $0,18 \mathrm{tCO}_{2} / \mathrm{MWh}$, em 2007. O fator de emissão do SIN para 2008 ainda não foi divulgado. No entanto, como os fatores de emissão para a margem operacional foram calculados e divulgados, com média anual de $0,48 \mathrm{tCO}_{2} / \mathrm{MWh}$ e, considerando que a margem operacional será, no mínimo igual àquela calculada para 2007 de $0,08 \mathrm{tCO}_{2} / \mathrm{MWh}$, o fator de emissão do SIN não será inferior a 0,28 $\mathrm{tCO}_{2} / \mathrm{MWh}$. Tomando a média dos três anos (2006-2008) o fator de emissão do $\mathrm{SIN}$ calculado é da ordem de $0,22 \mathrm{tCO} / \mathrm{MWh}$.

Observe-se que essa média, $0,22 \mathrm{tCO}_{2} / \mathrm{MWh}$, é praticamente igual aos fatores de substituição ( $\mathrm{FS}_{\mathrm{SINp}}$ ) encontrados para o $1^{\circ}$ quartil, de 0,23 $\mathrm{tCO}_{2} / \mathrm{MWh}$, para todos os experimentos com projetos de MDL com até $1.000 \mathrm{MW}$ médios de energia deslocada (Tabelas 29 e 31 ). Além disso, os resultados dos $\mathrm{FS}_{\text {SINp }}$ do $3^{\circ}$ quartil, de $0,30 \mathrm{tCO}_{2} / \mathrm{MWh}$, (Tabelas 29 e 31) aproximam-se ao fator esperado para o SIN em 2008, calculado pelo MCT que, conforme acima mencionado, não será inferior a $0,28 \mathrm{tCO}_{2} / \mathrm{MWh}$.

O fator de emissão de $0,29 \mathrm{tCO}_{2} / \mathrm{MWh}$, foi assumido pelo PNMC (MMA, 2008a) para calcular o potencial de emissões que poderiam ser evitadas no setor elétrico brasileiro, em função de iniciativas relacionadas com a redução das emissões dos GEE nessa área ${ }^{106}$.

A vantagem da adoção de uma abordagem metodológica tal como essa apresentada no presente trabalho é que ela ao incorporar ao processo de cálculo

\footnotetext{
106 - De acordo com o Plano Nacional de Mudança do Clima "os cálculos referentes ao potencial de mitigação das ações do setor elétrico previstas no presente Plano utilizam um fator de emissão único para o $\mathrm{SIN}$, de $0,29 \mathrm{tCO}_{2} / \mathrm{MWh}$, o mesmo dos projetos MDL no ano de 2008 “ (PNMC, 2008, p.30)
} 
uma projeção das emissões do SIN, oferece ao proponente do projeto de MDL a ser conectado ao sistema elétrico, maior segurança sobre o comportamento futuro do fator de emissão, na medida em que eles podem ser estimados, com o uso de modelos de simulação relativamente simples, utilizando os dados e informações adotados no planejamento da expansão do sistema elétrico. Isso é importante porque em sistema elétrico com as características do SIN, qualquer entendimento baseado no curto prazo, ou no histórico das emissões, fatalmente, subestimará ou será levado a superestimar o despacho futuro das térmicas convencionais flexíveis.

Por outro lado, como o sistema elétrico nacional passa por grandes mudanças na sua matriz energética, com a elevação da participação das fontes térmicas convencionais emissoras dos GEE, a avaliação do comportamento histórico do despacho das centrais térmicas convencionais, ainda que possa se constituir em um elemento de análise, não pode ser eleito como o período a partir do qual a decisão pelo desenvolvimento de um novo projeto de $M D L$ deva se basear.

A análise dos resultados mostrou ainda que os valores encontrados dos $\mathrm{FS}_{\text {SINy }}$ para todos os experimentos em 2008, ficou bastante abaixo daqueles encontrados para os demais anos da previsão, refletindo exatamente aquela situação em que os níveis dos reservatórios são críticos ou muito baixos no ano anterior, como ocorreu em 2007, sinalizando para que a energia ofertada por centrais térmicas convencionais flexíveis não seja substituída por uma eventual entrada no sistema elétrico de um projeto MDL.

Os resultados mostram também que as emissões associadas à energia nova comercializada nos leilões, embora possam indicar a tendência do fator de emissão do SIN não expressam quantitativamente as emissões reduzidas pelos projetos $\mathrm{MDL}$, porque não é direta a relação, mesmo considerando as centrais termelétricas mais caras, entre o despacho das térmicas convencionais e a quantidade de energia a ser deslocada, pelas atividades de um projeto MDL a ser instalado no SIN. 
Ressalte-se, finalmente, que os valores estimados para os $\mathrm{FS}_{\text {SINp }}$ para todos os experimentos são bastante significativos, indicando que os projetos elegíveis como MDL a serem conectados ao SIN são competitivos e podem ser beneficiados com importante entrada de receita adicional ao seu fluxo de caixa se conseguirem registro junto ao $\mathrm{CE}$ do $\mathrm{MDL}$. 


\section{Capítulo 7 Conclusões, Limitações e Recomendações}

\subsection{Conclusões}

A análise dos resultados encontrados mostrou que a metodologia desenvolvida no presente trabalho incorpora ganhos importantes na estimação dos créditos de carbonos a serem obtidos com a implementação das atividades de projetos de MDL conectados ao SIN. Isso ocorre porque ela internaliza ao processo de cálculo, o planejamento da expansão e os resultados dos leilões para a compra de energia nova que apontam para a elevação da participação das centrais termelétricas movidas a combustíveis fosseis no mix das fontes energéticas que serão responsáveis pela oferta de eletricidade ao sistema interligado em médio prazo.

Até pouco tempo atrás, quando a participação das centrais termelétricas era efetivamente muito reduzida e estável, as observações do passado (cinco ou até três anos) eram suficientes para projetar o mesmo padrão de comportamento em médio prazo. Ora, na hipótese de que seja mantida a atual política de expansão do parque gerador nacional, com ênfase na expansão das centrais termelétricas, então dificilmente, os fatores de emissões do SIN, calculados com base no método dos dados do despacho, poderão ser levados em conta pelo proponente de um projeto de MDL, para verificar o impacto real dos recursos oriundos da venda das CER sobre a rentabilidade do projeto.

Os procedimentos e métodos de cálculo da proposta metodológica apresentada neste trabalho, orientada por uma visão sobre o mix das fontes energéticas que provavelmente serão responsáveis pelo fornecimento de energia elétrica ao SIN baseiam-se nas informações, cenários elaborados e ferramentas computacionais semelhantes às utilizadas pelo setor elétrico para planejar a expansão da capacidade instalada do SIN. 
Verificou-se que apesar das incertezas e das limitações associadas ao uso dos modelos de simulação para calcular as emissões do $\mathrm{CO}_{2}$ relacionadas com a geração de energia elétricas dessas UTE, os resultados encontrados com a aplicação dessa proposta metodológica são coerentes com o aumento da participação das UTE emissoras dos GEE na geração de eletricidade ao SIN. Os valores obtidos dos fatores de substituição ( $F S_{S I N p}$ ) para todos os experimentos, entre 2008 e 2017 são significativamente superiores à linha de base do SIN de 2007, de 0,18tCO2;MWh, calculada com base na Tool to calculate the emission factor for an electricity system ${ }^{107}$.

Concluiu-se também que o desenvolvimento de projetos de MDL a serem conectados ao SIN poderá ser significativamente menor que o potencial existente para esse tipo de projeto, se a opção ex-ante não for uma alternativa para 0 proponente do projeto. Senão vejamos: se o projeto for adicional, então precisa comprovar que depende dos créditos de carbono para se viabilizar. Ora, se o proponente do projeto não souber de antemão o valor desse fluxo, como poderá tomar a decisão de investimento?

A solução para esse problema deve passar pela mitigação do risco (que não significa ausência de risco), ou seja, o fator de emissão assumido como linha de base do projeto, desde que calculado de forma transparente, utilizando dados, informações e modelos de simulação normalmente aceitos pelo setor elétrico no planejamento da expansão, poderia ser aceito e fixado para todo o período de obtenção de crédito escolhido.

Do mesmo modo, se o proponente escolher a linha de base do projeto baseado na análise dos dados do despacho, conforme calculado pelo método $c$ do Tool to calculate the emission factor for an electricity system a opção ex-ante deveria ser

\footnotetext{
${ }^{107}$ O fator de emissão do SIN para 2008 ainda não foi divulgado. A expectativa, no entanto, é que seja sensivelmente superior àquele observado para 2007, considerando os resultados mensais divulgados para o fator de emissão da margem operacional $\left(E_{\mathrm{OM}}\right)$. Observe-se, no entanto, que como a tendência em 2009 é de que o despacho das centrais termelétricas flexíveis seja reduzido, em função dos níveis de armazenamento de água observados em 2008, muito provavelmente, o fator de emissão do SIN em 2009 será inferior àquele calculado para 2008.
} 
também permitida. Em ambos os casos, o risco do proponente estaria vinculado a sua avaliação sobre o comportamento esperado do fator de emissão do SIN ao longo do período de obtenção de créditos do projeto candidato ao MDL.

Ou seja, se ele fizer a opção com base no fator de emissão do SIN calculado no último ano observado antes da data de entrada em operação do projeto de MDL, e se nos anos posteriores esse fator for maior e crescente, o proponente realiza prejuízos pelo "não risco". Se, por outro lado, ele opta por assumir um fator de emissão baseado nas expectativas futuras de emissões do SIN, apostando que ele será maior do que aquele observado, e essa hipótese não ocorrer, então ele perde pelo "excesso de risco".

O desenvolvimento do trabalho mostrou também que estimar corretamente o provável fluxo de recursos associados às vendas dos créditos de carbono é condição necessária, ainda que não suficiente, para que potenciais proponentes dos projetos de MDL sejam estimulados a tomarem suas decisões relativas à implementação de projeto cuja sustentabilidade dependa de alguma forma dos créditos de carbono a ele associados.

Indicaram também que, pelas características operativas e pela premissa quanto à garantia do fornecimento no SIN, nos períodos críticos ou de baixa hidraulicidade, nos quais há uma necessária elevação do despacho das UTE movidas a combustíveis fósseis, a entrada de um projeto MDL não desloca a energia elétrica gerada por essas centrais. Ao contrário, é exatamente nesses períodos que as centrais térmicas são mais utilizadas, anulando-se parcialmente, o efeito de redução de emissões pela entrada de um projeto de MDL.

Observe-se, nesse sentido, o que ocorreu em 2008, tomando-se por base o fator de emissão médio do SIN calculado com base na Tool to calculate the emission factor for an electricity system para a margem operacional. $O$ valor médio apurado de $\mathrm{FE}_{\mathrm{OMSIN2008}}$ de 0,48 reflete exatamente uma situação muito crítica dos níveis dos reservatórios, que começou a se desenhar em meados de 2007. 
No entanto, é improvável que esse patamar se mantenha em 2009, na medida em que os reservatórios encheram bastante em 2008 e a perspectiva é de que eles se mantenham cheios em 2009. Caso essa hipótese se realize haverá uma queda no fator de substituição anual, a menos que o ONS, seguindo uma recomendação de política operativa exógena ao modelo de despacho utilizado pelo setor elétrico, resolva preservar a água armazenada, e continue a despachar termelétricas convencionais.

É importante observar, no entanto, que a expectativa é de que anos de baixas e altas hidraulicidades se compensem, reduzindo o impacto dessas oscilações extremas sobre o fator de substituição medido para todo o período de obtenção de crédito $\left(\mathrm{FS}_{\mathrm{SINp}}\right)$. Por essa razão, reafirma-se o argumento, sustentado ao longo desse trabalho, de que o valor mensal e anual do fator da margem operacional do SIN reflete apenas as decisões operativas do sistema, que por natureza, são inconstantes e de curto prazo.

Essa limitação também não é superada com a aplicação da Tool to calculate the emission factor for an electricity system para a determinação do fator de emissão da margem de construção, na medida em que este fator também é calculado com base em dados do presente. Com efeito, entram para o cálculo o que for maior entre a geração das cinco últimas usinas recém-construídas ou a geração das usinas que representem $20 \%$ dos requisitos de energia. Na prática, enxerga, majoritariamente, a geração das usinas hidrelétricas, reafirmando, mais uma vez, as limitações inerentes à atual metodologia de cálculo da linha de base do SIN para projetos de MDL.

Comparando os volumes observados das emissões do SIN, divulgadas pelo MCT, de 14,4 milhões de $\mathrm{tCO}_{2}$ em 2008, os resultados encontrados pelo modelo, apresentados na Tabela 29 foram $18 \%$ superiores (17 milhões de $\mathrm{tCO}_{2}$ ). Como até fins de 2007 os níveis dos reservatórios estavam baixos, o modelo MEI preserva água e, consequentemente, despacha mais usinas termelétricas flexíveis. Em 2009, a situação se inverte: o volume de emissões é $24 \%$ inferior (11 milhões de $\mathrm{tCO}_{2}$ ) ao valor medido em 2008 de 14,4 milhões de $\mathrm{tCO}_{2}$. 
Essa diferença, embora significativa no primeiro ano, será compensada entre o $2^{\circ}$ e o 4ํa ano da projeção. Entre 2008 e 2011, a média das emissões do SIN estimadas pelo modelo $\mathrm{MEl}$ é da ordem de 14 milhões de $\mathrm{tCO}_{2} /$ ano, muito próxima, portanto, aos 14,4 milhões de $\mathrm{tCO}_{2}$ observadas em 2008. A projeção do MCT para 2017 e os resultados encontrados com a aplicação do modelo, embora ainda apresentem diferenças, aparentemente, convergem para valores mais próximos de emissões.

De acordo com as estimativas do MCT, em 2017 as novas usinas térmicas serão responsáveis por 39,3 milhões de $\mathrm{tCO}_{2}$, enquanto o modelo estimou 46 milhões de $\mathrm{tCO}_{2}$, registrando uma diferença para maior da ordem de $17 \%$. Vale destacar, no entanto, que nesse horizonte a comparação exige maior acuidade porque, enquanto a simulação feita pelo MEl estima o volume de todas as térmicas que eventualmente estejam operando em 2017, as projeções do MCT consideram apenas as emissões das novas usinas térmicas, supondo que elas começassem a operar no início de 2009.

Essas diferenças anuais já eram esperadas, tendo em vista que a preservação dos reservatórios com vistas a assegurar a garantia do fornecimento de energia elétrica é uma premissa "inegociável" do modelo. Na verdade ele sempre "prefere" operar a um custo de equilíbrio mais elevado no presente do que colocar o sistema em risco de déficit um pouco mais adiante. Entende que procedendo dessa forma, o custo para a sociedade é menor, ou seja, preservar a água armazenada é melhor do que enfrentar o risco do déficit.

No processo de elaboração da proposta metodológica, diversos aspectos relacionados com o assunto das mudanças climáticas, sobretudo no que se refere às políticas de mitigação, à economia dos custos de mitigação e adaptação e ao pós-2012 foram revisados e as discussões e informações atuais consideradas mais relevantes, em nível internacional e nacional foram incorporadas com o intuito de estabelecer as articulações existentes entre o desenvolvimento dessa proposta metodológica e o contexto mais geral ao qual o tema está inserido. 
A conclusão é que o Brasil, pelo menos em nível do setor elétrico, está caminhando no sentido contrário das tendências que estão se formando mundialmente, que apontam no sentido da implementação de ações rápidas e fortes para combater o aquecimento global. Com efeito, caso não haja mudanças significativas no novo PDEE, 2008-2017, com a expansão do sistema fortemente baseada em UTE movidas aos combustíveis fosseis, as emissões no setor elétrico triplicarão em relação aos valores registrados em 2008, conforme os dados recentemente divulgados pelo MCT, acima mencionados.

Sem desconsiderar os problemas ambientais associados à expansão da oferta de energia elétrica por meio da construção de grandes unidades hidrelétricas, sobretudo na região amazônica, e dos custos associados às tecnologias de geração de eletricidade com o uso das fontes alternativas de energia, quando comparados, em curto prazo, àqueles vinculados à geração de centrais termoelétricas movidas a combustíveis fósseis, observou-se:

- Primeiro, que nenhuma fonte incorporada à matriz energética nacional prescindiu de incentivos governamentais. Portanto, essa relativa falta de competitividade em relação à geração a partir de centrais termelétricas convencionais pode e deve ser rapidamente superada, se houver vontade política;

- Segundo, que os preços associados à geração com as fontes alternativas caíram como resultado do próprio desenvolvimento tecnológico e da ampliação dos mercados, sobretudo dos países europeus;

- Terceiro, que essa tendência deverá se aprofundar, em função do posicionamento dos países mais desenvolvidos, inclusive os EUA, de que é necessário e inadiável transitar de uma economia baseada nos combustíveis fósseis para uma economia de baixas emissões;

- Quarto, o Brasil tem recursos energéticos limpos abundantes, que o coloca numa posição privilegiada para se inserir competitivamente nesse processo de transformação da matriz energética mundial;

- Quinto, mais do que os custos mais elevados, a disseminação do uso das fontes renováveis de energia, exceto para as hidrelétricas, é obstaculizado 
pelas enormes barreiras culturais existentes. Elas impedem a realização de um grande e coordenado esforço nacional de planejamento e implementação de um amplo programa de investimentos para integrar competitivamente à indústria de energia, produção de bens e serviços associados ao segmento da geração de eletricidade a partir das fontes alternativas.

Diferente do que está ocorrendo no Brasil, chama à atenção o novo posicionamento dos EUA em relação à geração de energia limpa e incentivo a essa indústria, adoção de metas quantificadas de redução das emissões ${ }^{108}$ e incentivo às medidas de eficiência energética. Do mesmo modo, salientam-se os esforços da China, cujos investimentos para descarbonizar a sua matriz energética e adotar medidas fortes de eficiência energética são bastante significativos.

\subsection{Limitações}

Em que pesem os avanços e aprimoramentos que a adoção dessa abordagem metodológica traz para estimar e contabilizar os créditos de carbono, melhorando a base das informações colocada a disposição do proponente do projeto para a tomada de decisão de investimento devem destacadas as limitações que ainda persistem para estimar a linha de base de projetos candidatos ao MDL. São elas:

$\checkmark$ As incertezas de natureza político-institucionais, regulatórias e ambientais, que afetam diretamente o planejamento e a política operativa do setor, 0 sistema de comercialização da energia no país, as decisões e os níveis de investimentos planejados;

108 - O governo americano declarou a sua intenção de implementar um programa para reduzir as emissões dos GEE em, aproximadamente, $14 \%$ em relação ao nível observado de emissões em 2005, até 2020. Pretende ainda que até 2050 as emissões sejam reduzidas em, aproximadamente $83 \%$ em relação as emissões registradas em 2005. Os investimentos planejados são da ordem de $\$ 150$ bilhões em 10 anos, começando em 2012. Mais informações encontram-se disponíveis em: www. pewclimate.org/obama-administration. Aliás, a definição do ano base para um novo Acordo também se constitui numa questão polêmica, na medida em que os EUA elevaram bastante suas emissões entre 1990 e 2005. 
$\checkmark$ As incertezas relacionadas aos cenários projetados de crescimento da economia, com os inevitáveis rebatimentos sobre as projeções da demanda de eletricidade;

$\checkmark$ As incertezas relativas às energias naturais afluentes, sobretudo, tratandose de horizontes de planejamento mais longos. Nesse sentido, vale salientar, as mudanças que já estão sendo identificadas, em nível regional, em relação ao regime de chuvas na Bacia Amazônica e na Bacia do Paraná, em função das mudanças climáticas.

Destaca-se, ademais, que devido às restrições inerentes aos modelos de simulação, não há como generalizar os resultados dos fatores de substituição para todos os projetos candidatos ao $\mathrm{MDL}$, sendo referidos apenas àqueles claramente indicados na definição sobre a sua aplicabilidade, ou seja, projetos de empreendimentos movidos às fontes alternativas de energia a serem conectados ao SIN e/ou projetos de eficiência energética pelo lado da demanda.

Portanto, os resultados apresentados nesse trabalho refletem, exclusivamente, um valor estimado para a linha de base de projetos de MDL, a serem conectados ao SIN, para o período de crédito entre 2008 e 2017, considerando a uma configuração de base (em termos de oferta e demanda de energia), conforme descritas no Capítulo 6, do presente trabalho.

A proposta metodológica é dinâmica, esperando-se que a cada novo ciclo de planejamento os fatores de substituição sejam revistos e ajustados para refletirem as emissões evitadas com a entrada de um projeto de MDL.

\subsection{Recomendações}

Para superar essas limitações e dar conta da dinâmica que envolve o cálculo do fator de substituição, mantendo-se, porém, o núcleo essencial dessa proposta 
metodológica, apresenta-se algumas recomendações, visando o seu necessário aprimoramento. Entre os novos trabalhos que podem ser desenvolvidos, destacam-se os seguintes:

1. Desenvolver um modelo de análise qualitativa, em caráter complementar aos métodos quantitativos de estimação do fator se substituição, envolvendo a consulta sistemática a um painel de especialistas, por meio de pesquisa ou outro método de levantamento de opinião, com vistas a elaboração de cenários sobre a composição, o perfil e a participação das fontes energéticas na geração de eletricidade em médio e longo prazo. As analises e cenários projetados poderiam contribuir para reduzir as incertezas associadas aos resultados obtidos com base apenas nos métodos quantitativos;

2. Aplicar essa proposta metodológica, usando outros modelos de simulação já desenvolvidos, para determinar a geração anual das centrais termelétricas convencionais em médio prazo. A diversificação dos modelos de simulação aprimoraria as premissas e a modelagem dos dados de entrada e, consequentemente, as estimativas do fator de substituição, elevando a aceitação da proposta metodológica aqui apresentada;

3. Desenvolver um modelo de simulação simplificado e específico para estimar a geração futura das UTE flexíveis do SIN e calcular a linha de base para projetos de MDL;

4. Calcular a linha de base do $\operatorname{SIN}\left(\mathrm{tCO}_{2} / \mathrm{MWh}\right)$ atual e futura, considerando as emissões associadas às usinas hidrelétricas;

5. Estudar os impactos das mudanças climáticas sobre as energias naturais afluentes das bacias hidrográficas que servem ao SIN e incorporar esses possíveis impactos sobre a composição da geração por fonte de energia do parque gerador nacional, em médio e longo prazo. 


\section{REFERÊNCIAS BIBLIOGRÁFICAS}

ANEEL (Agência Nacional de Energia Elétrica). BIG Banco de Informação da Geração, 2008. Consulta realizada em outubro/2008.

ARROYO, V. Climate Policy Should Focus on Reducing Emissions, 2007, published on Pew Center. Disponível em: <http://www.pewclimate.org>

BROOME, J. A Ética das Mudanças Climáticas, In: Scientific American Brasil, ano $6, n^{\circ}$. 74, p. 88-93, julho 2008. Disponível em: <http://www.sciam.com.br>

CAPOOR, K., AMBROSI, P., 2007. State and Trends of the Carbon Market 2007, World Bank, Washington, D.C. Disponível em: http://siteresources.worldbank.org/NEWS/MiscContent/21319781/StateCarbon.pd $\underline{f}$

CCEE (Câmara de Comercialização de Energia). Leilões. Disponível em: $<$ http://www.ccee.org.br/cceeinterdsm/v/index.jsp?vgnextoid=d3caa5c1de88a010 VgnVCM100000aa01a8c0RCRD>

CEPEL (Centro de Pesquisa de Energia Elétrica). Manual de Referência do Modelo NEWAVE. Rio de Janeiro, 2006.

CGEE (Centro de Gestão e Estudos Estratégicos). Manual de Capacitação Mudança Climática e Projetos de Mecanismo de Desenvolvimento Limpo, 276 p., 2008. ISBN - 978-85-60755-08-0

CHARLTON, A. Mudanças Climáticas: o papel do Brasil, In: Jornal Folha de São Paulo em 27/01/2009.

CLAUSSEN, E., GREENWALD. Cap \& Trade vs. Tax, In: Pew Center on Global Change, 2007.

CQNUMC (Convenção-Quadro das nações Unidas sobre a Mudança do Clima. MCT (Edição e Tradução) Brasília, 1992 
ELLIS, J. Issues Related to a Programme of Activities under CDM. OECD/IEA, 25 p., 2006. Disponível em:

<http://www.iea.org/textbase/papers/2006/CDMissues.pdf>

EPE (Empresa de Pesquisa Energética). Estudos para a licitação da expansão da geração. Garantia física dos empreendimentos termelétricos do leilão de compra de energia nova de A-3. Revisão 1. No EPE-DEE-RE-116/2008-r3, agosto de 2008 a. Disponível em: http://www.epe.gov.br

Estudos para a licitação da expansão da geração. Garantia física dos empreendimentos termelétricos do leilão de compra de energia nova de A-5. No EPE-DEE-RE-121/2008-r0, setembro de 2008b. Disponível em: http://www.epe.gov.br

ESPARTA, A. R. J. Redução de emissões de gases de efeito estufa no setor elétrico brasileiro: a experiência do mecanismo de desenvolvimento limpo do Protocolo de Quioto e uma visão de futuro. 2008. 111 p. Tese (Doutorado). Programa Interunidades de Pós-Graduação em Energia, Universidade de São Paulo, São Paulo, 2008.

FEARNSIDE, P. M. Greenhouse gas emissions from hydroelectric dams: reply to Rosa et al., National Institute for Research in the Amazon (INPA), 2005. Disponível em: <http://philip.inpa.gov.br/publ_livres/Preprints/2006/Reply\%20to\%20Rosa\%20et\% 20al-2.pdf>

FEARNSIDE, P. M. Hydroelectric dams in the Brazilian Amazon as sources of 'greenhouse' gases. Environmental Conservation 22(1): 7-19, 1995.

Disponível em: http://philip.inpa.gov.br/publ livres/Preprints/1995/HYDRO-GHEC.pdf

FIGUERAS, C.; PHILIPS, M. Scaling Up Demand-Side Energy Efficiency Improvements. Through Programmatic CDM. Technical paper, 58 p., 2007. Disponível em: <http://www.esmap.org/filez/pubs/11212007125014_ScalingUpDemandSideEE.p $\mathrm{df}>$

FREITAS, M.A.V.; SOITO, J.L.S. Energia e recursos hídricos: vulnerabilidade, impactos e possibilidades de adaptação da geração de energia hidrelétrica no Brasil às mudanças climáticas globais, In: Parcerias Estratégicas, ㄲo. 27 , dezembro, 2008. ISSN 1413-9375. Disponível em: <http://www.cgee.org.br/parcerias/p27.php> 
GOLDEMBERG, J. (2008a). A política brasileira para o clima, In: Jornal O Estado de São Paulo, em 24/05/2008.

GOLDEMBERG, J.(ed). Introduction-Overview, p.13-20, In: Issues and Options, the Clean Development Mechanism - UNDP, New York: United Nations Publications, 1998a

HAITES, E. Carbon Markets. Prepared for United Nations Climate Change Secretariat, 2007. Disponível em:

$<$ http://unfccc.int/files/cooperation_and_support/financial_mechanism/application/ pdf/haites.pdf>

HAMWEY, R.; SZEKELY, F. Pratical Aproaches in the Energy Sector, chapter 10, pp.119-136, In: Issues and Options, the Clean Development Mechanism UNDP, New York: United Nations Publications, 1998. Disponível em: <http://www.energyandenvironment.undp.org/undp/index.cfm?module=Library\&pa ge=Document\&Document $\mid \mathrm{D}=5041>$

HINOSTROZA, M.; CHENG, C., et. al. Potencials and barriers for end-use energy efficiency under programmatic CDM. CD4CDM, Working paper $n^{\circ} 3,62$ p., 2007.

Disponível em: <http://www.cd4cdm.org/Publications/pCDM\&EE.pdf>

International Energy Agency (IEA), 2008. World Energy Outlook (WEO)

Strategic Challenges

2007. World Energy Outlook (WEO), Key

IPCC (Intergovernmental Panel Climate Change). Contribution of Working Group I to the Fourth Assessment Report of the Intergovernmental Panel on Climate Change, Summary for Policymakers, 2007a.

Mudança do Clima 2007: Mitigação da Mudança do Clima, Sumário para os formuladores de políticas (SFP), Contribuição do Grupo de Trabalho III ao Quarto Relatório de Avaliação, 2007b.

Impactos, Adaptação e Vulnerabilidade, Sumário para os formuladores de 
políticas (SFP), Contribuição do Grupo de Trabalho II ao Quarto Relatório de Avaliação, abril, 2007c.

National Greenhouse Gas Inventories, vol.2, 1996.

\section{Revised Guidelines for}

OLIVEIRA, A.S. e RIBEIRO, L.S. Relatório da COP 7. MMA - Núcleo de Trabalho em Mudanças Climáticas, 2002.

MCT (Ministério da Ciência e Tecnologia)/BNDES(Banco Nacional de Desenvolvimento Econômico e Social). Efeito Estufa e a Convenção sobre Mudança do Clima, 1999. Disponível em:<http://mct.gov.br/upd blob/0000/346.pdf $>$

MCT (Ministério da Ciência e Tecnologia )/CIMGC(Comissão Interministerial para Mudança Global do Clima). Nota de Esclarecimento, 2008. Disponível em: $<$ www.mct.gov.br>

MCT (Ministério da Ciência e Tecnologia)/CIMGC(Comissão Interministerial para Mudança Global do Clima). Cálculo dos Fatores de Emissão de $\mathrm{CO}_{2}$ pela geração de energia elétrica no Sistema Interligado Nacional do Brasil, 2007.

MCT (Ministério da Ciência e Tecnologia). Status dos Projetos de MDL no Brasil, atualizado em fevereiro de 2009.

MICHAELOWA, A. - Sector Level Greenhouse Gas Emissions: Estimation, Projections and Trading. Paper for the Workshop. Russian energy prospects and the implication for emission and climate policy, 1999. Disponível em:<http://www.emissions.de/climateru/documents/sectoral-emissions/>

MMA (Ministério do Meio Ambiente). Plano Nacional de Mudança Climática, Sumário Executivo, 2008. Disponível em: $<$ http://www.mma.gov.br/sitio/index.php?ido=conteudo $\cdot$ monta\&idEstrutura=96\&id Conteudo $=7929>$

MME (Ministério das Minas e Energia), 2007. Plano Decenal de Expansão de Energia Elétrica - PDEE 2007-2016.

MME/EPE - Nota Técnica DEN 02/08 - Projeção da Demanda de Energia para o Plano Decenal de Expansão de Energia, 2008-2017, 2008. 
MOUTINHO, P.; MARTINS, S. O. - Plano Nacional sobre Mudança do Clima: oportunidades e desafios, In: Revista FBMC, Ano I - dezembro 2008, p. 22-24. Fórum Brasileiro de Mudanças Climáticas.

NOBRE, C. A. - Mudanças Climáticas e o Brasil, In: Parcerias Estratégicas, número 27, dezembro, 2008. ISSN 1413-9375

Disponível em: <http://www.cgee.org.br/parcerias/p27.php>

OLIVEIRA, A. Mercado Elétrico: Centralizar a gestão de riscos? In: Regulação e Concorrência no Brasil: Governança, Incentivos e Eficiência. Capítulo 10, IPEA, Rio de Janeiro, 2007.

Disponível em: <http://www.ipea.gov.br/default.jsp>

OLIVEIRA at al. Documentação do Modelo de Equilíbrio Integrado, 2008- em elaboração

ONS (Operador Nacional do Sistema). Histórico da Operação - Geração de Energia, 2008 a. Disponível em:

<http://www.ons.org.br/historico/geracao_energia.aspx>

Planejamento da Operação

Energética - Curva de Aversão ao Risco 2007/2008, 2008 b

Plano Anual da Operação Energética -

PEN 2008. Relatório Executivo, 2008 c. Disponível em:

$<$ http://www.ons.org.br/avaliacao condicao/planejamento energetica.aspx>

Armazenada, 2008 d. Disponível em:

Histórico da Operação - Energia

$<$ http://www.ons.org.br/historico/energia armazenada out.aspx>

Metodologia de incorporação da curva de aversão a risco ao modelo NEWAVE método CAR, NT 007/2004. 
PANAYOTOU, T. Six Questions and Governance, chapter 4, pp. 45- 52, on Issues and Options, the Clean Development Mechanism - UNDP, New York: United Nations Publications, $1998 . \quad$ Disponível em: $<$ http://www.energyandenvironment.undp.org/undp/index.cfm?module=Library\&pa ge=Document\&Document $\mid \mathrm{D}=5041>$

PNUD (Programa das Nações Unidas para o Desenvolvimento). Relatório de Desenvolvimento Humano, 2007/2008, 402 p. ISBN 978-972-40-3313-6.

SAMPA, G.; NOBRE C. Mudanças Climáticas e Amazônia, In: Revista FBMC, Ano I - dezembro 2008, p. 44- 46. Fórum Brasileiro de Mudanças Climáticas.

SANTOS, M. A.; PINGUELLI L. R., et al. Emissões de gases de efeito estufa por reservatórios de hidrelétricas - Oecol. Bras., 12 (1): 116-129, 2008. Disponível em: <http://www.ppgecologia.biologia.ufrj.br/oecologia/index.php/oecologiabrasiliensis /article/view/219/185 ->

SHIMADA, K. The Legacy of the Kyoto Protocol: Its Role as the Rulebook for an International Climate Framework - International Review for Environmental Strategies, vol. 5 no 1, p. 3-14, 2004.ISSN 1345-7594

Disponível em: <http://www.iges.or.jp/en/pub/ires/volume5_1.html>

SOLIANO, O., REIS, T. M., et al. Renewable Energy as a tool to assure continuity of low emissions in the Brazilian Electric Power Sector, IEEE, 2006.

Stern Review: The Economics of Climate Change, 2008a. Sumário Executivo 2008 b. Sumário de Conclusões

UNFCCC/CDM. Tool to calculate the emission factor for an electricity system, version 01. EB 35 Report, Annex 12, 2007.

-Tool for the demonstration and assessment for additionality, version 05, EB 39 Report, Annex 10, 2008.

Consolidated baseline methodology for grid-connected electricity generation from renewable sources, ACM 0002, version 07, EB 36, Annex 11, 2007. 
COP 7 Decisão 17/CP.7, Anexo: Modalidades

e procedimentos para um mecanismo de desenvolvimento limpo, 2001

-CDM Statistics, 2009. (Disponível em:

$<$ http://cdm.unfccc.int/Statistics/index.html>

Kyoto Protocol, $1997 . \quad$ (Disponível em:

<http://unfccc.int/kyoto_protocol/items/2830.php>

Registered Project Activities by Host Party. Disponível em: http://cdm.unfccc.int/Statistics/Issuance/CERslssuedByHostPartyPieChart.html. Consulta realizada em 25/03/2009

Clean Development Mechanism (CDM). Disponível em: http://cdm.unfccc.int/index.html

YADOMI, K. ; MIZUNO, Y. - IGES CDM Project Data Analysis, 2006. Disponível em

http://www.iges.org.jp/en/cdm/report.html

YAMIN, F. Operational and Institutional Challenges, chapter 6, pp. 53-

79. In: Issues and Options, the Clean Development Mechanism - UNDP, New York: United Nations Publications, 1998.Disponível em: http://www.energyandenvironment.undp.org/undp/index.cfm?module=Library\&pag $\mathrm{e}=$ Document\&Document $\mid \mathrm{D}=5041$

WATSON, R. Financing the Transition to a Low Carbon Economy Beyond Stern: Financing International Investment in Low Carbon, Washington, DC, 2007. Disponível em: <http://www.tyndall.ac.uk/ppts/robert_watson.ppt>

WEITZMAN, M. L.The Stern Review of the Economics of Climate Change. Book review for Journal of Economic Literature (JEL), Harvard University, Cambridge, Massachusetts, 2007 


\section{REFERÊNCIAS CONSULTADAS}

ABRANCHES, S. Cuidar do clima global é cuidar do Brasil, In: Scientific American Brasil, Edição Especial: Brasilian Forum Climate Change, $n^{\circ}$. 19, p. 5963, s/data. Disponível em: <http://www.sciam.com.br>

BODANSKY, D. International Efforts Beyond 2012: a Survey of Approaches, prepared for the Pew Center on Global Climate Change, 2004.

Disponível em: <http://www.pewclimate.org/docUploads/2012\%20new.pdf>

BUCHNER, B. Policy Uncertainty, Investment and Commitment Periods. OECD/IEA, p.28, 2007. Disponível em: <http://regserver.unfccc.int/seors/attachments/file_storage/ghxyhz9|4lc6qib.pdf>

CHÂTEAU, B. A vida depois do petróleo, In: Scientific American Brasil, Edição Especial: Brasilian Forum Climate Change, $n^{\circ}$. 19, p. 46-51, s/data. Disponível em: <http://www.sciam.com.br>

CUTAJAR, M. Z. Reflections on the Kyoto Protocol - Looking back to See Ahead, on International Review for Environmental Strategies (IGES), vol. 5 no 1, p. 61- 70, 2004. ISSN 1345-7594.

Disponível em: <http://www.iges.or.jp/en/pub/ires/volume5_1.html>

D'ARAUJO, R. P. "Freud e a jabuticaba". Agência CanalEnergia, janeiro/2009

EGENHOFER, C. et al. Low-Carbon Technologies in The Post- Bali Period: Accelerating their Development and Deployment. ECP (European Climate Platform), Report no 4, December, 2007

ELLIS, J.; BARON, R.; BUCHNER, B. - SD- What, Where, When and How? OECD/IEA, $\quad 35$ p., $2007 . \quad$ Disponível em: <http://www.oecd.org/dataoecd/15/12/39725449.pdf>

ELLIS, J. and SAMI K.. Overcoming Barriers to Clean Development Mechanism Projects, IEA and UNEP, Paris, 2007. 
Ellis, Jane and Dennis Tirpak. Linking GHG Emission Trading Systems and Markets, IEA and UNEP, Paris, 2006.

EKELAND, I. Economia e efeito estufa, In: Scientific American Brasil, Edição Especial: Brasilian Forum Climate Change, $\mathrm{n}^{\circ}$. 19, p. 64-71, s/data. Disponível em: <http://www.sciam.com.br>

EPE (Empresa de Pesquisa Energética) - A questão socioambiental no planejamento de expansão da oferta de energia elétrica, p. 238 , Rio de Janeiro, 2006. ISBN: 978-85-60025-01-5.

GOLDEMBERG, J. Energia, Meio Ambiente e Desenvolvimento, São Paulo: EDUSP, CESP, 1998b

GRUBB, M. Kyoto and the Future of International Climate Change Responses: From Here to Where? In: International Review for Environmental Strategies (IGES), vol. 5 no 1, p. 15-38, 2004. ISSN 1345-7594.

Disponível em: <http://www.iges.or.jp/en/pub/ires/volume5_1.html>

HAITES, E.; YAMIN, F. Overview of the Kyoto Mechanisms. In: International Review for Environmental Strategies (IGES), vol. 5 no 1, p. 199-215, 2004. ISSN 1345-7594. Disponível em: <http://www.iges.or.jp/en/pub/ires/volume5_1.html>

HAITES, E. Estimating the Market Potential for the Clean Development Mechanism: Review of Models and Lessons Learned, World Bank Carbon Finance Business PCFplus Research program, International Energy Agency and International Emissions Trading Association, 2006, Washington, D.C.

HOURCADE, J. C.; AMBROSI, P.; HALLEGATTE, S. Antes que seja tarde demais, In: Scientific American Brasil, Edição Especial: Brasilian Forum Climate Change, $n^{\circ} 19$, p. 20-24, s/data. Disponível em: <http://www.sciam.com.br>

ICTSD (International Center for Trade and Sustainable Development). Linking Trade, Climate Change and Energy, 2006. Disponível em: $<$ http://www.ictsd.org>

JOCHEM, E. K. Combatendo o desperdício, In: Scientific American Brasil, Edição Especial: Brasilian Forum Climate Change, $\mathrm{n}^{\circ}$ 19, p.72-75, s/data. Disponível em: <http://www.sciam.com.br> 
KRUG, T. Impacto, vulnerabilidade e adaptação das florestas à mudança do clima, In: Parcerias Estratégicas, número 27, dezembro, 2008. ISSN 1413-9375. Disponível em: <http://www.cgee.org.br/parcerias/p27.php>

MATSUO, N. The Clean Development Mechanism: Issue and Opportunities, on International Review for Environmental Strategies (IGES), vol. 5 no 1, p. 233-240, 2004. ISSN 1345-7594.

Disponível em: <http://www.iges.or.jp/en/pub/ires/volume5_1.html>

MONBIOT, G. Heat. Penguin Books, London, 2006

NORDHAUS, W. D. Life after Kyoto: Alternative Approaches to Global Warming Policies. National Bureau of Economic Research, Working Paper 11889. Cambridge, Massachusetts, 2005.2 Disponível em: <http://www.econ.yale.edu/ nordhaus/kyoto_long_2005.pdf>

ÖLS, S.; SIMS, R.; KIRCHNER, N. Contribution of renewable to energy security, IEA Information Paper, Paris, 2007. Disponível em: <http://www.iea.org/textbase/papers/2007/so_contribution.pdf>

PACHI, F. O que você está disposto a mudar, In: Scientific American Brasil, Edição Especial: Brasilian Forum Climate Change, $n^{\circ}$. 19, p. 41-45, s/data. Disponível em: <http://www.sciam.com.br>

Pew Center on Global Climate Change . A Look at Emission Targets, 2007. Disponível em: http://www.pewclimate.org/what s being done/targets

Pinto, L. Estudo do Impacto da Implantação de Usinas Eólicas na Oferta de Energia do Sistema Interligado Nacional- Análise Qualitativa. Engenho Pesquisa, Desenvolvimento e Consultoria Ltda, 2007

Pinto, L. Estudo do Impacto da Implantação de Usinas Eólicas na Oferta de Energia do Sistema Interligado Nacional- Análise Quantitativa. Engenho Pesquisa, Desenvolvimento e Consultoria Ltda, 2007

PUGNALONI, I.A. A. Uma Itaipu de poluição, energia cara e aquecimento global, janeiro, 2009.2 Disponível em: <http://www.enercons.com.br/_imagens/noticias/uma-itaipu-de-poluicao.pdf> 
SAMPAIO G.; NOBRE, C. A.; SALAZAR, L. Cenários de mudança climática para a América do Sul para o final do século 21, In: Parcerias Estratégicas, número 27, dezembro, 2008. ISSN 1413-9375. Disponível em: http://www.cgee.org.br/parcerias/p27.php

STERN, N.; TAYLOR, C. Climate Change: Risk, Ethics and the Stern Review, Science 317 (5835): 203-204, 2007 


\section{APÊNDICE A - Descrição da Ferramenta Aprovada pelo CE do MDL para Calcular o Fator de Emissão de Sistema Elétrico ${ }^{109}$}

Este apêndice apresenta a ferramenta aprovada pelo Comitê Executivo (CE) do Mecanismo de Desenvolvimento Limpo (MDL) para calcular o fator de emissão de sistemas elétricos de projetos candidatos ao MDL a serem conectados à rede interligada. Na seqüência são analisados os resultados da aplicação pela Comissão Interministerial de Mudança Global do Clima (CIMGC) ${ }^{110}$ dessa ferramenta para calcular o fator de emissão do Sistema Nacional Interligado SIN. Em função de mudanças na configuração adotada pela CIMGC, o SIN foi considerado como sistema único e os fatores de emissões anteriormente calculados por subsistema foram revistos, sendo os mesmos recalculados desde janeiro de 2006 pela nova configuração. O Capítulo se encerra com uma análise crítica sobre o uso dos fatores de emissão calculados com bases nessa ferramenta para os projetos candidatos ao MDL a serem conectados no SIN.

\section{A.1 Escopo, aplicabilidade}

Essa ferramenta determina o fator de emissão ou a linha de base de atividades de projetos que substituem eletricidade gerada na rede elétrica, seja porque o projeto $M D L$ oferta mais eletricidade à rede, seja porque a proposição do projeto resulta em redução da eletricidade que de outra forma seria gerada pelas usinas conectadas à rede elétrica.

\footnotetext{
109 - Em inglês, Tool to calculate the emission factor for na eletricity system, versão 01, aprovado na 35 reunião do CE do MDL, em outubro de 2007.

110 - Essa ferramenta foi aplicada pela Comissão Interministerial para Mudança Gçlobal do Clima (CIMGC) para determinar o fator de emissão do SIN. A CIMGC é a Autoridade Nacional Designada (AND) brasileira, criada pelo Decreto de 7 de julho de 1999, alterado pelo Decreto de 10 de janeiro de 2006, com a finalidade de articular as ações de governo decorrentes da Convenção-Quadro das Nações Unidas sobre Mudança do Clima e seus instrumentos subsidiários de que o Brasil seja parte.
} 
O fator de emissão do sistema elétrico, que mede o deslocamento da energia gerada pelas usinas que servem ao sistema elétrico pela entrada do projeto MDL, é calculado com base nos conceitos da margem operacional (OM), da margem de construção (BM) e da margem combinada (CM).

A margem operacional é definida pelo conjunto de usinas existentes, cujas gerações podem ser afetadas com as atividades do projeto de MDL, ou seja, "a margem de operação visa avaliar a contribuição das usinas que seriam despachadas na ausência da geração do projeto" (MCT, 2007, p.2). A margem de construção se refere aos empreendimentos, cujas construções poderão ser afetadas com a implementação das atividades do projeto MDL, ou seja, "a margem de construção visa avaliar a contribuição das usinas que seriam construídas caso o projeto não existisse" (Ibid.).

A margem combinada reflete o fator de emissão do sistema elétrico, sendo calculada pela média ponderada das duas primeiras. Os fatores de ponderação padrão sugeridos na metodologia são 0,5 para a OM e 0,5 para a BM. Porém os proponentes também podem propor alternativas dos pesos para consideração do CE do MDL, em função das tecnologias de geração do projeto de MDL e do período de obtenção de créditos. Por exemplo, projetos de energia eólica e solar podem adotar os pesos 0,75 para a OM e 0,25 para a BM.

Além disso, "os acréscimos de capacidade e os valores gerados das usinas elétricas registradas como projetos de MDL devem ser excluídos de todos os cálculos" (Ibid, p.2).

\section{A.2 Métodos de cálculo}

De acordo com a metodologia aprovada pelo CE do MDL quatro métodos podem ser usados para calcular a margem operacional: 

a. Margem operacional simples;
b. Margem operacional simples ajustada;
c. Análise dos dados do despacho;
d. Margem operacional ponderada.

O método $c$, da análise dos dados do despacho por ser considerado o mais adequado pelo $\mathrm{CE}$ do $\mathrm{MDL}$, foi escolhido pelo MCT, que dispunha de todas as informações necessárias para aplicá-lo.

O fator de emissão da margem operacional é definido "como a média ponderada dos fatores de emissão das usinas que compõem os $10 \%$ superiores da curva de prioridade de despacho e é calculado para cada hora" (MCT, 2007, p.2). O fator de emissão de cada usina existente no sistema é calculado com base nos valores de geração e consumo de combustíveis da usina do ano anterior. Para as novas usinas térmicas que entrem em operação a cada ano, deverá ser adotado como seu fator de emissão, para o correspondente ano, o valor referente ao do ano anterior de uma usina similar (MCT, 2007).

A metodologia fornece os procedimentos para a determinação dos seguintes parâmetros: fator de emissão da margem combinada no ano y $\left(\mathrm{FE}_{\text {grid, } \mathrm{CM}, \mathrm{y}}\right)$, fator de emissão da margem operacional do ano y $\left(\mathrm{FE}_{\text {grid,OM,y }}\right)$ e fator de emissão da margem de construção do ano y ( $\left.\mathrm{FE}_{\text {grid,BM,y }}\right)$.

A aplicação da ferramenta requer:

$\checkmark$ Identificação do sistema elétrico do projeto e do sistema elétrico interligado ao qual o projeto será conectado;

$\checkmark$ Determinação das importações (energia fornecida pelo sistema elétrico interligado ao sistema elétrico do projeto) e exportações (eletricidade transferida do sistema do projeto para o sistema elétrico interligado), se necessário;

$\checkmark$ Seleção do método para calcular os fatores de emissões da margem operacional $\left(\mathrm{EF}_{\text {gridCM,y }}\right)$ e da margem de construção $(\mathrm{FE}$ gridBM,y); 
$\checkmark$ Cálculo do fator de emissão da margem de construção (FE gridBM,y) e do fator de emissão da margem combinada ( $\mathrm{FE}$ gridCM,y).

A.3 Identificação das fronteiras do projeto

A metodologia recomenda que se a Autoridade Nacional Designada - AND delimita o sistema elétrico interligado, então essa delimitação deve ser usada. Se essa delimitação não estiver disponível, o proponente do projeto deve definir o sistema elétrico do projeto e o sistema elétrico conectado e justificar suas suposições no Project Design Document (PDD).

Sugere também os seguintes critérios para determinar a existência de significativas restrições de transmissão:

- Em caso de sistema elétrico com mercado spot: existem diferenças do preço da eletricidade, sem considerar os custos de transmissão e distribuição, de mais de $5 \%$ entre os sistemas em $60 \%$ ou mais das horas do ano;

- A linha de transmissão é operada com $90 \%$ ou mais da sua capacidade durante $90 \%$ ou mais das horas do ano.

Para determinar o fator da margem de construção, a extensão espacial é limitada ao sistema elétrico ao qual o projeto MDL será conectado, a menos que recente ou provável adição de capacidade de transmissão viabilize significativa elevação das importações. Neste caso, a capacidade de transmissão pode ser considerada como um recurso da margem de construção.

Importações e exportações de eletricidade são calculadas com base nos mesmos métodos de cálculo estabelecidos para determinar o fator de emissão da margem operacional, acima mencionados. 


\section{A.4 Parâmetros e Validação}

Fator de Emissão da Margem Operacional

Para calcular o fator de emissão da margem operacional o proponente do projeto pode escolher entre qualquer um dos quatro métodos de cálculo anteriormente mencionados. No entanto, o método $a$, da média simples só poderá ser usado se os recursos de baixo custo/despacho de base constituem menos que $50 \%$ do total da geração da rede. Nesse caso, as gerações das usinas de baixo custo e despachadas na base não são incluídas nas equações que determinam o fator de emissão.

Os demais métodos são usados de acordo com a disponibilidade dos dados exigidos para que possam ser utilizados. O método $\boldsymbol{c}$, quando aplicável, é preferível aos demais, seguido dos métodos $\boldsymbol{b}$ e $\boldsymbol{d}$. O método $\boldsymbol{d}$ é muito semelhante ao método $\boldsymbol{a}$, porém se diferencia deste porque em todas as equações as gerações das usinas de baixo custo e as usinas despachadas na base são incluídas.

Todas as equações e dados necessários para calcular o fator de emissão da margem operacional e da margem de construção por qualquer dos quatro métodos encontram-se no Anexo 12, da $35^{\text {a }}$ reunião do $\mathrm{CE}$ do $\mathrm{MDL}$, realizada em outubro de 2007.

Cálculo do Fator de Emissão da Margem de Construção

Para calcular o fator de emissão da margem de construção o primeiro passo é identificar o conjunto de usinas que formarão essa margem, com base nos seguintes critérios: 
$\checkmark$ O conjunto das 5 usinas mais recentemente construídas;

$\checkmark$ O conjunto de capacidade adicional ao sistema elétrico que compreende os $20 \%$ da geração do sistema e que foi recentemente construída.

O proponente do projeto deve escolher o conjunto de usinas que representam a maior geração anual. Os empreendimentos registrados no MDL não devem ser incluídos no grupo de usinas que formarão a margem de construção, a menos sejam despachadas compulsoriamente pelo operador do sistema elétrico. Devem ser excluídos do conjunto de usinas, os empreendimentos construídos há mais de 10 anos.

Para calcular os fatores de emissões associados às usinas do grupo que compõe a margem de construção um dos dois critérios acima mencionados deve ser escolhido, de acordo com a disponibilidade dos dados existentes sobre o grupo de usinas selecionadas.

Fator de Emissão da Margem Combinada

Calculados os fatores de emissão da margem operacional e da margem de construção, o fator de emissão da margem combinada é simplesmente calculado pela média ponderada dos dois primeiros. $\mathrm{O}$ fator de ponderação para todos os projetos é de 0,50 para o primeiro período de obtenção de créditos, e de 0,25 para a margem operacional e 0,75 para a margem de construção para o $2^{\circ}$ e $3^{\circ}$ períodos de obtenção de créditos. Excetuam-se os projetos de geração solar e eólica, cujos pesos são de 0,75 para a margem operacional e de 0,25 para a margem de construção para os três períodos de créditos. 
Validação dos dados

Se o proponente do projeto adotar o método $\mathrm{a}$, b ou $\mathrm{d}$, então a validade dos dados poderá ser feita ex-ante, no momento de registro do projeto junto ao CE do MDL e valerá para o período 10 anos (ou 7 anos, se o período de obtenção de créditos for de 21 anos), ou ex-post, situação que a validação dos dados se dará no ano em que as atividades do projeto deslocam eletricidade da rede elétrica. Requer, no entanto, que os cálculos dos fatores de emissão da margem operacional e da margem de construção sejam atualizados anualmente.

Se o proponente do projeto optar pelo método $\boldsymbol{c}$, da análise dos dados do despacho, a validação será obrigatoriamente ex-post, nos termos acima descritos. A data de validação deve ser documentada no PDD (Project Design Document) e não poderá ser mudada durante o período de crédito.

A.5 - Critérios e equações para aplicação do método da análise dos dados do despacho

Conforme mencionado o método $\boldsymbol{c}$, da análise dos dados do despacho é considerado pelo Comitê Executivo (CE) do MDL como o que melhor reflete o deslocamento da eletricidade da rede elétrica como resultado da entrada das atividades de um projeto MDL. A característica desse método que o diferencia dos demais é determinar o fator de emissão da margem operacional do sistema elétrico com base nas emissões associadas às usinas que são despachadas no topo do sistema elétrico onde o projeto desloca eletricidade, durante cada hora.

Seguindo os procedimentos do método $\boldsymbol{c}$, para determinar o conjunto das usinas que formam o topo do despacho é necessário obter do operador do sistema elétrico interligado a ordem do despacho de cada usina do sistema, a partir dos custos de geração de cada usina, incluindo usinas das quais a eletricidade é 
importada e a energia (MWh) que é despachada por todas as usinas do sistema, durante cada hora que as atividades do projeto deslocam eletricidade da rede.

A cada hora, empilham-se as usinas geradoras, usando a ordem de mérito. $\mathrm{O}$ grupo de usinas despachadas na margem inclui as unidades no topo que representam um percentual do total da eletricidade despachada na hora $h$, que deve ser o maior entre:

- $10 \%$;

- A quantidade de eletricidade deslocada pelas atividades do projeto durante a hora $h$ dividida pela geração total da rede durante na hora $h$.

O fator de emissão da margem operacional é calculado pela seguinte equação:

$\mathrm{EF}_{\text {grid,OM-DD,y }}=\frac{\sum_{\mathrm{h}} \mathrm{EG}_{\mathrm{PJ}, \mathrm{h}} \times \mathrm{EF}_{\mathrm{EL}, \mathrm{DD}, \mathrm{h}}}{\mathrm{EGPJ,y}}$, onde:

$\mathrm{EF}_{\text {grid,OM-DD,y }}=$ Fator de emissão da margem operacional dos dados do despacho no ano $y\left(\mathrm{tCO}_{2} / \mathrm{MWh}\right)$

$E G_{\mathrm{PJ}, \mathrm{h}}=$ Eletricidade horária deslocada pela atividade do projeto na hora $h$ do ano $y$ (MWh)

$\mathrm{EF}_{\mathrm{EL}, \mathrm{DD}, \mathrm{h}}=$ Fator de emissão das unidades geradoras do topo despachadas por ordem de mérito na hora $h\left(\mathrm{tCO}_{2} / \mathrm{MWh}\right)$

$E G_{\mathrm{PJ}, \mathrm{y}}=$ Total da eletricidade deslocada pela atividade do projeto no ano $y(\mathrm{MWh})$

$\mathrm{h}=$ horas do ano $y$ que a atividade do projeto desloca eletricidade da rede $y=$ ano que a atividade do projeto desloca eletricidade da rede

Se horariamente o consumo do combustível está disponível então o fator de emissão é determinado como segue: 
$E F_{E L, D D, h}=\frac{\sum_{i, n} F C_{i, n, h} \times N C V_{i, y} \times E F_{C O_{2}, i, y}}{\sum_{n} E G_{n, h}}$, onde:

$\mathrm{EF}_{\mathrm{EL}, \mathrm{DD}, \mathrm{h}}=$ Fator de emissão das unidades geradoras do topo despachadas por ordem de mérito na hora $h$

$\mathrm{FC}_{\mathrm{i}, \mathrm{n}, \mathrm{h}}=$ Montante de combustível do tipo $i$ consumido pela usina $n$ na hora $h$ (unidade de massa ou volume)

$\mathrm{NCV}_{\mathrm{i}, \mathrm{y}}=$ Poder calorífico líquido(conteúdo energético) do combustível fóssil do tipo $i$ no ano $y$ (GJ/unidade de massa/volume)

$\mathrm{EF}_{\mathrm{CO} 2, \mathrm{i}, \mathrm{y}}=$ Fator de emissão do combustível fóssil do tipo $i$ no ano $y\left(\mathrm{tCO}_{2} / \mathrm{GJ}\right)$

$E G_{n, h}=$ Eletricidade gerada e distribuída na rede por $n$ unidades geradoras na hora $h$

$\mathrm{n}=$ unidades geradoras que compõem o topo do despacho

$\mathrm{i}=$ tipo de combustível fóssil queimado pelas $n$ unidades geradoras no ano $y$

$\mathrm{h}=$ número de horas do ano $y$ que a atividade do projeto desloca eletricidade da rede

$y=$ ano em que a atividade do projeto desloca eletricidade da rede

Se o fator de emissão for calculado com base apenas na eletricidade gerada e distribuída à rede pelas usinas $u$ no ano $y$, nas suas respectivas eficiências e no tipo de combustível usado por elas, então o fator de emissão é calculado como segue:

$E F_{E L, D D, h}=\sum_{n} \frac{E G_{n, h} \times E F_{E L, n, y}}{\sum_{n} E G_{n, h}}$, onde:

$\mathrm{EF}_{\mathrm{EL}, \mathrm{DD}, \mathrm{h}}=$ Fator de emissão das unidades geradoras do topo despachadas por ordem de mérito na hora $h\left(\mathrm{tCO}_{2} / \mathrm{MWh}\right)$

$E G_{n, h}=$ Eletricidade gerada e distribuída na rede por $n$ unidades geradoras na hora $h(\mathrm{MWh})$ 
$\mathrm{EF}_{\mathrm{EL}, \mathrm{n}, \mathrm{y}}=$ Fator de emissão da usina geradora $n$ no ano $y$

$\mathrm{n}=$ unidades geradoras do topo do despacho

$\mathrm{h}=$ horas no ano y que a atividade do projeto desloca eletricidade da rede

O fator de emissão das usinas geradoras $n$ deve ser determinado de acordo com o método da margem operacional simples, usando as opções B1, B2 e B3 cuja escolha depende da disponibilidade dos dados necessários para efetuar os cálculos ${ }^{111}$.

O fator de emissão da margem de construção, conforme anteriormente mencionado é calculado com base no conjunto $m$ de usinas recentemente construídas. Ele é determinado considerando a quantidade de eletricidade gerada pelo conjunto dessas usinas e seus respectivos fatores de emissões. $O$ fator de emissão da margem de construção é calculado como segue:

$\mathrm{EF}_{\text {grid,BM }, \mathrm{y}}=\frac{\sum_{m} \mathrm{EG}_{\mathrm{m}, \mathrm{y}} \times \mathrm{EF}_{\mathrm{EL}, \mathrm{m}, \mathrm{y}}}{\sum_{m} \mathrm{EG}_{\mathrm{m}, \mathrm{y}}}$, onde:

$\mathrm{EF}$ grid,BM,y $=$ Fator de emissão da margem de construção no ano $y\left(\mathrm{tCO}_{2} / \mathrm{MWh}\right)$;

$E G_{m, y}=$ Quantidade líquida de eletricidade gerada e distribuída na rede por $\mathrm{m}$ unidades geradoras no ano $y(\mathrm{MWh})$;

$\mathrm{EF}_{\mathrm{EL}, \mathrm{m}, \mathrm{y}}=$ Fator de emissão da unidade geradora $m$ no ano $y\left(\mathrm{tCO}_{2} / \mathrm{MWh}\right)$;

$\mathrm{m}=$ unidades geradoras incluídas na margem de construção;

$\mathrm{y}=$ mais recente ano para o qual o dado de geração da unidade está disponível.

O fator de emissão da margem combinada é simplesmente a média ponderada desses dois fatores e é calculado como segue:

111 - Para mais detalhes o método a da margem operacional simples ver Anexo 12, do Relatório da 35르 reunião de CE do MDL realizada em 19 de outubro de 2007. 
$\mathrm{EF}_{\text {grid, } \mathrm{CM}, \mathrm{y}}=\mathrm{EF}_{\text {grid,OM-DD,y }} \times \mathrm{W}_{\mathrm{OM}}+\mathrm{EF}_{\text {grid,BM,y }} \times \mathrm{W}_{\mathrm{BM}}$, onde:

$\mathrm{EF}$ grid, $\mathrm{CM}, \mathrm{y}=$ Fator de emissão da margem combinada

$\mathrm{EF}$ grid,BM,y $=$ Fator de emissão da margem de construção no ano $y\left(\mathrm{tCO}_{2} / \mathrm{MWh}\right)$

$\mathrm{EF}_{\text {grid,OM,y }}=$ Fator de emissão da margem operacional no ano $y\left(\mathrm{tCO}_{2} / \mathrm{MWh}\right)$

$\mathrm{W}_{\mathrm{OM}}=$ Fator de ponderação da margem operacional (\%)

$\mathrm{W}_{\mathrm{BM}}=$ Fator de ponderação da margem de construção (\%)

Os dados do despacho devem se referir ao ano em que a atividade do projeto desloca eletricidade da rede e o fator de emissão da margem operacional deve ser anualmente atualizado, durante o período de obtenção de créditos.

\section{A.6 Cálculo dos Fatores de Emissão do SIN}

Seguindo esse procedimento, os fatores de emissão foram calculados pelo Ministério da Ciência e Tecnologia (MCT) e o Ministério de Minas e Energia (MME), com a participação do Operador Nacional do Sistema (ONS), considerando:

- O fator de emissão da margem operacional definido como a média ponderada dos fatores de emissão das usinas que compõem os $10 \%$ superiores da curva de prioridade de despacho, calculado para cada hora;

- O fator de emissão de cada usina existente no sistema, calculado anualmente, a partir dos valores de geração e consumo de combustíveis da usina do ano anterior;

- O fator de emissão para as novas usinas térmicas igual ao adotado para uma usina similar no ano anterior. 
Um ponto fundamental na aplicação da ferramenta para definir o fator de emissão foi a consideração do SIN como sistema único, dado que as análises indicaram que não há restrições significativas de transmissão que justifiquem, atualmente e no futuro, o cálculo dos fatores de emissões por subsistemas.

\section{A.6.1 Determinação do Fator de Emissão da Margem Operacional}

O fator de emissão da margem de operação $(\mathrm{OM})$ do SIN foi calculado de acordo com a Equação (A.1), a partir dos valores de geração horária de cada usina e dos fatores de emissão de $\mathrm{CO}_{2}$ por usina termelétrica. Para as usinas hidráulicas, eólicas e nucleares foi considerado um fator de emissão zero.

O fator de emissão mensal do SIN é a média ponderada dos fatores de emissão de cada hora do mês para os $10 \%$ de geração marginal naquele horário. A ordem de prioridade de despacho foi obtida a partir do Programa Mensal de Operação PMO, elaborado pelo ONS para cada mês, onde são definidas as usinas térmicas despachadas e os correspondentes montantes de geração e as gerações das usinas hidráulicas.

São também informados os custos de operação de cada usina térmica e o custo marginal de operação do SIN. Os valores de geração das usinas são preenchidos de forma ordenada para que possam ser estabelecidas as frações de geração contidas nos $10 \%$ de geração marginal em cada hora.

Para efetuar os cálculos foram considerados os valores verificados para cada hora, pela seguinte ordem: primeiro a geração hidráulica, eólica e nuclear e depois a geração térmica por usina, em ordem crescente de custo.

A seguir apresenta-se um exemplo de cálculo do fator de emissão da margem operacional do SIN elaborado pelo MCT/CIMGC (MCT, 2007 p.12 e 13). Para 
simplificar são considerados, hipoteticamente, dois submercados e apenas um dia de operação.

Exemplo: Passo a passo

1. Na primeira etapa não é considerada a importação do submercado $\mathrm{B}$. $\mathrm{Na}$ linha 1 da Tabela 35, são informados os custos das térmicas, ordenados do menor ao maior custo. Na linha 2 da Tabela 37, são informados os fatores de emissão de cada usina, calculados na 1르 Etapa.

Tabela 35 - 1ํㅡㄹ Etapa do exemplo do cálculo do fator emissão

\begin{tabular}{|c|c|c|c|c|c|c|c|c|c|c|c|c|}
\hline & & 90,89 & 104,5 & 110,48 & 116,1 & 155 & 160,09 & 186,72 & 191,08 & 248,31 & 572 & 1022,1 \\
\hline 0 & 0 & 0 & 1,379845181 & 0,541370383 & 0,86090156 & 1,075921049 & 1,113781919 & 1,009776341 & 1,642395433 & 2,081127034 & 0 & 0 \\
\hline Soma Hidrel & Soma Eólica & Int. B-A & USINA1 & USINA2 & USINA3 & USINA4 & USINA5 & USINA6 & USINA7 & USINA8 & USINA9 & USINA 10 \\
\hline 984,1 & 7,6 & 0,0 & 269,6 & 91,1 & 0,0 & 184,8 & 99,8 & 0,0 & 26,0 & 7,7 & 0,0 & 0,0 \\
\hline 662,0 & 13,6 & 0,0 & 295,3 & 91,0 & 0,0 & 185,5 & 100,4 & 0,0 & 26,3 & 7,8 & 0,0 & 0,0 \\
\hline 509,7 & 15,9 & 0,0 & 295,1 & 91,0 & 0,0 & 185,4 & 100,3 & 0,0 & 26,3 & 7,6 & 0,0 & 0,0 \\
\hline 510,6 & 13,9 & 0,0 & 296,5 & 90,5 & 0,0 & 185,5 & 100,5 & 1,3 & 26,2 & 7,5 & 0,0 & 0,0 \\
\hline 510,4 & 13,5 & 0,0 & 288,2 & 90,5 & 0,0 & 185,2 & 100,7 & 0,0 & 26,1 & 7,5 & 0,0 & 0,0 \\
\hline 512,0 & 14,1 & 0,0 & 299,1 & 90,6 & 0,0 & 185,5 & 100,4 & 0,0 & 25,9 & 7,0 & 0,0 & 0,0 \\
\hline 580,0 & 13,8 & 0,0 & 297,9 & 90,7 & 0,0 & 185,2 & 100,8 & 0,0 & 26,0 & 7,0 & 0,0 & 0,0 \\
\hline 866,6 & 6,8 & 0,0 & 299,9 & 90,9 & 0,0 & 185,1 & 100,7 & 0,0 & 25,9 & 7,0 & 0,0 & 0,0 \\
\hline 1065,9 & 3,5 & 0,0 & 299,4 & 90,7 & 0,0 & 185,3 & 100,6 & 0,0 & 26,0 & 7,2 & 0,0 & 0,0 \\
\hline 1335,7 & 1,0 & 0,0 & 297,8 & 90,6 & 0,0 & 184,9 & 100,4 & 0,0 & 26,2 & 7,3 & 0,0 & 0,0 \\
\hline 1439,0 & 0,0 & 0,0 & 298,7 & 90,6 & 0,0 & 185,6 & 100,3 & 0,0 & 26,2 & 7,1 & 0,0 & 0,0 \\
\hline 1360,1 & 0,0 & 0,0 & 301,9 & 90,5 & 0,0 & 184,6 & 99,9 & 4,9 & 26,3 & 7,5 & 0,0 & 0,0 \\
\hline 1013,1 & 0,0 & 0,0 & 304,1 & 90,6 & 0,0 & 185,3 & 100,1 & 5,9 & 26,3 & 7,1 & 0,0 & 0,0 \\
\hline 886,9 & 0,0 & 0,0 & 302,8 & 90,9 & 0,0 & 185,2 & 99,8 & 6,3 & 26,3 & 7,3 & 0,0 & 0,0 \\
\hline 1212,9 & 0,0 & 0,0 & 301,4 & 90,9 & 0,0 & 185,2 & 99,8 & 6,3 & 26,3 & 7,4 & 0,0 & 0,0 \\
\hline 3152,1 & 0,0 & 0,0 & 299,4 & 90,7 & 0,0 & 184,7 & 99,5 & 6,5 & 26,1 & 7,1 & 0,0 & 0,0 \\
\hline 2566,9 & 0,0 & 0,0 & 295,9 & 90,7 & 0,0 & 184,7 & 99,2 & 6,5 & 26,0 & 6,8 & 0,0 & 0,0 \\
\hline 3104,9 & 0,0 & 0,0 & 296,0 & 90,9 & 0,0 & 184,8 & 99,8 & 6,5 & 26,1 & 7,1 & 0,0 & 0,0 \\
\hline 4483,4 & 0,1 & 0,0 & 301,3 & 90,9 & 0,0 & 184,1 & 99,7 & 6,5 & 25,9 & 6,1 & 0,0 & 0,0 \\
\hline 2660,8 & 0,6 & 0,0 & 299,5 & 91,1 & 0,0 & 183,9 & 99,3 & 6,5 & 26,0 & 6,2 & 0,0 & 0,0 \\
\hline 1942,4 & 0,7 & 0,0 & 303,8 & 91,1 & 0,0 & 183,9 & 99,8 & 6,6 & 26,0 & 6,4 & 0,0 & 0,0 \\
\hline 1544,7 & 0,0 & 0,0 & 304,7 & 90,8 & 0,0 & 183,9 & 99,8 & 6,4 & 26,0 & 6,4 & 0,0 & 0,0 \\
\hline 940,8 & 0,1 & 0,0 & 303,1 & 90,8 & 0,0 & 183,8 & 99,3 & 6,4 & 26,1 & 7,3 & 0,0 & 0,0 \\
\hline 599,5 & 2,0 & 0,0 & 303,2 & 91,0 & 0,0 & 183,9 & 99,4 & 6,5 & 26,2 & 7,0 & 0,0 & 0,0 \\
\hline
\end{tabular}

Fonte: MCT, 2007, p.12

2. Uma vez preenchidas as colunas de geração verificada (hidráulicas, eólicas, nucleares e térmicas), podem ser determinados os $10 \%$ superiores da curva de prioridade de despacho (coluna laranja). Esses $10 \%$ serão então atribuídos às usinas por ordem decrescente (Usina 10, Usina 9, etc.) até completar os $10 \%$ de energia (para primeira hora: 167,1 $\mathrm{MWh}$ ). O fator de emissão para esta hora é a soma ponderada do produto da geração de cada uma dessas usinas pelo fator de emissão das mesmas. O fator de emissão horária do submercado $A$ encontra-se na coluna cinza da Tabela 36. 
Tabela 36 - 2ª Etapa do exemplo do cálculo do fator emissão

\begin{tabular}{|c|c|c|c|c|c|c|c|c|c|c|c|c|}
\hline 1,379845181 & 0,541370383 & 0,86090156 & 1,075921049 & 1,113781919 & 1,009776341 & 1,642395433 & 2,081127034 & 0 & $\overline{0}$ & & & \\
\hline USINA 1 & USINA 2 & USINA3 & USINA 4 & USINA5 & USINA 6 & USINA 7 & USINA8 & USINA9 & USINA 10 & & & \\
\hline 0,0 & 0,0 & 0,0 & 33,6 & 99,8 & 0,0 & 26,0 & 7,7 & 0,0 & 0,0 & 167,1 & 1,233 & 1670,6 \\
\hline 0,0 & 0,0 & 0,0 & 3,7 & 100,4 & 0,0 & 26,3 & 7,8 & 0,0 & 0,0 & 138,2 & 1,288 & 1381,8 \\
\hline 0,0 & 0,0 & 0,0 & 0,0 & 89,2 & 0,0 & 26,3 & 7,6 & 0,0 & 0,0 & 123,1 & 1,286 & 1231,2 \\
\hline 0,0 & 0,0 & 0,0 & 0,0 & 88,2 & 0,0 & 26,2 & 7,5 & 0,0 & 0,0 & 123,2 & 1,284 & 1232,4 \\
\hline 0,0 & 0,0 & 0,0 & 0,0 & 89,6 & 0,0 & 26,1 & 7,5 & 0,0 & 0,0 & 123,2 & 1,285 & 1232,1 \\
\hline 0,0 & 0,0 & 0,0 & 0,0 & 90,6 & 0,0 & 25,9 & 7,0 & 0,0 & 0,0 & 123,4 & 1,279 & 1234,5 \\
\hline 0,0 & 0,0 & 0,0 & 0,0 & 97,2 & 0,0 & 26,0 & 7,0 & 0,0 & 0,0 & 130,1 & 1,271 & 1301,3 \\
\hline 0,0 & 0,0 & 0,0 & 24,7 & 100,7 & 0,0 & 25,9 & 7,0 & 0,0 & 0,0 & 158,3 & 1,237 & 1582,9 \\
\hline 0,0 & 0,0 & 0,0 & 46,0 & 100,6 & 0,0 & 26,0 & 7,2 & 0,0 & 0,0 & 179,9 & 1,219 & 1798,6 \\
\hline 0,0 & 0,0 & 0,0 & 70,5 & 100,4 & 0,0 & 26,2 & 7,3 & 0,0 & 0,0 & 204,4 & 1,203 & 2043,7 \\
\hline 0,0 & 0,0 & 0,0 & 81,1 & 100,3 & 0,0 & 26,2 & 7,1 & 0,0 & 0,0 & 214,7 & 1,196 & 2147,4 \\
\hline 0,0 & 0,0 & 0,0 & 68,9 & 99,9 & 0,0 & 26,3 & 7,5 & 0,0 & 0,0 & 207,8 & 1,201 & 2075,9 \\
\hline 0,0 & 0,0 & 0,0 & 33,9 & 100,1 & 0,0 & 26,3 & 7,1 & 0,0 & 0,0 & 173,8 & 1,223 & 1732,5 \\
\hline 0,0 & 0,0 & 0,0 & 20,8 & 99,8 & 0,0 & 26,3 & 7,3 & 0,0 & 0,0 & 160,5 & 1,235 & 1605,5 \\
\hline 0,0 & 62,7 & 0,0 & 53,2 & 99,8 & 0,0 & 26,3 & 7,4 & 0,0 & 0,0 & 193,0 & 1,209 & 1930,2 \\
\hline 0,0 & 3,5 & 0,0 & 184,7 & 99,5 & 0,0 & 26,1 & 7,1 & 0,0 & 0,0 & 383,6 & 1,055 & 3866,0 \\
\hline 0,0 & 57,6 & 0,0 & 184,7 & 99,2 & 0,0 & 26,0 & 6,8 & 0,0 & 0,0 & 326,7 & 1,147 & 3266,8 \\
\hline 106,8 & 90,9 & 0,0 & 184,8 & 99,8 & 0,0 & 26,1 & 7,1 & 0,0 & 0,0 & 381,8 & 1,061 & 3818,0 \\
\hline 0,0 & 15,5 & 0,0 & 184,1 & 99,7 & 0,0 & 25,9 & 6,1 & 0,0 & 0,0 & 519,8 & 1,091 & 5198,0 \\
\hline 0,0 & 0,0 & 0,0 & 183,9 & 99,3 & 0,0 & 26,0 & 6,2 & 0,0 & 0,0 & 337,4 & 1,123 & 3373,8 \\
\hline 0,0 & 0,0 & 0,0 & 127,3 & 99,8 & 0,0 & 26,0 & 6,4 & 0,0 & 0,0 & 266,1 & 1,168 & 2660,5 \\
\hline 0,0 & 0,0 & 0,0 & 87,6 & 99,8 & 0,0 & 26,0 & 6,4 & 0,0 & 0,0 & 226,8 & 1,184 & 2262,7 \\
\hline 0,0 & 0,0 & 0,0 & 26,7 & 99,3 & 0,0 & 26,1 & 7,3 & 0,0 & 0,0 & 165,8 & 1,229 & 1657,7 \\
\hline 0,0 & 0,0 & 0,0 & 0,0 & 92,2 & 0,0 & 26,2 & 7,0 & 0,0 & 0,0 & 131,9 & 1,265 & 1318,5 \\
\hline
\end{tabular}

Fonte: MCT, 2007, p.12

3. Neste exemplo, o fator de emissão médio da margem de operação do submercado A é 1,176, que é a média ponderada calculada a partir de cada hora. $O$ fator de ponderação aplicado é a geração total para cada hora. $\mathrm{Na}$ segunda fase, Tabela 37 , considera-se a importação de submercados vizinhos, com fator de emissão associado à importação igual ao fator de emissão médio do submercado exportador calculado na primeira fase.

Tabela 37 - 3를 Etapa do exemplo do cálculo do fator emissão

\begin{tabular}{|c|c|c|c|c|c|c|c|c|c|c|c|c|}
\hline & & 90,89 & 104,5 & 110,48 & 116,1 & 155 & 160,09 & 186,72 & 191,08 & 248,31 & 572 & 1022,1 \\
\hline 0 & 0 & 0,157 & 1,379845181 & 0,541370383 & 0,86090156 & 1,075921049 & 1,113781919 & 1,009776341 & 1,642395433 & 2,081127034 & 0 & 0 \\
\hline Soma Hidrel & Soma Eólica & Int. B-A & USINA1 & USINA 2 & USINA3 & USINA4 4 & USINA5 & USINA6 & USINA7 & USINA 8 & USINA9 & USINA 10 \\
\hline 984,1 & 7,6 & 4886,0 & 269,6 & 91,1 & 0,0 & 184,8 & 99,8 & 0,0 & 26,0 & 7,7 & 0,0 & 0,0 \\
\hline 662,0 & 13,6 & 4782,4 & 295,3 & 91,0 & 0,0 & 185,5 & 100,4 & 0,0 & 26,3 & 7,8 & 0,0 & 0,0 \\
\hline 509,7 & 15,9 & 4712,9 & 295,1 & 91,0 & 0,0 & 185,4 & 100,3 & 0,0 & 26,3 & 7,6 & 0,0 & 0,0 \\
\hline 510,6 & 13,9 & 4604,2 & 296,5 & 90,5 & 0,0 & 185,5 & 100,5 & 1,3 & 26,2 & 7,5 & 0,0 & 0,0 \\
\hline 510,4 & 13,5 & 4579,7 & 288,2 & 90,5 & 0,0 & 185,2 & 100,7 & 0,0 & 26,1 & 7,5 & 0,0 & 0,0 \\
\hline 512,0 & 14,1 & 4683,2 & 299,1 & 90,6 & 0,0 & 185,5 & 100,4 & 0,0 & 25,9 & 7,0 & 0,0 & 0,0 \\
\hline 580,0 & 13,8 & 4921,9 & 297,9 & 90,7 & 0,0 & 185,2 & 100,8 & 0,0 & 26,0 & 7,0 & 0,0 & 0,0 \\
\hline 866,6 & 6,8 & 4994,1 & 299,9 & 90,9 & 0,0 & 185,1 & 100,7 & 0,0 & 25,9 & 7,0 & 0,0 & 0,0 \\
\hline 1065,9 & 3,5 & 5250,1 & 299,4 & 90,7 & 0,0 & 185,3 & 100,6 & 0,0 & 26,0 & 7,2 & 0,0 & 0,0 \\
\hline 1335,7 & 1,0 & 5408,0 & 297,8 & 90,6 & 0,0 & 184,9 & 100,4 & 0,0 & 26,2 & 7,3 & 0,0 & 0,0 \\
\hline 1439,0 & 0,0 & 5410,3 & 298,7 & 90,6 & 0,0 & 185,6 & 100,3 & 0,0 & 26,2 & 7,1 & 0,0 & 0,0 \\
\hline 1360,1 & 0,0 & 5443,1 & 301,9 & 90,5 & 0,0 & 184,6 & 99,9 & 4,9 & 26,3 & 7,5 & 0,0 & 0,0 \\
\hline 1013,1 & 0,0 & 5222,7 & 304,1 & 90,6 & 0,0 & 185,3 & 100,1 & 5,9 & 26,3 & 7,1 & 0,0 & 0,0 \\
\hline 886,9 & 0,0 & 5247,3 & 302,8 & 90,9 & 0,0 & 185,2 & 99,8 & 6,3 & 26,3 & 7,3 & 0,0 & 0,0 \\
\hline 1212,9 & 0,0 & 4778,1 & 301,4 & 90,9 & 0,0 & 185,2 & 99,8 & 6,3 & 26,3 & 7,4 & 0,0 & 0,0 \\
\hline 3152,1 & 0,0 & 2828,6 & 299,4 & 90,7 & 0,0 & 184,7 & 99,5 & 6,5 & 26,1 & 7,1 & 0,0 & 0,0 \\
\hline 2566,9 & 0,0 & 2450,5 & 295,9 & 90,7 & 0,0 & 184,7 & 99,2 & 6,5 & 26,0 & 6,8 & 0,0 & 0,0 \\
\hline 3104,9 & 0,0 & 2474,5 & 296,0 & 90,9 & 0,0 & 184,8 & 99,8 & 6,5 & 26,1 & 7,1 & 0,0 & 0,0 \\
\hline 4483,4 & 0,1 & 3777,1 & 301,3 & 90,9 & 0,0 & 184,1 & 99,7 & 6,5 & 25,9 & 6,1 & 0,0 & 0,0 \\
\hline 2660,8 & 0,6 & 5078,1 & 299,5 & 91,1 & 0,0 & 183,9 & 99,3 & 6,5 & 26,0 & 6,2 & 0,0 & 0,0 \\
\hline 1942,4 & 0,7 & 5334,7 & 303,8 & 91,1 & 0,0 & 183,9 & 99,8 & 6,6 & 26,0 & 6,4 & 0,0 & 0,0 \\
\hline 1544,7 & 0,0 & 5248,5 & 304,7 & 90,8 & 0,0 & 183,9 & 99,8 & 6,4 & 26,0 & 6,4 & 0,0 & 0,0 \\
\hline 940,8 & 0,1 & 5210,1 & 303,1 & 90,8 & 0,0 & 183,8 & 99,3 & 6,4 & 26,1 & 7,3 & 0,0 & 0,0 \\
\hline 599,5 & 2,0 & 4914,5 & 303,2 & 91,0 & 0,0 & 183,9 & 99,4 & 6,5 & 26,2 & 7,0 & 0,0 & 0,0 \\
\hline
\end{tabular}

Fonte: MCT, 2007, p.13 
Com a introdução desses novos dados, o resultado final passa a ser de 1,12, apresentado na Tabela 38:

Tabela 38 - 4⿳亠丷厂 Etapa do exemplo do cálculo do fator emissão

\begin{tabular}{|c|c|c|c|c|c|c|c|c|c|c|c|c|}
\hline 1,379845181 & 0,541370383 & 0,86090156 & 1,075921049 & 1,113781919 & 1,009776341 & 1,642395433 & 2,081127034 & $\overline{0}$ & 0 & & & \\
\hline USINA 1 & USINA 2 & USINA3 & USINA 4 & USINA 5 & USINA 6 & USINA 7 & USINA8 & USINA9 & USINA 10 & & & \\
\hline 246,3 & 91,1 & 0,0 & 184,8 & $\begin{array}{ll}99,8 \\
\end{array}$ & $\overline{0,0}$ & 26,0 & 7,7 & 0,0 & 0,0 & 655,7 & 1,156 & 6556,6 \\
\hline 205,5 & 91,0 & 0,0 & 185,5 & 100,4 & 0,0 & 26,3 & 7,8 & 0,0 & 0,0 & 616,4 & 1,141 & 6164,2 \\
\hline 183,8 & 91,0 & 0,0 & 185,4 & 100,3 & 0,0 & 26,3 & 7,6 & 0,0 & 0,0 & 594,4 & 1,132 & 5944,1 \\
\hline 172,3 & 90,5 & 0,0 & 185,5 & 100,5 & 1,3 & 26,2 & 7,5 & 0,0 & 0,0 & 583,7 & 1,127 & 5836,6 \\
\hline 171,2 & 90,5 & 0,0 & 185,2 & 100,7 & 0,0 & 26,1 & 7,5 & 0,0 & 0,0 & 581,2 & 1,127 & 5811,8 \\
\hline 182,5 & 90,6 & 0,0 & 185,5 & 100,4 & 0,0 & 25,9 & 7,0 & 0,0 & 0,0 & 591,8 & 1,131 & 5917,7 \\
\hline 212,7 & 90,7 & 0,0 & 185,2 & 100,8 & 0,0 & 26,0 & 7,0 & 0,0 & 0,0 & 522,3 & 1,143 & 6223,2 \\
\hline 248,1 & 90,9 & 0,0 & 185,1 & 100,7 & 0,0 & 25,9 & 7,0 & 0,0 & 0,0 & 657,7 & 1,156 & 6577,0 \\
\hline 295,0 & 90,7 & 0,0 & 185,3 & 100,6 & 0,0 & 26,0 & 7,2 & 0,0 & 0,0 & 704,9 & 1,171 & 7048,7 \\
\hline 297,8 & 90,6 & 0,0 & 184,9 & 100,4 & 0,0 & 26,2 & 7,3 & 0,0 & 0,0 & 745,2 & 1,120 & 7461,7 \\
\hline 298,7 & 90,6 & 0,0 & 185,6 & 100,3 & 0,0 & 26,2 & 7,1 & 0,0 & 0,0 & 755,8 & 1,108 & 7557,7 \\
\hline 301,9 & 90,5 & 0,0 & 184,8 & 99,9 & 4,9 & 26,3 & 7,5 & 0,0 & 0,0 & 751,9 & 1,124 & 7519,0 \\
\hline 280,3 & 90,5 & 0,0 & 185,3 & 100,1 & 5,9 & 26,3 & 7,1 & 0,0 & 0,0 & 695,5 & 1,165 & 6955,2 \\
\hline 269,5 & 90,9 & 0,0 & 185,2 & 99,8 & 6,3 & 26,3 & 7,3 & 0,0 & 0,0 & 685,3 & 1,162 & 6862,8 \\
\hline 254,9 & 90,9 & 0,0 & 185,2 & 99,8 & 6,3 & 26,3 & 7,4 & 0,0 & 0,0 & 670,8 & 1,157 & 6708,3 \\
\hline 254,9 & 90,7 & 0,0 & 184,7 & 99,5 & 6,5 & 26,1 & 7,1 & 0,0 & 0,0 & 669,5 & 1,157 & 6694,6 \\
\hline 157,8 & 90,7 & 0,0 & 184,7 & 99,2 & 6,5 & 26,0 & 6,8 & 0,0 & 0,0 & 571,7 & 1,119 & 5717,3 \\
\hline 214,2 & 90,9 & 0,0 & 184,8 & 99,8 & 6,5 & 26,1 & 7,1 & 0,0 & 0,0 & 629,2 & 1,142 & 6292,5 \\
\hline 301,3 & 90,9 & 0,0 & 184,1 & 99,7 & 6,5 & 25,9 & 6,1 & 0,0 & 0,0 & 879,5 & 0,963 & 8975,1 \\
\hline 299,5 & 91,1 & 0,0 & 183,9 & 99,3 & 6,5 & 26,0 & 6,2 & 0,0 & 0,0 & 845,2 & 1,010 & 8451,9 \\
\hline 303,8 & 91,1 & 0,0 & 183,9 & 99,8 & 6,6 & 26,0 & 6,4 & 0,0 & 0,0 & 799,5 & 1,067 & 7995,2 \\
\hline 304,7 & 90,8 & 0,0 & 183,9 & 99,8 & 6,4 & 26,0 & 6,4 & 0,0 & 0,0 & 751,1 & 1,127 & 7511,3 \\
\hline 273,0 & 90,8 & 0,0 & 183,8 & 99,3 & 6,4 & 26,1 & 7,3 & 0,0 & 0,0 & 686,8 & 1,163 & 6867,8 \\
\hline 209,4 & 91,0 & 0,0 & 183,9 & 99,4 & 6,5 & 26,2 & 7,0 & 0,0 & 0,0 & 623,3 & 1,140 & 6233,0 \\
\hline
\end{tabular}

Fonte: MCT, 2007, p.13

A.6.2 Determinação do Fator de Emissão da Margem de Construção

O fator de emissão da margem de construção (BM) é o fator médio do conjunto de usinas mais novas do SIN. Esse conjunto contém, no mínimo, cinco usinas e sua capacidade instalada deve ser maior que $20 \%$ da capacidade instalada do SIN.

Ele foi calculado, a partir dos valores de geração anual de cada usina que compõe o conjunto acima mencionado no ano anterior ao da entrada da atividade do projeto e dos fatores de emissão de $\mathrm{CO}_{2}$ de cada usina termelétrica. As usinas são ordenadas em ordem crescente de data de entrada em operação, sendo selecionadas aquelas mais novas responsáveis por mais de $20 \%$ da geração anual do SIN. A equação A. 4 foi aplicada.

A seguir apresenta-se um exemplo de cálculo do fator de emissão da margem de construção do SIN elaborado pelo manual de Cálculo (MCT, 2007, p.14). 
Exemplo: passo a passo

A Tabela A.5 apresenta o procedimento para calcular o Fator de Emissão da Margem de Construção para um sistema elétrico hipotético que teve uma geração total de 12.000.000 MWh no ano.

A parcela de $20 \%$ deste total é igual a 2.400.000 MWh. As usinas são ordenadas em ordem crescente de data de entrada em operação, levando em consideração o início de testes de comissionamento da primeira unidade da usina.

No exemplo, oito usinas foram suficientes para complementar os $20 \%$ do total da geração do sistema elétrico hipotético. Os valores de Rjy são calculados a partir do histórico de entrada em operação das usinas. Rjy $=1$ se parte ou o total da geração da usina está contida nos $20 \%$ da geração total correspondente às usinas mais novas e $R j y=0$ se a usina não está contida nos $20 \%$ da geração total correspondente às usinas mais novas.

O Fator de Emissão de Margem de Construção calculado é de 0, 2853 $\mathrm{TCO}_{2} / \mathrm{MWh}$, Tabela 39.

Tabela 39 - Exemplo do cálculo do fator de emissão da margem de construção

\begin{tabular}{|c|c|c|c|c|c|c|c|c|c|}
\hline & USINA 1 & USINA 2 & USINA 3 & USINA 4 & USINA 5 & USINA 6 & USINA 7 & USINA 8 & \\
\hline$G_{i(y-1)}$ & $540.000,00$ & $65.000,00$ & $26.300,00$ & $440.500,00$ & $248.000,00$ & $361.200,00$ & $409.000,00$ & $520.000,00$ & \\
\hline $\mathbf{F T}_{j(y-1)}$ & 0 & 0 & 0 & 0,705 & 0 & 0,458 & 0,657 & 0 & \\
\hline $\mathbf{R}_{\mathrm{j}(\mathrm{y}-1)}$ & 1 & 1 & 1 & 1 & 1 & 1 & 1 & 1 & \\
\hline Soma $\left(R^{*} F T^{*} G\right)$ & - & - & - & $310.552,50$ & - & $165.429,60$ & $268.713,00$ & - & $744.695,10$ \\
\hline Soma $\left(R^{*} G\right)$ & $540.000,00$ & $65.000,00$ & $26.300,00$ & $440.500,00$ & $248.000,00$ & $361.200,00$ & $409.000,00$ & $520.000,00$ & $2.610 .000,00$ \\
\hline
\end{tabular}

Fonte: MCT, 2007, p.14 


\section{A.7 Análise dos Resultados}

Os resultados da aplicação do método $c$ da metodologia para determinar o fator de emissão de sistema elétrico médio para 2006 e 2007 são apresentados na Tabela 40. O fator de emissão do SIN para 2008 só poderá ser calculado no início de 2009, após ser divulgado o fator de emissão da margem de construção.

Tabela 40 - Fatores de emissão médios anuais do SIN calculados pela CIMGC

\begin{tabular}{cccc}
\hline ANO & $\left(\mathrm{FE}_{\text {grid,om })}\right.$ & $\left(\mathrm{FE}_{\text {gridBM }}\right)$ & $\left(\mathrm{FE}_{\text {gridcm }}\right)$ \\
$(\mathbf{1})$ & $\mathbf{( 2 )}$ & $\mathbf{( 3 )}$ & $\mathbf{( 4 )}$ \\
\hline 2006 & 0,3232 & 0,0814 & 0,2023 \\
2007 & 0,2909 & 0,0775 & 0,1842 \\
\hline
\end{tabular}

Observe-se que os valores calculados da linha de base do SIN, em 2006 e 2007, coluna 4 da Tabela 42, de 0,2023 tCO $/ \mathrm{MWh}_{2}$ e 0,1842 $\mathrm{tCO}_{2} / \mathrm{MWh}$, respectivamente não permitem aos proponentes de projetos de MDL avaliarem como será o comportamento futuro da linha de base do SIN.

O problema da aplicação desse método de cálculo é que, embora seja muito acurado para identificar o que já ocorreu e/ou está ocorrendo no presente, ele não sinaliza em relação ao futuro, sendo exatamente essa sinalização um dos elementos que mais precisam os formuladores de política e os proponentes de projetos de MDL no Brasil.

Com efeito, os cenários projetados para a configuração futura do mix das usinas que fornecerão eletricidade para o SIN e que comporão o topo das usinas que provavelmente serão deslocadas com a entrada das atividades de um projeto MDL, em curto e médio prazo, apontam para uma crescente inserção das usinas térmicas convencionais, emissoras dos GEE. Essa tendência não é revelada, considerando simplesmente os fatores de emissões da margem combinada apresentados acima. 
Em termos mais concretos: é razoável calcular as reduções de emissões de um projeto de MDL a ser conectado ao SIN, considerando o valor de 0,1842 $\mathrm{tCO}_{2} / \mathrm{MWh}$ ou deveria ser adotado outro valor? A resposta a essa questão depende da avaliação que o proponente do projeto faça em relação ao comportamento futuro da linha de base, visto que esta será anualmente monitorada e as reduções das emissões associadas às atividades do projeto MDL revisadas.

Por outro lado, a margem operacional registra valores elevados do fator de emissão em 2006 e 2007, demonstrando que o despacho real das usinas térmicas convencionais, em função da política operativa do SIN, tem sido muito mais intenso do que seria razoável imaginar, caso a margem de construção calculada refletisse as condições operacionais futuras do SIN. Ressalte-se que os fatores de emissões mensais da margem operacional para o primeiro semestre de 2008 apontam para o aprofundamento dessa inversão de sinalização em relação ao comportamento futuro do despacho térmico convencional.

Adotar valores da linha de base mais conservadores, embora seja uma opção recomendada para evitar projeções superestimadas de reduções das emissões de um projeto de MDL precisa ser adequadamente avaliada para não desestimular o desenvolvimento de novos projetos. Por essa razão, fortalece-se a necessidade do desenvolvimento de novos referenciais metodológicos, que sem desconhecer o peso e a importância do comportamento observado das emissões, também indiquem, por meio da aplicação de modelos de simulação, ou de quaisquer outros métodos, as prováveis trajetórias futuras dessas emissões. 
APÊNDICE B - Parque hidrelétrico atual e cenário de expansão das hidrelétricas

\begin{tabular}{|c|c|c|c|c|c|c|c|}
\hline & Nome do Empreendimento & Bacia & & Região & Instalado & Expansão & A partir de \\
\hline 1 & 14 de Julho & Das Antas & RS & Sul & 0 & 100 & Mar./09 \\
\hline 2 & Água Limpa & Das Mortes & MT & Sudeste & 0 & 320 & Jan./13 \\
\hline 3 & Água Vermelha & Grande & SP/MG & Sudeste & 1.396 & 0 & Jan./07 \\
\hline 4 & Aimorés & Doce & MG & Sudeste & 330 & 0 & Jan./07 \\
\hline 5 & Amador Aguiar I (ex-Capim Branco) & Araguai & MG & Sudeste & 240 & 0 & Jan./07 \\
\hline 6 & Amador Aguiar II (ex-Capim Branco) & Araguai & MG & Sudeste & 0 & 210 & Mar./07 \\
\hline 7 & Assis Chateubriand (Salto Mimoso) & & MS & Sudeste & 30 & 0 & Jan./07 \\
\hline 8 & Baguari & Doce & MG & Sudeste & 0 & 140 & Set./09 \\
\hline 9 & Baixo Iguaçu & Iguaçu & PR & Sul & 0 & 350,1 & Jan./14 \\
\hline 10 & Balbina & Uatumã & AM & Norte & 0 & 250 & Jan./12 \\
\hline 11 & Bariri (Álvaro Souza Lima) & Tietê & SP & Sudeste & 143,1 & 0 & Jan./07 \\
\hline 12 & Barra Bonita & Tietê & SP & Sudeste & 140,78 & 0 & Jan./07 \\
\hline 13 & Barra do Braúna & Pomba & MG & Sudeste & 0 & 39 & Mai./09 \\
\hline 14 & Barra do Pomba & Paraíba do Sul & RJ & Sudeste & 0 & 80 & Jan./13 \\
\hline 15 & Barra dos Coqueiros & Claro & GO & Sudeste & 0 & 90 & Abr./10 \\
\hline 16 & Barra Grande & Pelotas & $\mathrm{RS} / \mathrm{SC}$ & Sul & 698,25 & 0 & Jan./07 \\
\hline 17 & Batalha & São Marcos & GO/MG & Sudeste & 0 & 52,5 & Jul./09 \\
\hline 18 & Baú I & Doce & MG & Sudeste & 0 & 110,1 & Mar./10 \\
\hline 29 & Belo Monte & Xingu & PA & Norte & 0 & 5500 & Jan./14 \\
\hline 20 & Belo Monte Complementar & Xingu & PA & Norte & 0 & 181,3 & Jan./13 \\
\hline 21 & Boa Esperança & Parnaíba & $\mathrm{PI} / \mathrm{MA}$ & Nordeste & 237,3 & 0 & Jan./07 \\
\hline 22 & Buriti Queimado & Das Almas & GO & Sudeste & 0 & 142 & Dez./16 \\
\hline 23 & Cachoeira & Parnaíba & $\mathrm{PI} / \mathrm{MA}$ & Nordeste & 0 & 96 & Jan./16 \\
\hline 24 & Cachoeira Dourada & Paranaíba & GO & Sudeste & 656 & 0 & Jan./07 \\
\hline 25 & Cachoeirão & Jurena & MT & Sudeste & 0 & 64 & Jan./13 \\
\hline 26 & Cachoeirinha & Chopim & PR & Sul & 0 & 42,5 & Jan./12 \\
\hline 27 & Caconde & Pardo & SP & Sudeste & 80 & 0 & Jan./07 \\
\hline 28 & Caçu & Claro & GO & Sudeste & 0 & 65 & Abr./10 \\
\hline 29 & Camargos & Grande & MG & Sudeste & 46 & 0 & Jan./07 \\
\hline 30 & Cambuci & Paraíba do Sul & RJ & Sudeste & 0 & 50 & Jan./14 \\
\hline 31 & Campos Novos & Canoas & SC & Sul & 0 & 880 & Mar./07 \\
\hline 32 & Cana Brava & Tocantins & GO & Sudeste & 465,9 & 0 & Jan./07 \\
\hline 33 & Canoas I & Paranapanema & SP/PR & Sudeste & 82,5 & 0 & Jan./07 \\
\hline
\end{tabular}




\section{Continuação}

\begin{tabular}{|c|c|c|c|c|c|c|c|}
\hline & Nome do Empreendimento & Bacia & & Região & Instalado & Expansão & A partir de \\
\hline 34 & Canoas II & Paranapanema & SP/PR & Sudeste & 72 & 0 & Jan./07 \\
\hline 35 & Capivara & Paranapanema & SP/PR & Sudeste & 640 & 0 & Jan./07 \\
\hline 36 & Castelhano & Parnaíba & $\mathrm{PI} / \mathrm{MA}$ & Nordeste & 0 & 96 & Jan./16 \\
\hline 37 & Castro Alves & Das Antas & RS & Sul & 0 & 129,9 & Dez./07 \\
\hline 38 & Cebolão & Tibagi & PR & Sul & 0 & 155 & Dez./16 \\
\hline 39 & Chavantes & Paranapanema & SP/PR & Sudeste & 414 & 0 & Jan./07 \\
\hline 40 & Colider & Teles Pires & MT & Sudeste & 0 & 342 & Fev./15 \\
\hline 42 & Corumbá I & Corumbá & $\mathrm{GO}$ & Sudeste & 375 & 0 & Jan./07 \\
\hline 43 & Corumbá III & Corumbá & $\mathrm{GO}$ & Sudeste & 0 & 93,6 & Fev./09 \\
\hline 44 & Corumbá IV & Corumbá & $\mathrm{GO}$ & Sudeste & 127 & 0 & Jan./07 \\
\hline 45 & Curuá-Uma & Curuá-Uma & PA & Norte & 30,3 & 0 & Jan./07 \\
\hline 46 & Dardanelos & Aripuanã & MT & Sudeste & 0 & 264 & Jan./11 \\
\hline 47 & Dona Francisca & Jacui & $\mathrm{RS}$ & Sul & 125 & 0 & Jan./07 \\
\hline 48 & Emborcação & Paranaíba & MG & Sudeste & 1.192 & 0 & Jan./07 \\
\hline 49 & Espora & Correntes & $\mathrm{GO}$ & Sudeste & 32,01 & 0 & Jan./07 \\
\hline 50 & Estreito & Grande & SP/MG & Sudeste & 1.050 & 0 & Jan./07 \\
\hline 52 & Estreito Tocantins & Tocantins & $\mathrm{TO} / \mathrm{MA}$ & Norte & 0 & 814,8 & Ago./10 \\
\hline 53 & Euclides da Cunha & Pardo & SP & Sudeste & 108,8 & 0 & Jan./07 \\
\hline 54 & Fontes Nova & Piraí & RJ & Sudeste & 130,3 & 0 & Jan./07 \\
\hline 55 & Foz do Apiaçás & Teles Pires & MT & Sudeste & 0 & 275 & Abr./15 \\
\hline 56 & Foz do Chapecó & Uruguai & $\mathrm{RS} / \mathrm{SC}$ & Sul & 0 & 855,2 & Ago./10 \\
\hline 57 & Foz do Rio Claro & Claro & $\mathrm{GO}$ & Sudeste & 0 & 68,4 & Jun./10 \\
\hline 58 & Fundão & Jordão & PR & Sul & 120,168 & 0 & Jan./07 \\
\hline 59 & Funil & Paraíba do Sul & RJ & Sudeste & 216 & 0 & Jan./07 \\
\hline 60 & Funil-Grande & Grande & MG & Sudeste & 180 & 0 & Jan./07 \\
\hline 61 & Furnas & Grande & MG & Sudeste & 1.216 & 0 & Jan./07 \\
\hline 62 & Garibaldi & Canoas & SC & Sul & 0 & 150 & Jan./13 \\
\hline 63 & Governador Bento Munhoz Rocha Neto & Iguaçu & PR & Sul & 1.676 & 0 & Jan./07 \\
\hline 64 & Governador José Richa (Salto Caxias) & Iguaçu & PR & Sul & 1.240 & 0 & Jan./07 \\
\hline 65 & Governador Ney Aninthas de Barros Braga (Segredo) & Iguaçu & PR & Sul & 1.260 & 0 & Jan./07 \\
\hline 66 & Governador Parigot de Souza & Capivari & PR & Sul & 260 & 0 & Jan./07 \\
\hline 67 & Guaporé & Guaporé & MT & Sudeste & 124,2 & 0 & Jan./07 \\
\hline
\end{tabular}


Continuação

\begin{tabular}{|c|c|c|c|c|c|c|c|}
\hline & Nome do Empreendimento & Bacia & & Região & Instalado & Expansão & A partir de \\
\hline 68 & Guilman-Amorim & Piracicaba & MG & Sudeste & 140,04 & 0 & Jan./07 \\
\hline 69 & Henry Borden & Pedras & SP & Sudeste & 889 & 0 & Jan./07 \\
\hline 70 & Ibitinga & Tietê & SP & Sudeste & 131,49 & 0 & Jan./07 \\
\hline 71 & Igarapava & Grande & MG/SP & Sudeste & 210 & 0 & Jan./07 \\
\hline 72 & Ilha dos Pombos & Paraíba do Sul & RJ & Sudeste & 187,169 & 0 & Jan./07 \\
\hline 73 & Ilha Solteira Equivalente & Paraná & $\mathrm{SP} / \mathrm{MG}$ & Sudeste & 3.444 & 0 & Jan./07 \\
\hline 74 & Irapé & Jequitinhonha & MG & Sudeste & 360 & 0 & Jan./07 \\
\hline 76 & Itaguaçu & Claro & $\mathrm{GO}$ & Sudeste & 0 & 130 & Set./13 \\
\hline 77 & Itaipu $(50 \mathrm{~Hz})$ & Iguaçu & - & Itaipu & 5.601 & 0 & Jan./07 \\
\hline 78 & Itaipu $(60 \mathrm{~Hz})$ & Iguaçu & - & Itaipu & 6.650 & 700 & Jun./07 \\
\hline 79 & Itapebi & Jequitinhonha & BA & Nordeste & 450 & 0 & Jan./07 \\
\hline 80 & Itapiranga & Uruguai & $\mathrm{SC} / \mathrm{RS}$ & Sul & 0 & 724,6 & Jan./14 \\
\hline 81 & Itaúba & Jacui & RS & Sul & 512,4 & 0 & Jan./07 \\
\hline 82 & Itiquira I & Itiquira & $\mathrm{MT}$ & Sudeste & 61 & 0 & Jan./07 \\
\hline 83 & Itiquira II & Itiquira & MT & Sudeste & 95 & 0 & Jan./07 \\
\hline 84 & Itumbiara & Paranaíba & GO/MG & Sudeste & 2.290 & 0 & Jan./07 \\
\hline 86 & Jacui & Jacui & RS & Sul & 180 & 0 & Jan./07 \\
\hline 87 & Jaguara & Grande & MG/SP & Sudeste & 424 & 0 & Jan./07 \\
\hline 88 & Jaguari & Jaguari & SP & Sudeste & 27,6 & 0 & Jan./07 \\
\hline 89 & Jataizinho & Tibagi & PR & Sul & 0 & 155 & Dez./16 \\
\hline 90 & Jauru & Jauru & MT & Sudeste & 121,5 & 0 & Jan./07 \\
\hline 91 & Jirau & Madeira & RO & Norte & 0 & 3300 & Mar./13 \\
\hline 92 & Jupiá & Paraná & SP/MS & Sudeste & 1.551 & 0 & Jan./07 \\
\hline 93 & Juruena & Juruena & MT & Sudeste & 0 & 46 & Jan./13 \\
\hline 94 & Jurumirim (Armando Aavenllanal Laydner) & Paranapanema & SP & Sudeste & 97,7 & 0 & Jan./07 \\
\hline 95 & Limoeiro (Armando Salles de Oliveira) & Pardo & SP & Sudeste & 32 & 0 & Jan./07 \\
\hline 96 & Luiz Eduardo Magalhães (Lajeado) & Tocantins & TO & Sudeste & 902,5 & 0 & Jan./07 \\
\hline 97 & Luiz Gonzaga (Itaparica) & São Francisco & PE/BA & Nordeste & 1.480 & 0 & Jan./07 \\
\hline 98 & Machadinho & Pelotas & $\mathrm{RS} / \mathrm{SC}$ & Sul & 1.140 & 0 & Jan./07 \\
\hline 99 & Magessi & Teles Pires & MT & Sudeste & 0 & 53 & Abr./15 \\
\hline 100 & Manso & Manso & MT & Sudeste & 210,9 & 0 & Jan./07 \\
\hline 101 & Marabá & Tocantins & PA & Norte & 0 & 2160 & Dez./14 \\
\hline
\end{tabular}


Continuação

\begin{tabular}{|c|c|c|c|c|c|c|c|}
\hline & Nome do Empreendimento & Bacia & & Região & Instalado & Expansão & A partir de \\
\hline 102 & Maranhão Baixo & Maranhão & $\mathrm{GO}$ & Sudeste & 0 & 124,8 & Dez./16 \\
\hline 103 & Marimbondo & Grande & MG/SP & Sudeste & 1.440 & 0 & Jan./07 \\
\hline 104 & Mascarenhas & Doce & MG & Sudeste & 180,5 & 0 & Jan./07 \\
\hline 105 & Mascarenhas de Moraes & Grande & MG & Sudeste & 476 & 0 & Jan./07 \\
\hline 106 & Mauá + PCH & Tibagi & PR & Sul & 0 & 361 & Jan./11 \\
\hline 107 & Mirador & Tocantinzinho & $\mathrm{GO}$ & Sudeste & 0 & 80 & Out./14 \\
\hline 108 & Miranda & Araguari & MG & Sudeste & 408 & 0 & Jan./07 \\
\hline 110 & Monte Claro & Das Antas & RS & Sul & 130 & 0 & Jan./07 \\
\hline 111 & Murta & Jequitinhonha & MG & Sudeste & 0 & 120 & Jan./15 \\
\hline 112 & Nilo Peçanha & Ribeirão das Lajes & RJ & Sudeste & 378,42 & 0 & Jan./07 \\
\hline 113 & Nova Avanhandava & Tietê & SP & Sudeste & 347,4 & 0 & Jan./07 \\
\hline 114 & Nova Ponte & Araguari & MG & Sudeste & 510 & 0 & Jan./07 \\
\hline 115 & Novo Acordo & Sono/Médio Tocantins & TO & Sudeste & 0 & 160 & Jan./14 \\
\hline 116 & Olho d'água & Correntes & $\mathrm{GO}$ & Sudeste & 0 & 33 & Jul./09 \\
\hline 117 & Ourinhos & Paranapanema & SP/PR & Sudeste & 44 & 0 & Jan./07 \\
\hline 118 & Pai Querê & Pelotas & $\mathrm{RS} / \mathrm{SC}$ & Sul & 0 & 291,9 & Jan./12 \\
\hline 120 & Paranhos & Chopim & PR & Sul & 0 & 62,6 & Jan./16 \\
\hline 121 & Passo de São João & ljui & $\mathrm{RS}$ & Sul & 0 & 77 & Set./09 \\
\hline 122 & Passo Fundo & Passo Fundo & RS & Sul & 226 & 0 & Jan./07 \\
\hline 123 & Passo Real & Jacuí & $\mathrm{RS}$ & Sul & 158 & 0 & Jan./07 \\
\hline 124 & Pedra Branca & São Francisco & $\mathrm{BA} / \mathrm{PE}$ & Nordeste & 0 & 440 & Dez./16 \\
\hline 125 & Pedra do Cavalo & Paraguaçu & $\mathrm{BA}$ & Nordeste & 162 & 0 & Jan./07 \\
\hline 126 & Peixe Angical & Tocantins & TO & Sudeste & 498,75 & 0 & Jan./07 \\
\hline 127 & Pereira Passos & Lajes & RJ & Sudeste & 99,11 & 0 & Jan./07 \\
\hline 128 & Picada & Peixe & $M G$ & Sudeste & 50 & 0 & Jan./07 \\
\hline 129 & Pirajú & Paranapanema & $\mathrm{SP}$ & Sudeste & 81 & 0 & Jan./07 \\
\hline 130 & Ponte Pedra & Correntes & $\mathrm{MS} / \mathrm{MT}$ & Sudeste & 176,1 & 0 & Jan./07 \\
\hline 131 & Porto Colômbia & Grande & MG/SP & Sudeste & 320 & 0 & Jan./07 \\
\hline 132 & Porto Estrela & Santo Antônio & MG & Sudeste & 112,022 & 0 & Jan./07 \\
\hline 133 & Porto Galeano & Sucuriú & MS & Sudeste & 0 & 139 & Jan./14 \\
\hline 134 & Porto Primavera & Paraná & SP/MS & Sudeste & 1.540 & 0 & Jan./07 \\
\hline 135 & Promissão & Tietê & SP & Sudeste & 264 & 0 & Jan./07 \\
\hline
\end{tabular}


Continuação

\begin{tabular}{|c|c|c|c|c|c|c|c|}
\hline & Nome do Empreendimento & Bacia & & Região & Instalado & Expansão & A partir de \\
\hline 136 & Quebra Queixo & Chapecó & SC & Sul & 120 & 0 & Jan./07 \\
\hline 137 & Queimado & Preto & MG/GO & Sudeste & 105 & 0 & Jan./07 \\
\hline 139 & Riacho Seco & São Francisco & $\mathrm{BA} / \mathrm{PE}$ & Nordeste & 0 & 330 & Dez./16 \\
\hline 140 & Ribeiro Gonçalves & Parnaíba & $\mathrm{PI} / \mathrm{MA}$ & Nordeste & 0 & 173 & Fev./13 \\
\hline 141 & Risoleta Neves (Candonga) & Doce & MG & Sudeste & 140 & 0 & Jan./07 \\
\hline 142 & Rondon II & Comemoração & RO & Norte & 0 & 73,5 & Jan./09 \\
\hline 144 & Rosana & Paranapanema & SP/PR & Sudeste & 372 & 0 & Jan./07 \\
\hline 145 & Sá Carvalho & Piracicaba & MG & Sudeste & 78 & 0 & Jan./07 \\
\hline 146 & Salto & Verde & GO & Sudeste & 0 & 108 & Dez./09 \\
\hline 147 & Salto do Rio Verdinho & Verde & GO & Sudeste & 0 & 93 & Dez./09 \\
\hline 148 & Salto Grande & Santo Antonio & MG & Sudeste & 102 & 0 & Jan./07 \\
\hline 149 & Salto Grande & Chopim & PR & Sul & 70 & 0 & Jan./07 \\
\hline 150 & Salto Osório & Iguaçu & PR & Sul & 1.078 & 0 & Jan./07 \\
\hline 151 & Salto Pilão & Itajaí & SC & Sul & 0 & 182,4 & Fev./10 \\
\hline 152 & Salto Santiago & Iguaçu & PR & Sul & 1.420 & 0 & Jan./07 \\
\hline 154 & Santa Branca & Paraíba do Sul & SP & Sudeste & 56,05 & 0 & Jan./07 \\
\hline 155 & Santa Clara MG & Mucuri & MG/BA & Sudeste & 60 & 0 & Jan./07 \\
\hline 156 & Santa Clara PR & Jordão & PR & Sul & 120,168 & 0 & Jan./07 \\
\hline 157 & Santo Antonio & Madeira & RO & Madeira & 0 & 3150,4 & Abr./12 \\
\hline 158 & São Domingos & Verde & MS & Sudeste & 0 & 48 & Jan./12 \\
\hline 159 & São João & Chopim & PR & Sul & 0 & 62,5 & Mar./12 \\
\hline 160 & São José & ljuí & RS & Sul & 0 & 51 & Abr./09 \\
\hline 161 & São Manoel & Teles Pires & MT & Sudeste & 0 & 746 & Jan./15 \\
\hline 162 & São Miguel & Grande & MG & Sudeste & 0 & 64,5 & Jan./16 \\
\hline 163 & São Roque & Canoas & SC & Sul & 0 & 214 & Jan./13 \\
\hline 164 & São Salvador & Tocantins & $\mathrm{TO} / \mathrm{GO}$ & Sudeste & 0 & 243,2 & Jan./11 \\
\hline 165 & São Simão & Paranaíba & MG/GO & Sudeste & 1.710 & 0 & Jan./07 \\
\hline 166 & Serra da Mesa & Tocantins & GO & Sudeste & 1.275 & 0 & Jan./07 \\
\hline 167 & Serra do Facão & São Marcos & $\mathrm{GO} / \mathrm{MG}$ & Sudeste & 0 & 212,58 & Out./10 \\
\hline 168 & Serra Quebrada & Tocantins & TO/MA & Norte & 0 & 1328 & Jan./13 \\
\hline 169 & Simplício + PCH & Paraíba do Sul & MG/RJ & Sudeste & 0 & 333,7 & Dez./10 \\
\hline 170 & Sinop & Teles Pires & MT & Sudeste & 0 & 461,1 & Jul./14 \\
\hline 171 & Sobradinho & São Francisco & $\mathrm{BA}$ & Nordete & 1.050 & 0 & Jan./07 \\
\hline
\end{tabular}




\section{Conclusão}

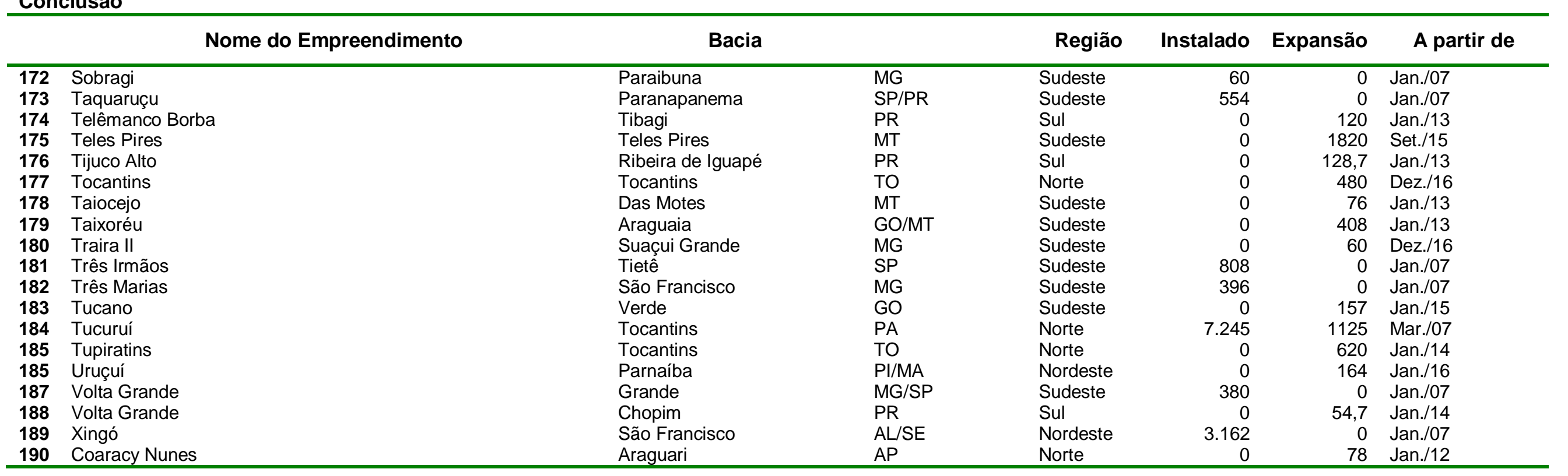




\section{APÊNDICE C.1 - Parque termelétrico atual e expansão - SUDESTE / CENTRO-OESTE}

\begin{tabular}{|c|c|c|c|c|c|c|c|c|c|c|c|c|c|c|c|}
\hline & \multirow[b]{2}{*}{$\begin{array}{l}\text { Nome do } \\
\text { Empreendimento }\end{array}$} & \multirow[b]{2}{*}{ Combustível } & \multicolumn{2}{|c|}{ Preço } & \multicolumn{3}{|c|}{ Capacidade (MWmed) } & \multicolumn{2}{|c|}{ Expansão 1} & \multicolumn{2}{|c|}{ Expansão 2} & \multicolumn{2}{|c|}{ Expansão 3} & \multicolumn{2}{|c|}{ Expansão 4} \\
\hline & & & Piso & Evolução & Instalado & Inflexível & Disponível & Data & MWFlex & Data & MWFlex & Data & MWFlex & Data & MWFlex \\
\hline 1 & $\begin{array}{l}\text { Aureliano Chaves } \\
\text { (Ibirité) }\end{array}$ & GN & 77 & const & 0 & 0 & 0 & Jul./09 & 201,59 & & 0 & & & & \\
\hline 2 & $\begin{array}{l}\text { Barbosa Lima Sobrinho } \\
\text { (Eletrobolt) }\end{array}$ & GN & 139 & const & 21,225 & 0 & 21 & Jan./08 & 137,275 & Jul./08 & 73,15 & Jan./09 & 74,1 & & \\
\hline 3 & Cubatão & GN & 200 & const & 0 & 0 & 0 & Jan./10 & 183,35 & & 0 & & & & \\
\hline 4 & Do Atlântico 1 & GN & 201 & Const & 0 & 0 & 0 & Jan./11 & 465,5 & & 0 & & & & \\
\hline 5 & $\begin{array}{l}\text { Fernando Gasparian (N. } \\
\text { Piratininga) }\end{array}$ & GN & 180 & Const & 0 & 0 & 0 & Jan./09 & 247,855 & Jan./10 & 247,76 & & & & \\
\hline 6 & $\begin{array}{l}\text { Gov. Leonel Brizola } \\
\text { (Termorio) }\end{array}$ & GN & 137 & Const & 388,835 & 34,01 & 355 & Jul./08 & 59,28 & Jan./09 & 499,985 & & & & \\
\hline 7 & Juiz de Fora & GN & 150 & Const & 75,05 & 0 & 75 & & 0 & & 0 & & & & \\
\hline 8 & $\begin{array}{l}\text { Luis Carlos Prestes } \\
\text { (Três Lagoas) }\end{array}$ & GN & 131 & Const & 161,165 & 0 & 181 & Jan./08 & 481,17 & Jan./09 & 181,185 & & & & \\
\hline 9 & Mário Covas (Cuiabá) & GN & 6 & Const & 480,00 & 12,02 & 467,98 & & 0 & & 0 & & & & \\
\hline 10 & $\begin{array}{l}\text { Mário Lago (Macaé } \\
\text { Merchant) }\end{array}$ & GN & 254 & Const & 0 & 0 & 0 & Jan./08 & 841,336 & & 0 & & & & \\
\hline 11 & Norte Fluminense 1 & GN & 31 & Const & 380 & 380 & 0 & & 0 & & 0 & & & & \\
\hline 12 & Norte Fluminense 2 & GN & 43 & Const & 95 & 95 & 0 & & 0 & & 0 & & & & \\
\hline 13 & Norte Fluminense 3 & GN & 74 & Const & 190 & 190 & 0 & & 0 & & 0 & & & & \\
\hline 14 & Norte Fluminense 4 & GN & 108 & Const & 81,035 & 80,75 & 0 & & 0 & & 0 & & & & \\
\hline 15 & Piratininga 1 e 2 & GN & 125 & Const & 83,315 & 0 & 83 & Jan./08 & 83,22 & Jan./09 & $-166,54$ & & & & \\
\hline 16 & Piratininga 3 e 4 & GN & 318 & Const & 0 & 0 & 0 & Jul./08 & 152 & Jan./09 & 95 & & & & \\
\hline 17 & Brasília & OD & 1.017 & Const & 9 & 0 & 9 & & & & & & & & \\
\hline 18 & Carioba & OC & 937 & Const & 32,544 & 0 & 33 & & & & & & & & \\
\hline 19 & Goiânia II & OC & 600 & Const & 0 & 0 & 0 & Jan./09 & 126 & & & & & & \\
\hline 20 & Igarapé & OC & 645 & Const & 117,9 & 0 & 118 & & 0 & & & & & & \\
\hline 21 & José Roberto Silveira & $O C$ & 523 & Const & 27 & 0 & 27 & & 0 & & & & & & \\
\hline 22 & Palmeira de Goiás & OC & 601 & Const & 0 & 0 & 0 & Jan./11 & 156,87 & & & & & & \\
\hline 23 & Piratininga 1 e 2 Óleo & OC & 470 & Const & 424,8 & 0 & 425 & Jan./07 & $-78,93$ & Jan./08 & $-78,84$ & Jul./08 & -144 & Jan./09 & 67,77 \\
\hline 24 & Santa Cruz Diesel & OD & 731 & Const & 149,4 & 0 & 149 & & 0 & & & & & & \\
\hline 25 & Santa Cruz Óleo & OC & 310 & Const & 510 & 0 & 540 & & & & & & & & \\
\hline 26 & W. Ariona & $\mathrm{OC}$ & 808 & Const & 185,715 & 0 & 186 & & & & & & & & \\
\hline 27 & & & 0 & Const & & & 0 & & & & & & & & \\
\hline 28 & & & 0 & Const & & & 0 & & & & & & & & \\
\hline 29 & & & 0 & Const & & & 0 & & & & & & & & \\
\hline 30 & & & 0 & Const & & & 0 & & & & & & & & \\
\hline
\end{tabular}




\section{APÊNDICE C.2 - Parque termelétrico atual e expansão - SUL}

\begin{tabular}{|c|c|c|c|c|c|c|c|c|c|c|c|c|c|c|c|}
\hline & \multirow[b]{2}{*}{ Nome do Empreendimento } & \multirow[b]{2}{*}{ Combustível } & \multicolumn{2}{|c|}{ Preço } & \multicolumn{3}{|c|}{ Capacidade (MWmed) } & \multicolumn{2}{|c|}{ Expansão 1} & \multicolumn{2}{|c|}{ Expansão 2} & \multicolumn{2}{|c|}{ Expansão 3} & \multicolumn{2}{|c|}{ Expansão 4} \\
\hline & & & Piso & Evolução & Instalado & Inflexível & Disponível & Data & MWFlex & Data & MWFlex & Data & MWFlex & Data & MWFlex \\
\hline$\overline{1}$ & Candiota III & $\mathrm{CM}$ & 152 & Const & 0 & 0 & 0 & Jan./10 & 315 & & & & & & \\
\hline 2 & Charqueadas & $\mathrm{CM}$ & 143 & Const & 64,8 & 0 & 65 & & & & & & & & \\
\hline 3 & Figueira & $\mathrm{CM}$ & 206 & Const & 78 & 5,85 & 12 & & & & & & & & \\
\hline 4 & J. Lacerda A1 & $\mathrm{CM}$ & 170 & Const & 90 & 0 & 90 & & & & & & & & \\
\hline 5 & J. Lacerda A2 & $\mathrm{CM}$ & 129 & Const & 118,8 & 59,4 & 59 & & & & & & & & \\
\hline 6 & J. Lacerda B & $\mathrm{CM}$ & 129 & Const & 285,6 & 144 & 92 & & & & & & & & \\
\hline 7 & J. Lacerda C & $\mathrm{CM}$ & 105 & Const & 326,7 & 0 & 327 & & & & & & & & \\
\hline 8 & Jacuí & $\mathrm{CM}$ & 152 & Const & 0 & 0 & 0 & & & & & & & & \\
\hline 9 & P. Médici A & $\mathrm{CM}$ & 116 & Const & 113,4 & 0 & 113 & & & & & & & & \\
\hline 10 & P. Médici B & $\mathrm{CM}$ & 116 & Const & 288 & 81 & 207 & & & & & & & & \\
\hline 11 & S. Jerônimo & $\mathrm{CM}$ & 248 & Const & 18 & 5,4 & 13 & & & & & & & & \\
\hline 12 & Araucária & GN & 219 & Const & 435,29 & 0 & 435 & Jan./08 & $-216,79$ & Jul./10 & 216,79 & & & & \\
\hline 13 & Uruguaiana & GN & 139 & Const & 0 & 0 & 0 & & & & & & & & \\
\hline 14 & Alegrete & $\mathrm{OC}$ & 565 & Const & 59,4 & 0 & 59 & & & & & & & & \\
\hline 15 & Nutepa & OC & 780 & Const & 21,6 & 0 & 22 & & & & & & & & \\
\hline 16 & $\begin{array}{l}\text { Sepé Tiaraju (Ex-Canoas) } \\
\text { Óleo }\end{array}$ & OC & 542 & Const & 144,515 & 0 & 145 & Jan./07 & $-68,85$ & Jan./08 & $-68,85$ & & & & \\
\hline 17 & Sepé Tiaraju (Ex-Canoas) & GN & 385 & Const & 72,675 & 0 & 73 & Jan./08 & 72,675 & & & & & & \\
\hline 18 & Incicatva 1 & $\mathrm{CM}$ & 153 & Const & 0 & 0 & 0 & Jan./12 & 990 & & & & & & \\
\hline 19 & Incicativa 2 & $\mathrm{CM}$ & 154 & Const & 0 & 0 & 0 & Jan./16 & 450 & & & & & & \\
\hline
\end{tabular}


APÊNDICE C.3 - Parque termelétrico atual e expansão - NORDESTE

\begin{tabular}{|c|c|c|c|c|c|c|c|c|c|c|c|c|c|c|c|}
\hline & \multirow[b]{2}{*}{$\begin{array}{l}\text { Nome } \\
\text { Empreendimento }\end{array}$} & \multirow[b]{2}{*}{ Combustível } & \multicolumn{2}{|c|}{ Preço } & \multicolumn{3}{|c|}{ Capacidade (MWmed) } & \multicolumn{2}{|c|}{ Expansão 1} & \multicolumn{2}{|c|}{ Expansão 2} & \multicolumn{2}{|c|}{ Expansão 3} & \multicolumn{2}{|c|}{ Expansão 4} \\
\hline & & & Piso & Evolução & Instalado & Inflexível & Disponível & Data & MWFlex & Data & MWFlex & Data & MWFlex & Data & MWFlex \\
\hline 1 & Camaçari (Bahia I) & GN & 231 & Const & 29,45 & 0 & 29 & & & & & & & & \\
\hline 2 & $\begin{array}{l}\text { Senador Carlos Jereissati } \\
\text { (Termoceará) }\end{array}$ & GN & 492 & Const & 0 & 0 & 0 & Jan./08 & 103,36 & Jul./08 & 103,36 & Jan./09 & $-0,57$ & & \\
\hline 3 & Rômulo Almeida (Fafen) & GN & 196 & Const & 118,75 & 0 & 119 & & & & & & & & \\
\hline 4 & Celso Furtado (Termobahia) & GN & 191 & Const & 912 & 0 & 91 & Jul./08 & 51,3 & & & & & & \\
\hline 5 & Fortaleza & GN & 61 & Const & 0 & 0 & 0 & Jan./08 & 155,23 & Jul./06 & 155,135 & & & & \\
\hline 6 & Termopernambuco & GN & 70 & Const & 0 & 0 & 0 & Jan./08 & 169,005 & Jan./09 & 299,82 & & & & \\
\hline 7 & Petrolina Óleo & OC & 471 & Const & 122,58 & 0 & 123 & Jan./07 & $-115,2$ & Jan./09 & 115,2 & & & & \\
\hline 8 & Termocabo Óleo & OC & 472 & Const & 67,3245 & 0 & 67 & Jan./07 & $-43,2$ & & & & & & \\
\hline 9 & Jaguarari & OC & 503 & Const & 91,386 & 0 & 91 & & & & & & & & \\
\hline 10 & Vale do Açu & GN & 131 & Const & 0 & 0 & 0 & Jan./08 & 135,375 & Jul./08 & 135,375 & & & & \\
\hline 11 & Petrolina & GN & 131 & Const & 121,6 & 0 & 122 & Jan./09 & $-121,6$ & & & & & & \\
\hline 12 & Termocabo & GN & 131 & Const & 45,6 & 0 & 46 & & & & & & & & \\
\hline 13 & Leilão 20061 & OC & 500 & Const & 0 & 0 & 0 & Jan./09 & 553,14 & & & & & & \\
\hline 14 & Leilão 20062 & OC & 501 & Const & 0 & 0 & 0 & Jan./09 & 237,06 & & & & & & \\
\hline 15 & Indicativa 1 & GNL & 701 & Const & 0 & 0 & 0 & Jan./11 & 1615 & & & & & & \\
\hline 16 & Indicativa 2 & GNL & 702 & Const & 0 & 0 & 0 & Jan./12 & 665 & & & & & & \\
\hline
\end{tabular}




\section{APÊNDICE C.4 - Parque termelétrico atual e expansão - NORTE}

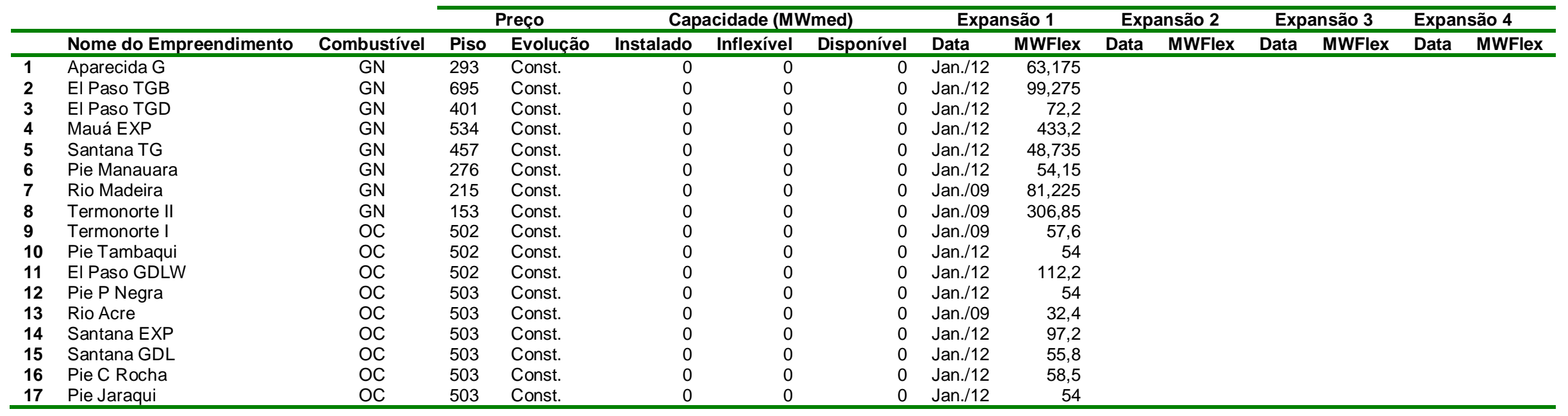




\section{APÊNDICE D.1: Fator de Emissão ( $\left(\mathrm{CO}_{2} / \mathrm{MWh}\right)$, Eficiências da Oferta Térmica Convencional do Sudeste}

\begin{tabular}{|c|c|c|c|c|}
\hline Nome do Empreendimento & Combustível & Tipo & Eficiência & $\mathrm{FE} \mathrm{tCO} / \mathrm{MWh}$ \\
\hline Aureliano Chaves (Ibirité) & GN & Existente & 0,50 & 0,40 \\
\hline Barbosa Lima Sobrinho (Eletrobolt) & GN & Existente & 0,50 & 0,40 \\
\hline Cubatão & GN & Nova & 0,50 & 0,33 \\
\hline Do Atlântico 1 & GN & Nova & 0,50 & 0,33 \\
\hline Fernando Gasparian (N. Piratininga) & GN & Existente & 0,50 & 0,40 \\
\hline Gov. Leonel Brizola (Termorio) & GN & Existente & 0,50 & 0,40 \\
\hline Juiz de Fora & GN & Existente & 0,50 & 0,40 \\
\hline Luis Carlos Prestes (Três Lagoas) & GN & Existente & 0,50 & 0,40 \\
\hline Mário Covas (Cuiabá) & GN & Existente & 0,50 & 0,40 \\
\hline Mário Lago (Macaé Merchant) & GN & Existente & 0,50 & 0,40 \\
\hline Norte Fluminense 1 & GN & Existente & 0,50 & 0,40 \\
\hline Norte Fluminense 2 & GN & Existente & 0,50 & 0,40 \\
\hline Norte Fluminense 3 & GN & Existente & 0,50 & 0,40 \\
\hline Norte Fluminense 4 & GN & Existente & 0,50 & 0,40 \\
\hline Piratininga 1 e 2 & GN & Existente & 0,50 & 0,40 \\
\hline Piratininga 3 e 4 & GN & Existente & 0,50 & 0,40 \\
\hline Brasília & OD & Existente & 0,33 & 0,80 \\
\hline Carioba & OC & Existente & 0,33 & 0,84 \\
\hline Goiânia II & OC & Existente & 0,33 & 0,84 \\
\hline Igarapé & OC & Existente & 0,33 & 0,84 \\
\hline José Roberto Silveira & OC & Existente & 0,33 & 0,84 \\
\hline Palmeira de Goiás & OC & Nova & 0,46 & 0,60 \\
\hline Piratininga 1 e 2 Óleo & OC & Existente & 0,33 & 0,84 \\
\hline Santa Cruz Diesel & OD & Existente & 0,33 & 0,80 \\
\hline Santa Cruz Óleo & OC & Existente & 0,33 & 0,84 \\
\hline W. Ariona & OC & Nova & 0,46 & 0,60 \\
\hline Quirinópolis (2008) & BM & Nova & & 0,00 \\
\hline Interlagos (2008) & BM & Nova & & 0,00 \\
\hline PIE - RP (2008) & BM & Nova & & 0,00 \\
\hline Cocal (2008) & BM & Nova & & 0,00 \\
\hline Daia & $\mathrm{OC}$ & Nova & & 0,60 \\
\hline Xavante Aruanã (2008) & OC & Nova & 0,46 & 0,60 \\
\hline Interlagos (2009) & BM & Nova & & 0,00 \\
\hline PIE - RP (2009) & BM & Nova & & 0,00 \\
\hline Cocal (2009) & BM & Nova & & 0,00 \\
\hline São João Biogás & BM & Nova & & 0,00 \\
\hline Quirinópolis (2009) & BM & Nova & & 0,00 \\
\hline São José & BM & Nova & & 0,00 \\
\hline Colorado & BM & Nova & & 0,00 \\
\hline Santa Isabel & BM & Nova & & 0,00 \\
\hline Rafard & BM & Nova & & 0,00 \\
\hline Costa Pinto e Lasa & BM & Nova & & 0,00 \\
\hline Viana & OC & Nova & 0,46 & 0,60 \\
\hline São João da Boa Vista & BM & Nova & & 0,00 \\
\hline Santa Cruz AB Fase 1 e 2 & BM & Nova & & 0,00 \\
\hline Ester & BM & Nova & & 0,00 \\
\hline lacanga & BM & Nova & & 0,00 \\
\hline Conjunto Altern 2010 & BM & Nova & & 0,00 \\
\hline Linhares & GNL & Nova & 0,40 & 0,33 \\
\hline Boa Vista & BM & Nova & & 0,00 \\
\hline Quata & BM & Nova & & 0,00 \\
\hline Usina Bonfim & BM & Nova & & 0,00 \\
\hline Ferrari & BM & Nova & & 0,00 \\
\hline Escolha & GNL & Nova & 0,40 & 0,33 \\
\hline Parauna & BM & Nova & & 0,00 \\
\hline Cacimbaes & GNL & Nova & 0,40 & 0,33 \\
\hline MC2 Joinville e João Neiva & GNL & Nova & 0,40 & 0,33 \\
\hline Conjunto Leilão 7 & $O C$ & Nova & 0,46 & 0,60 \\
\hline
\end{tabular}




\section{APÊNDICE D.2: Fator de Emissão (tCO $/ \mathrm{MWh}_{2}$ e Eficiências da Oferta Térmica Convencional do Sul}

\begin{tabular}{lclcc}
\hline Nome do Empreendimento & Combustível & Tipo & Eficiência & FE tCO $\mathbf{~} \mathbf{M W h}$ \\
\hline Candiota III & CM & Nova & 0,46 & 0,68 \\
Charqueadas & CM & Existente & 0,33 & 1,03 \\
Figueira & CM & Existente & 0,33 & 1,03 \\
J. Lacerda A1 & CM & Existente & 0,33 & 1,03 \\
J. Lacerda A2 & CM & Existente & 0,33 & 1,03 \\
J. Lacerda B & CM & Existente & 0,33 & 1,03 \\
J. Lacerda C & CM & Existente & 0,33 & 1,03 \\
Jacuí & CM & Nova & 0,50 & 0,68 \\
P. Médici A & CM & Existente & 0,33 & 1,03 \\
P. Médici B & CM & Existente & 0,33 & 1,03 \\
S. Jerônimo & CM & Existente & 0,33 & 1,03 \\
Araucária & GN & Existente & 0,50 & 0,40 \\
Uruguaiana & GN & Existente & 0,50 & 0,40 \\
Alegrete & OC & Existente & 0,33 & 0,84 \\
Nutepa & OC & Existente & 0,33 & 0,84 \\
Sepé Tiaraju (Ex-Canoas) Ooleo & OC & Existente & 0,33 & 0,84 \\
Sepé Tiaraju (Ex-Canoas) & GN & Existente & 0,50 & 0,40 \\
Cisframa & OC & Nova & 0,46 & 0,60 \\
Xanxere & BM & Nova & & 0,00 \\
\hline
\end{tabular}




\section{APÊNDICE D.3: Fator de Emissão ( $\left.\mathrm{tCO}_{2} / \mathrm{MWh}\right)$ e Eficiências da Oferta Térmica Convencional do Nordeste}

\begin{tabular}{|c|c|c|c|c|}
\hline Nome do Empreendimento & Combustível & Tipo & Eficiência & $\begin{array}{c}\mathrm{FE} \\
\mathrm{tCO}_{2} / \mathrm{MWh}\end{array}$ \\
\hline Camaçari (Bahia I) & GN & Existente & 0,50 & 0,40 \\
\hline Senador Carlos Jereissati & & & & \\
\hline (Termoceará) & GN & Existente & 0,50 & 0,40 \\
\hline Rômulo Almeida (Fafen) & GN & Existente & 0,50 & 0,40 \\
\hline Celso Furtado (Termobahia) & GN & Existente & 0,50 & 0,40 \\
\hline Fortaleza & GN & Existente & 0,50 & 0,40 \\
\hline Termopernambuco & GN & Existente & 0,50 & 0,40 \\
\hline Petrolina Óleo & $\mathrm{OC}$ & Existente & 0,33 & 0,84 \\
\hline Termocabo Óleo & OC & Existente & 0,33 & 0,84 \\
\hline Jaguarari & $\mathrm{OC}$ & Existente & 0,33 & 0,84 \\
\hline Vale do Açu & GN & Existente & 0,50 & 0,40 \\
\hline Petrolina & GN & Existente & 0,50 & 0,40 \\
\hline Termocabo & GN & Existente & 0,50 & 0,40 \\
\hline MC2 Dias Davila 2 & $\mathrm{OC}$ & Nova & 0,46 & 0,60 \\
\hline MC2Camaçari 1 & $\mathrm{OC}$ & Nova & 0,46 & 0,60 \\
\hline MPX & $\mathrm{CM}$ & Nova & 0,46 & 0,68 \\
\hline MC2 Dias Davila 1 & $\mathrm{OC}$ & Nova & 0,46 & 0,60 \\
\hline MC2 Catu & $\mathrm{OC}$ & Nova & 0,46 & 0,60 \\
\hline MC2 Senhor do Bonfim & $\mathrm{OC}$ & Nova & 0,46 & 0,60 \\
\hline MC2 Feira de Santana & OC & Nova & 0,46 & 0,60 \\
\hline Santa Rita de Cássia & $\mathrm{OC}$ & Nova & 0,46 & 0,60 \\
\hline Maracanau II & OC & Nova & 0,46 & 0,60 \\
\hline Pernambuco IV & $\mathrm{OC}$ & Nova & 0,46 & 0,60 \\
\hline José de Alencar & GNL & Nova & 0,40 & 0,33 \\
\hline Suape II & $\mathrm{OC}$ & Nova & 0,46 & 0,60 \\
\hline Monte Pascoal & $\mathrm{OC}$ & Nova & 0,46 & 0,60 \\
\hline Campina Grande & OC & Nova & 0,46 & 0,60 \\
\hline Maracanau I & $\mathrm{OC}$ & Nova & 0,46 & 0,60 \\
\hline Itapebi & OC & Nova & 0,46 & 0,60 \\
\hline Pecem II & $\mathrm{OC}$ & Nova & 0,46 & 0,60 \\
\hline Potiguar I e III & OC & Nova & 0,46 & 0,60 \\
\hline Camaçari Pólo de Apoio I & OC & Nova & 0,46 & 0,60 \\
\hline Pau Ferro I e Termomanaus & OC & Nova & 0,46 & 0,60 \\
\hline Camaçari Muciry II & $\mathrm{OC}$ & Nova & 0,46 & 0,60 \\
\hline Camaçari Muricy I & OC & Nova & 0,46 & 0,60 \\
\hline Global I e II & $\mathrm{OC}$ & Nova & 0,46 & 0,60 \\
\hline Termoparaiba & $\mathrm{OC}$ & Nova & 0,46 & 0,60 \\
\hline Termonordeste & OC & Nova & 0,46 & 0,60 \\
\hline Baia Formosa & BM & Nova & & 0,00 \\
\hline Bahia I & OC & Nova & 0,46 & 0,60 \\
\hline Leilão 2005 & $\mathrm{OC}$ & Nova & 0,46 & 0,60 \\
\hline Porto do Pecem II & $\mathrm{CM}$ & Nova & 0,50 & 0,68 \\
\hline Pernambuco III & $\mathrm{OC}$ & Nova & 0,46 & 0,60 \\
\hline Termopower VI & OC & Nova & 0,46 & 0,60 \\
\hline Termopower V & $\mathrm{OC}$ & Nova & 0,46 & 0,60 \\
\hline MC2 Camaçari 3 & OC & Nova & 0,46 & 0,60 \\
\hline MC2 Camaçari 2 & OC & Nova & 0,46 & 0,60 \\
\hline MC2 Santo Antonio de Jesus & $\mathrm{OC}$ & Nova & 0,46 & 0,60 \\
\hline Conj Leilão 7 & OC & Nova & 0,46 & 0,60 \\
\hline
\end{tabular}


APÊNDICE D.4: Fator de Emissão ( $\mathrm{tCO}_{2} / \mathrm{MWh}$ ) e Eficiências da Oferta Térmica Convencional do Norte

\begin{tabular}{lcccc}
\hline Nome do Empreendimento & Combustível & Tipo & Eficiência & FE tCO $\mathbf{~} \mathbf{M W h}$ \\
\hline Aparecida G & GN & Existente & 0,40 & 0,40 \\
El Paso TGB & GN & Existente & 0,40 & 0,40 \\
El Paso TGD & GN & Existente & 0,40 & 0,40 \\
Mauá EXP & GN & Existente & 0,40 & 0,40 \\
Santana TG & GN & Existente & 0,40 & 0,40 \\
Pie Manauara & GN & Existente & 0,40 & 0,40 \\
Rio Madeira & GN & Existente & 0,40 & 0,40 \\
Termonorte II & GN & Existente & 0,40 & 0,40 \\
Termonorte I & OC & Existente & 0,33 & 0,84 \\
Pie Tambaqui & OC & Existente & 0,33 & 0,84 \\
El Paso GDLW & OC & Existente & 0,33 & 0,84 \\
Pie P Negra & OC & Existente & 0,33 & 0,84 \\
Rio Acre & OC & Existente & 0,33 & 0,84 \\
Santana EXP & OC & Existente & 0,33 & 0,84 \\
Santana GDL & OC & Existente & 0,33 & 0,84 \\
Pie C Rocha & OC & Existente & 0,33 & 0,84 \\
Pie Jaraqui & OC & Existente & 0,33 & 0,84 \\
Termomaranhão & CM & Nova & 0,50 & 0,68 \\
Nova Olinda & OC & Nova & 0,46 & 0,60 \\
Tocantinópolis & OC & Nova & 0,46 & 0,60 \\
\hline
\end{tabular}




\section{ANEXO A - Quadro SPF 1}

\section{Quadro SPF 1: Os cenários de emissões do Relatório Especial sobre Cenários de Emissões (RECE) do IPCC}

A1. O contexto e a família de cenários $A 1$ descrevem um mundo futuro de crescimento econômico muito rápido, com a população global atingindo um pico em meados do século e declinando em seguida e a rápida introdução de tecnologias novas e mais eficientes. As principais questões subjacentes são a convergência entre as regiões, a capacitação e o aumento das interações culturais e sociais, com uma redução substancial das diferenças regionais na renda per capita. A família de cenários A1 se desdobra em três grupos que descrevem direções alternativas da mudança tecnológica no sistema energético. Os três grupos A1 distinguem-se por sua ênfase tecnológica: intensiva no uso de combustíveis fósseis $(\mathrm{A} 1 \mathrm{Fl})$, fontes energéticas não-fósseis $(\mathrm{A} 1 \mathrm{~T})$ ou um equilíbrio entre todas as fontes (A1B) (em que o equilíbrio é definido como uma dependência não muito forte de uma determinada fonte de energia, supondo-se que taxas similares de aperfeiçoamento apliquem-se a todas as tecnologias de oferta de energia e uso final).

A2. O contexto e a família de cenários $A 2$ descrevem um mundo muito heterogêneo. $O$ tema subjacente é a auto-suficiência e a preservação das identidades locais. Os padrões de fertilidade entre as regiões convergem muito lentamente, o que acarreta um aumento crescente da população. O desenvolvimento econômico é orientado primeiramente para a região e o crescimento econômico per capita e a mudança tecnológica são mais fragmentados e mais lentos do que nos outros contextos.

B1. O contexto e a família de cenários B1 descrevem um mundo convergente com a mesma população global, que atinge o pico em meados do século e declina em seguida, como no contexto $A 1$, mas com uma mudança rápida nas estruturas econômicas em direção a uma economia de serviços e informações, com reduções da intensidade material e a introdução de tecnologias limpas e eficientes em relação ao uso dos recursos. A ênfase está nas soluções globais para a sustentabilidade econômica, social e ambiental, inclusive a melhoria da eqüidade, mas sem iniciativas adicionais relacionadas com o clima. B2. O contexto e família de cenários B2 descrevem um mundo em que a ênfase está nas soluções locais para a sustentabilidade econômica, social e ambiental. É um mundo em que a população global aumenta continuamente, a uma taxa inferior à do A2, com níveis intermediários de desenvolvimento econômico e mudança tecnológica menos rápida e mais diversa do que nos contextos $\mathrm{B} 1$ e $\mathrm{A} 1$. O cenário também está orientado para a proteção ambiental e a eqüidade social, mas seu foco é o nível local e regional.

Um cenário ilustrativo foi escolhido para cada um dos seis grupos de cenários $\mathrm{A} 1 \mathrm{~B}, \mathrm{~A} 1 \mathrm{FI}$, A1T, A2, B1 e B2. Todos devem ser considerados igualmente consistentes.

Fonte: IPCC, 2007 - Texto traduzido pelo MCT 


\section{ANEXO B - Nota de Esclarecimento da CIMGC}

Ministério da Ciência e Tecnologia - MCT Comissão Interministerial de Mudança Global do Clima - CIMGC

\section{NOTA DE ESCLARECIMENTO}

\section{OBJETIVO:}

Informar aos interessados sobre a decisão da Comissão Interministerial de Mudança Global do Clima - CIMGC sobre os fatores de emissão de CO2 para o Sistema Interligado Nacional - SIN a serem adotados nos projetos de MDL no Brasil. Visa, também, informar sobre os fundamentos técnicos que embasaram a decisão tomada, assim como o cronograma previsto para a sua implementação.

\section{CONTEXTO:}

Foi formado, em julho de 2005, um grupo de trabalho constituído pelo Ministério de Minas e Energia - MME e Ministério de Ciência e Tecnologia MCT, com a participação do Operador Nacional do Sistema Elétrico - ONS, a fim de disponibilizar aos proponentes de projetos no âmbito do MDL as informações necessárias à aplicação da metodologia ACM0002. De acordo com a versão 6 desta metodologia, vigente à época, o método de análise pelo despacho foi indicado como o mais adequado para cálculo dos fatores de emissão, mas exigia informações horárias detalhadas sobre a energia despachada por subsistema.

O MME, O MCT e o ONS trabalharam para adequar essa metodologia às condições particulares do sistema elétrico brasileiro. De forma a garantir a transparência do processo, o detalhamento dos critérios adotados na aplicação da metodologia ao Brasil foi amplamente divulgado na página do MCT na internet (http://www.mct.gov.br/index.php/content/view/50862.html). Também foram realizadas duas reuniões com especialistas e partes interessadas no 
desenvolvimento de projetos, uma no Rio de Janeiro no dia 20 de março de 2007, antes da divulgação dos resultados, e outra em Brasília no dia 16 de agosto de 2007, quando os critérios foram discutidos. A questão que mais mobilizou os proponentes do projeto não se referia propriamente à adaptação da metodologia, mas sim, à definição do número de subsistemas do SIN.

O grupo de trabalho, após discussão das questões relevantes, propôs a adoção de quatro subsistemas, seguindo a subdivisão Norte, Nordeste, Sudeste/Centro-Oeste e Sul adotada pelo ONS no despacho do SIN. Os fatores de emissão de $\mathrm{CO} 2$ passaram a ser calculados sistematicamente pelo ONS a partir de janeiro de 2006 e divulgados na página da CIMGC. Concomitantemente, a CIMGC enviou ao Conselho Executivo do MDL, para consideração, uma descrição detalhada de como a metodologia ACM0002 havia sido aplicada ao caso brasileiro.

A estrutura de quatro subsistemas, então adotada, diferia da estrutura adotada por grande parte dos projetos já submetidos à CIMGC, que consideravam apenas dois subsistemas (Norte/Nordeste e Sul/Sudeste/Centro-Oeste).

Com objetivo de ampliar a discussão, a CIMGC realizou Consulta Pública, no período de 7 de dezembro de 2007 a 31 de janeiro de 2008, solicitando comentários sobre os critérios adotados para a aplicação da metodologia ACM0002 no Brasil. Como resultado, foram recebidas 21 submissões de diversas instituições envolvidas com o tema. As contribuições levantaram críticas, principalmente, à estrutura de quatro subsistemas (questionada em todas as submissões). A adoção de quatro subsistemas foi defendida em apenas uma contribuição; as demais optaram ou pela adoção de dois subsistemas ou de um sistema único. Outras questões abordadas versaram sobre a viabilização de projetos de energia renovável em diferentes regiões, a adequação da metodologia ACM0002 ao SIN, e possíveis definições sobre restrição de transmissão no contexto do $\mathrm{MDL}$, entre outras. Ministério da Ciência e Tecnologia - MCT Comissão Interministerial de Mudança Global do Clima - CIMGC

\section{ANÁLISE DOS RESULTADOS DA CONSULTA PÚBLICA:}

Assim sendo, foi realizada no dia 25 de fevereiro de 2008 , a primeira reunião do Grupo de Trabalho para avaliação das submissões. Tendo em vista que o 
foco dos questionamentos foi a estrutura dos subsistemas, a análise recaiu sobre as alternativas enumeradas, as quais podem ser concentradas em:

1) Quatro subsistemas: Norte; Nordeste; Sudeste/Centro-Oeste; Sul.

2) Dois subsistemas: Norte/Nordeste; Sul/Sudeste/Centro-Oeste.

3) Sistema único.

Deve-se ressaltar que, durante o período de Consulta Pública, foi aprovada, pelo Conselho Executivo do Mecanismo de Desenvolvimento Limpo, em Bonn, Alemanha, nova versão ( $n^{\circ}$ 7) da metodologia ACM0002, a qual remete a uma ferramenta metodológica específica para o cálculo do fator de emissão de sistemas elétricos. Esta ferramenta, especificamente sobre o número de subsistemas de uma rede elétrica, apresentou dois critérios que poderiam ser utilizados para a identificação de restrições significativas de transmissão entre dois subsistemas. Cabe observar que esses critérios, transcritos a seguir, não são nem obrigatórios nem complementares, mas tão somente possíveis critérios para se identificar restrições significativas de transmissão, conforme sugerido na ferramenta metodológica:

a) No caso de sistemas elétricos com mercados "spot", quando houver diferenças nos preços de eletricidade (sem custos de transmissão e distribuição) de mais de $5 \%$ entre os sistemas durante $60 \%$ ou mais das horas do ano.

b) Quando a linha de transmissão operar a $90 \%$ ou mais que sua capacidade plena durante $90 \%$ ou mais das horas do ano.

O Grupo de Trabalho partiu da alternativa (1), configuração de quatro subsistemas (Norte; Nordeste; Sudeste/Centro-Oeste; Sul), para verificar a possibilidade da alternativa (2), por meio da análise de eventuais restrições de transmissão entre Norte e Nordeste, por um lado, e entre Sul e Sudeste/Centro-Oeste, por outro, segundo os critérios propostos (a) e (b). As simulações foram realizadas pelo ONS e passaram por avaliação dos demais membros do Grupo de Trabalho. A conclusão nesta etapa foi de que não havia restrições de transmissão entre Sul e Sudeste/Centro-Oeste, como também não havia entre Norte e Nordeste. 
Em seguida, foi feita uma análise para verificar se existiam restrições de transmissão entre os dois subsistemas (Norte/Nordeste; Sul/Sudeste/CentroOeste). Com relação ao critério (a), foram analisadas opções mais ou menos conservadoras de realização dos cálculos, como por exemplo, a inclusão ou não do submercado Sul no cálculo das diferenças percentuais de preços. Por meio de análise de sensibilidade, mostrou-se que, de acordo com critérios mais voltados para a realidade da operação do SIN, a percentagem de tempo em que os preços se diferenciaram em mais de $5 \%$, seria de $60 \%$, o que estaria no limite sugerido na ferramenta de cálculo, não havendo, portanto, restrições significativas de transmissão. Em relação ao critério (b) (saturação da linha), não se comparou o fluxo entre os subsistemas com a capacidade plena da transmissão entre os subsistemas, por ser este um procedimento complexo, o qual depende das configurações do sistema de interligação que foram verificadas durante a operação e dos sentidos dos fluxos entre regiões. Utilizou-se, portanto, uma análise mais simples que consistiu em verificar o comportamento da diferença de preços entre regiões. Considerou-se que essa análise simplificada é conservadora, no sentido de que pode incluir restrições além da capacidade plena da linha citada na ferramenta do Conselho Executivo. As simulações apontaram que em apenas $70 \%$ das horas do ano houve transmissão durante $90 \%$ ou mais da capacidade plena, indicando também a não existência de restrições significativas de transmissão. Dispensou-se, assim, uma análise detalhada do fluxo entre os sistemas ao longo do tempo.

\section{CONCLUSÕES E CONSIDERAÇÕES DO GRUPO DE TRABALHO MME, MCT e ONS:}

O Grupo de Trabalho, reunido em 28 de abril de 2008, no MME, analisou os resultados das simulações realizadas.

Foi consenso entre os membros do Grupo que as restrições de transmissão existentes atualmente entre os submercados do SIN não são suficientes para diminuir substancialmente o benefício global do projeto, em função da região em que seja implantado, sendo, portanto, recomendável que se adote a configuração de um único sistema elétrico no Brasil. 
Ressaltou-se que a adoção desta configuração será válida apenas para efeitos de cálculo dos fatores de emissão de $\mathrm{CO} 2$ em projetos de MDL que utilizem a metodologia ACM0002 para estimar suas reduções de emissão de gases de efeito estufa. Em nenhum momento esta decisão deverá afetar a atual configuração utilizada pelo ONS para o planejamento e a programação da operação, bem como a contabilização de energia e definição de preços realizada pela Câmara de Comercialização de Energia Elétrica - CCEE, a qual adota a subdivisão do SIN em quatro subsistemas. Ressaltou-se que o respaldo técnico fornecido pelas simulações realizadas é que permite que sejam feitas abordagens diferentes, em cada um dos casos.

Por fim, destacou-se que o processo de evolução do SIN apenas deverá confirmar a decisão de se adotar um único sistema para o cálculo do fator de emissão de $\mathrm{CO} 2$, uma vez que a ampliação dos reforços da transmissão de energia elétrica entre os subsistemas promoverá diminuições progressivas nas restrições de transmissão, e permitirá que um projeto implantado em um determinado subsistema produza benefícios nos demais subsistemas do SIN.

\section{DECISÃO DA CIMGC:}

A CIMGC, em sua 43를 Reunião, no dia 29 de abril de 2008, após análise dos resultados do Grupo de Trabalho, decidiu pela adoção de um ÚNICO SISTEMA como padrão para projetos de MDL que utilizem a ferramenta de cálculo dos fatores de emissão associada à metodologia ACM0002 para estimar suas reduções de emissão de gases de efeito estufa.

Assim, apresenta-se o seguinte cronograma para a efetiva adoção e publicação dos fatores de emissão do SIN, considerando um sistema único:

- Publicação desta nota de esclarecimento na página da Coordenação-Geral de Mudanças Globais de Clima - CGMC na internet;

- Realização de reunião extraordinária da CIMGC, prevista para o dia 27 de maio de 2008, na qual deverá ser aprovada nova Resolução, adotando-se a definição de um único sistema para fins de projetos de MDL; 
- Publicação, na página do MCT na internet, tão logo a Resolução acima referida seja publicada no Diário Oficial da União, dos fatores de emissão calculados para o sistema único, para os anos de 2006 e 2007 e para os meses de janeiro e fevereiro de 2008.

Os fatores de emissão para o ano de 2005 serão publicados posteriormente. 


\section{ANEXO C - Resolução de no 8, de 26 de maio de 2008}

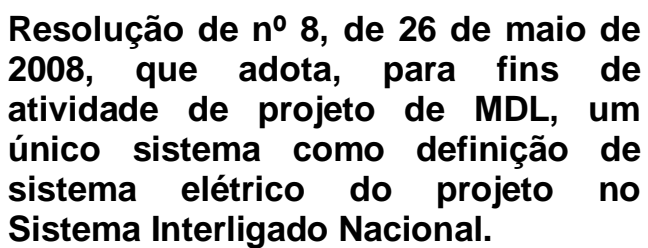

Resolução de no 8, de 26 de maio de 2008, que adota, para fins de atividade de projeto de MDL, um único sistema como definição de Sistema Interligado Nacional.

A Comissão Interministerial de Mudança Global do Clima, criada pelo Decreto de 7 de julho de 1999, no uso de suas atribuições conforme o artigo $3^{\circ}$, incisos III e IV,

Considerando as conclusões do Grupo de Trabalho criado em 2005 e formado pelo Ministério de Minas e Energia e pelo Ministério da Ciência e Tecnologia e com a participação do Operador Nacional do Sistema Elétrico, com a finalidade de disponibilizar aos proponentes de atividades de projeto no Brasil no âmbito do Mecanismo de Desenvolvimento Limpo (MDL) as informações necessárias à adequada aplicação da metodologia ACM0002 aprovada pelo Conselho Executivo do Mecanismo de Desenvolvimento Limpo,

Considerando os resultados da Consulta Pública realizada pela Comissão Interministerial de Mudança Global do Clima, de 7 de dezembro de 2007 a 31 de janeiro de 2008, sobre os critérios necessários à adequada aplicação da metodologia ACM0002 no Brasil,

Considerando a decisão da Comissão Interministerial de Mudança Global do Clima adotada em sua reunião do dia 29 de abril de 2008 sobre o assunto objeto desta Resolução e publicada por meio de Nota de Esclarecimento no sítio internet da Comissão,

RESOLVE:

Art. $1^{\circ}$ - Adotar o sistema único formado pela união dos sub-mercados do Sistema Interligado Nacional (SIN) como definição do "Sistema Elétrico do Projeto" para qualquer atividade de projeto no âmbito do Mecanismo de Desenvolvimento Limpo (MDL) conectada ao SIN, fornecendo ou utilizando energia elétrica da rede, e aplicando as metodologias ACM0002 e AMS-I.D. e/ou a "Ferramenta para calcular o fator de emissão para um sistema elétrico" aprovadas pelo Conselho Executivo do MDL. 
$\S$ único - Esta definição, quando aplicável, deverá ser estendida a quaisquer outras metodologias que tratem de atividades de projeto que se conectem à rede, que venham a ser aprovadas pelo Conselho Executivo do MDL, salvo deliberação expressa em contrário desta Comissão.

Art. 2ㅇ - Publicar regularmente os fatores de emissão, em t $\mathrm{CO} 2$ / MWh, calculados para o sistema único e disponibilizados por mês, dia e hora no sítio internet da Comissão Interministerial de Mudança Global do Clima.

Art. 3o - Esta Resolução entra em vigor na data da sua publicação.

SERGIO MACHADO REZENDE

Presidente da Comissão 